SIDDHARTHA BAVISKAR

CAMILLA BRØRUP DYSSEGAARD

NIELS EGELUND

CHRISTOPHER DE MONTGOMERY

DOKUMM NTEATIONSPROJEKTET:

KOMMUNERNES

OMISILLING

TILIOEET INIKLUSION

PR MARTS 2015. 

Siddhartha Baviskar, Camilla Brørup Dyssegaard, Niels Egelund og Christopher de Montgomery

\title{
Dokumentationsprojektet: Kommunernes omstilling til øget inklusion pr. marts 2015
}

\author{
DPU, Aarhus Universitet \\ SFI - Det Nationale Forskningscenter for Velfærd
}


Titel:

Dokumentationsprojektet: Kommunernes omstilling til øget inklusion pr. marts 2015

Forfattere:

Siddhartha Baviskar, Camilla Brørup Dyssegaard, Niels Egelund

og Christopher de Montgomery

Udgivet af:

DPU Aarhus Universitet, 2015

Copyright: forfatterne

1.udgave

Kopiering tilladt med tydelig kildeangivelse

Omslag og grafisk tilrettelæggelse:

Knud Holt Nielsen

Forsidefoto:

Colourbox

ISBN:

978-87-7684-768-5 (elektronisk udgave)

978-87-7684-769-2 (trykt udgave) 


\section{Forord}

Denne rapport er den afsluttende redegørelse for status på inklusionsprocessen i tolv danske kommuner pr. marts 2015. Den samlede undersøgelse, der går under navnet 'Dokumentationsprojektet', har løbet over årene 2013-2015 og blev givet til et konsortium bestående af Aarhus Universitet og SFI den 16. januar 2013.

Rapporten er udarbejdet af seniorforsker Siddhartha Baviskar, SFI, videnskabelig assistent Christopher de Montgomery, SFI, lektor Camilla Brørup Dyssegaard, AU og professor Niels Egelund, AU. Niels Egelund er projektleder.

Ud over forfatterne til denne rapport har studentermedhjælperne Thomas Aarup Due og Tróndur Møller Sandoy, SFI, bistået med at udarbejde tabeller. Der skal i den forbindelse gøres opmærksom på, at der i denne rapport henvises til diverse bilag, som findes i et selvstændigt elektronisk appendiks, der findes på hjemmesiden for Ministeriet for Børn, Undervisning og Ligestilling.

Sidst, men ikke mindst, skal lyde en tak til de medvirkende skolechefer, PPRledere, skoleledere, skolebestyrelsesformænd, lærere, elever og forældre, der har leveret særdeles nyttige informationer for undersøgelsen.

Niels Egelund

Juni 2015

Projektleder 



\section{Indhold}

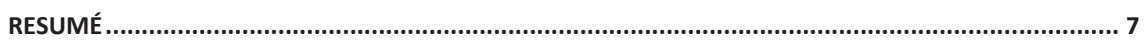

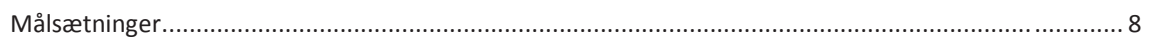

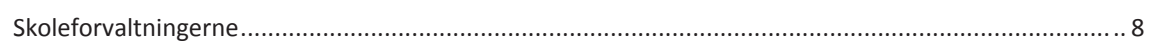

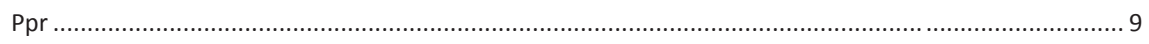

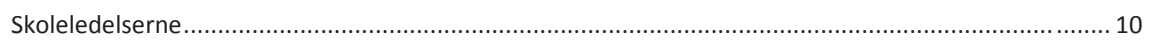

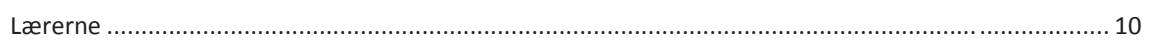

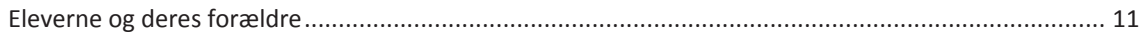

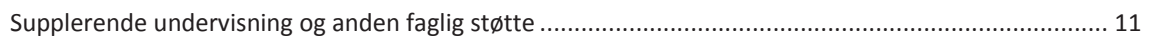

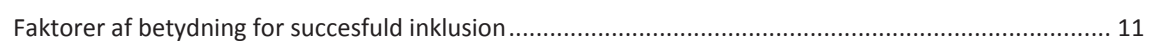

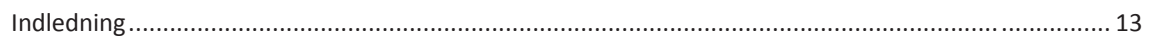

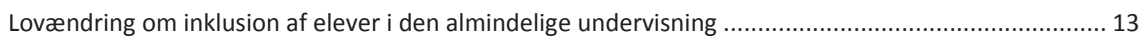

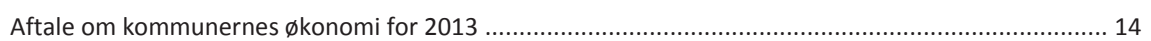

Opfølgning på aftalen om dokumentation af kommunernes omstilling ............................................. 15

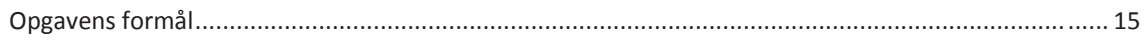

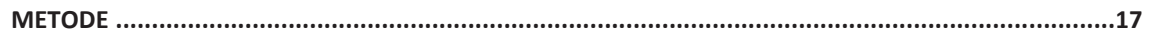

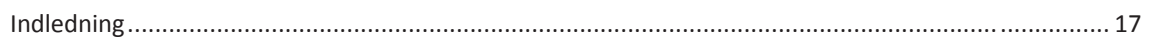

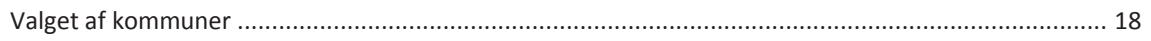

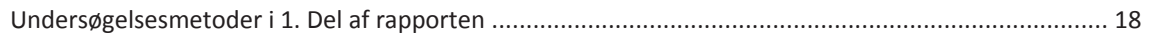

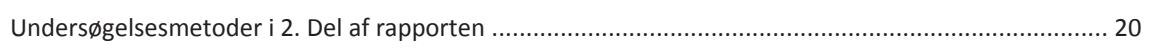

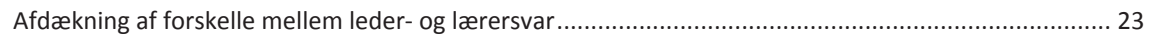

DEL 1. DATA FRA SKOLECHEFER, PPR-LEDERE OG SKOLEFORVALTNINGER ....................................24

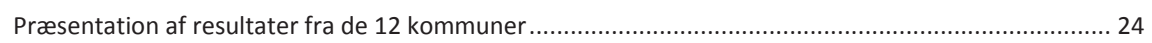

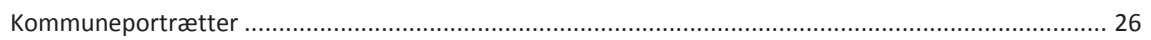

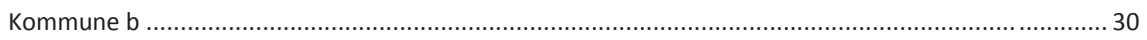

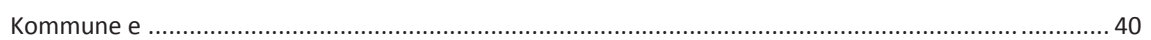

Kvantitative resultater på baggrund af oplysninger fra skoleforvaltningerne og danmarks statistik........ 68

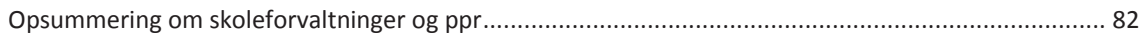

Kvantitative resultater fra interview med skolechefer og ppr-ledere i de 12 kommuner ......................84

Sammenfatning, del 1, skolechefer, ppr og skoleforvaltninger........................................................ 100

DEL 2. DATA FRA SKOLELEDERE, SKOLEBESTYRELSESFORMAEND, LAERERE, ELEVER OG FORAELDE ....105 
Kvantitative resultater fra spørgeskemaundersøgelser og dcum's trivselsmåling blandt elever 105

Analyseresultater for de fem fokuspunkter:.....

Sammenfatning af kvantitative svar fra: skoleledere, skolebestyrelsesformænd, lærere, elever og forældre

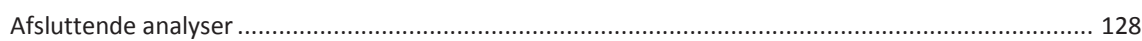

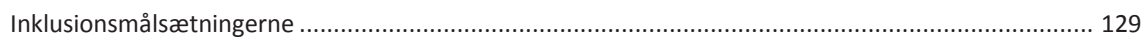

Forskelle og ligheder mellem skoleledere og læreres holdning til inklusion .................................... 131

Hvad har haft betydning for inklusionsprocessen fra 2013 til 2015? ................................................ 137

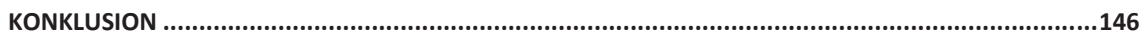

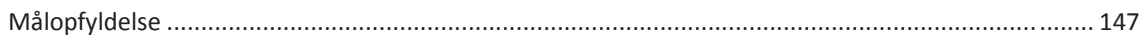

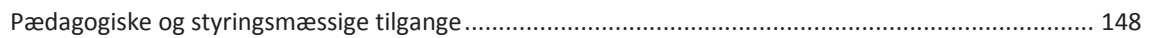

Fokuspunkter for arbejdet med inklusion og inklusionsindikatorer.................................................. 154

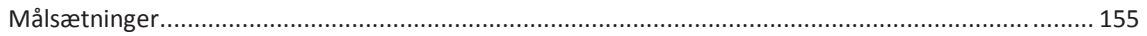

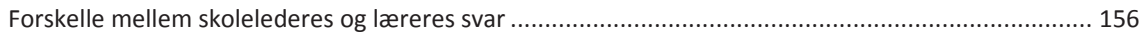

Faktorer der fremmer og hæmmer inklusion .......................................................................... 157

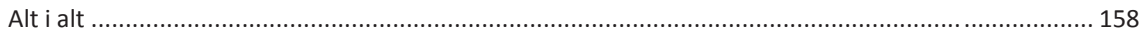

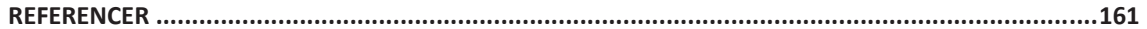




\section{Resumé}

I 2012 blev der mellem regeringen og KL truffet en aftale om konkrete målsætninger for en succesfuld omstilling til inklusion. Målsætningerne omfatter andelen af elever, der inkluderes i den almindelige undervisning, det faglige niveau og elevernes trivsel. Målsætningerne skal være opfyldt i 2015.

Andelen af elever, der skal være inkluderet i 2015, blev sat til et gennemsnit på landsplan på 96 pct. Andelen af elever, der får karakteren 2 eller derunder i læsning, retskrivning og matematisk problemløsning i 9. klasses afgangsprøve, skal være reduceret i 2015 og reduceres yderligere frem mod 2018. Elevernes trivsel skal fastholdes i takt med omstillingen til øget inklusion.

Det indgik i aftalen fra 2012, at der skulle gennemføres en tilbagevendende repræsentativ undersøgelse i 10-12 udvalgte kommuner, og at der skulle ske en årlig afrapportering af status på omstillingen til øget inklusion over foreløbig tre år. Data om supplerende undervisning skal indgå i undersøgelsen.

Dette er den afsluttende rapport om inklusionsprocessen i Danmark i 12 kommuner Undersøgelsen, der betegnes som Dokumentationsprojektet, blev første gang foretaget i 2013, anden undersøgelse er foretaget i 2014, og den sidste og afsluttende undersøgelse skete i starten af 2015. De årligt tilbagevendende rapporter indeholder alle en kortlægning af kommunernes omstillingsproces til en øget inklusion samt en beskrivelse af udviklingen i de landsdækkende registerdata i 12 kommuner. Denne afsluttende rapport dækker udviklingen over hele perioden.

Generelt gælder, at de 12 kommuner, der indgår i Dokumentationsprojektet, dækker et bredt spektrum af den samlede demografiske og økonomiske variation, der findes i danske kommuner. Kommunerne havde i skoleåret 2009/10 endvidere en meget forskellig inklusionsgrad, og der er ikke overraskende store forskelle i den måde, hvorpå man har grebet inklusionsprocessen an. Selve arbejdet med at starte en inklusionsproces strækker sig fra 2011 for de tidligste kommuner, et år før lovændringen i august 2012, over 2012 og til 2013, hvor de sidste kommuner kom i gang for alvor.

I det følgende samles resultaterne fra de forskellige dele af Dokumentationsprojektet under overskriften målopfyldelse, hvor der ses på de konkrete mål for succesfuld inklusion, og derpå overskrifter, som dækker processen, skoleforvaltningerne, PPR, skoleledelserne, lærerne, eleverne og deres forældre og supplerende undervisning og anden faglig støtte. Til sidst ses på, hvad der vurderes at have haft særlig betydning i forhold til resultaterne. 


\section{Målsætninger}

Der gælder følgende om de konkrete målsætninger for en succesfuld inklusion:

- Målet om en gennemsnitlig inklusionsprocent på 96 i 2015 er nået i de 12 kommuner

- Andelen, som får under 2 i dansk er fra 1. til 3. runde øget i 11 kommuner og uændret $i$ en kommune

- Andelen, som får under 2 i matematik, er faldet i otte kommuner, uændret i en kommune og øget i tre kommuner

- Trivslen for eleverne udviser ikke signifikante ændringer over de tre undersøgelsesrunder.

\section{Skoleforvaltningerne}

I 2015 arbejder kommunerne fortsat med inklusion - selv om de som gennemsnit har nået målet om en inklusionsprocent på 96. Kommunerne har under processen etableret målsætninger, der er udarbejdet strategier, og man er stadig i gang med at implementere. Der har været tale om en ganske krævende udviklingsproces, hvor inklusion er gået fra et overordnet ideal til gradvist at blive en del af praksis.

De kommuner, der har været tidligst i gang, har også iværksat forudgående kompetenceudviklingsprogrammer for medarbejderne, før inklusionen blev sat i gang rent organisatorisk. I de kommuner, der er gået i gang senere, er kompetenceudvikling og organisatoriske ændringer nærmest gået hånd i hånd. Der er ingen kommuner, der ikke har søgt at give personalet et kompetenceløft, og der har været afsat betydelige økonomiske ressourcer hertil. Der er også uddannet en lang række vejledere, som skal støtte lærere og pædagoger.

Det gælder for alle 12 kommuner, at man har ladet ressourcer følge med over i den almene undervisning. Nogle steder har man ligefrem relativt set - i forhold til de øvrige budgetter i kommunen - tilført ressourcer til inklusionsprocessen. Når man ser over de tre runder, hvor der er indsamlet data i de tolv kommuner, er der kun tale om marginale ændringer i kommunernes budgetter udregnet pr. elev, og ser man på regnskabstallene, er der sket en stigning i udgifterne til folkeskolen på 1,4 pct. pr. elev fra 2012 til 2014 i faste priser, men med betydelig variation de enkelte kommuner imellem. Der er ingen entydig sammenhæng med inklusionsprocenten.

I ti ud af de tolv kommuner er der etableret økonomiske incitamenter for inklusion, og der er hen over undersøgelsesperioden også gennemført en decentralisering af ansvaret for brugen af skolernes ressourcer, således at det i 2015 i alle kommuner er skolele- 
dernes ansvar at udmønte midler til supplerende undervisning og anden faglig støtte, inklusionsfremmende initiativer og specialundervisning.

Den mekanisme, hvormed man lader ressourcerne følge med over i almenundervisningen, er imidlertid ofte uigennemskuelig for personalet på den enkelte skole, især når der samtidig har været tale om generelle besparelser.

Der er fra 2013 til 2015 sket en reduktion i antallet af specialklasser fra 282 til 195 og en reduktion i antallet af specialskoler fra 19 til 15. Hvis man ser på elevtallet, er der i perioden sket en reduktion på 17,6 pct. i specialklasser og 15,4 pct. i specialskoler. Dette skal ses på baggrund af, at der i de 12 kommuner har været et generelt fald i elevtallet på 0,27 pct. fra 2013 til 2015.

Alt i alt gælder for skoleforvaltningerne, at alle tolv kommuner har taget inklusionsopgaven op, og at man på forskellig måde har ydet en væsentlig indsats for at skabe fællesskab om og ejerskab til inklusion fra forvaltningsniveau. Der er iværksat processer for at få skoleledere, skolebestyrelser, lærere og forældre med. Man har afholdt informationsmøder for alle forældre, og man har søgt en mere aktiv profilering af kommunens inklusionsstrategier i skriftlige materialer og på hjemmesider. Op gennem 2014 har der dog været en væsentlig "konkurrence" fra arbejdet med at implementere skolereformen, så inklusion står ikke længere som den mest centrale dagsorden.

\section{PPR}

PPR har spillet en væsentlig rolle i inklusionsbestræbelserne, og man har mange steder erkendt, at der er et klart behov for anderledes kompetencer i bemandingen end de traditionelt psykologiske. PPR har generelt også gennemgået en stor udvikling. Fra 2013 til 2015 er der endvidere en klar tendens til, at kommunerne arbejder på at udbygge det tværfaglige samarbejde på tværs af forvaltninger med henblik på at kunne støtte en tidlig indsats.

Visitationsprocesserne har fået mindre betydning ved overgangen til, at skolerne i høj grad selv skal finansiere specialtilbud. I 2015 er det et fælles træk for flere af PPRenhederne, at de arbejder på at etablere en hel fast struktur for, hvornår en elev bør indstilles til visitation. Dette sker for at sikre, at der arbejdes tilstrækkeligt med eleven i almenmiljøet.

I 2013 gjaldt, at PPR's placering som en central eller decentral enhed tæt på praksis rummede både fordele og ulemper. I 2015 er der i alle tilfælde sket en decentralisering enten til skoler eller til distrikter. Hvor sidstnævnte er sket, er også socialrådgivere og andet personale med støttefunktioner blevet flyttet ud. 


\section{Skoleledelserne}

Skolelederne har for hele perioden givet udtryk for en høj grad af opbakning til inklusionsmålsætningen, og der er især i 2012 og 2013 iværksat en række aktiviteter for at fremme opbakningen hos det pædagogiske personale, herunder først og fremmest kompetenceudvikling af lærere og pædagoger. Lederne har dog i hele perioden givet udtryk for, at der er lav opbakning til inklusion blandt skolernes personale. Lederne vurderer endvidere, at lærerne stort set ikke har incitamenter til at være inkluderende.

Skolelederne på langt de fleste skoler tilkendegiver, at en række ressourcer til inklusion er tilgængelige bl.a. muligheden for rådgivning fra PPR, samarbejde med skolens specialcenter/ressourcecenter samt bistand fra AKT-vejlederen på skolen. Tilgængeligheden af nogle af disse ressourcer, fx inklusionsvejleder på skolen, er steget fra 2013 til 2014. I 2015 er andelen af skoleledere, der tilkendegiver, at en række ressourcer til inklusion er tilgængelige, faldet markant. Skolelederne mener dog over hele perioden, at samarbejdet med PPR fungerer godt.

Skolelederne vurderer, at der er en vis opbakning til øget inklusion blandt forældre til børn med særlige behov, mens opbakningen er lavere hos forældre til elever uden særlige behov.

\section{Lærerne}

For lærernes vedkommende er resultaterne som allerede nævnt mindre positive. Det er under en femtedel af lærerne, som i perioden har været meget enige eller enige i opbakningen til inklusion. Det er i både 2013 og 2014 kun ca. en tredjedel af lærerne, der svarer, at de i meget høj grad, i høj grad eller i nogen grad er blevet tilbudt kompetenceudvikling i inklusion, hvad der står i stor kontrast til skolechefernes og skoleledernes udsagn. For 2015 gælder, at lærerne giver udtryk for, at der et sket fald i omfanget af kompetenceudvikling siden første runde.

Over halvdelen af lærerne syntes i hele perioden ikke at have tilstrækkelig faglig ballast til at håndtere udfordringer forbundet med inklusion. Med hensyn til tilgængeligheden af ressourcer i form af inklusionsvejleder, AKT-vejleder, medarbejdere fra skolernes ressourcecenter, rådgivning fra specialskoler, fra PPR eller videnscentre svarer lærerne generelt mere negativt i 2015.

Det er på mange måder bemærkelsesværdigt, at der er så stor forskel på skoleledernes og lærernes svar vedrørende opbakning til inklusion, kompetenceudvikling og adgang til ressourcer. For at belyse dette er der i tredje undersøgelsesrunde stillet supplerende spørgsmål til skolechefer og PPR-ledere. Disse har vist, at der i høj grad har 
været tale om top-down-beslutninger, at kompetenceudvikling ikke helt har gået på de aspekter, som lærerne føler behov for i det daglige arbejde, og at relationerne mellem vejledere og lærere ikke altid er uproblematiske. De frustrationer, som lærere føler, vurderes også at have sammenhæng med lockout og implementering af skolereformen.

\section{Eleverne og deres forældre}

Godt halvdelen af skolerne har afholdt en række aktiviteter og igangsat tiltag rettet mod fastholdelse af elevernes trivsel. Skolebestyrelsesformændene bakker op om den måde, som skolerne arbejder med elevernes trivsel på.

Data om elevernes trivsel viser, at forældrenes og elevernes svar på trivselsspørgsmålene i høj grad ligner hinanden. Helt generelt og ud fra elevernes egne vurderinger trives eleverne i 2 . klasse godt i skolen og eleverne i 8 . klasse trives endnu bedre. Der er ikke større forskydninger i trivselsmålene over de tre runder.

\section{Supplerende undervisning og anden faglig støtte}

Det er i gennemsnit 5,4 pct. af skolernes elever, som modtager supplerende undervisning og anden faglig støtte i skoleåret 2014/15, og der er ingen betydende forskydning over de tre runder, men en betydelig variation fra skole til skole. Hvis man går tilbage til 2011, den sidste opgørelse inden inklusionsloven, var det 6,6 pct. af alle skolers elever, der fik specialundervisning som supplement til den almene undervisning.

Skolelederne angiver, at der i gennemsnit er inkluderet 6,5 elever pr. skole pr. år over de tre runder, et relativt højt tal, når der ifølge de administrative oplysninger fra kommunerne faktisk er tale om, at 2,9 pct. er inkluderet, og 2,9 pct. ville svare til ca. 15 elever pr. skole i alt.

Hvad angår tilrettelæggelsen af den supplerende undervisning, viser besvarelserne fra skolelederne, at ca. en tredjedel af den supplerende undervisning hen over de tre runder er tilrettelagt således, at der er en ekstra lærer til stede i klassen. Herudover gives godt 10 pct. af den supplerende undervisning af lærerassistenter, og ca. en fjerdedel gives på skolens ressourcecenter.

\section{Faktorer af betydning for succesfuld inklusion}

På baggrund af de kvalitative og kvantitative data kan man fra de 12 kommuner uddrage en række overordnede faktorer af betydning for inklusion: 
- Tilstedeværelse af fælles værdigrundlag

- Kommunale strategier for arbejdet med inklusion

- Tilgængelighed til PPR's medarbejdere

- Opbakning fra forældrene til inklusionsmålsætningen

- Økonomiske incitamenter for inklusion

- Høj grad af kompetenceudvikling

- Tilgængelighed og anvendelse af vejledere

- Teamsamarbejdet som en ressource. 


\title{
Indledning
}

\author{
Af Niels Egelund
}

Undervisningsministeriet gennemførte i 2010 i samarbejde med KL og Finansministeriet en analyse af folkeskolens specialundervisning (Deloitte, 2010).

Undersøgelsen blev gennemført som en repræsentativ undersøgelse i 12 kommuner og kortlagde aktiviteter og ressourceforbrug. Den indeholdt endvidere en analysedel, der pegede på sammenhænge mellem kommunernes styring og organisering og andelen af elever, der inkluderedes i den almindelige undervisning.

På baggrund af undersøgelsen fremsatte en arbejdsgruppe med repræsentanter fra Finansministeriet, KL og Undervisningsministeriet en række anbefalinger, der kunne understøtte målsætningen om inklusion. En af de centrale anbefalinger var en ny afgrænsning af specialundervisningsbegrebet.

Som opfølgning på undersøgelsens anbefalinger blev det i kommuneaftalen for 2011 aftalt, at regeringen skulle gennemføre en lovændring, der klart afgrænsede specialundervisning, og at kommunerne skulle anvende inklusionsfremmende styringsmodeller, gøre PPR mere efterspørgselsstyret og arbejde strategisk med lærernes kompetenceudvikling for at opfylde målsætningen om inklusion.

\section{Lovændring om inklusion af elever i den almindelige undervisning}

Regeringen har i foråret 2012 med bred tilslutning i Folketinget gennemført en ændring af folkeskoleloven, der afgrænser specialundervisning til at være undervisning i specialskoler og specialklasser samt undervisning i den almindelige folkeskole, hvor eleven får støtte i mindst ni ugentlige timer. ${ }^{1}$

Lovændringen giver kommunerne mulighed for større fleksibilitet i forbindelse med at tilrettelægge en inkluderende undervisning.

\footnotetext{
${ }^{1}$ Jf. LOV nr. 379 af 28. april 2012 om ændring af lov om folkeskolen, lov om friskoler og private grundskoler m.v. og lov om folkehøjskoler, efterskoler, husholdningsskoler og håndarbejdsskoler (frie kostskoler). Inklusion af elever med særlige behov i den almindelige undervisning og tilpasning af klagereglerne til en mere inkluderende folkeskole m.v.
} 


\section{Aftale om kommunernes $\varnothing$ konomi for 2013}

Regeringen og KL har i Aftale om kommunernes økonomi for 2013 (ØA13) aftalt konkrete målsætninger for en succesfuld omstilling til inklusion. Målsætningerne omfatter andelen af elever, der inkluderes i den almindelige undervisning, det faglige niveau og elevernes trivsel.

Parterne vil i den forbindelse have fokus på kompetencer, inklusionsfremmende styringsmodeller og opbakning til inklusion.

Det fremgår af aftalen, at der skal ske en årlig afrapportering af status på omstillingen til øget inklusion, og omstillingen skal foreløbig følges over tre år. I den forbindelse gennemføres en tilbagevendende repræsentativ undersøgelse i 10-12 udvalgte kommuner. Data om supplerende undervisning skal indgå i undersøgelsen.

Forud for ØA13 har en tværministeriel arbejdsgruppe med repræsentanter fra Finansministeriet, KL og Ministeriet for Børn og Undervisning udarbejdet en rapport med oplæg til en dokumentationsmetode. Rapporten indeholder blandt andet bud på mulige målepunkter i forhold til en vellykket inklusionsindsats og en bruttoliste over mulige indikatorer.

Arbejdsgruppen kom på baggrund af en kortlægning af de eksisterende datakilder på inklusions- og specialundervisningsområdet, som indberettes af skolerne til Danmarks Statistik og UNI-C, med et forslag til en bruttoliste af data, som kan dokumentere omstillingen til øget inklusion i alle landets kommuner.

Arbejdsgruppen pegede dog på, at det ikke er muligt gennem udgiftsdata, elevdata eller data, som knytter sig til lærernes ressourceforbrug, fuldt ud at følge indholdsmæssigt op på den omstilling, som i øjeblikket finder sted i kommunerne. En opfølgning på inkluderende styringsmodeller, visitationsprocesser, organisering af PPR m.fl. må derfor tage udgangspunkt $\mathrm{i}$ andre kilder end de eksisterende datakilder.

Arbejdsgruppen foreslog, at der gennemførtes en årlig, supplerende, kvalitativ undersøgelse i 12 udvalgte kommuner, hvor der sås på kommunernes omstillingsproces i retning af øget inklusion. Undersøgelsen skulle følge udviklingen i repræsentativt udvalgte kommuner med henblik på at følge op på målepunkter, som ikke kunne belyses gennem statistiske og økonomiske data.

Der blev peget på følgende fokuspunkter:

- Styringsmodeller i kommunerne (økonomiske incitamenter til inklusion)

- Organisering af PPR

- Visitationsprocessen

- Kompetencer (kompetenceudvikling, brug af ressourcepersoner og PPR mv.) 
- Pædagogiske metoder til inklusion

- Opbakning til inklusion.

Arbejdsgruppen foreslog, at der efter tre år gennemførtes en undersøgelse med det formål at analysere sammenhængene mellem kommunernes indsatser og elevernes faglighed, trivsel og overgang til ungdomsuddannelserne med henblik på at kvalificere effekten af de inkluderende metoder.

Aftalen om dokumentation af kommunernes omstilling til øget inklusion i ØA13 bygger på arbejdsgruppens rapport.

\section{Opfølgning på aftalen om dokumentation af kommunernes omstil- ling}

Som opfølgning på ØA13 har Finansministeriet, KL og Ministeriet for Børn og Undervisning aftalt, at afrapporteringen på landsplan skal ske gennem den sædvanlige dataindsamling med udgangspunkt i fokuspunkterne fra arbejdsgruppens rapport. Afrapporteringen på landsplan vil blive gennemført af arbejdsgruppen på baggrund af data fra UNI-C og Danmarks Statistik.

Afrapportering vedrørende fokuspunkterne, herunder supplerende undervisning, skal ske ved den anbefalede tilbagevendende, repræsentative undersøgelse i 12 kommuner.

\section{Opgavens formål}

Opgaven med at gennemføre den tilbagevendende, repræsentative undersøgelse i 12 kommuner blev efter udbud givet til et konsortium bestående af Aarhus Universitet og SFI. Formålet med undersøgelsen er at belyse kommunernes omstillingsproces i lyset af de ændrede rammer for inklusionsindsatsen, herunder hvordan de udvalgte kommuner pædagogisk og styringsmæssigt har håndteret omstillingen til øget inklusion. Dermed er formålet at give et repræsentativt indtryk af, hvordan kommunerne arbejder med målsætningerne for en succesrig omstilling, og hvordan det går med fokuspunkterne. De årlige afrapporteringer skal indgå i den politiske opfølgning på omstillingen til øget inklusion som del af aftalen om kommunernes økonomi.

Den afsluttende analyse efter tredje dataindsamlingsrunde har til formål at sammenholde og analysere de forskellige kommuners inklusionsindsats i forhold til de målsætninger, som regeringen og KL har opstillet. Dermed er formålet med den afsluttende analyse at bidrage med viden om hvilke pædagogiske og styringsmæssige tilgange, som 
har den største effekt på fx læring og trivsel. Den afsluttende analyses resultater skal ses i lyset af effektiv anvendelse af ressourcer.

Undersøgelsen har skullet være i overensstemmelse med den forstålse af inklusion, som ligger til grund for regeringen og KL's aftale om øget inklusion i folkeskolen, fremsat i aftalen om kommunernes økonomi i 2013. Dette indebærer, at succesrig inklusion indbefatter, at færre elever henvises til specialskoler og specialklasser, at elevernes faglige niveau forbedres, og at elevernes trivsel fastholdes. Der henvises i øvrigt til forarbejderne til lov nr. 129 "Inklusion af elever med særlige behov i den almindelige undervisning og tilpasning af klagereglerne til en mere inkluderende folkeskole". 


\section{Metode}

\section{Indledning}

Dokumentationsprojektet består af tre tilbagevendende undersøgelser i 2013, 2014 og 2015. Alle tre undersøgelser indeholder kortlægninger af kommunernes omstillingsprocesser til øget inklusion samt en beskrivelse af udviklingen i de landsdækkende registerdata i de kommuner, der deltager i undersøgelsen. Undersøgelsen i 2015 indeholder endvidere en samlet, tværgående analyse af kommunernes indsatser i forhold til de i projektet opstillede mål og fokuspunkter.

Det samlede undersøgelseskompleks skulle dække et repræsentativt udsnit af eleverne i folkeskolen. Der er derfor foretaget et nøje udvalg af kommuner, og inden for disse er der inddraget alle skoler og udtaget elever og forældre fra skolernes 2. og 8 . klasser. Netop de to klassetrin er valgt, fordi en væsentlig del af inklusionen kunne antages at bestå i, dels at elever ikke længere blev visiteret til specialtilbud inden for de første skoleår, dels at elever inde i skoleforløbet blev hjemtaget.

Kortlægningen af det repræsentative udsnit af kommuner sker via kvalitative og kvantitative indsamlingsmetoder og beskriver følgende fokuspunkter:

- Inklusionsfremmende styringsmodeller

- Kompetencer

- Opbakning til inklusion

- Fastholdelse af elevernes trivsel

- Supplerende undervisning.

Følgende respondenter er udvalgt for at få en så bred dækning som muligt af de ovenstående fokuspunkter:

- Skolechefer

- PPR-ledere

- Skoleledere

- Skolebestyrelsesformænd

- Lærere

- Elever på 2. og 8. klassetrin

- Forældre til eleverne på 2. og 8. klassetrin. 
For skolechefer og PPR-leders vedkommende er der gennemført semistrukturerede kvalitative interview. For de øvrige respondenter er der anvendt særskilte spørgeskemaundersøgelser også betegnet som survey.

Der er desuden suppleret med dokumentanalyser af materialer indsamlet i kommunerne.

\section{Valget af kommuner}

Der er til brug for dokumentationsprojektet udvalgt 12 kommuner, der kan antages at have en repræsentation for de forskelle, der er mellem kommuner i hele landet. På denne baggrund kan det sandsynliggøres, at trends i disse kommuner er sigende for trends i alle kommuner i hele Danmark.

Der er valgt fire kommuner, som er bykommuner, og otte kommuner, der er landkommuner. De fire bykommuner er valgt blandt kommuner, der stort set kun har bymæssig bebyggelse. De otte landkommuner er valgt blandt kommuner med mindre byer og et stort opland. Det samlede udvalg har skullet dække Sjælland, Fyn og Jylland, og der er foretaget et valg, så der i 2013 var en ligelig fordeling af byer med "blåt" flertal og "rødt" flertal i kommunalbestyrelsen. Valget af kommuner har skullet rumme segregeringsprocenter både over og under, hvad man kunne forvente ud fra kommunernes socioøkonomiske baggrund, idet der dog er valgt nogle få kommuner med høj segregeringsgrad, uden at det påvirker repræsentativiteten væsentligt. Med hensyn til segregeringsprocenter gælder i øvrigt, at de syv største bykommuner i Danmark alle ligger under gennemsnittet. Segregeringsprocenter anvendt i forbindelse med valget af kommuner er taget fra KREVI (2011), Bilag 1.

Kommunerne i undersøgelsen er anonyme og betegnes med et bogstav. Hver enkelt kommune er dog blevet bekendt med, hvilket bogstav kommunen er tildelt. Anonymiseringen er sket, da der i forbindelse med inklusionsprocessen indgår en kompleks række af politiske, administrative, personalemæssige og pædagogiske overvejelser, ligesom processen kan være mere eller mindre velforberedt, og vi har ikke ønsket at sende oplysninger om navngivne kommuner ud i offentligheden. Formålet med undersøgelsen er at give et bredt billede af, hvad der foregår, samt at give kommunerne mulighed for at lære af hinanden.

\section{Undersøgelsesmetoder i 1. del af rapporten}

I undersøgelsen i kommunerne, der indgår i 1. del af rapporten, er der dels anvendt kvalitative metoder, dels kvantitative metoder. De kvalitative metoder er anvendt, hvor der 
ikke forud kunne defineres kategorier eller parametre, der gjorde en forlods operationalisering mulig. Som eksempel kan nævnes økonomiske incitamenter til inklusion, hvor stort set alle kommuner anvender forskellige metoder, der består af kombinationer af centrale og decentrale modeller, som først har kunnet afdækkes, efter at der er gennemført interview med skolechefer (eller forvaltningsmedarbejdere med denne funktion).

Efter at de kvalitative undersøgelser i alle 12 kommuner i foråret $2013 \mathrm{blev}$ gennemført, skete der en kvantificering på et antal parametre, der gjorde en sammenligning mellem kommunerne og inden for kommunerne over de tre år mulig. Der var en forventning om, at der løbende ville ske ændringer i kommunernes praksis over de tre år, og der blev derfor gennemført nye, kvalitative undersøgelser ved interview med skolechefer og PPR-ledere i 2014 og 2015. Fordelen ved de kvalitative metoders anvendelse i forbindelse med projektet var, at der har været en interaktion mellem interviewer og respondent, som har givet mulighed for uddybelse og begrundelse af svar, ligesom det har været muligt at afdække både manifeste og latente holdninger og motiver, der ikke kan undgå at være et led i såvel skoleforvaltningernes som PPR-enhedernes strategier og omlægninger af praksis.

Ved kvalitative interview er der blevet brugt en blanding af semistrukturerede og strukturerede metoder for at sikre, at der kunne ske en maksimalt sammenlignelig indsamling af oplysninger. De semistrukturerede metoder er blevet anvendt, hvor der forlods var en relativt beskeden viden om, hvordan kommuner eller skoler agerede, fx hvilke pædagogiske metoder eller former for kompetenceudvikling kommuner og skoler brugte til inklusion. De strukturerede metoder er anvendt, hvor der med stor sandsynlighed kunne forudsiges at være nogle ganske bestemte fremgangsmåder eller principper, fx hvilke ressourcer der var tilgængelige og kunne anvendes af lærerne i tilrettelæggelsen af inklusionsarbejdet. I forbindelse med brugen af kvalitative metoder blev der både nedskrevet noter i spørgeark og foretaget lydoptagelser, som kunne dokumentere data. Analysemetoden har fortrinsvis været en afsøgning af temaer, dvs. forhold, der går igen på tværs af kommuner eller skoler, og hvor det har kunnet lade sig gøre, er der som nævnt foretaget en kvantificering af oplysningerne fra de tematiske områder.

De kvantitative metoder blev anvendt, hvor der forlods har kunnet ske en sikker operationalisering af spørgsmål og emnekredse, og hvor der allerede forelå data i offentlige registre, fx UNI-C eller Danmarks Statistik, eller hvor kommuner og skoler kunne levere data, der allerede var kvantitative, $\mathrm{fx}$ antal af elever i forskellige foranstaltninger. Det skal i den forbindelse nævnes, at der er brugt kvantitative metoder overalt, hvor det overhovedet var muligt, herunder kvantificering af kvalitative data for at opnå det sikrest mulige sammenligningsgrundlag. 


\section{Undersøgelsesmetoder i 2. del af rapporten}

Formålet med surveydelen er at undersøge omstillingsprocessen til øget inklusion ud fra henholdsvis skolelederne, lærerne, bestyrelsesformændene, eleverne og forældrenes perspektiver. Der er defineret følgende fem fokuspunkter for arbejdet med øget inklusion i folkeskolen:

1. Inklusionsfremmende styringsmodeller

2. Kompetencer

3. Opbakning til inklusion

4. Fastholdelse af elevernes trivsel

5. Supplerende undervisning.

For hvert af de fem fokuspunkter anvendes resultaterne fra spørgeskemaundersøgelserne blandt skolelederne, lærerne og bestyrelsesformændene på skolerne i de 12 kommuner. Hvad angår det fjerde fokuspunkt - fastholde af elevernes trivsel - inddrages desuden både resultaterne fra (1) trivselsmålingen blandt eleverne i 2. og 8. klasse og (2) undersøgelsen af forældrenes opfattelse af deres børns trivsel i skolen.

Der foretages to typer af statistiske analyser for hvert fokuspunkt. For det første analyseres de relevante spørgeskemasvar over tid, idet besvarelserne fra tredje og sidste indsamlingsrunde i foråret 2015 sammenholdes med resultaterne fra første indsamlingsrunde gennemført på samme tidspunkt to år tidligere. Dette gøres med t-test, hvorved det kan belyses, om forskellene i respondenternes gennemsnit på de relevante spørgsmål mellem første og tredje runde er statistisk signifikante, dvs., om der er mindre end 5-10 pct. sandsynlighed for, at forskellene skyldes tilfældigheder. Ved at sammenholde disse resultater med resultaterne fra den tilsvarende analyse i sidste rapport fra marts 2014 giver analysen et indblik i udviklingstendenserne i omstillingsprocessen over de tre år. Resultaterne fra alle tre indsamlingsrunder er præsenteret i tabelmaterialet i Appendiks.

For det andet analyseres sammenhængen mellem spørgeskemasvarene inden for ovenstående fem fokuspunkter og de syv inklusionsindikatorer, som blev opstillet ved projektets begyndelse i 2013. Dette gøres ligeledes med t-test. De syv inklusionsindikatorer er:

1. Startår for inklusionsprocessen

2. Grad af fælles værdigrundlag på forvaltningsniveauet

3. Grad af kompetenceudvikling

4. Grad af økonomiske incitamenter 
5. Kvalitet af samarbejde mellem skoleforvaltning og PPR

6. Ændring i inklusionsprocenten fra 2010 til 2013

7. Kommunernes socioøkonomiske indeks.

Inklusionsindikatorerne bliver i første del af rapporten beskrevet i forhold til hver af de 12 kommuner, der indgår i undersøgelsen. Kommunernes socioøkonomiske indeks pr. marts 2015 fremgår af figur B3.5 i Bilag 3. Kommunernes inklusionsprocent pr. marts 2015 fremgår af tabel B.3.2 i Appendiks.

For begge typer af statistiske analyser er det værd at bemærke, at man som følge af det relativt lave antal besvarelser i hver gruppe finder relativt få statistisk signifikante resultater. Dette forhold er særligt udtalt for analyser vedrørende skolelederne $(n=83)$ og bestyrelsesformændene $(n=77)$, idet der - i forhold til lærerne $(n=686)$ - har væsentligt færre besvarelser for disse to respondentgrupper. Derfor er det vigtigt at være opmærksom på, at der med analyserne beskrives tendenser til forskelle snarere end egentlige statistisk sikre forskelle. I denne forbindelse bør det desuden understreges, at det ikke er muligt at drage kausale fortolkninger på baggrund af analyseresultaterne. Årsagen hertil er, at de fundne sammenhænge/tendenser kan skyldes faktorer, som der ikke er kontrolleret for.

En tredje type analyse, der indgår i rapportens anden del, er en rent deskriptiv analyse af udviklingen i sammenhængen mellem inklusionsmålsætningen og inklusionsindikatorerne over de tre år i de 12 kommuner. Da sammenhængen mellem inklusionsmålsætning og inklusionsindikatorer bygger på et gennemsnit af de 12 kommuner i hver runde, giver det ikke mening at lave en egentlig statistisk analyse. I stedet er der, i Appendiks 3.B, en grafisk gennemgang af udviklingen i sammenhængene over de tre runder.

Surveydelen bygger på spørgeskemabesvarelser fra skoleledere, skolebestyrelsesformænd og lærere i de 12 kommuner. Spørgeskemaerne er alle webbaserede med lukkede svarkategorier, således at sammenligninger mellem kommuner og inklusionsindikatorer er mulige. Spørgeskemaerne er bygget op omkring de fem fokuspunkter.

Spørgeskemaerne blev udsendt som en del af en toleddet procedure. I institutionsregisteret på Undervisningsministeriets hjemmeside er der registreret i alt 150 folkeskoler i de 12 kommuner i skoleåret 2014/15. Af disse er otte hovedskoler på samme adresse som en af skolens afdelinger og tælles derfor ikke som særskilte skoler. Først blev der sendt en mail til skolelederne på samtlige 142 folkeskoler, hvor de blev bedt om at oplyse mailadresserne på skolebestyrelsesformanden og alle de lærere, som underviste på 2. og 8. klassetrin. Seks skoleledere reagerede ikke på henvendelserne, og fire skoleledere ønskede ikke at deltage i undersøgelsen. Herefter blev det webbaserede spørgeskema udsendt til skolelederne og til de bestyrelsesformænd og lærere, der var oplyst mailadres- 
ser på. Fraregnes de mailadresser, der er oplyst forkert (fx pga. tastefejl eller fordi adressen er nedlagt), blev der udsendt spørgeskemaer til i alt 124 skoleledere, 120 bestyrelsesformænd og 1.886 lærere i 2. og 8. klasse. Efter tre elektroniske rykkere opnåedes besvarelser fra i alt 83 skoleledere, 77 bestyrelsesformænd og 686 lærere, hvilket resulterede i en svarprocent på 67 blandt skolelederne, 64 blandt bestyrelsesformændene og 36 blandt lærerne. Svarprocenten blandt lærerne skal dog anses som et minimum, da en række lærere må formodes egentlig ikke at høre til populationen, hvilket er tilfældet, hvis lærerne fx ikke længere underviser i 2. eller 8. klasse, eller hvis de er sygemeldte og derfor ikke har mulighed for at deltage. I forhold til forrige dataindsamlingsrunde er svarprocenten 18 procentpoint højere blandt skolelederne og et enkelt procentpoint højere for både bestyrelsesformændene og lærerne. Der er dog også et partielt frafald, da nogle respondenter kun har udfyldt skemaet delvist, hvorfor antallet af respondenter varierer på tværs af spørgsmålene. Antallet af besvarelser på de enkelte spørgsmål er noteret under tabellerne i Bilag 2.

Ud over, at der i de tre spørgeskemaundersøgelser til lærere, ledere og bestyrelsesformænd er spurgt om en vurdering af elevernes trivsel i 2. og 8. klasserne på skolerne i de 12 udvalgte kommuner, er der gennemført en særskilt trivselsmåling. Denne er gennemført ved hjælp af "Termometeret", som er et værktøj til måling af elevers trivsel, der er udviklet og drevet af Dansk Center for Undervisningsmiljø (DCUM). Målingen foretages ved, at eleverne besvarer et elektronisk spørgeskema. Spørgeskemaerne er målrettet eleverne i henholdsvis indskolingen, på mellemtrinnet og i udskolingen. Heri spørges der ind til forskellige aspekter ved elevernes trivsel, sundhed og de fysiske rammer på skolen. I praksis er dataindsamlingen gennemført ved en henvendelse pr. mail til de klasselærere i 2. og 8. klasserne, som skolelederne i de 12 kommuner havde givet kontaktoplysninger på. Klasselæreren eller en kollega i klassen (via en nøje vejledning) blev bedt om at foretage trivselsmålingen ved hjælp af DCUM's termometer.

Som et supplement til trivselsmålingen blandt eleverne er forældrene til eleverne i 2. og 8. klasse spurgt om, hvordan de opfatter deres børns trivsel i skolen. Parallelt til elevundersøgelsen blev dataindsamlingen gennemført ved, at klasselærerne - via den samme henvendelse pr. mail og via en nøje vejledning - blev bedt om at kontakte forældrene til eleverne i 2. og 8. klasse via skolens Forældreintra og herigennem videresende et link til spørgeskemaet til forældrene. Denne fremgangsmåde resulterede desværre i en meget lav svarprocent, idet blot 594, 201 og 276 forældre i henholdsvis 2013, 2014 og 2015 besvarede spørgeskemaet. I hvilket omfang dette skyldes, at klasselærerne ikke har gjort forældrene opmærksomme på undersøgelsen, eller at forældrene har valgt ikke at besvare spørgsmålene, vides ikke. 
Af hensyn til fortroligheden er alle analyseresultaterne opgjort som et samlet gennemsnit for de 12 kommuner.

Det er undersøgt, om der er systematiske forskelle mellem de skoler, hvorfra der er modtaget mindst én besvarelse i hver runde fra en respondentgruppe (skoleledere, skolebestyrelsesformænd, lærere og elever), og de skoler, hvorfra der ikke er modtaget én eneste besvarelse. Resultaterne af denne analyse af frafald blandt skolerne er gennemgået i Bilag 5 i Appendiks og tyder samlet set på, at skoler, der har en ressourcestærk elevpopulation er let underrepræsenterede. Det betyder, at rapportens resultater måske er mindre retvisende for skoler med mere ressourcestærke elever.

\section{Afdækning af forskelle mellem leder- og lærersvar}

I de to første undersøgelsesrunder var det markant, hvor stor en divergens der var mellem skolelederes og læreres svar i surveydelene. Der er i 2015 foretaget yderligere analyser af disse forskelle, hvor der er anvendt både kvantitative og kvalitative metoder.

I den kvantitative del er der anvendt data fra spørgeskemaundersøgelserne blandt skoleledere og lærere - i alt 106 skoleobservationer. I analysen indgik der besvarelser fra 37 skoler fra runde 1 (2012/2013), 28 skoler fra runde 2 (2013/2014) og 41 skoler fra runde $3(2014 / 2015)$. Disse data har en panelstruktur, hvilket vil sige, at der er et antal skoler, som optræder to eller tre gange i de tre runder. Samtidig er der et forholdsvis lille antal skoler, som optræder i alle undersøgelsens runder, og et endnu mindre antal, hvorfra der er besvarelser både fra skolelederen og mindst én lærer på de variable, som indgår i analysen. For at udnytte disse data optimalt givet den begrænsning, at antallet af skoler er meget lille, samt for at lette fortolkning af regressionskoefficienterne er der anvendt lineær regression med random effects estimation, hvorved der tages højde for, at der både er varians mellem skolerne og inden for skolerne over tid. Resultaterne fra regressionsanalysen præsenteres i tabel B3.1 i Appendiks.

I den kvalitative del er der i de semistrukturerede interview med skolechefer og PPR-ledere i 2015 tilføjet en række ekstra spørgsmål. Svarene er analyseret tematisk. 


\title{
Del 1. Data fra skolechefer, PPR-ledere og skoleforvaltninger
}

\author{
Af Camilla Brørup Dyssegaard og Niels Egelund
}

\section{Præsentation af resultater fra de 12 kommuner}

I det følgende startes der med at give nogle brede portrætter af kommunerne, der giver læserne mulighed for at få et overordnet billede af de processer, kommunerne har været igennem.

Der startes med nogle skematiske, kvantitative basisoplysninger om kommunernes størrelse og urbaniseringsgrad, antallet af folkeskoler, frie skoler, specialklasser og specialskoler, som de så ud i januar 2015. Det er muligt at få oplysninger dækkende 2013 og 2014 i de to tidligere rapporter. Størrelse defineres i tre kategorier af hensyn til anonymiteten. En lille kommune er på under 30.000 indbyggere, en mellemstor kommune er på mellem 30.000 og 70.000 indbyggere, og en stor kommune er på over 70.000 indbyggere.

Derpå følger andelen af elever i frie skoler i kommunen, igen gældende for januar 2015.

Videre følger nettodriftsudgifter pr. folkeskoleelev i 2012, 2013 og 2014 indhentet fra Danmarks Statistik. Der suppleres med en_angivelse af, hvor meget den faktiske udgift i 2008 afveg fra, hvad kommunens socialøkonomiske indeks tilsagde. Når året 2008 er valgt, er det, fordi det er det eneste år, hvor der findes en offentligt tilgængelig beregning. Det vurderes, at forskellen i faktisk og forventet udgift er en god indikator for en kommunes ressourcetildeling til skolen, idet den dog vil være en del påvirket af kommunens skolestruktur, om der fx er mange små skoler.

Det angives dernæst med udgangspunkt i KREVI (2011), hvad inklusionsprocenten var i skoleåret 2009/10, og hvor meget den ligger over eller under, hvad der skulle kunne forventes ud fra kommunens socialøkonomiske indeks i 2008, og dette efterfølges af en angivelse af inklusionsprocenten i marts 2013, marts 2014 og januar 2015. Tal fra 2013, 2014 og 2015 stammer fra det skema om administrative oplysninger, der er indgået som supplement til interviewene i kommunerne, og de kan sammenholdes med målsætningen om 96,0 pct. i 2015, der dog skal ses som et gennemsnit for Danmark som helhed. Tallene vil afvige lidt fra de tal, der oplyses i officielle statistikker, idet disse ikke tager 
højde for hvor mange af en kommunes elever, der går i frie skoler. Frie skoler giver specialundervisning, men har ikke specialklasser, ligesom frie skoler ikke må være specialskoler. Al segregeret specialundervisning i kommunerne foregår derfor i folkeskoler, og en høj andel af elever i frie skoler vil derfor sænke en kommunes officielle inklusionsprocent.

Endelig indgår kommunens socialøkonomiske indeks for 2015, der er taget fra www.noegletal.dk. Ved socialøkonomisk indeks forstås et nøgletal, som måler kommunens relative udgiftsbehov i forhold til andre kommuner på basis af en række socioøkonomiske kriterier, der indgår med forskellig vægt $\mathrm{i}$ beregningen. Det er kriterier som $\mathrm{fx}$ 'Antal 20-59-årige uden beskæftigelse' og 'Antal psykiatriske patienter'. Den præcise definition kan findes i Økonomi- og Indenrigsministeriets publikation 'Kommunal Udligning og Generelle Tilskud 2008', side 40. En værdi over 1 betyder, at kommunen har et relativt større udgiftsbehov i forhold til gennemsnittet af kommunerne, imens en værdi lavere end 1 betyder et relativt lavere udgiftsbehov i forhold til gennemsnittet.

Efter de skematiske, kvantitative basisoplysninger følger korte redegørelser for de processer, kommunen har været igennem. Formålet er at få dannet et billede, en kommunal forvaltning vil kunne identificere sig med. Først dækkes resultater fra interview med skolechef, dernæst fra interview med PPR-leder. Efter de brede kommuneportrætter følger resultaterne af en analyse af tematikker, der henholdsvis fremmer eller hæmmer inklusion. Herefter følger et afsnit, hvor henholdsvis skolechefers og PPR-lederes refleksioner over de store forskelle mellem skolelederes og læreres svar i de kvantitative dele af undersøgelsen. Endelig er der tabeller med angivelse af resultater vedrørende de kvantitative oplysninger fra skolechefer, PPR-ledere og kommunernes forvaltninger samt data fra Danmarks Statistik vedrørende nettodriftsudgifter pr. elev. 


\section{Kommuneportrætter}

\section{Kommune A}

\begin{tabular}{|l|l|}
\hline Kommunetype & Mindre bykommune \\
\hline Antal folkeskoler 2015 & 8 \\
\hline Antal frie skoler 2015 & 0 \\
\hline Andel elever i frie skoler 2015 & 5,0 pct. \\
\hline Antal specialklasser 2013-2015 & $20-21-22$ \\
\hline Antal specialskoler 2013-2015 & $2-2-2$ \\
\hline Nettodriftsudgifter pr. elev 2012-2014 & $69.332 \mathrm{kr} .-66.615 \mathrm{kr} .-68.646 \mathrm{kr}$. \\
\hline $\begin{array}{l}\text { Ændring nettodriftsudgifter 2012-2013 } \\
\text { Endring nettodriftsudgifter 2013-2014 } \\
\text { Ændring nettodriftsudgifter 2012-2014 }\end{array}$ & $-3,9$ pct. \\
\hline Socialøkonomisk indeks 2015 & $-1,0$ pct. \\
\hline $\begin{array}{l}\text { Udgift pr. elev i forhold til socialøkono- } \\
\text { misk indeks }\end{array}$ & 0,53 \\
\hline Inkluderet andel 2010 & -1.400 kr. \\
\hline Inkluderet andel 2013-2015 & 94,2 pct. \\
\hline
\end{tabular}

\section{Skoleforvaltning}

Kommunen vedtog i 2011 en overordnet definition af inklusion, som dækker hele 0-18årsområdet. Det er et politisk indsatsområde, som har ført til en ny skolepolitik med fire indsatsområder, hvor det ene er inklusion og fællesskab. Hermed forstås, at det at være en del af et fællesskab er en grundsten for læring, og man ønsker med en inkluderende tilgang at rumme alle kommunens børn i deres nærområde. Samtidig indgår som et yderligere element fokus på trivsel og undervisningsmiljø, hvor der sikres gode forhold for læring, afskaffelse af drilleri og mobning og sikring af elevernes medbestemmelse. Ud over den overordnede definition af inklusion har de enkelte skoler udarbejdet deres egne inklusionsstrategier. Der sættes mål for et år ad gangen, og målene evalueres af skoleleder, forvaltning og på politisk niveau, og der justeres på mål og indsatsområder fremadrettet i skolepolitikken.

Kommunen har fået støtte af ministeriets rådgivningsteam på både skole- og dagtilbudsområdet med hensyn til opstart af processen, opstilling af konkrete mål for arbejdet og etablering af kompetenceudviklingsforløb for 60 inklusionsagenter. Inklusionsagenterne betjener kommunens lokalområder. Erfaringerne viser dog, at det har været 
svært for inklusionsagenterne på skoleområdet at være vejledere for kolleger. Samtlige lærere og pædagoger i kommunen har deltaget i inklusionskurser.

Der er ikke arbejdet strikt på at tilpasse kapaciteten i kommunens specialtilbud, men byrådet besluttede fra starten, at man ville etablere en gruppeordning på hver af de otte folkeskoler med hver sin specialisering, og man prøver at hjemtage elever fra eksterne tilbud i disse ordninger i den udstrækning, det giver mening for børnene. Erfaringerne viser dog i 2015, at det er svært at opretholde bæredygtighed og tilstrækkelig pædagogisk faglighed i nogle af gruppeordningerne, da der er tale om relativt små enheder. Indsatser og ressourceforbrug til supplerende undervisning og anden faglig støtte til enkeltelever er decentraliseret til de enkelte skoler, der også bestemmer, hvorledes de vil anvende inklusionsfremmende initiativer. Skoler i de mest belastede områder får endvidere en ekstra basistildeling.

Kommunen har etableret et videnscenter, og det består af to klasselokaler på en skole, hvor også skolebibliotek og it-konsulent findes. I videnscenteret inddrages faglige fyrtårne omkring fx læsevejledning, så man ikke nødvendigvis behøver at sende lærerne på dyre eksterne kurser. Det er et mål, at der oprettes en digital vidensportal, som lærerne kan benytte.

Der har indtil videre ikke været en politisk diskussion af og beslutning om, hvorvidt kommunen skal indføre en økonomisk incitamentsstruktur i forhold til specialområdet og i arbejdet med inklusion. Der er flere forskellige politiske holdninger til dette, og der er ikke udarbejdet de nødvendige analyser i forhold til at kunne kvalificere beslutninger på dette område.

Med henblik på trivsel anvendes DCUM's termometer en gang om året, og fremover anvendes Undervisningsministeriets nye trivselsmålingsværktøj. I mange år har der været fokus på drengenes trivsel i folkeskolen, men i de seneste år har kommunen i højere grad fået øje på, at flere og flere piger er i mistrivsel og presser sig selv.

Forældre til inkluderede børn kan opdeles i to grupper: En, der vil have mere specialiserede indsatser, og en anden, der mener, at de faglige krav er for store. Der er få klager fra almenforældrene, hvorfor der opleves en generel tilfredshed.

Fra 1. januar 2015 er hele børne- og ungeområdet slået sammen. Hensigten er, at man skal "tænke anderledes". Kommunen er opdelt i seks skoledistrikter, og forvaltningen i kommunen har fået til opgave at udarbejde scenarier og forslag til, hvordan man fremadrettet kan ændre børne-, unge- og skolestrukturen. Kommunen skal som mange andre kommuner spare på driftsudgifterne i de kommende år, derfor er man interesseret $i$ at undersøge mulighederne for at spare på "mursten" frem for "varme hænder".

I forhold til inklusionsmålsætningen er man på rette vej, og kommunen forventer, at man vil ligge meget tæt på målsætningen om 96 \% ved udgangen af 2015. Det under- 
søges løbende, om der sker reduktioner i antallet af indstillinger til PPR, og om man kan se ændringer $\mathrm{i}$ antallet af indstillinger. Man erkender, at det tager tid at implementere ændrede forventninger til inklusion, og dette blev yderligere udfordret af, at der samtidig med, at inklusionsprocessen blev sat i gang i 2010, skulle spares 100 mio. kr. på hele det kommunale budget. Dette var i den grad med til at udfordre inklusionsforståelsen hos mange lærere. Den økonomiske situation er fortsat et problem i 2015, der er blandt andet nedlagt ca. 20 stillinger i 2015, hvilket har krævet ændringer i mange skolers fagfordelinger. Besparelsen skal være 4,4 pct., og den kan i værste fald accelerere i de kommende år op til 9 pct. af lønsummen. Årsagen er dels fald i elevtallet, dels generelle besparelser, og dette vil lægge arbejdet med inklusion under pres fremover.

\section{PPR}

Den 1. januar 2011 blev der foretaget en større organisationsændring i den kommunale forvaltning. PPR, der tidligere havde ligget i Børne- og Ungeafdelingen, der havde basis i det sociale regi, blev opdelt i to dele, hvoraf den ene del blev placeret i skoleforvaltningen. Det var en udfordring for personalet, da de havde været glad for deres tidligere organisering. Psykologerne havde indtil delingen arbejdet meget selvdefinerende, hvor de i skoleforvaltningen fik mere kontante retningslinjer for deres arbejde.

Den 1. januar 2014 indførtes en distriktsstruktur i PPR, hvor formålet var, at hver af kommunens skoler fik tilknyttet én bestemt psykolog, og tale-høre-pædagogerne skulle også indgå i distriktsstrukturen. PPR-medarbejderne skulle være til stede på skolerne og indgå i det daglige samarbejde omkring aktuelle udfordringer. Hensigten med distriktsstrukturen var, at PPR-medarbejderne skulle få kendskab til de lokale forhold og sammenhænge, således at de bedre kunne yde rådgivning og sparring tæt på de konkrete udfordringer. Endvidere skulle der være en løbende dialog mellem skoleleder, daginstitutionsleder og PPR- medarbejderen, således at der skabtes et fælles overblik over lokale behov og enighed om, hvordan opgaverne skulle prioriteres.

Fra 1. januar 2015 er hele 0-18-årsområdet lagt ind under én ledelse. Psykologerne oplever decentraliseringen som en stor udfordring, da de savner en fælles faglig base, hvor de kan få sparring fagligt og socialt. Denne udfordring forsøges imødekommet pr. 1. marts 2015 via et områdesamarbejde tre distrikter imellem, hvor psykologerne i de tre distrikter kan søge sparring med hinanden og aflaste hinanden ved et evt. særligt arbejdspres i ét distrikt. Der vil således blive to 'områdeteams'.

I november 2013 udsendte PPR en opgaveportefølje for PPR's arbejdsopgaver bl.a. inspireret af KL's pejlemærker for fremtidens PPR og et ønske om at komme den tidligere centralt organiserede venteliste til livs med målet om at blive inddraget tidligere og på et før-sagsniveau med et konsultativt fokus. I 2014 har PPR arbejdet med at implemente- 
re opgaveporteføljen, og ønsket fra PPR's side er, at skolerne fx tager afsæt i opgaveporteføljen omkring, hvad der skal ske, inden reelle indstillinger til PPR udarbejdes. Idéen med opgaveporteføljen er blandt andet, at PPR's ydelser skal blive mere efterspørgselsstyrede, men så langt er implementeringen ikke endnu. Der er stor forskel mellem skolerne på, hvor indgående et kendskab de synes at have til opgaveporteføljen og dermed muligheden for at inddrage PPR konsultativt fremfor via indstillinger, men den tættere sparring med skolelederne virker, og det opleves, at observationer bliver brugt mere. I daginstitutionerne er der stor begejstring for opgaveporteføljen, da de føler at have fået psykologerne meget tættere på.

Frem til 2014 var det den daglige koordinator af PPR og tale-høre-konsulenten, der sad som faste medlemmer af visitationsudvalget. Inden visitationen afholdtes et ledelsesmøde, hvor chef og souschef for skoleforvaltningen sammen med koordinatoren af PPR gik sagen igennem og blev afklaret på fx økonomidelen, således at koordinatoren af PPR var forberedt på visitationen. Fra 2014 er det er den daglige koordinator af PPR og chefkonsulenten på skoleområdet, der sidder som faste medlemmer af visitationsudvalget. Modtagende skole er altid med i visitationen.

I forhold til at få nedbragt antallet af indstillinger til visitationsudvalget er det PPR's opfattelse, at det bør diskuteres og vurderes, om der med fordel kan indføres incitamentsstyring. 


\section{Kommune B}

\begin{tabular}{|l|l|}
\hline Kommunetype & Mellemstor bykommune \\
\hline Antal folkeskoler 2015 & 12 \\
\hline Antal frie skoler 2015 & 3 \\
\hline Andel af elever i frie skoler 2015 & 12,1 pct. \\
\hline Antal specialklasser 2013-2015 & $12-6-5$ \\
\hline Antal specialskoler 2013-2015 & $2-2-2$ \\
\hline Nettodriftsudgifter pr. elev 2012-2014 & $68.799 \mathrm{kr} .-67.123 \mathrm{kr} .-70.671 \mathrm{kr}$. \\
\hline Ændring nettodriftsudgifter 2012-2013 & $-2,4$ pct. \\
Ændring nettodriftsudgifter 2013-2014 & 5,3 pct. \\
Ændring nettodriftsudgifter 2012-2014 & 2,7 pct. \\
\hline Socialøkonomisk indeks 2015 & 0,66 \\
\hline Udgift pr. elev i forhold til socialøkono- & 3.500 kr. \\
misk indeks & \\
\hline Inkluderet andel 2010 & 96,1 pct. \\
\hline Inkluderet andel 2013-2015 & 97,0 pct. - 97,4 pct. - 98,0 pct. \\
\hline
\end{tabular}

\section{Skoleforvaltning}

Det første initiativ til at starte en inklusionsproces skete i januar 2010, hvor kommunalbestyrelsen blev orienteret om et tværgående 4-årigt inklusionsprojekt, som senere blev vedtaget i 2011 med strategien "den gode inklusion". Hovedopgaven har været at sørge for, at alle børn har det godt og kan udvikle sig i de sociale og faglige relationer, de indgår $i$, og at de kan udvikle sunde relationer.

Hvad angår organisering, fik skolechefen i 2011 ansvaret for alle børn og unge op til 18 år, uanset hvor de var placeret (herunder døgnanbragte børn). Der blev skabt nye grundvilkår for økonomien uden kassetænkning mellem det specialiserede og det almene område. Dernæst blev der taget fat i ledelsen, så der opstod en inklusionsforståelse. Der blev over en 4-årig periode afsat et beløb svarende til 2,2 pct. af et enkelt års samlede skolebudget, og disse midler blev primært anvendt til kompetenceudvikling.

Der blev etableret en række specifikke indsatsområder: Incitamentsstruktur, kompetenceudvikling, intern organisering, specialtilbud som kompetencecentre, og der er ambitiøse mål om at etablere et familiehus opbygget som centralt rådgivningscenter, et fælles sagssystem med en kontaktperson og et digitalt system for elev- og handleplaner.

Der er sket en tilpasning af kommunens specialtilbud, specialklasser er kørt videre som gruppeordninger, det er lykkedes at reducere antallet af elever på en specialskole 
for ADHD-børn betydeligt, og størstedelen af eleverne med læsevanskeligheder undervises nu i almenklasser.

En inklusionsvejlederuddannelse blev etableret, da man vurderede, at de specialpædagogiske kompetencer efterhånden fuldstændig var forsvundet på de enkelte skoler. Inklusionsvejlederens primære rolle er at se på skolens organisering og tilrettelæggelse af supplerende undervisning og specialundervisning. Endvidere er de ansvarlige for at danne netværk på tværs af skolerne, dvs. at etablere gensidig erfaringsudveksling, således at et fælles vidensformidlingsforum er tilgængeligt, og fælles indsatsområder kan etableres. Der er opbygget ressourceteams på skolerne, hvor klasser eller lærere kan få vejledning omkring overordnede problematikker eller om et enkelt barn af en inklusionsvejleder eller en AKT-vejleder. Der er generelt skabt et kompetenceudviklingssystem og afsat ressourcer til, at medarbejdere med særlige kompetencer kan understøtte og give sparring i praksisfeltet. Det sker bl.a. gennem observation af en anden lærers undervisning og efterfølgende refleksion over den sammen med kollegaen.

Der har været et stærkt fokus på at flytte indsatsen fra specialtilbud til almentilbud. Hvis elever ønskes henvist til specialforanstaltninger, ser man først på, om og hvad almenskolen har gjort, og det gør, at skolerne ofte genovervejer egne muligheder. Alle lærere i kommunens specialtilbud er nu også ansat på almenskoler som en fleksibel ressource. Specialtilbuddene er også blevet pålagt, at eleverne skal gennemføre de nationale test, og det har i mange tilfælde flyttet fokus fra socialpædagogik over på faglig progression. Kommunens specialklasser har nu elever, der tidligere var blevet sendt på eksterne specialskoler. Der er i 2015 ved at blive etableret et familiehus, hvor de tungeste børnesager samles.

Alle ressourcer fra inkluderede elever følger med over i almenundervisningen, og der er desuden tilført et overgangsbeløb, og de mest inklusionsunderstøttende aktiviteter synes at være vejlednings- og støttesystemet til almenundervisningen kombineret med den økonomiske incitamentsmodel. Ansvaret for, at eleverne får den støtte, de har behov for, ligger hos skolelederne.

I forhold til forældrene til de inkluderede elever har der ikke været nogen klager, hvorfor det opleves, at de er godt tilfredse. Der har dog været en del klager fra forældre til elever uden særlige behov, og skolechefen betegner disse som meget modbydelige sager.

Med hensyn til supplerende undervisning og anden faglig støtte har skolerne et stort frirum til at udmønte ressourcer, men generelt tænkes meget i understøttende undervisning, og kommunen har dermed allerede taget hul på skolereformen. Når det gælder inklusionsindsatser, ligger anvendelsen helt op til skolelederne. Skolerne tildeles ressourcer ud fra elevtal, og derefter må skolen agere, som den finder bedst. 
Det erkendes i 2015, at de første fire år i høj grad har været brugt til ændring af organisering, og at man nu skal til at have fokus på praksisændringer, der understøttes af specialuddannede medarbejdere.

\section{PPR}

Hvad angår PPR, har det fra kommunens side siden 2011 været ønsket, at der var mere rådgivning, og at PPR dermed kom tættere på skolerne og daginstitutionerne. Der har været to lederskift inden for en treårig periode, og den seneste leder er tiltrådt i 2014. Der er sket en omstrukturering i psykologgruppen, hvor der arbejdes på at bevæge sig fra en mere traditionel tilgang til psykologarbejdet til en mere konsultativ. En væsentlig del af denne omstrukturering er at nedtone de enkelte faglige områder og sikre et tidligt tværfagligt sagsforløb.

En udfordring i forhold til omstillingsprocessen har været at få nedbrudt de "faglige siloer", som kunne karakteriseres som havende én faglighed med én faglig leder, hvor tendensen kunne være, at de lukkede sig om sig selv. Idéen med det tværfaglige sagsforløb er, at der ikke kun fokuseres på et enkelt område, men ses på den samlede kontekst, barnet indgår i, og på baggrund af dette samarbejde udarbejdes en plan for indsatsen. Der er på skolerne skabt et tæt samarbejde med ressourceteamene, som består af blandt andet AKT-lærere og inklusionsvejledere og psykologer, som opleves som værende meget værdifuldt. PPR og familieafdelingen er slået sammen og ligger nu under skoleafdelingen, hvad der har styrket fokus på det konsultative og tværfaglige arbejde.

Kommunen har igangsat et projekt omhandlende tidlig indsats og forebyggelse. Målet for projektet er, at børn skal have mulighed for at udvikle sig fagligt og socialt $\mathrm{i}$ deres lokale tilbud fremfor at blive udskilt til specialområdet. Der er tre områder, der er centrale i pilotprojektet: 1) kvalificering af en bekymring, 2) tidligt tværfagligt, koordineret sagsforløb, tidlig indsats og opfølgning og 3) ensartet inklusionspraksis.

I forhold til at kvalificere en bekymring er der arbejdet på, at der skal ske en metodisk afdækning af bekymringen, relevante ressourcepersoner inddrages, og der skal udarbejdes konkrete hjælpeværktøjer. I udviklingen af det tværfaglige sagsforløb skal der etableres en model for blandt andet, hvem der skal være tovholder, udvikles et indsatskatalog med fokus på tidlig indsats, systematik og evidens og udarbejdes hjælpeværktøjer.

Der er endvidere etableret en ny visitationsproces. Ansvaret for denne er fjernet fra den enkelte psykolog og har nu mere karakter af tværfaglige visitationer, hvor både sagsbehandlere og psykologer samarbejder. I 2015 er der fra PPR's side en oplevelse af, at skolerne har forstået deres ansvar, og det fremgår tydeligt, at der har været arbejdet 
omkring barnet inden en indstilling. De tilfælde, hvor PPR går direkte ind, er ved de virkeligt "tunge" sager.

I forhold til det kommende år er der en forhåbning om, at der vil blive givet flere ressourcer til at få styr på både inklusion og skolereform og eventuelle andre nye strategier.

\section{Kommune C}

\begin{tabular}{|l|l|}
\hline Kommunetype & Mellemstor bykommune \\
\hline Antal folkeskoler 2015 & 4 \\
\hline Antal frie skoler 2015 & 1 \\
\hline Andel elever i frie skoler 2015 & 7,8 pct. \\
\hline Antal specialklasser 2013-15 & $30-30-28$ \\
\hline Antal specialskoler 2013-15 & $1-1-0$ \\
\hline Nettodriftsudgifter pr. elev 2012-2014 & 85.573 kr.- 84.997 kr. $-87.887 \mathrm{kr}$. \\
\hline Ændring nettodriftsudgifter 2012-2013 & $-0,7$ pct. \\
Ændring nettodriftsudgifter 2013-2014 & 3,4 pct. \\
Ændring nettodriftsudgifter 2012-2014 & 2,7 pct. \\
\hline Socialøkonomisk indeks 2015 & 1,62 \\
\hline Udgift pr. elev i forhold til socialøkono- \\
misk indeks & 7.000 kr. \\
\hline Inkluderet andel 2010 & 89,7 pct. \\
\hline Inkluderet andel 2013-2015 & 91,4 pct. - 92,3 pct. - 92,5 pct. \\
\hline
\end{tabular}

\section{Skoleforvaltning}

I 2011 blev der vedtaget en overordnet definition af inklusion, der dækker hele 0-18årsområdet. Forud for dette havde der været en længere politisk diskussion både i børneudvalget, siden hen i økonomiudvalget og til sidst i kommunalbestyrelsen. Definitionen er, at børn og unge skal opleve, at de fællesskaber, de er en del af, er trygge og inkluderende.

Det er et krav fra kommunen, at alle dagtilbud, skoler, SFO'er og idræts-, kulturog fritidstilbud/klubber formulerer egne principper og mål for inklusion, der skal evalueres. Samtlige pædagogiske tilbud i kommunen har et forum, hvor det planlægges og drøftes, hvordan et inkluderende miljø i den enkelte enhed skabes og indrettes.

I efteråret 2013 er der indgået et samarbejde med Undervisningsministeriet, hvor der er udarbejdet en inklusionsstrategi med inklusionsvejledere, faglig vejledning og brug af PPR. Derefter følger, at man skal ud på skolerne og institutionerne, og der er sat måltal på. Der er sket en afvejning mellem gruppeordninger og fuld inklusion. Gruppen 
af medarbejdere, der arbejder med implementeringen, er blevet udvidet, og ud over inklusionsvejledere medvirker konfliktmæglere og SSP.

Der blev i 2011 sat det mål, at andelen af specialiserede tilbud skulle nedsættes med 5 pct. årligt over en treårig periode, og at de ressourcer, der blev frigivet herved, skulle overføres til skolernes normalundervisning. Ud over dette har man dog ikke fra politisk hold ønsket at sætte nøjagtige tal på, hvor man skulle ligge i forhold til økonomiaftalen.

Kommunen har helt bevidst ikke ønsket at etablere kontante økonomiske incitamenter til inklusion for de enkelte skoler i form af en pris pr. ekskluderet elev. Borgmesteren har udtalt, at skoleledere ikke skal sidde og passe på store pengekasser, men skal være pædagogiske ledere. Ressourcetildelingen til de enkelte skoler er elevtalsstyret. En ny skolechef, der er tiltrådt i slutningen af 2014, er i starten af 2015 af den opfattelse, at der må arbejdes for tydeligere målsætninger for inkludering og med en model for økonomiske incitamenter for inklusion, ligesom de flerfaglige enheder tæt på skolen skal opleves som frugtbare.

Man har følt i forvaltningen, at det største problem i implementeringen har været, at der ikke er samlet opbakning blandt lærerne. Der er dermed et væsentligt gab mellem det strategiske mål og lærernes overtagelse af målet. Ressourcerne mangler umiddelbart ikke, og i 40 pct. af tiden kan der være to lærere på hver klasse.

I forhold til forældre til inkluderede elever opleves der til tider lidt modstand, men det varierer også afhængigt af, hvor man er i byen. Forældrene til elever uden særlige behov opleves som tilfredse. Kommunen har også vægtet at holde informationsaften for forældre med inklusionskonsulenten.

Der er blevet arbejdet med kapaciteten i kommunens specialskole, som i 2014 er blevet opdelt i to enheder, en, som fortsat fungerer som specialskole, men er lagt ind som en afdeling på en almindelig folkeskole, og en, som varetager ad hoc-opgaver på skolerne, herunder "pusterum". Hvad specialklasser angår, er der en budgetramme; visitationsprocessen afføder en del klager fra forældre, når indsatsen besluttes givet i almenklasser. Det er alt i alt lykkedes at bringe eksklusionen ned, selv om man godt en gang imellem kan fundere over, hvad kvaliteten er på det individuelle plan i det inkluderende miljø.

Man sikrer, at ressourcerne følger med de inkluderede elever ved at ændre på skolernes ressourcefordeling, således at de inkluderede elever får 12 timer ekstra om ugen. Det er skolelederne, der omfordeler, og forældrene er glade for denne ordning.

Ressourcer til supplerende undervisning og anden faglig støtte fordeles af skolelederne alt efter, hvad der er mest hensigtsmæssigt over for en given elev. Vedrørende 
inklusionsindsatser tilstræbes også fleksibilitet, men der er en overordnet retningslinje om, at indskolingen skal tilgodeses særligt for at få en god skolestart.

\section{PPR}

Kommunen har en leder af PPR, som er kommunalt uddannet med en ekstra uddannelse i økonomisk ledelse. Lederen har erfaringer fra en administrativ stilling i kommunen, og disse erfaringer har sammen med en analyse af kommunens behov medført, at ansættelsesprofilen for personalet er ændret. Der er ansat konsulenter med didaktiske kompetencer, og der arbejdes netværksorienteret med inklusionsvejledere og AKT(adfærd, kontakt og trivsel)-konsulenter og andre medarbejdere med kompetencer i konflikthåndtering ude på skolerne. Derved er der skabt et slagkraftigt korps omkring opgavevaretagelsen, og det har været en stor gevinst, at der nu er bredspektrede typer af løsningsforslag på de enkelte skoler.

Kommunen har været udfordret af, at børne- og ungdomspsykiatriske afdelinger kommer med konkrete anbefalinger i forhold til de elever, der er blevet udredt, fx et lille, struktureret og overskueligt miljø. Der har været afholdt møder mellem de involverede parter, og der er fundet en konstruktiv løsning.

PPR har været aktiv i forbindelse med organisationsudvikling i kommunen, hvor de har deltaget i dannelsen af kompetencecentre, hvor der arbejdes med noget, kommunen kalder første led og andet led, hvor første led er det, der sker ude i periferien, hvor børnene har deres hverdag - her skal størsteparten af sagerne løses og PPR's indsatser primært lægges. Er sagen særligt udfordrende, kan den rejses overfor andet led, som er foranstaltningsområdet, hvis der kræves foranstaltninger efter serviceloven.

Visitationen foregår i et udvalg, hvor lederen af PPR, souschefen, psykologen tilknyttet specialtilbuddene, sekretæren og skolelederne sidder. Sager om visitation og revisitation drøftes på halvårlig basis, og det afvejes, om man er enige i psykologernes eller tale-høre-lærernes indstillinger. Der foretages en afvejning i forhold til tilbudsviften af specialtilbud og de alternative og inkluderende muligheder, der kan sættes op, idet den til rådighed stående økonomi også indgår i betragtningerne. Der er møde i visitationsudvalget en gang om måneden, hvor den løbende trafik og drift tages op.

I 2013 blev støttepædagogerne organisatorisk lagt ind under PPR. Siden har deres arbejdsopgaver ændret fokus fra at støtte barnet til direkte at støtte pædagoger og lærere omkring barnet. Alle støttepædagoger har været på et aktionslæringskursus. Det arbejde, de udfører nu, er, hvad de kalder organisatorisk læring, hvor de faktisk underviser pædagoger eller lærere i selv at kunne støtte barnet. Placeringen af støttepædagogerne i PPR har gjort, at de kan bruges mere strategisk, hvor de tidligere var støtte på ét enkelt 
barn i seks måneder. Det har også øget muligheden for tværfagligt samarbejde og har været en styrkelse af tidlige indsatser, som er noget, kommunen satser på.

PPR arbejder i 2015 mere konsultativt. Det er PPR-lederens oplevelse, at PPR er blevet mindre forbundet med "fjern og fix"-etiketten og arbejder mere i almenmiljøet. Det opleves endvidere, at den konsultative tilgang med supervision er med til at gøre lærerne i stand til at løse opgaven.

Kommunen føler sig udfordret i forhold til at nå 96 pct.-målsætningen i 2015. Kommunen har rigtig mange segregerede børn. Kommunen tiltrækker endvidere forældre med børn med særlige behov. Det er ikke planen at lukke specialtilbud, da dette ikke vurderes som en god løsning. Kommunen arbejder med at udvikle en plan for at nedbringe antallet af segregerede børn, men mener, at det kræver en længere proces.

I forhold til forventninger til det kommende år håbes der på, at antallet af inkluderede elever vil stige. I 2015-2016 skal 2-3 specialklasser lukkes, og besparelsen opnået herved skal føres tilbage til at styrke almenområdet. Det er endvidere forventningen, at de ca. 65 elever, der går i et tilbud uden for kommunen, vil være uændret.

\section{Kommune D}

\begin{tabular}{|l|l|}
\hline Kommunetype & Mellemstor landkommune \\
\hline Antal folkeskoler 2015 & 12 \\
\hline Antal frie skoler 2015 & 4 \\
\hline Andel af elever i frie skoler 2015 & 7,8 pct. \\
\hline Antal specialklasser 2013-2015 & $27-27-11$ \\
\hline Antal specialskoler 2013-2015 & $0-0-0$ \\
\hline Nettodriftsudgifter pr. elev 2012-2014 & $67.252 \mathrm{kr} .-66.673 \mathrm{kr} .-71.601 \mathrm{kr}$. \\
\hline $\begin{array}{l}\text { Endring nettodriftsudgifter 2012-2013 } \\
\text { Ændring nettodriftsudgifter 2013-2014 }\end{array}$ & $-0,9$ pct. \\
Ændring nettodriftsudgifter 2012-2014 & 7,4 pct. \\
\hline Socialøkonomisk indeks 2015 & 0,5 pct. \\
\hline $\begin{array}{l}\text { Udgift pr. elev i forhold til socialøkono- } \\
\text { misk indeks }\end{array}$ & 300 kr. \\
\hline Inkluderet andel 2010 & 92,5 pct. \\
\hline Inkluderet andel 2013-2015 & 93,2 pct. - 94,1 pct. - 95,2 pct. \\
\hline
\end{tabular}

\section{Skoleforvaltningen}

Kommunen reviderede i 2010 "Den Sammenhængende Børnepolitik" med en beskrivelse af, hvilke forventninger der er til kvaliteten i arbejdet inden for Børne- og Familieforvaltningens område. Kommunen har i sin skolepolitik defineret inklusion som deltagelse i læringsfællesskabet, således at eleven er sammen med og aktivt deltager i samme un- 
dervisning og fællesskab som sine klassekammerater med den hensigt, at eleven opnår optimalt udbytte af og får et positivt selvbillede på baggrund af deltagelse i læringsfællesskabet.

Udviklingen af en inkluderende skole bygger videre på tidligere initiativer. Man fik i 2006 i forbindelse med kommunesammenlægningen midler til at styrke dagtilbuddene i to treårige udviklingsprojekter, der havde både et medarbejder- og et ledelsesperspektiv. Fra 2008 var der fokus på elevfravær, som udgjorde et stort problem. Fra og med budget 2010 blev der sat ekstra midler af til inklusion og støtte til familier. Fra 2015 er satsningen, at man vil undlade at bruge begrebet inklusion. Nu drejer der sig om at sikre alle "læring og trivsel".

Kommunen har ikke selv nogen specialskoler, men anvender specialklasser i og uden for kommunen. Der har været konstateret en "stærekasseeffekt", hvor der hele tiden fyldes op, og det er særligt elever med AKT-vanskeligheder, som ekskluderes. Der er sat fokus på sammen med familierådgivningen og AKT-vejlederne at prøve at reducere antallet af elever, der henvises til specialklasser, hvilket tydeligvis er lykkedes med reduktion af antallet af specialklasser til følge. Faldet i antallet af henviste elever hænger først og fremmest sammen med, at der henvises færre, ikke at man hjemtager allerede segregerede elever. Lærerne har følt sig magtesløse over for disse elever, og man gør nu meget for at kvalificere lærerne med fokus på teamsamarbejde. Målet er som udgangspunkt, at mindst 94 pct. af eleverne fremover skal kunne undervises i distriktsskolen, men man er i 2015 bekymrede for, at man vil være 1,5 procentpoint fra at nå målet.

I 2011 satte kommunen fokus på udvikling af teamsamarbejde både for lærere og pædagoger. I denne forbindelse er der uddannet teamfacilitatorer til de enkelte skoler. Der er afsat et beløb svarende til 0,5 pct. af kommunens skolebudget i år og samme beløb næste år til teamfacilitatorer. Alle 70 specialklasselærere har været igennem et udviklingsforløb om at etablere samarbejde, bl.a. med familieafdelingen og PPR.

Der er endvidere sat fokus på at understøtte skoleledernes ledelsesmæssige opgaveløsning i forhold til at støtte skolens egen kompetenceudvikling. Endelig er der på det forebyggende område afsat midler til en særlig indsats i sundhedsplejen allerede i barnets første år for at understøtte forældre, som måtte have behov for noget sådant.

Der er etableret inklusionsfremmende initiativer ved, at ressourcerne er lagt ud til skolerne, hvor der derpå for skolerne er et takstbeløb på 160.000 kr. for hver elev, en skole sender i specialklasse.

Det menes at have haft stor betydning for omstillingen, at teamfacilitatorernes lokale funktioner sammen med AKT-lærere og læsevejledere er bragt i spil. Ledelsesmæssig opmærksomhed på undervisning og pædagogisk praksis skærper udviklingen, og PPR er også blevet en aktiv medspiller. Skolerne efterspørger i forhold til PPR det didak- 
tiske, og man søger at imødekomme det. Der er endvidere sat fokus på de ydelser, som skolerne efterspørger, i forhold til de tidligere, traditionelle PPR-funktioner.

Man har udnyttet de nye regler om lærernes arbejdstid til at fordre fuld tilstedeværelse med mulighed for individuelle aftaler om forlægning af arbejdet, fixtid og flextid.

Det opleves, at forældrene er glade for inklusionen. Skoleledere fortæller således, at nogle forældre gerne vil have at vide, hvordan deres børn fortsat kan gå i almenklasser. Hvad almenforældrene angår, har der været afholdt møder for skolebestyrelserne, hvor en ekstern ekspert har formuleret tre statements, så forældre ved, hvad de skal have fokus på. Der har ikke været forældreklager til hverken den kommunale forvaltning eller til Klagenævnet.

Brugen af ressourcer til supplerende undervisning, anden faglig støtte og inklusionsfremmende foranstaltninger er fuldstændigt delegeret til skolelederne.

Forvaltningsmæssige ændringer i kommunen i starten af 2015 bekymrer dog. Man frygter, at der ikke vil blive den opmærksomhed fra forvaltningens side på skolerne, man har været vant til.

\section{PPR}

PPR-lederen beskriver en udviklingsproces, hvor der er sket en ændring af intensiteten i arbejdsopgaverne, hvor PPR har en dobbelt opgave: 1) vurdering af enkelte børn og 2) konsultative forløb. PPR-medarbejdernes fokus er nu primært på konteksten i skolen og undervisningsmiljøet. PPR-lederen vurderer, at det er lykkedes at få antallet af pædagogisk-psykologiske vurderinger ned, samt at mere arbejdskraft går med konsultativt arbejde.

PPR-medarbejderne har arbejdet med læreres og pædagogers relationelle og klasseledelsesmæssige kompetencer, hvor der skal tænkes og reflekteres mere didaktisk. Efteruddannelsen ved PPR tilrettelægges med henblik på at opkvalificere fagpersonerne til at arbejde tættere sammen i et pædagogisk-didaktisk felt. Endvidere arbejdes der på, at supervision kan tilrettelægges, således at PPR tager et medansvar for fokuspersonens/fokusgruppens og skoleledelsens mål med og udbytte af supervisionen.

Det er PPR-lederens opfattelse, at lærerne i større grad ønsker hjælp af fag-faglig karakter. Det nævnes, at det fortsat kan være en udfordring, når lærerne ønsker, at PPRmedarbejdere skal være med i praksis i klasserne. Dermed menes ikke, at PPRmedarbejderne skal rådgive om selve den faglige del af undervisningen. Det påpeges, at PPR's opgave er at understøtte lærerne i at optimere deres kompetencer i forhold til relationer, klasseledelse og didaktik.

Tildelingen af ressourcer til opgaver i skolen foregår centralt og decentralt. Den centrale del forestås af et visitationsudvalg, der består af skolechef, børnechef, forebyg- 
gelseschef samt ledere fra Børne- og Familieafdelingen, Sundhedsplejen og PPR. Her træffes bl.a., på baggrund af indstilling fra PPR, beslutning om enkeltelevers optag i specialklasse. Skolelederen spiller her en aktiv rolle, bl.a. fordi der til eksklusion er knyttet et takstbeløb på kr. 160.000. Decentralt - på skolen - visiteres al specialundervisning og alle inklusionsindsatser i et kompetenceforum, hvor skoleleder og PPR er faste deltagere, mens socialrådgiver og sundhedsplejerske deltager hver tredje gang. Rammen for disse opgaver ligger i, at alle ressourcer til området er udlagt til den enkelte skole, bl.a. med afsæt i socioøkonomiske forhold.

I forhold til samarbejdet med skoleafdelingen er de tidligere afstemningsmøder afskaffet. PPR deltog herefter i et refleksions- og planlægningsforum med skolechef og skoleledere. PPR deltager ikke længere i møderne i refleksions- og planlægningsforummet. Der er derfor ikke længere et formaliseret samarbejde mellem PPR og Skoleforvaltningen. Det er PPR-lederens ønske, at der etableres et tættere samarbejde med skoleafdelingen.

Der er udarbejdet samarbejdsaftaler mellem de enkelte skoler og PPR. Der er blevet afholdt møder mellem PPR og de 12 skoleenheder, hvor opgavernes indhold og mængde konkret er blevet aftalt. Det opleves, at ønsker til PPR varierer fra skole til skole, hvorfor der er udarbejdet en forpligtende aftale og mål for den enkelte skole. Der er på baggrund af skolechefens ønske udarbejdet en fælles opgavebeskrivelse for PPR's samarbejde med skolerne.

I forhold til det kommende år mener PPR-lederen, at der fortsat vil være stor fokus på inklusion. Arbejdet med skolereformen og L409 (lovindgrebet af 26. april 2013, hvor Regeringen og KL aftalte præcise detaljer omkring lærernes arbejdstid) skal endvidere tilpasses, således at skolerne har en reel mulighed for at arbejde med de mange nye udfordringer. 


\section{Kommune E}

\begin{tabular}{|l|l|}
\hline Kommunetype & Mellemstor landkommune \\
\hline Antal folkeskoler 2015 & 4 (på 11 matrikler) \\
\hline Antal frie skoler 2015 & 12 \\
\hline Andel af elever i frie skoler 2015 & 22,8 pct. \\
\hline Antal specialklasser 2013-2015 & $32-30-21$ \\
\hline Antal specialskoler 2013-2015 & $0-0-0$ \\
\hline Nettodriftsudgifter pr. elev 2012-2014 & $69.250 \mathrm{kr} .-69.929 \mathrm{kr} .-73.390 \mathrm{kr}$. \\
\hline $\begin{array}{l}\text { Endring nettodriftsudgifter 2012-2013 } \\
\text { Endring nettodriftsudgifter 2013-2014 }\end{array}$ & 1,0 pct. \\
Ændring nettodriftsudgifter 2012-2014 & 4,9 pct. \\
\hline Socialøkonomisk indeks 2015 & 1,16 \\
\hline $\begin{array}{l}\text { Udgift pr. elev i forhold til socialøkono- } \\
\text { misk indeks }\end{array}$ & 4.000 kr. \\
\hline Inkluderet andel 2010 & 92,0 pct. \\
\hline Inkluderet andel 2013-2015 & 94,3 pct. - 95,6 pct. - 96,5 pct. \\
\hline
\end{tabular}

\section{Skoleforvaltningen}

Inklusion har været på dagsordenen siden 2010, hvor kommunen meldte sig som en af 16 kommuner til KL's inklusionsundersøgelse og fik udarbejdet en rapport. På baggrund af denne rapport blev der nedsat en styregruppe, som har udarbejdet en kommunal handleplan for inklusionstiltag i perioden 2011-16. Handleplanen går på elevernes faglige udvikling, lærerkompetencer, visitation, samarbejde på tværs af sektorer, styring af økonomi, politisk ansvar - holdning og kultur - og ledelsesansvar.

I 2011 besluttede kommunalbestyrelsen en skolestrukturændring, hvor otte skoler skulle nedlægges og de resterende lægges sammen til i alt fire skoler. Hertil kom, at 80 af tidligere 300 kommunale specialklassepladser pr. 1. august 2011 skulle nedlægges. Den fulde strukturændring er opnået i 2014.

I 2013-14 har kommunen udarbejdet fælles kommunale retningslinjer med definitioner, visioner og mål for inklusion på dagtilbuds- og skoleområdet. Retningslinjerne er udarbejdet og implementeret $\mathrm{i}$ et samarbejde med distriktslederne på skoleområdet og områdelederne på dagtilbudsområdet. Kommunen har ønsket størst mulig lokal tilgang til opgaveløsningen, hvorfor hver skole har udarbejdet sin definition. Kommunen har i 2014 udarbejdet en pendant på dagtilbudsområdet, hvor inklusionsprocenten er steget fra 96 pct. til 98 pct. 
Der er økonomiske incitamenter for inklusion. Hvis en skole vil ekskludere en elev til specialklasse eller specialskole, skal skolen betale 100.000 kr. pr. år pr. elev. Hvis en skole modsat tager en ekskluderet elev hjem, får de en inklusionstakst på 270.000 kr. til at etablere en inkluderende undervisning. Skolerne kan få ekstra midler, hvis der er tale om elever med ekstraordinært store vanskeligheder. Al økonomi var i 2013 lagt ud, når det gjaldt elever med generelle indlæringsvanskeligheder. Fra 2014 er hele økonomien lagt ud, og det er pointeret, at det er vigtigt at styrke almenundervisningen.

Kommunen udnytter de nye regler om lærernes tjenestetid til at kræve fuld tilstedeværelse på skolerne. Man forventer, at lærerne kommer mere i dialog med hinanden, hvad der vil skabe et bedre tilbud gennem bedre overleveringer, ligesom det vil understøtte det tværfaglige. Egentiden er ikke længere hellig, der skal være mere fællesskab. Der er i 2015 et ønske om at have fokus på at udvikle mulighederne i forbindelse med skolereformen og arbejdstidsreglerne.

Det opleves, at forældrene til de inkluderede elever generelt er meget tilfredse. Tilfredsheden synes at være størst hos forældre til elever, der kommer fra specialtilbuddene i andre af regionens kommuner, mens forældrene til elever, der kommer fra kommunale specialklasser, ikke helt synes, at der er tid nok til deres børn. Hvad angår forældrene til elever uden særlige behov, er der forskelle mellem distrikterne, og nogle steder fylder inklusionsproblematikken mere end andre steder. Helt overordnet ønsker kommunen at sætte fokus på de gode historier og nedtone inklusion som en "knast" i skolepolitikken.

Der er ikke foreslået specifikke fremgangsmåder for, hvordan man støtter inkluderede elevers deltagelse i faglige og sociale fællesskaber, hvordan man anvender ressourcer til supplerende undervisning og anden faglig støtte samt inklusionsfremmende initiativer. Det er helt op til den lokale skoleleder, som har førstehåndskendskab til eleverne og de muligheder, der foreligger.

\section{PPR}

I 2009 blev PPR placeret under Børn og ungeforvaltningen, hvor både socialrådgivere, PPR, sundhed, bibliotek, musik og tandpleje nu ligger. Argumentet var, at man ønskede, at alt det rådgivende personale var samlet ét sted. Fra august 2015 har socialrådgivere, sundhedsplejersker, psykologer, tale-høre-konsulenter og UU-vejledere fået faste arbejdspladser ude i distrikterne. Formålet er både, at indsatser omkring børn skal sættes i gang, inden de udvikler sig til en "sag", og at der skal ske en styrkelse af det konsultative arbejde. PPR-lederen oplever, at det tværfaglige arbejde er kommet godt i gang i 2015. I 2011 udarbejdede PPR et manifest for PPR's fremadrettede profil. Manifestet er både en konkret handleplan og en beskrivelse af visioner for PPR's funktioner, og det slår på, at 
PPR skal være et kompetence- og videnscenter og en entreprenør i udviklingen af inkluderende læringsmiljøer, hvor dette kræver specialisering og nærhed til almenområdet.

PPR har i 2014 været aktiv omkring etableringen af et kursusforløb for forældre både før og efter fødslen i forhold til at forberede dem på en ny i familien, indsigt i et spædbarns udvikling og trivsel.

PPR har endvidere i 2014 i forbindelse med kommunens besparelser udarbejdet en "servicestrategi", der skal sikre en forventningsafstemning med ledere og det pædagogiske personale i institutioner og skoler. "Servicestrategien" tydeliggør PPR's ydelser på baggrund af brugernes formulerede behov og en vægtning af det konsultative arbejde.

Visitationsprocessen består i, at der udarbejdes en pædagogisk-psykologisk vurdering, hvorefter den lokale leder vurderer, om der skal udarbejdes en indstilling til visitation. I visitationsudvalget sidder PPR-lederen, specialkonsulenten og den økonomiske konsulent. PPR peger ikke på et bestemt tilbud, men beskriver barnets behov. Hvert skoledistrikt har egne specialklasser, hvorfor det ikke skal op til visitation, hvis et barn skal i specialklasse. Det er de enkelte skoleledere, der suverænt bestemmer over specialtilbuddene i distriktet. Der skal have været et konsultativt rådgivningsforløb forud for en indstilling.

I forhold til det kommende år er det PPR-lederens forventning, at kommunen opnår en inklusionsprocent på 96, og at der sker en styrkelse af inklusionsarbejdet, både som resultat af det øgede tværfaglige samarbejde og styrkelsen af det pædagogiske personales kompetencer. Det er endvidere en forhåbning, at der kommer mere ro omkring folkeskolereformen, og at der etableres mere hensigtsmæssige tilgange og strategier $\mathrm{i}$ forhold til elever med særlige behov. 


\section{Kommune F}

\begin{tabular}{|l|l|}
\hline Kommunetype & Mindre landkommune \\
\hline Antal folkeskoler 2015 & 7 \\
\hline Antal frie skoler 2015 & 3 \\
\hline Andel af elever i frie skoler 2015 & 10,1 pct. \\
\hline Antal specialklasser 2013-2015 & $6-5-4$ \\
\hline Antal specialskoler 2013-2015 & $1-1-1$ \\
\hline Nettodriftsudgifter 2012-2014 & $63.505 \mathrm{kr} .-61.965 \mathrm{kr} .-70.222 \mathrm{kr}$. \\
\hline Endring nettodriftsudgifter 2012-2013 & $-2,4$ pct. \\
Endring nettodriftsudgifter 2013-2014 & 13,3 pct. \\
Ændring nettodriftsudgifter 2012-2014 & 10,6 pct. \\
\hline Socialøkonomisk indeks 2015 & 0,93 \\
\hline Udgift pr. elev i forhold til socialøkono- & -4.500 kr. \\
misk indeks & \\
\hline Inkluderet andel 2010 & 97,5 pct. \\
\hline Inkluderet andel 2013-2015 & 97,8 pct. - 97,6 pct. - 97,5 pct. \\
\hline
\end{tabular}

\section{Skoleforvaltningen}

I 2003 begyndte arbejdet med inklusion, da det blev pålagt skolerne at ændre fokus fra enkeltelevers vanskeligheder til fokus på, hvordan klassen fungerede. I forlængelse af dette besluttede kommunen i 2007, at alle kommunens skoler skulle arbejde med LPmodellen.

Kommunen har i 2013 udarbejdet en inklusionspolitik for området 0-18 år. Politikken har den overordnede titel "Politik for udviklende fællesskaber" og tager afsæt i værdierne fra "Sammenhængende børnepolitik og overordnede børnesyn" og har fem overordnede temaer: Inddragelse, ejerskab, kvalitet, sammenhæng og dialog. Værdigrundlaget er, at barnet/den unge er en ligeværdig medspiller i udviklende fællesskaber. Skolernes ledere er sammen med PPR ansvarlige for implementeringen af inklusionsbestræbelserne.

PPR har været en stærk medspiller i inklusionsprocesserne, og der er etableret tværfaglige team i hvert skoledistrikt. PPR har lavet oplæg på skolerne; det har været en inddragende proces, som er gentaget i foråret 2013.

Der er økonomiske incitamenter til inklusion. Distriktets børn hører til distriktsskolen, og skolerne skal betale, hvis de sender børn til andre skoler. Der er dog to mindre, centrale puljer, som skolerne kan søge midler fra, en på knapt 0,5 pct. af det samlede skolebudget til praktisk medhjælp og en pulje med i alt 38 ugentlige lektioner til udvidet specialpædagogisk bistand. 
Fra 2011 visiteres ikke længere til specialklasser, men eleverne undervises i almenklasser med særlig støtte og specialpædagogisk bistand. Det har undervejs i processen været en udfordring, at skolerne samtidig med inklusionsbestræbelserne er blevet pålagt generelle besparelser, så selv om skolelederne har været positive, kan det være svært at få personalet til at bevare en positiv holdning og ejerskab til inklusion.

Kommunen har fra 2011 en politisk beslutning om, at specialklasser gradvist skal afskaffes, og det sker ved, at der ikke længere bliver etableret 1. klasser, hvorefter specialklasserne i løbet af ni år vil være væk. En G-klasse for børn med autistiske vanskeligheder, der har været normeret til otte elever, har dog et voldsomt pres for pladser, også fra indskolingen. Når specialklasser arbejder sammen med almenklasser er der fuld bemanding på fra begge.

Det opleves, at forældre til elever med generelle indlæringsvanskeligheder er meget tilfredse og kan se en udvikling hos deres børn. Forældre til elever med en mere udadreagerende adfærd opleves ikke tilfredse med inklusionen. Kommunen er lykkedes med at få almenforældrene til at tage de gode billeder og historier til sig.

Udnyttelsen af de nye regler om lærernes tjenestetid går ud på, at der i princippet er fuld tilstedeværelsespligt, men at der er muligheder for individuelle aftaler, fx i forbindelse med efteruddannelse. Pædagogisk råd er nedlagt.

Der er ikke lagt kommunale planer for supplerende undervisning og anden faglig støtte til enkeltelever, men det er beskrevet, at man ikke må etablere nye specialklasser. Der må gerne skabes tilbud til enkeltelever eller grupper af elever, men det skal være af midlertidig karakter. Etablering af inklusionsindsatser er helt op til den enkelte skole.

Planen for de kommende år er i starten af 2015 at fortsætte den kompetenceudvikling af personalet, som byrådet har bevilget i alt knapt fem mio. kr. til, en kompetenceudvikling, hvor reflekterende team i første omgang har været i særlig fokus.

\section{PPR}

PPR-lederen refererer direkte til Børne- og Kulturdirektøren. PPR er normeringsstyret, men efterspørgselsstyret efter behov. Det er således ikke forud bestemt, præcist hvor mange timer hver enkelt skole eller institution skal have. PPR er organiseret således, at de sidder centralt, hvor de kan drøfte sager i det tværfaglige team. Hver skole og institution har en kontaktpsykolog, således at leder, lærere og pædagoger ved, hvem de skal henvende sig til. Kontaktpsykologen er gennemgående i forhold til skolen og løser almenopgaver. I mere komplekse sager vil opgaverne blive taget op i det tværfaglige team, og det vil blive vurderet, hvilke faggrupper der skal arbejde med sagen.

PPR har været særdeles aktiv i inklusionsprocessen. Man gennemførte en analyse af specialundervisningen i 2010 og udarbejdede en inklusionsfremmende styringsmodel. 
Dette har betydet, at PPR udarbejder langt færre pædagogisk-psykologiske vurderinger end tidligere og nu bruger størstedelen af tiden til rådgivning og vejledning, hvorfor de er kommet meget tættere på praksis og arbejder tæt sammen med ledelserne om udvikling af læringsmiljøer. PPR arbejder aktivt sammen med dagtilbuddene om at sikre, at børnene er klare til skolestart.

I visitationsprocessen indgår pædagogisk/administrativ konsulent, skoleleder, repræsentant fra PPR og PPR-lederen.

I 2014 deltog PPR i en arbejdsgruppe bestående af repræsentanter fra familieafdelingen, sundhedsplejen, DLF, BUPL, FOA, NVIE samt ledelsesrepræsentanter fra de syv skoledistrikter, som har udarbejdet en ramme for det videre arbejde med inklusion.

Kommunen har altid haft en lav segregeringsgrad, og det er holdningen, at antallet af inkluderede elever skal ligge på et realistisk niveau. I 2015 er inklusionsprocenten faldet lidt, og det bemærkes samtidig, at de "tungeste" sager bliver endnu tungere, idet vanskelighederne er mere sammensatte og komplicerede.

Det er på politisk plan i kommunen besluttet, at der ikke længere skal visiteres til specialklasserne. Kommunen har fortsat en autisme-klasse og en tale-klasse. Kommunen har i de senere år haft en stor stigning i ansøgninger til autisme-klassen. Specialklasserne skal gradvist nedlægges og dækker p.t. fra 6. klasse og opad.

I forhold til det kommende år er det eneste ønske fra PPR-lederen, at der skal større fokus på de tværfaglige opgaver, således at enkeltsager ikke skal over flere afdelinger i forvaltningen. PPR er i gang med at uddanne alle psykologer i LSP (Laboratorium for forskningsbaseret skoleudvikling og pædagogisk praksis), hvad der gerne skulle understøtte den målstyrede kompetenceudvikling i skoler og dagtilbud. 


\section{Kommune G}

\begin{tabular}{|l|l|}
\hline Kommunetype & Stor bykommune \\
\hline Antal folkeskoler 2015 & 36 \\
\hline Antal frie skoler 2015 & 18 \\
\hline Andel af elever i frie skoler 2015 & 18,8 pct. \\
\hline Antal specialklasser 2013-2015 & $87-74-76$ \\
\hline Antal specialskoler 2013-2015 & $3-3-3$ \\
\hline Nettodriftsudgifter pr. elev 2012-2014 & $64.893 \mathrm{kr} .-60.644 \mathrm{kr} .-62.701 \mathrm{kr}$. \\
\hline $\begin{array}{l}\text { Endring nettodriftsudgifter 2012-2013 } \\
\text { Endring nettodriftsudgifter 2013-2014 }\end{array}$ & $-6,5$ pct. \\
Ændring nettodriftsudgifter 2012-2014 & $-3,4$ pct. \\
\hline Socialøkonomisk indeks 2015 & 1,10 \\
\hline $\begin{array}{l}\text { Udgift pr. elev i forhold til socialøkono- } \\
\text { misk indeks }\end{array}$ & -1.000 kr. \\
\hline Inkluderet andel 2010 & 94,9 pct. \\
\hline Inkluderet andel 2013-2015 & 95,9 pct. - 96,4 pct. - 96,8 pct. \\
\hline
\end{tabular}

\section{Skoleforvaltningen}

Børn og ungeforvaltningen har i en årrække op til 2012 arbejdet med inklusion, og inklusionsdagsordenen har været tydelig i børn- og ungepolitikken. I november 2012 indledtes et projekt med det formål at udvikle en strategi for inklusion. Projektet blev afsluttet $\mathrm{i}$ december 2013. Kommunen definerer inklusion på følgende måde: børn og unge skal støttes til at tage aktivt del i fællesskaber, som skaber rammer og aktiviteter, der fremmer læring, sundhed og trivsel. Arbejdet med inklusion skal bidrage til at skabe motiverende læringsmiljøer, hvor børn og unge lærer endnu mere og ruster sig endnu bedre til uddannelse. En del af strategien har været etableringen af et Center for Inklusion, hvor PPR indgår sammen med specialrådgivning og børneterapi.

Som følge af en meget stor organisationsændring og restrukturering er Center for Inklusion opløst i 2014, hvad der har medført, at der i en periode har været nogen usikkerhed om håndteringen af bl.a. inklusion. Der er nu etableret tre regioner i kommunen for forvaltningsområdet Sundhed og Forebyggelse, som dækker hele 0-18-årsområdet, og der er følgelig tre børne- og ungechefer i kommunen, mens Specialrådgivningen, som tager sig af "den vidtgående specialundervisning", dvs. støtte over 12 lektioner om ugen eller specialundervisning i segregerede tilbud, ligger i forvaltningsområdet Familie og Velfærd. Det er i starten af 2015 ikke muligt at vurdere, om tilbuddene til skolerne har ændret karakter. 
Det har været væsentligt for kommunen at skabe ejerskab blandt medarbejdere og forældre til inklusion. Derfor har skolechefen været ude på alle skoler i forbindelse med introduktionen af "Den sammenhængende skoledag", som er kommunens forløber for skolereformen. "Den sammenhængende skoledag" har bl.a. til formål at sikre, at almenskolen skal kunne mere, at flere børn skal kunne være en del af det store fællesskab, og at færre skal visiteres til specialpædagogiske tilbud. Der har endvidere været en pressestrategi, som er lykkedes og har givet medvind til inklusionsstrategien. Endvidere har skolelederne spillet en væsentlig rolle i forhold til informering af medarbejdere og forældre. Det erkendes dog, at omstillingen til inklusion har haft sine udfordringer politisk og følelsesmæssigt, ikke mindst fordi samtidig med, at ressourcer skulle overføres til almenområdet, er det blevet modsvaret eller mere end modsvaret af generelle besparelser.

Der blev i januar 2014 udarbejdet en pjece med titlen: Strategi for inklusion - inkluderende fællesskaber for alle børn og unge, der kan give forældre et indtryk af, hvad inklusion er, og bl.a. har et afsnit om forældre som aktiv ressource i arbejdet med inklusion.

Der er en ressourcestyringsmodel for almenskolen og en model for specialskolerne, og der er i begge etableret en økonomisk incitamentsstruktur for inklusion. Almenskoler, der inkluderer, må beholde de penge, der ville være gået til en ekskluderende placering. Der er endvidere en socioøkonomisk pulje, der vokser, når der ekskluderes færre elever. Der har været en central garantiordning, skoler kunne søge om, men den er efter en evaluering fjernet fra 1. august 2013, således at det bliver de enkelte skoler, der skal dække udgifterne ved eksklusion.

Kapaciteten i kommunens specialtilbud justeres løbende ned. De mest specialiserede tilbud modtager elever fra omkringliggende kommuner, og der er set et fald i andelen af elever "i den lette ende", hvor de økonomiske incitamentsstrukturer har størst effekt. Fx er der nu kun tre obs-klasser mod tidligere fire. De økonomiske incitamentsstrukturer er justeret i forhold til de generelle stigninger i omkostningsniveauet. Center for Inklusion havde en rolle som den instans, der skulle tilse, at ressourcerne fulgte med eleverne og anvendtes på en god måde. Med hensyn til forskellen mellem de strategiske mål på forvaltningsniveau og lærernes overtagelse af målene har kommunen søgt at kommunikere ud, at det mange steder er gået godt, men det halter der, hvor lederen ikke er god nok til at kommunikere fortællingen.

Der har været en omfattende kompetenceudvikling. Der er læsevejledere og AKTvejledere på samtlige skoler, og der er uddannet inklusionsvejledere, hvoraf mange i øvrigt har en fortid som AKT-vejledere. Der er imidlertid også væsentlige "knaster" i omstillingsprocessen. Besparelser på takstbeløb og ændring af arbejdstidsaftaler for læ- 
rerne har givet store problemer med modstand mange steder fra forældre, personale og af og til også fra ledere. Der er tillidsfolk, som har villet skabe og have en anden dagsorden og søger at lave alliancer med forældrene. Der har været meget debat i de lokale medier.

Kommunen har villet benytte de nye regler om lærernes tjenestetid ved at se på tidsforbrug og tage det ledelsesrum, der nu ligger. Man har ikke villet lave en lokalaftale. Der er satset på tilstedeværelse 227 dage om året, og formålet er, at man bl.a. af hensyn til inklusionsopgaven kan opnå et mere teambaseret og tværfagligt arbejde i et dynamisk arbejdsfællesskab. Der er mange lærere, som gerne vil, men også en del, der har protesteret højlydt.

Med hensyn til supplerende undervisning og anden faglig støtte til enkeltelever er ansvaret lagt ud til skolelederne, men det er fra kommunens side pointeret, at man skal tænke væk fra individorientering - to timer til den elev og tre timer til den elev - men i stedet tænke i timer til et miljø eller et hold, hvor eleverne kan lære og trives, herunder arbejde med mere end én voksen pr. klasse. Når det gælder inklusionsindsatser, er ansvaret også skolelederens, men det har været udmøntet i et samarbejde med Center for Inklusion.

Ved starten af 2015 er der usikkerhed om, hvad det kommende år vil bringe, men der er fortsat stærkt fokus på at undgå placeringer i specialtilbud gennem inkluderende indsatser i dagtilbud og skole.

\section{PPR}

I 2012 blev Center for Inklusion et af fire centre i Børn- og familieafdelingen. Centeret bestod af tre faglige enheder: PPR, specialrådgivning og børneterapi. Centeret vurderede, hvilke børn der havde behov for specialundervisning, og varetog opgaver for børn med funktionsnedsættelser og handicap. Endvidere blev inklusionsfaglig viden stillet til rådighed for kommunen, både inden for praksis, lovgivning og forskning.

Det var Center for Inklusion, som spillede en central rolle i kommunens udvikling af en samlet inklusionsstrategi. Center for inklusion gav sparring til professionelle voksne i forhold til tilrettelæggelse af læringsmiljøet, bidrog med kompetenceudvikling af det pædagogiske personale og gav psykologiske samtaleforløb til folkeskolens ældste elever i forhold til øget trivsel og fastholdelse i uddannelsessystemet.

Skoleledere og PPR-psykologer samarbejdede med forældre om indstilling til specialpædagogiske skoletilbud. Forud for en indstilling havde distriktspsykologen haft sparring med en faglig koordinator i visitationsenheden med henblik på at afdække, om der fortsat var uafprøvede muligheder i skolens eget regi. Indstillinger behandles af et centralt visitationsudvalg bestående af faglige koordinatorer fra Center for Inklusion. Fra 
2014 er det skolelederne og Specialpædagogisk Rådgivning, PPR, der står for visitationen.

I 2014 havde PPR en aktiv rolle i indførelsen af den sammenhængende skoledag. PPR-lederen havde endvidere været tovholder på udarbejdelsen af den kommunale inklusionsstrategi på børn- og ungeområdet. I forhold til udarbejdelsen af inklusionsstrategien blev en arbejdsgruppe nedsat med repræsentanter fra de forskellige pædagogiske personalegrupper og forældre. Der blev arbejdet ud fra følgende fem temaer: 1) Afsæt i børn og unges styrker og potentialer, 2) Udvikling af forpligtende fællesskaber, 3) Forældre er en aktiv ressource, 4) De professionelle samarbejder, og 5) Ledelsen er nøglen. Implementeringsprocessen er midlertidigt gået i stå grundet ændringen af forvaltningsstrukturen på skoleområdet.

Generelt har der været nedgang i antallet af indstillinger henover de seneste år. Kommunen har stort set nået målene i økonomiaftalen. Der arbejdes på en bevægelse fra specialområdet mod mindre indgribende tilbud. Specialpsykologer giver sparring til almenpsykologer, så specialviden bringes i spil i den almene kontekst.

I forhold til PPR's organisatoriske placering i kommunen er der sket store ændringer medio 2014. Center for Inklusion er nedlagt, og PPR som selvstændig enhed er ophørt. De tidligere PPR-medarbejdere er blevet fordelt på fire områder, tre regioner, som har hver sin leder og med overordnet placering i forvaltningen Familie og Velfærd, samt en specialrådgivning, som arbejder i det specialiserede småbørnsområde og med indsatser i skoleregi. I forhold til reorganisering af PPR så træder regionernes forebyggelsesområder ind i en god samklang med det specialpædagogiske, idet der arbejdes for en skole for alle børn.

Som forventninger til fremtiden nævnes, at reorganiseringen har været vanskelig, og at savnet efter Center for Inklusion er stort. Det er dog således, at den nye organisering er ved at finde sit leje, og at implementeringen af inklusionsstrategien fortsætter. Der arbejdes med strategien alle steder, såvel i kommunens regioner som i specialrådgivningen, der er dog en usikkerhed omkring, hvem der har det overordnede ansvar for strategien. 


\section{Kommune $\mathrm{H}$}

\begin{tabular}{|l|l|}
\hline Kommunetype & Mellemstor landkommune \\
\hline Antal folkeskoler 2015 & 12 \\
\hline Antal frie skoler 2015 & 3 \\
\hline Andel af elever i frie skoler 2013 & 11,5 pct. \\
\hline Antal specialklasser 2013-2015 & $6-6-6$ \\
\hline Antal specialskoler 2013-2015 & $1-1-1$ \\
\hline Nettodriftsudgifter pr. elev 2012-2014 & 81.049 kr. -78.558 kr. - 83.215 kr. \\
\hline $\begin{array}{l}\text { Endring nettodriftsudgifter 2012-2013 } \\
\text { Endring nettodriftsudgifter 2013-2014 } \\
\text { Ændring nettodriftsudgifter 2012-2014 }\end{array}$ & $-1,3$ pct. \\
\hline Socialøkonomisk indeks 2013 & 2,7 pct. \\
\hline $\begin{array}{l}\text { Udgift pr. elev i forhold til socialøkono- } \\
\text { misk indeks }\end{array}$ & 1,07 \\
\hline Inkluderet andel 2010 & -3.000 kr. \\
\hline Inkluderet andel 2013-2015 & 92,3 pct. \\
\hline
\end{tabular}

\section{Skoleforvaltningen}

Kommunen startede i 2007 med at tale om rummelighed. I 2010 gik man over til at tale om inklusion, og i maj 2012 vedtog kommunen en politik for inklusion og tidlig indsats. Kommunen har defineret sin vision for inklusion på følgende måde: Alle børn og unge oplever mulighed for at være aktive og ligeværdige deltagere i anerkendende og inkluderende fællesskaber i skole- og dagtilbud med fokus på læring og udvikling.

Kommunen har med afsæt i visionen og forskning på området udarbejdet tre strategiområder og hovedtyper af indsatser for inklusion. Første strategi handler om faglig, social og personlig udvikling for alle som et fælles ansvar. Den anden strategi handler om udviklingsorienterede miljøer, hvilket vil sige, at alle børn skal tilbydes udviklingsmuligheder og undervisning, der svarer til deres forudsætninger og behov, og som samtidig rummer udfordringer for den enkelte. Den tredje strategi for inklusion handler om brobygning og helhedstænkning, hvilket betyder, at forvaltning og ledere af de enkelte enheder ser sig selv som en del af et samlet fællesskab, der arbejder hen imod de samme mål.

Ejerskab til inklusionsstrategien er skabt ved, at der i hele processen har været dialogfora, og der har været etableret arbejdsgrupper, hvor man har inddraget lærere og forældre. Der er etableret en TRIM-model (Tid, Ressourcer, Indsats og Mål) for perioden 
2013 til 2016, som giver rammer for, hvordan implementering sker lokalt, og hvordan der måles på effekt af politikkerne.

Der er skabt økonomiske incitamenter for inklusion, ved at almenskoler betaler et grundbeløb på 180.000 kr., hvis de får godkendt en visitation. Når en elev overgår fra et specialtilbud til en almenskole, tildeles skolen samme ressource. I omstillingen til inklusion har man kunnet trække på en dygtig læsekonsulent, og der er uddannet faglige vejledere.

Det har været en udfordring, at det i 2013 kun var 9,5 pct. af samtlige lærere, der havde en specialpædagogisk uddannelse, og der har derfor været behov for en omfattende kompetenceudvikling. Der er satset på at få faglige vejledere med ledelsesmæssig legitimitet. Der er også satset på en øget vidensdeling mellem specialtilbud og almenundervisningen samt på, hvordan PPR kan bringes mere i spil. Satsningerne skal omsættes til realiteter. Der er i øvrigt udarbejdet et omfattende skriftligt materiale med de samlede kommissorier for medarbejdergrupperne, visioner for vejlederrollerne, fælles forstålser af trivsel samt en drejebog for implementering af folkeskolereformen.

Med hensyn til økonomiske incitamenter blev der i 2013 etableret en grundtakst på 180.000 kr. pr. elev, men fra 1. januar 2015 er alt lagt ud, så skolerne skal betale den faktiske omkostning for segregerede elever.

Hvad angår det at få de strategiske mål helt ud i klasseværelserne, anses folkeskolereformens tale om læringsmål for at være vigtige, men mange lærere synes, at det er svært, og det arbejdes der betydeligt med. En vigtig faktor er skole- og dagtilbudsafdelingens konsulentteam. Der arbejdes med vidensdeling i vejledernetværk, og der er en særlig indsats omkring teamarbejdet.

Det er et princip, at ressourcerne til inklusion skal følge med ud i undervisningen. Alt er lagt ud, men det giver ikke sig selv, og derfor har forvaltningen dialogmøder med skoler og ledelser hvert år, og PPR er en aktiv medspiller i at afdække, hvordan behovet ser ud. Forvaltningen og PPR skal også en gang imellem udfordre, både i forhold til at børn burde have et mere indgribende tilbud og det modsatte. Der er nedfældet information til forældrene om hvilke klagemuligheder, der er, dels i en folder, dels på kommunens hjemmeside. PPR's funktion har generelt været under ændring, og den er i 2014 omorganiseret, så PPR er underlagt en afdelingsleder.

I forhold til de inkluderede elevers forældre opleves det, at de fortsat er lidt usikre. Forældre til elever uden særlige behov udviser fortsat en meget kritisk holdning til inklusion.

De nye regler om lærernes tjenestetid er blevet brugt til at udnytte den langt større fleksibilitet i arbejdstid og undervisning, og der er et særligt fokus på at få teamsamarbejdet til at fungere. 
Der er i inklusionspolitikken nævnt nogle konkrete indsatsområder, når det gælder supplerende undervisning og anden faglig støtte til enkeltelever, herunder inddragelse af it og vægtlægning på læring, men ellers er det helt op til skolen at administrere det. Indsatser og ressourceforbrug i forhold til inklusionsindsatser ligger i en bevilling, som betyder, at der er afsat 1,15 lærere til hver time/klasse, og skolelederen kan så disponere med fx holddannelse.

Ved starten af 2015 forventer skolechefen, at inklusionsprocessen fortsætter, og at man arbejder med "Synlig læring" - lærende elever og lærende skoler.

\section{PPR}

PPR var i 2013 placeret under Velfærdsforvaltningen, som dækker hele 0-18-årsområdet og refererer til skole- og dagtilbudschefen. I 2012 blev hele forvaltningen samlet geografisk, og argumenterne for dette var, at der skete flere og flere overlap og for meget sammenfald af sagsforløb i forskellige enheder. I 2014 skete et skifte i ledelsen af PPR, hvor kommunens specialpædagogiske konsulent varetog den faglige ledelse, og PPR er nu placeret i Skole og dagtilbudsafdelingen. Fra november 2014 har PPR fået en ny faglig leder.

I 2013 arbejdede PPR fortsat meget traditionelt, hvor 80 pct. af deres arbejde var at udarbejde pædagogisk-psykologiske vurderinger. Der blev dog arbejdet på, at medarbejdernes arbejde skulle deles ligeligt mellem pædagogisk-psykologiske vurderinger og konsultative tiltag.

På baggrund af skolernes ønsker og lærernes behov har skole- og dagtilbudschefen og lederen af PPR drøftet, hvorvidt personalet på PPR har den rigtige sammensætning. De vurderer, at der er behov for praktisk pædagogisk erfaring og kendskab til didaktik for at kunne udføre de konsultative opgaver og føre dem helt ud i daglig praksis. Man ønsker i samme forbindelse, at psykologerne får en mere synlig rolle ude på skolerne.

I januar 2013 udarbejdede Skole- og dagtilbudsafdelingen et regelsæt om visitation og revisitation på skoleområdet. Visitationen har som værdigrundlag, at man under behørigt økonomisk hensyn skal vurdere muligheder og rammer for at opfylde barnets behov i forhold til fire værdier: Forbundethed, bevægelse, kontrol og anerkendelse. Det er skolelederen, der suverænt træffer beslutning om iværksættelse af specialpædagogisk bistand i almenklassen. Det centrale visitationsudvalg, der består af konsulenten fra Skole- og dagtilbudsafdelingen og PPR-leder, træffer på baggrund af skolelederens indstilling beslutning på kommunalbestyrelsens vegne, når det gælder visitation til specialklasser, specialskoler, anbringelsessteder og regionale tilbud. Visitationen lægger vægt på, at børnene og de unges udviklings- og undervisningsbehov bliver tilgodeset ved lokale tilbud, og tilbyder derfor normalt det nærmeste. 
PPR gik i 2014 i gang med at udarbejde et ydelseskatalog for PPR's opgaver. Dette arbejde er ophørt med ansættelsen af den nye leder.

Der er i 2014 sket et fald i antallet af børn, der segregeres. Til gengæld nævnes det, at specialtilbuddene melder om, at de oplever, at de segregerede elever har væsentligt større vanskeligheder. Der revisiteres kun til specialtilbud, hvis det er fagligt begrundet, det er funktionsniveauet, der er afgørende, men den ekskluderende undervisning forsøges undgået.

I forhold til forventninger til det kommende år er det PPR-lederens ambition at få samlet PPR-medarbejderne og få styrket samarbejdet mellem PPR og Skole- og dagtilbudsafdelingen.

\section{Kommune I}

\begin{tabular}{|l|l|}
\hline Kommunetype & Mellemstor landkommune \\
\hline Antal folkeskoler 2015 & 13 \\
\hline Antal frie skoler 2015 & 15 \\
\hline Andel af elever i frie skoler 2015 & 31,1 pct. \\
\hline Antal specialklasser 2013-2015 & $14-14-16$ \\
\hline Antal specialskoler 2013-2015 & $0-0-0$ \\
\hline Nettodriftsudgifter pr. elev 2012-2014 & $74.525 \mathrm{kr} .-71.326 \mathrm{kr} .-77.061 \mathrm{kr}$. \\
\hline Æendring nettodriftsudgifter 2012-2013 & $-4,3$ pct. \\
Ændring nettodriftsudgifter 2013-2014 & 8,0 pct. \\
Ændring nettodriftsudgifter 2012-2014 & 3,4 pct. \\
\hline Socialøkonomisk indeks 2015 & 0,94 \\
\hline Udgift pr. elev i forhold til socialøkono- & -1.250 kr. \\
misk indeks & \\
\hline Inkluderet andel 2010 & 91,8 pct. \\
\hline Inkluderet andel 2013-2015 & 96,3 pct. - 96,0 pct. - 96,8 pct. \\
\hline
\end{tabular}

\section{Skoleforvaltningen}

I 2006, umiddelbart før strukturreformen, begyndte det forberedende arbejde for skole, dagtilbud og det sociale område. Der blev udarbejdet en skolepolitik for kommunen som led i en sammenhængende børnepolitik, hvor der blev lagt stor vægt på det decentrale ejerskab, som er støttet ved, at skolechefen afholder dialogmøder med skolebestyrelserne mindst to gange om året. Der har været afsat et årligt beløb svarende til 0,2 pct. af det samlede skolebudget til kompetenceløft. I 2011 blev der defineret politiske målsætninger for bl.a. inklusion, herunder hvilken betydning det har for de enkelte skolers praksis. 
Den politiske målsætning lyder som følger: Der skal ske en løbende udvikling af normalområdet, så det kan omfatte flest mulige børn og unge, gennem lokal indsats, samarbejde og fællesskaber. Der skal være lokale tilbud, hvor voksne kan understøtte og vejlede med udgangspunkt i barnets og den unges relationer til omverdenen.

Der er lagt en strategi for inklusion, der hviler på fire søjler: Politisk ejerskab og arbejde med holdninger og kultur hos medarbejdere og forældre. Der er tale om en gradvis proces, hvor der satses på fælles kompetenceudvikling. Skolerne har med udlægning af ressourcer pr. elev mulighed for at etablere forskellige former for redskaber til at imødekomme kravet om øget inklusion. Dette kan fx være opbygning af et kompetencecenter på skolen, som lærerne og pædagogerne kan trække på, og det kan være kompetenceudvikling af personale. Der blev udlagt ressourcer til skoler for et år ad gangen med start fra skoleåret 2013/14. Inklusion ses sammen med folkeskolereformen, hvor den længere skoledag ses som en fordel.

Der er ikke foretaget hjemtagelser fra specialtilbud, men der er satset på, at færre elever visiteres til specialtilbud gennem opbygning af en mere inkluderende praksis i almenklasserne. I skolernes praksis er forskellen, at der arbejdes mere med holddannelse, og ledelser og personale har kunnet flytte ressourcer til forebyggende arbejde.

Det erkendes, at der har været udfordringer i forbindelse med implementering af en inkluderende praksis. Der har været lærere, der var imod, men de største problemer har ligget i modstand fra grupper af forældre til elever uden særlige behov mod inklusion af elever med udadreagerende adfærd, og det er et særligt problem i en kommune med mange frie skoler. Det opleves dog i 2015, at der er en øget forståelse for inklusion blandt forældrene.

Udlægningen af ressourcer til skolerne gennemføres rullende et år ad gangen fra starten af skoleåret 2013. Skolerne har i skoleårene 2013-14 og 2014-15 afregnet med 125.000 kr. pr. segregeret elev, men fra 2015 vil afregningen være på 204.000 kr., hvad der svarer til afregningen af 12 støttelektioner i kommunen, som dermed er i overensstemmelse med lovgivningen på området. Det anerkendes, at der vil kunne opstå særlige udfordringer for kommunens mindste skoler, men det vil man løse ad hoc med ekstratildelinger fra centralt hold.

Man har søgt at bremse visitation til eksterne specialtilbud og har også hjemtaget elever, men det er sket i fred og fordragelighed og er især sket på talesprogsområdet. Der er en lille udvidelse af antallet af elever i specialklasser, men det skyldes, at de nu rummer elever, man tidligere ville have sendt ud. Det er nu også blevet en del af kulturen, at eleverne kan blive en del af almenundervisningen. I 2014 er der etableret et læsetilbud i kommunen, hvis opgave dels er at tilbyde et undervisningsforløb på 4.-6. klassetrin til 8-10 elever med store læsevanskeligheder, dels at være kompetencecenter på læ- 
seområdet for alle kommunens skoler. Selve undervisningsforløbet i læsetilbuddet foregår som en vekselvirkning mellem intensiv læseundervisning i den lille gruppe med særligt uddannede lærere og undervisning i egen hjemklasse, hvor lærerne tilknyttet læsetilbuddet superviserer almenklassens lærere. Dette tilbud opleves meget positivt af alle.

Omstillingsprocessens største udfordringer har været at få kompetenceudviklet personalet og få nogle af skolelederne ind i opgaven og tage ansvar. Personalet står ikke længere med paraderne oppe, men de kan synes, at det er svært, og de efterspørger hjælp. For specialtilbuddenes vedkommende er der blevet lagt mere vægt på det faglige indhold, og at der er tale om et undervisningstilbud.

Kommunen udnytter de nye regler om lærernes tjenestetid til at søge at få kappet forholdet mellem undervisning og forberedelse og i stedet se på opgavens art. Der skal være differentieret tidsforbrug, og der vil skulle ses på belastningsgraden. Lederne skal holde fast, og de skal have kendskab til den pædagogiske praksis på skolen.

Hvad angår supplerende undervisning og anden faglig støtte til enkeltelever, er indsatsen helt op til skolelederen. Det samme gælder for inklusionsindsatser. Der lægges dog vægt på, at skolerne altid bør have en reserve, der kan sættes ind, når der opstår særlige problemer.

\section{PPR}

PPR har siden 2007 været placeret i Børn og ungerådgivningen, som er en selvstændig forvaltningsenhed. Under Undervisning (skoleforvaltningen) hører specialundervisningskonsulenterne. PPR's virke omfatter konsultative forløb, sager om enkeltforløb, herunder pædagogisk-psykologisk vurdering, møder med lærere og forældre. Afgørelser med indstilling til et tilbud svarende til 12 ugentlige lektioners støtte eller mere træffes i fagsekretariatet for Undervisning på baggrund af pædagogisk-psykologiske vurderinger foretaget af PPR. Der er ingen planer om ændringer af organiseringen. PPR oplever imidlertid, at processen omkring afgørelserne kan være svær for forældrene, og PPRlederen har derfor et stort ønske om, at samarbejdet mellem Undervisning og PPR omkring visitationen/afgørelserne styrkes.

PPR har arbejdet konsultativt siden 2007, men det har været en udfordring, at PPR var forud for lovgivningen, og nogle skoleledere har haft svært ved at anerkende konsulenternes faglighed, da de pr. tradition foretrak psykologer. PPR-lederen har været i dialog med skolelederne om, hvorfor de ønskede en psykolog, og hvilke behov de egentlig havde. Det har medført, at skolelederne nu er tilfredse med konsulenternes faglighed. PPR er i øvrigt efterspørgsels- og lønsumsstyret, hvad der giver et naturligt fokus på be- 
hov og kvalitet. Der er udarbejdet en fast skabelon for samarbejdet mellem PPR og skoler, der sikrer og dokumenterer kvalitetsstandarden.

Skolerne har en kontaktmedarbejder på PPR, som fordeles på skolerne efter, hvor de passer bedst, et år ad gangen.

Visitationsprocessen starter med, at PPR udarbejder en pædagogisk-psykologisk vurdering efter at have arbejdet med vurdering af eleven, talt med lærere og forældre, foretaget observationer mv., hvorefter selve visitationen sker i skoleafdelingen. Visitationsprocessen er dermed delt mellem to forvaltningsenheder, hvilket kan gøre processen svær for forældrene. Det er et stort ønske, at samarbejdet mellem skoleafdelingen og Børn- og ungeafdelingen skal udbygges i forhold til visitation.

Pr. 1. januar 2014 er der udarbejdet en ny kvalitetsstandard specifikt for det forebyggende arbejde omkring børn og unge, hvor alle involverede parter omkring barnet samles, således at den indsats, det vælges at sætte i gang, aftales i samarbejde med relevante involverede parter. Forældre opfattes her som en involveret part. Inddragelsen og involveringen af forældrene i samarbejdet omkring barnet er et meget centralt perspektiv i kvalitetsstandarden.

PPR føler, at de er godt på vej i forhold til inklusionsprocessen. De har et outcomefokus, hvor de stiller spørgsmålet: Virker det? I forhold til det forebyggende arbejde vurderes der efterfølgende på: Er der en effekt af arbejdet, og har indsatserne skabt merværdi?

PPR-medarbejderne er fortsat fordelt på skoler og dagtilbud bestemt af demografiske vilkår. Det er et ønske, at PPR bliver mere efterspørgselsstyret, da det vil medføre, at konsulenterne bliver brugt mere optimalt, samtidig med at det vil optimere samarbejdet med de enkelte ledelser.

Der er en forventning om, at målene i kommuneaftalen nås. Det er dog en udfordring i forhold til organiseringen og sparringen i samarbejdet mellem PPR og skolerne. Det er skolernes folk, der vurderer, og det er skolechefen, der styrer økonomien. PPR kan så tage en sag op, og midt i forløbet kan sagen sendes til visitation, selvom PPR vurderer, at der slet ikke er arbejdet nok med sagen, men beslutningen træffes centralt på de enkelte skoler. Visitationsprocessen er ikke ændret.

Hvad angår forventninger til det kommende år gælder, at der er fokus på at få det nye børne- og familiehus rigtigt i gang. Huset skal bruges til forebyggelsesaktiviteter. Det er ambitionen, at husets lokaler også skal benyttes af skolerne i forbindelse med møder. 


\section{Kommune J}

\begin{tabular}{|l|l|}
\hline Kommunetype & Mindre landkommune \\
\hline Antal folkeskoler 2015 & 4 \\
\hline Antal frie skoler 2015 & 5 \\
\hline Andel elever i frie skoler 2015 & 30,5 pct. \\
\hline Antal specialklasser 2013-2015 & $8-7-6$ \\
\hline Antal specialskoler 2013-2015 & $2-2-2$ \\
\hline Nettodriftsudgifter pr. elev 2012-2014 & 72.500 kr. $-67.255 \mathrm{kr} .-69.222 \mathrm{kr}$. \\
\hline $\begin{array}{l}\text { Endring nettodriftsudgifter 2012-2013 } \\
\text { Endring nettodriftsudgifter 2013-2014 } \\
\text { ÆEndring nettodriftsudgifter 2012-2014 }\end{array}$ & $-7,2$ pct. \\
\hline Socialøkonomisk indeks 2013 & $-4,5$ pct. \\
\hline $\begin{array}{l}\text { Udgift pr. elev i forhold til socialøkono- } \\
\text { misk indeks }\end{array}$ & 1,04 \\
\hline Inkluderet andel 2010 & 1.000 kr. \\
\hline Inkluderet andel 2013-2015 & 91,7 pct. \\
\hline
\end{tabular}

\section{Skoleforvaltningen}

Kommunen har siden 2007 bl.a. med støtte fra satspuljemidler iværksat en række initiativer på skoleområdet, der alle har haft til formål at øge inklusionen i folkeskolerne og nedbringe antallet af elever, der henvises til undervisningstilbud uden for den almene undervisning. Fra skoleåret 2011/12 har der været mulighed for yderligere kvalitetsmæssige løft, da der afsættes et årligt beløb på 7 mio. kr. svarende til 4,6 pct. af det samlede skolebudget til generel udvikling inden for folkeskoleområdet. Beløbene er en del af provenuet ved en skolestrukturændring, hvor fem ud af ni skoler blev nedlagt.

Kommunens definition af inklusion lyder som følger: Inklusion er den dynamiske, vedvarende proces, hvori skolen øger mulighederne for tilstedeværelse, oplevelse af fællesskab, aktiv deltagelse og højt læringsmæssigt udbytte for alle elever. I denne proces tages der særligt hensyn til de elever, der er i farezonen for marginalisering, eksklusion og lavt fagligt udbytte.

Fra 2011 er der arbejdet med initiativer som: Etablering af videnscentre, ledelsesudvikling, ny tildelingsmodel for ressourcer, ændring af PPR's funktion, kompetenceudvikling hos lærere og pædagoger, Cooperative Learning, ansættelse af to undervisningsassistenter/inklusionsassistenter på hver skole og projekt "Op lille Hans", sidstnævnte med det formål at mindske elevfravær. Derudover er der igennem de seneste to år gennemført et pilotprojekt med familieklasser. 
De omkringliggende kommuner, der benytter kommunens specialskoler, har hjemtaget en del elever. Kommunen selv flytter ikke elever tilbage til distriktsskolen, men har satset på at visitere færre. Dette medfører, at kommunen hele tiden arbejder bevidst på at tilpasse kapaciteten på specialområdet.

PPR's funktion er ændret, så de i højere grad er blevet sparringspartnere for skolerne. Psykologerne er fast ude på skolerne i ugens løb, hvilket medvirker til en kortere vej til sparring. Der holdes en tæt dialog mellem skoleforvaltningen og PPR, og PPRlederen er en del af skoleledergruppen.

Der er etableret økonomiske incitamenter for inklusion, og det overordnede princip er, at pengene følger eleven. Skolerne skal dog maksimalt betale 145.000 for en elev, der placeres i et specialtilbud.

Lærerne og pædagogerne er ansvarlige for det konkrete inklusionsarbejde, der skal foregå ude i den enkelte klasse. Til tider en vanskelig opgave, som personalet ikke kan overuddannes til, hvilket er et grundvilkår.

De personer og indsatser, der har haft størst positiv betydning for omstillingen, er de to videnscentre, der er etableret.

Der har ikke været nogen klager fra forældre til elever uden særlige behov, og der er utrolig lidt kritik fra forældre til inkluderede elever, hvad der opleves som et godt tegn.

Der er ingen kommunal strategi for brugen af supplerende undervisning og anden faglig støtte. Dette er den enkelte skoleleders ansvar, som udmøntes i samarbejde med skolens kompetencecenter. Det samme gælder for brugen af inklusionsfremmende indsatser. Man lægger i øvrigt vægt på, at skolerne skal trække på "hele paletten" af støttende og rådgivende instanser, der er etableret.

Ved starten af 2015 mærker man især, at skolereformen fylder. Der er årvågenhed om inklusion, men det er nu i gruppe med andre "store ting". Der satses på fortsat kompetenceudvikling, og man er i den forbindelse meget opmærksomme på, at kompetenceudvikling kommer til at stå på "flere ben". Det, der mangler, er vægt på praksisniveauet - hvad man konkret gør i en klasse for at sikre inklusion.

\section{PPR}

PPR har ligget i Skole- og kulturafdelingen siden strukturreformen i 2007. Alle PPRmedarbejdere har i forbindelse med omstillingen til inklusion modtaget efteruddannelse i konsultative metoder.

Kommunen iværksatte i august 2011 en række initiativer på skoleområdet, hvor der bl.a. blev beskrevet ændrede vilkår for PPR. Kommunen definerede, at PPR skulle arbejde mere konsultativt og ikke alene afklare problemstillinger. PPR skulle kunne være 
med til at etablere en konkret indsats og sætte mål for, hvordan og hvornår denne indsats skulle evalueres. Endvidere blev der opstillet nogle meget tydelige retningslinjer for og forventninger til, hvordan PPR skulle samarbejde med skoleledelserne, og hvordan det konsultative samarbejde med lærere og pædagoger skulle foregå. Det blev endvidere udspecificeret, hvornår elever med særlige behov skulle have foretaget en pædagogiskpsykologisk vurdering.

I visitationsprocessen er det skolens kompetenceråd, der i samarbejde med skolelederen indstiller til visitation. Kompetencerådet (hvor bl.a. psykolog og skoleledelse deltager) er et rådgivende organ for skolelederen, og der findes et sådant på alle kommunens skoler. Visitation til specialtilbud foretages én gang årligt. Elever kan under ganske særlige omstændigheder optages i specialtilbud i løbet af året. Skolelederne har fortsat ansvaret for visitationsprocessen. Før et barn indstilles til visitation til et andet skoletilbud, arbejdes der fokuseret i almenskolerne for at finde evt. alternative muligheder i almenområdet. Derudover arbejdes der løbende med nye handlemuligheder og tiltag i almenområdet i forhold til at kunne inkludere flere børn med forskellige behov.

Det opleves, at PPR-medarbejderne har fået en større berøringsflade og kendskab til flere børn i almenområdet, hvor vanskeligheder og udfordringer endnu ikke kræver en decideret indstilling. Det konsultative arbejde fylder mere, og PPR-medarbejderne arbejder med flere forebyggende sager. Det fornemmes, at PPR's brugere har fået en anden forståelse for, hvad PPR kan bidrage med og bruges til. Generelt opleves, at der i almenområdet arbejdes med større forståelse og accept af at forsøge at understøtte det enkelte barn i almenområdet med fokus på inklusion. PPR's nye konsultative rolle har ikke givet færre indstillinger, tværtimod er mængden af sager steget.

I arbejdet med børn, der er indstillet, og i forhold til det konsultative arbejde er samarbejdet med skoler, daginstitutioner og forældre omdrejningspunktet i udredning og igangsættelse af indsatser. Samarbejdet giver anledning til overvejelser over, hvordan samarbejdet mellem almenundervisningen og specialundervisningen kan udvikles yderligere, og hvordan forældre kan inddrages som aktive deltagere.

PPR arbejdede også med KL's pejlemærker i 2014. Det satte gang i en del diskussioner, og der blev iværksat forskellige projekter, bl.a. blev flere af PPR-medarbejderne inspireret til mere systematisk at notere, hvad deres tid blev brugt på, og der blev igangsat et supervisionsprojekt. PPR er i 2015 gået bort fra at arbejde med et ydelseskatalog, da der er sket og sker så mange ændringer på skolerne, at det på nuværende tidspunkt ikke giver mening.

I forhold til samarbejdet mellem skolerne og PPR beskrives det fortsat, at lærerne arbejder aktivt for at inkludere mange forskellige børn, men at det kan være svært at bevare fokus på inklusion. I indeværende skoleår har der på skoleområdet været mange 
nye tiltag, og det er derfor altafgørende, at der er en grundig forventningsafstemning personale og PPR imellem, for at indsatserne skal lykkes.

I forhold til det kommende år vil PPR have øget fokus på arbejdet med elever med sociale og emotionelle vanskeligheder, da denne elevgruppe fylder mere og mere hos lærerne og på skolerne. PPR vil endvidere gerne arbejde på et endnu tættere samarbejde med de enkelte skoler.

\section{Kommune $\mathrm{K}$}

\begin{tabular}{|l|l|}
\hline Kommunetype & Mellemstor landkommune \\
\hline Antal folkeskoler 2015 & 20 \\
\hline Antal frie skoler 2015 & 8 \\
\hline Andel af elever i frie skoler 2013 & 21,6 pct. \\
\hline Antal specialklasser 2013-2015 & $40-40-0$ \\
\hline Antal specialskoler 2013- 2015 & $6-6-3$ \\
\hline Socialøkonomisk indeks 2015 & 1,13 \\
\hline Nettodriftsudgifter pr. elev 2012-2014 & $78.089 \mathrm{kr} .-76.630 \mathrm{kr} .-76.987 \mathrm{kr}$. \\
\hline Ændring nettodriftsudgifter 2012-2013 & $-1,9$ pct. \\
Ændring nettodriftsudgifter 2013-2014 & 0,5 pct. \\
Ændring nettodriftsudgifter 2012-2014 & $-1,4$ pct. \\
\hline Udgift pr. elev i forhold til socialøkono- & -3.500 kr. \\
misk indeks & \\
\hline Inkluderet andel 2010 & 89,5 pct. \\
\hline Inkluderet andel 2013 -2015 & 91,3 pct. - 92,2 pct. - 93,7 pct. \\
\hline
\end{tabular}

\section{Skoleforvaltningen}

Man startede i 2010 med at ville analysere situationen på specialundervisningsområdet, herunder finde en måde, hvorpå man kunne omfordele midler. Det har imidlertid været en vanskelig proces at få i gang, først i 2012 lykkedes det. I foråret 2013 indledte kommunalbestyrelsen arbejdet med at etablere delmål for inklusionsprocessen i kommunen. Man arbejdede ud fra spørgsmålene: Hvilke børn kan vi få ud i almenområdet? Hvilke faglige kompetencer er nødvendige for at igangsætte processen? I 2014 begyndte man at kigge nøje på, hvilke elever der visiteredes, og man kan i 2015 mærke, at det har hjulpet på at øge inklusionen.

Med hensyn til kompetenceudvikling er hele kommunen, såvel skoler som daginstitutioner, med i LP-modellen, og man etablerede efteruddannelsesforløb, der startede august 2013. Forløbene var på forskellige niveauer. Der var et lederuddannelsesforløb samt et kursus for 100 lærere. Der var tale om kurser i klasseledelse, dialog og krav uden konflikt, som kommunen selv har udviklet. Man har helt specifikt ikke ønsket, at efter- 
uddannelser skulle være dele af diplomforløb. Endvidere har kommunen købt sig til procesguider og coaches fra en anden kommune og eksterne oplæg fra forskere. Endelig har kommunen entreret med James Nottingham og Challenging Learning om at gennemføre et forløb på nogle af kommunens skoler.

I 2014 har man nedlagt specialklasserækker og sammenlagt to specialskoler. Specialklasserækkerne er sammenlagt til tre inklusionscentre på tre skoler, hvor de skal have så tæt tilknytning til almenundervisningen som overhovedet muligt. Inklusionscentrene har en rolle som "inklusionsformidlere", der har et ansvar for de skoler, der ikke har inklusionscentre. I 2015 vil man have øget fokus på de elever, der er i eksterne tilbud, og se på hvilke strategier, der kan bruges for at rumme dem i egne tilbud, og det sker i et tværfagligt forvaltningssamarbejde. Politisk set har man ikke ønsket at forbinde inklusion med penge, og der er derfor lagt vægt på, at der ikke er tale om en spareøvelse. Det er derfor blevet afvist, at der skal gives direkte økonomiske incitamenter til inklusion til de enkelte skoler. Det skal opleves som en succes at beholde børnene i almenundervisningen. Dog nævnes det, at incitamenter kan komme på tale i 2016-17. Kommunens skoler tildeles ressourcer efter elevtal. Der indgår ikke en socioøkonomisk faktor. Det er op til de enkelte skoler, hvordan de anvender midler til supplerende undervisning, men der stilles krav om begrundelse, handleplan og dokumentation.

Der er sat måltal på, hvor mange elever der i skoleåret 2015/16 skal være i inklusionscentrene og på specialskolen, og kommunen er godt på vej mod disse mål. Der er lagt det princip, at de penge, der spares ved at nedlægge pladser i særtilbud, overføres til almenundervisningen. Det formelle ansvar for inklusionen ligger i fagcentrene for småbørn og undervisning samt hos skolelederne. Der er ikke lagt en kommunal ramme for brugen af ressourcer til supplerende undervisning og anden faglig støtte. Skolelederne kan anvende ressourcerne til "varme hænder" eller andet, de finder mest hensigtsmæssigt i de givne tilfælde. Når det gælder inklusionsfremmende initiativer holder man fra kommunens side et vist øje med, hvordan ressourcerne bliver brugt. Man har forsøgt at bruge personalet fra specialskolen som ressourcepersoner, men det har på grund af kulturforskelle været vanskeligt.

Kompetenceudvikling er sket ved, at 100 lærere har været på et 3-dages kursus i coaching, samtale og samarbejde, og der har også været fokus på egen faglighed. Kurset, der er blevet modtaget meget positivt, har lagt sig op ad LP-modellen, hvor alt pædagogisk personale har haft et kursusforløb. 24 ledere og medarbejdere har også været på et formaliseret kursus om inklusion.

Man har søgt at skabe ejerskab til inklusion blandt medarbejdere og forældre ved, at der er etableret et ad hoc-udvalg, der skal omsætte tankerne om inklusion til praksis, og der er afholdt møder med tillidsmænd og skoleledere. Skolebestyrelserne har en cen- 
tral rolle i forhold til forældrene, og der er afholdt fyraftensmøder, hvor forældre er indbudt, og hvor man har givet oplysninger om, hvad inklusion betyder, og hvordan forældre kan støtte op. Der har i slutningen af 2014 været et møde for skolebestyrelsesformændene, og de har her berettet, at de ikke ser problemer i forbindelse med inklusion. Der lægges stor vægt på elevernes trivsel, og den har en central placering i kommunens kvalitetsrapport. DCUM's termometer bruges hvert år på alle klassetrin; der er udarbejdet en handleguide, og man har også opnået bedre resultater.

\section{PPR}

PPR har siden 1. januar 2013 ligget under Børn- og ungeforvaltningen. Dette er gjort ud fra et ønske om at samle fagcentre i én forvaltningsenhed. I 2013 blev der ansat en ny leder, som arbejdede målrettet mod at få vendt synsfeltet fra klassisk diagnosticering mod en mere understøttende funktion med henblik på at højne refleksionerne i det pædagogiske felt.

Udfordringen var, at psykologerne var fastlåste i traditionelle mønstre, hvor der blev taget udgangspunkt i det enkelte barn. Der blev arbejdet på, at PPR skulle blive mere synlig på skolerne. Talepædagogerne arbejdede på at blive bedre til at koordinere indsatser ude i institutionerne frem for at målrette en indsats til det enkelte barn.

Det har traditionelt været sådan, at det er skolelederen, der indstiller til visitation. Der har manglet en proces, hvor der opstilles udviklingsplan og målsætninger for elever med særlige behov i almenmiljøet, fulgt af en evaluering af indsatser og evt. igangsættelse af nye indsatser, inden der foretages en indstilling til PPR om iværksættelse af en pædagogisk-psykologisk vurdering. Indstillinger skal endvidere afklares med PPR-lederen, inden de finder sted. Visitationsudvalget består af Lederen af PUC (pædagogisk udviklingscenter), PPR-lederen, centerchef for Børn og Familie, centerchef for Småbørn og undervisning, leder af Børn og Unge, teamleder for småbørn og Inklusionskonsulenten, der koordinerer skoletilbud.

I 2014 var PPR og nogle af kommunens skoler i gang med at arbejde med udviklingsplaner, hvor der blandt andet blev arbejdet med en fælles forståelse af inklusion.

Alle PPR-medarbejdere har været på et kursus om en specifik analysemodel (Carrs model). Alle sager til videre foranstaltning skal igennem denne analysemodel. Der afsættes tid til dette hver fredag i to timer. Medarbejderne skal kunne redegøre for, hvad man præcist har tænkt sig i forhold til de enkelte sager. Ingen sager visiteres til børnepsykiatrisk afdeling, før de har været gennemgået i medarbejdergruppen. Det er PPR-lederen, der har det afgørende ord i sagen.

Dette har medført en reduceret henvisningsgrad. Kommunen er faktisk et år forud for sin egen plan. Skolelederne er gået aktivt ind i sagen og henviser ikke så mange, lige- 
som PPR-lederen kræver mere af psykologerne og har strammet op på henvisningskriterierne.

Fra 1. januar 2014 blev familiebehandlere og kontaktpersoner en del af afdelingen "Forebyggelse og PPR". Tanken var, at der skulle arbejdes med fælles forståelse af arbejdsprocesser. Idéen var at styrke det tværfaglige samarbejde ved at udvikle et fælles sprog og analyseapparat i forhold til inklusion. Der var endvidere et ønske om, at skolerne skulle blive mere aktive i processen og blive bedre til at forstå, at inklusion handler om at gøre almenområdet bredere og ikke fokusere så meget på vanskeligheder.

PPR-lederen har et tæt samarbejde med skoleforvaltningen. Lederen har deltaget i alle arbejdsgruppemøder omkring lukningen af alle kommunens specialklasser i august 2014. PPR sparrer på tværs af områderne i forhold til at opnå et fælles udgangspunkt for inklusionsprocessen, de er dog ikke nået så langt i forhold til skolerne endnu. Det fremhæves dog, at nogle skoler er mere med end andre. Der er skoler, som er begyndt at blive optaget af, at psykologen kan være med til at kvalificere processen. PPR-medarbejderne forsøger at tilrettelægge processen, så den passer til den enkelte skole.

Kommunen blev inddelt i tre distrikter med ca. tre til fire skoler i hvert i 2014. PPRmedarbejdere og sagsbehandlere blev fordelt på distrikterne. De arbejdede ikke i team, men blev fordelt således, at kørsel kunne begrænses. På sigt er det intentionen, at alle skal arbejde i faste team med fælles ansvar for distriktet.

I forhold til forventninger til det kommende år er der fra PPR-lederens side fokus på det tværprofessionelle samarbejde både $\mathrm{i}$ forhold til sparring mellem PPRmedarbejderne, men også i forhold til sagsbehandlere, således at en tidlig indsats optimeres. Distriktsteam blev etableret i slutningen af 2014, og det er også et ønske at få disse til at fungere optimalt i 2015. Der vil fortsat blive arbejdet med en fælles forståelse af sager gennem en specifik analysemodel (Carrs analysemodel). 


\section{Kommune L}

\begin{tabular}{|l|l|}
\hline Kommunetype & Mellemstor landkommune \\
\hline Antal folkeskoler 2015 & 5 \\
\hline Antal frie skoler 2015 & 6 \\
\hline Andel af elever i frie skoler 2015 & 21,3 pct. \\
\hline Antal specialklasser 2013 & $0-0-0$ \\
\hline Antal specialskoler 2013 & $1-1-1$ \\
\hline Nettodriftsudgifter pr. elev 2012-2014 & $62.947 \mathrm{kr} .-59.852 \mathrm{kr} .-68.519 \mathrm{kr}$. \\
\hline Ændring nettodriftsudgifter 2012-2013 & $-4,9$ pct. \\
Ændring nettodriftsudgifter 2013-2014 & 14,5 pct. \\
Ændring nettodriftsudgifter 2012-2014 & 8,9 pct. \\
\hline Socialøkonomisk indeks 2015 & 1,14 \\
\hline Udgift pr. elev i forhold til socialøkono- & -2.500 kr. \\
misk indeks & \\
\hline Inkluderet andel 2010 & 94,9 pct. \\
\hline Inkluderet andel 2013-2015 & 98,3 pct. - 99,2 pct. - 98,2 pct. \\
\hline
\end{tabular}

\section{Skoleforvaltningen}

I 2008 iværksatte kommunen, at der blev arbejdet med LP-modellen på samtlige skoler. I 2011 konstaterede man, at 34 pct. af skolebudgettet gik til ekskluderende undervisning, og man vedtog en gennemgribende ændring, som faldt sammen med ændring i kommunens skolestruktur, hvor 13 skoler blev til fem.

Kommunens officielle definition af inklusion lyder: Inklusion er den dynamiske, vedvarende proces, hvori skolen øger mulighederne for tilstedeværelse, oplevelse af fællesskab, aktiv deltagelse og højt læringsmæssigt udbytte for alle elever. I denne proces tages der særligt hensyn til de elever, der er i farezonen for marginalisering, eksklusion og lavt fagligt udbytte.

Den nævnte gennemgribende ændring med hensyn til inklusion gennemførtes ved, at man nedlagde samtlige specialskoler og specialklasser i skoleåret 2012/13. I stedet oprettede man et kompetencecenter, hvor 40-50 elever havde deres skolegang. Centeret blev tilknyttet den lokale distriktsskole, så man opnåede, at der var en samlet skole for alle elever. Centeret har to dele, den ene del består af en tidligere intern skole fra et behandlingstilbud, den anden del af tidligere autismeklasser. For de øvrige ca. 175 elever gjaldt, at de blev inkluderet i almenskolen. En mindre gruppe elever med multiple handicap går på eksterne specialtilbud, og der er ingen planer om at tage disse elever hjem.

Den meget kontante omstilling til inklusion gav nogen turbulens, ikke mindst fordi den var sket samtidig med skolestrukturændringen, hvor ledelserne på skolerne også 
blev ændret. På trods af omfattende kompetenceudvikling viste en undersøgelse i 2014, at lærerne ikke følte sig klædt på til inklusionsopgaven, men det var samtidig karakteristisk, at når der spurgtes om, hvem lærerne søgte råd hos, så var det hos kolleger, der heller ikke følte sig klædt godt nok på, og ikke hos dem, der faktisk havde de understøttende funktioner. Der er derfor i samarbejde Undervisningsministeriets læringskonsulenter foretaget en styrkelse af uddannelsen, synligheden og indsatsen fra de personer, der har de understøttende funktioner, og der er dannet 15 "superteams", der bliver klædt på til at facilitere inklusionen.

Man kunne fra starten klart se, at der var en nedgang i antallet af elever, der ekskluderedes, og faldet sås især i de nye årgange. Kommunen nåede allerede i 2013 målet for 2015, så kvantitativt er man helt med, men nogle lærere sætter spørgsmålstegn ved elevernes udbytte. Det erkendes også, at der har været tale om en proces, hvor kulturskiftet har været meget stort. Der har været forældre, som har talt og skrevet dårligt om inklusion. For at øge forældresamarbejdet afholdes dialogmøder af en times varighed om året med forældre til inkluderede børn.

PPR's funktion er ændret i retning af vejledning og konsultation - om end det har været svært at ændre den traditionelle kultur, da næsten ingen af psykologerne havde en pædagogisk baggrund. Der er ansat en inklusionsvejleder på hver af de fem skoler. Inklusionsvejlederen skal iagttage og varetage inklusionsforløb. Endelig har man i kommunen ansat fem trivselscoaches, en ved hver af distriktsskolerne. Inklusion støttes også ved, at kommunen har skånet skolerne for de generelle besparelser, kommunen i øvrigt er blevet pålagt, og ved at kommunalbestyrelsen har eftergivet et gammelt merforbrug på knap 20 mio. kr.

Hvad økonomiske incitamenter angår, ligger alle ressourcer som hovedprincip nu hos skolelederne, både den del, der ligger under ni ugentlige timer, og den del, som ligger over ni ugentlige timer. Det er dog sådan, at hvis en elev visiteres til kompetencecenteret, skal skolen betale et takstbeløb på 300.000 kr. En central pulje dækker forskellen mellem takstbeløbet og den faktiske udgift, der er væsentligt højere.

Kommunen udnytter de nye regler om lærernes tjenestetid til at styrke samarbejdet mellem lærere og pædagoger. Det er også et mål, at personalet er så meget som muligt sammen med eleverne. Det erkendes, at der ligger et arbejde i at få skabt et tillidsforhold mellem ledere og lærere, og at der i lærernes opfattelse af arbejdstid ligger en udfordring.

Brugen af ressourcer til supplerende undervisning og anden faglige støtte til enkeltelever er skolelederens ansvar, men læringskonsulenterne har en funktion, hvor de yder støtte til beslutningerne, og eventuelt kan "råbe vagt i gevær". Skolelederne har også 
ansvaret for inklusionsindsatser, men der er den strategi, at man skal være bevidst om, hvad man gør, og at man skal være fleksibel.

Politisk har man vedtaget en strategi for implementering af folkeskolereformen i kommunen, der strækker sig over årene 2014-2017. Ved starten af 2015 føler man, at kommunen stadig er i implementeringsfasen, hvor der er behov for fortsat støtte med kompetenceudvikling metodisk, didaktisk og fagfagligt.

\section{PPR}

PPR har siden 2007 hørt under Børn- og familieforvaltningen og har haft en meget traditionel funktion, hvor meget af arbejdet er gået med at udarbejde pædagogiskpsykologiske vurderinger. Der var i 2013 en ændringsproces i gang, hvor det var tanken, at psykologerne skulle arbejde mere konsultativt, og PPR fik ny leder.

PPR var ikke medtænkt som en aktiv aktør i udviklingen af og arbejdet med øget inklusion. PPR-lederen mener, at skolelederne og lærerne i 2013 havde et meget traditionelt syn på PPR's arbejdsopgaver og derfor ikke i starten, efter PPR's omstillingsproces, benyttede de nye tilbud ret meget, men i stedet har trukket på de tre læringskonsulenter. Først i 2014-2015 begynder skolerne at anvende PPR.

Kommunen har valgt, at der ikke skal være et officielt visitationsudvalg eller afholdes visitationsmøder, da idealet er, at alle børn skal inkluderes på almenskolerne. I stedet afholdes der tre årlige evalueringsmøder, som erstatter de tidligere visitationsmøder. Det sidste evalueringsmøde afholdes i foråret og erstatter de tidligere revisitationsmøder, hvor det vurderes, om elever, der får mere end ni timers specialpædagogisk bistand, fortsat skal have denne støtte. Udfordringen for PPR ligger i, at der ikke findes et egentligt revisitationsskema, hvorfor skolerne gerne vil have udarbejdet pædagogiskpsykologiske vurderinger. PPR har derfor "udviklet" en kortere udgave af en pædagogisk-psykologisk vurdering, som minder om det tidligere revisitationsskema.

Ønsker en skoleleder et ekskluderende tilbud til en elev, skal PPR fortsat udarbejde en pædagogisk-psykologisk vurdering. Ansøgning om et ekskluderende tilbud skal kvalitetssikres i skoleafdelingen, men valget er reelt skolelederens.

Psykologerne tager i stigende grad den konsultative rolle på sig og arbejder mere direkte intervenerende. Der er fortsat en frustration over, at skolerne ikke bruger PPR nok. Der er udarbejdet en statusanalyse, hvori lærerne svarer, at de ikke synes, at de har tid til at benytte PPR.

PPR beskriver, at de oplever, at lærerne er handlingslammede ovenpå konflikten, og at de ikke henter hjælp fra PPR. Det er et ønske, at skoleledelserne skal gå mere aktivt ind i inddragelsen af PPR. PPR-lederen udtrykker, at det er svært at få lov til at støtte lærerne, da de især vælger at søge støtte fra andre lærere. Der er endvidere ikke tradition 
for at modtage supervision på skolerne. Den nye PPR-leder har deltaget i et skoleledermøde og opfordret til en ny form for samarbejde. Skolelederne beskrives også som en presset gruppe, der også har været ude for store forandringer og derfor har vanskeligt ved at engagere sig $\mathrm{i}$ inddragelsen af PPR.

Der bliver ikke foretaget væsentligt færre pædagogisk-psykologiske vurderinger, og der er hele tiden fokus på det enkelte barn. Der er et mindre fald i antallet af indstillinger til PPR. Der er udarbejdet en ny plan for personalets allokering til bestemte skoler. PPR-medarbejderne er tilknyttet skoledistrikterne og har kontor ude i områderne, således at de bliver mere synlige og tilgængelige. PPR-lederen oplever, at PPR er mere velsete og ansete i dagtilbuddene.

I forhold til det kommende år udtrykker PPR-lederen, at PPR skal blive dygtigere til konsultative forløb. Der vil endvidere fortsat blive arbejdet på at styrke samarbejdet mellem de enkelte skoleledere og PPR, da de er centrale aktører i forhold til at styrke PPR's rolle på skolerne. 


\section{Kvantitative resultater på baggrund af oplysninger fra skoleforvalt- ningerne og Danmarks Statistik}

\section{Antal skoler og elever}

I det følgende gives en oversigt over de forandringer, der er sket i kommunerne fra 2013 til 2015.

Tabel 1. Antal folkeskoler 2013-2015

\begin{tabular}{|l|l|l|}
\hline Endret antal folkeskoler & $\begin{array}{l}\text { 2013-2014 - Antal kommu- } \\
\text { ner }\end{array}$ & $\begin{array}{l}\text { 2014-2015 - Antal kom- } \\
\text { muner }\end{array}$ \\
\hline Flere folkeskoler & 0 & 0 \\
\hline Samme antal folkeskoler & 10 & 11 \\
\hline Færre folkeskoler & 2 & 1 \\
\hline
\end{tabular}

Kilde: Administrative oplysninger hentet i kommunerne senest januar 2015

Der er sket en beskeden ændring i skoleantallet fra 2013 til 2015, idet der i to kommuner er nedlagt $\mathrm{i}$ alt to skoler, og i en kommune er der sammenlagt folkeskoler - der er dog samme antal matrikler som tidligere.

Tabel 2. Antal frie skoler 2013-2015

\begin{tabular}{|l|l|l|}
\hline Ændret antal frie skoler & 2013-2014 - Antal kommuner & $\begin{array}{l}\text { 2014-2015 - Antal kom- } \\
\text { muner }\end{array}$ \\
\hline Flere frie skoler & 1 & 2 \\
\hline Samme antal frie skoler & 10 & 10 \\
\hline Færre frie skoler & 1 & 0 \\
\hline
\end{tabular}

Kilde: Administrative oplysninger hentet i kommunerne senest januar 2015

Antallet af frie skoler har også ændret sig lidt. Der er i hele perioden nedlagt en fri skole og oprettet tre nye frie skoler. Oprettelsen af de nye frie skoler hænger sammen med skolestrukturændringer i de pågældende kommuner. 
Tabel 3. Elevtal i folkeskoler 2013-2015

\begin{tabular}{|l|l|l|}
\hline Fndret elevtal i folkeskoler & $\begin{array}{l}\text { 2013-2014 - Antal kommu- } \\
\text { ner }\end{array}$ & $\begin{array}{l}\text { 2014-2015 - Antal kom- } \\
\text { muner }\end{array}$ \\
\hline Flere elever i folkeskoler & 4 & 4 \\
\hline $\begin{array}{l}\text { Samme antal elever i folke- } \\
\text { skoler }\end{array}$ & 1 & 0 \\
\hline Færre elever i folkeskoler & 7 & 8 \\
\hline
\end{tabular}

Kilde: Administrative oplysninger hentet i kommunerne senest januar 2015

Ud over et generelt fald i elevtallet som resultat af mindre fødselsårgange hænger ændringer primært sammen med oprettelse eller nedlæggelse af frie skoler.

Tabel 4. Elevtal i frie skoler 2013-2015

\begin{tabular}{|l|l|l|}
\hline Endret elevtal i frie skoler & 2013-2014 - Antal kommuner & $\begin{array}{l}\text { 2014-2015 - Antal kom- } \\
\text { muner }\end{array}$ \\
\hline Flere elever i frie skoler & 5 & 9 \\
\hline $\begin{array}{l}\text { Samme antal elever i frie } \\
\text { skoler }\end{array}$ & 0 & 0 \\
\hline Færre elever i frie skoler & 7 & 3 \\
\hline
\end{tabular}

Kilde: Administrative oplysninger hentet i kommunerne senest januar 2015

Fra 2013 til 2014 var der et fald på 0,6 pct. i det samlede elevtal på de frie skoler. Dette er afløst af en stigning på 5,6 pct. fra 2014 til 2015. Dette skyldes først og fremmest tilkomsten af en privatskole af en betydelig størrelse i én af de tolv kommuner.

\section{Antal specialklasser og specialskoler samt elevtal 2013-2015}

Tabel 5. ÆEndring i antal specialklasser 2013-2015

\begin{tabular}{|l|l|l|}
\hline Ændret antal specialklasser & $\begin{array}{l}\text { 2013-2014 - Antal kommu- } \\
\text { ner }\end{array}$ & $\begin{array}{l}\text { 2014-2015 - Antal kom- } \\
\text { muner }\end{array}$ \\
\hline Flere specialklasser & 1 & 3 \\
\hline Samme antal specialklasser & 5 & 3 \\
\hline Færre specialklasser & 6 & 6 \\
\hline
\end{tabular}

Kilde: Administrative oplysninger hentet i kommunerne senest januar 2015

Der er over hele perioden sket et betydeligt fald i antallet af specialklasser. I 2013 var der 282 specialklasser, og i 2014 var der 258. I 2015 er der sket en markant reduktion, og an- 
tallet er nu nede på 195, hvad der først og fremmest skyldes, at 40 specialklasser i en kommune er sammenlagt til tre inklusionscentre på tre skoler, hvor de skal have så tæt tilknytning til almenundervisningen som overhovedet muligt.

Tabel 6. Ændring i antal specialskoler 2013-2015

\begin{tabular}{|l|l|l|}
\hline Ændret antal specialskoler & $\begin{array}{l}\text { 2013-2014 - Antal kommu- } \\
\text { ner }\end{array}$ & $\begin{array}{l}\text { 2014-2015 - Antal kom- } \\
\text { muner }\end{array}$ \\
\hline Flere specialskoler & 0 & 0 \\
\hline Samme antal specialskoler & 12 & 9 \\
\hline Færre specialskoler & 0 & 3 \\
\hline
\end{tabular}

Kilde: Administrative oplysninger hentet i kommunerne senest januar 2015

Mens der frem til 2014 ikke var sket nogen ændring i antallet af specialskoler i de 12 kommuner, er der fra 2014 til 2015 sket en reduktion på i alt fem specialskoler i tre kommuner.

Tabel 7. Ændring i antal elever i specialklasser 2013-2015

\begin{tabular}{|l|l|l|}
\hline $\begin{array}{l}\text { Endret elevtal i specialklas- } \\
\text { ser }\end{array}$ & $\begin{array}{l}\text { 2013-2014 - Antal kommu- } \\
\text { ner }\end{array}$ & $\begin{array}{l}\text { 2014-2015 - Antal kom- } \\
\text { muner }\end{array}$ \\
\hline Flere elever i specialklasser & 2 & 3 \\
\hline $\begin{array}{l}\text { Samme antal elever i special- } \\
\text { klasser }\end{array}$ & 1 & 1 \\
\hline Færre elever i specialklasser & 9 & 8 \\
\hline
\end{tabular}

Kilde: Administrative oplysninger hentet i kommunerne senest januar 2015

I såvel 2014 som 2015 er der i to tredjedele af kommunerne sket et fald i antallet af elever i specialklasser. Det samlede elevtal i specialklasser er faldet med 10,0 og 8,4 pct. pct. i henholdsvis 2014 og 2015.

Tabel 8. Ændring i elevtal i specialklasser uden for kommunen 2013-2015

\begin{tabular}{|l|l|l|}
\hline $\begin{array}{l}\text { Endret elevtal i specialklas- } \\
\text { ser uden for kommunen }\end{array}$ & $\begin{array}{l}\text { 2013-2014 - Antal kommu- } \\
\text { ner }\end{array}$ & $\begin{array}{l}\text { 2014-2015 - Antal kom- } \\
\text { muner }\end{array}$ \\
\hline Flere elever i specialklasser & 4 & 3 \\
\hline $\begin{array}{l}\text { Samme antal elever i special- } \\
\text { klasser }\end{array}$ & 4 & 4 \\
\hline Færre elever i specialklasser & 4 & 5 \\
\hline
\end{tabular}

Kilde: Administrative oplysninger hentet i kommunerne senest januar 2015 
Ænndringerne i kommunerne vist i tabel 8 dækker over, at der i 2014 skete et fald i antallet af elever i specialklasser uden for kommunen på 8,6 pct., et fald, der i 2015 er 12,5 pct.

Tabel 9. Ændring i elevtal i specialklasser bosiddende uden for kommunen 2013-2015

\begin{tabular}{|l|l|l|}
\hline $\begin{array}{l}\text { Ændret elevtal i specialklas- } \\
\text { ser fra andre kommuner }\end{array}$ & $\begin{array}{l}\text { 2013-2014 - Antal kommu- } \\
\text { ner }\end{array}$ & $\begin{array}{l}\text { 2014-2015 - Antal kom- } \\
\text { muner }\end{array}$ \\
\hline Flere elever i specialklasser & 5 & 4 \\
\hline $\begin{array}{l}\text { Samme antal elever i special- } \\
\text { klasser }\end{array}$ & 4 & 3 \\
\hline Færre elever i specialklasser & 3 & 5 \\
\hline
\end{tabular}

Kilde: Administrative oplysninger hentet i kommunerne senest januar 2015

Der er en betydelig variation kommunerne imellem med hensyn til ændret antal specialklasseelever bosiddende uden for kommunen. Totalt set er der dog tale om fald over begge år. I 2014 reduceredes elevtallet med 0,8 pct. og i 2015 med 9,1 pct.

Tabel 10. ÆEndring i elevtal i specialskoler 2013-2015

\begin{tabular}{|l|l|l|}
\hline Endret elevtal i specialskoler & $\begin{array}{l}\text { 2013-2014 - Antal kommu- } \\
\text { ner }\end{array}$ & $\begin{array}{l}\text { 2014-2015 - Antal kom- } \\
\text { muner }\end{array}$ \\
\hline Flere elever i specialskoler & 1 & 4 \\
\hline $\begin{array}{l}\text { Samme antal elever i special- } \\
\text { skoler }\end{array}$ & 4 & 5 \\
\hline Færre elever i specialskoler & 7 & 3 \\
\hline
\end{tabular}

Kilde: Administrative oplysninger hentet i kommunerne senest januar 2015

Også hvad antal elever i specialklasser angår, er der variation kommunerne imellem. Samlet set er der tale om et fald i elevtallet. Faldet er på 8,5 pct. i 2014 og på 7,6 pct. i 2015.

Tabel 11. Ændring i elevtal i specialskoler uden for kommunen 2013-2015

\begin{tabular}{|l|l|l|}
\hline $\begin{array}{l}\text { Ændret elevtal i specialskoler } \\
\text { uden for kommunen }\end{array}$ & $\begin{array}{l}\text { 2013-2014 - Antal kommu- } \\
\text { ner }\end{array}$ & $\begin{array}{l}\text { 2014-2015 - Antal kom- } \\
\text { muner }\end{array}$ \\
\hline Flere elever i specialskoler & 4 & 2 \\
\hline $\begin{array}{l}\text { Samme antal elever i special- } \\
\text { skoler }\end{array}$ & 3 & 2 \\
\hline Færre elever i specialskoler & 5 & 8 \\
\hline
\end{tabular}

Kilde: Administrative oplysninger hentet i kommunerne senest januar 2015 
Mens der i 2014 er en variation med hensyn til, om kommunerne har øget eller faldende børnetal i specialskoler beliggende uden for kommunen, er der i 2015 en generel reduktion. I 2014 var der en stigning på 2,1 pct., og den er afløst af et fald på 6,9 pct. i 2015.

Tabel 12. Ændring i elevtal bosiddende uden for kommunen i specialskoler 2013-2015

\begin{tabular}{|l|l|l|}
\hline $\begin{array}{l}\text { Endret elevtal i specialskoler } \\
\text { fra andre kommuner }\end{array}$ & $\begin{array}{l}\text { 2013-2014 - Antal kommu- } \\
\text { ner }\end{array}$ & $\begin{array}{l}\text { 2014-2015 - Antal kom- } \\
\text { muner }\end{array}$ \\
\hline Flere elever i specialskoler & 2 & 5 \\
\hline $\begin{array}{l}\text { Samme antal elever i special- } \\
\text { skoler }\end{array}$ & 6 & 3 \\
\hline Færre elever i specialskoler & 4 & 4 \\
\hline
\end{tabular}

Kilde: Administrative oplysninger hentet i kommunerne senest januar 2015

Der er betydelig variation i, om der er ændringer i antallet af specialskoleelever bosiddende i andre kommuner. Samlet set er der fra 2013 til 2014 tale om en øgning på 0,75 pct. i antal af elever med bopæl i andre kommuner. Fra 2014 til 2015 er der et fald på 9,2 pct.

\section{Inklusion}

Følgende tabeller viser inklusionsprocenter og ændringer i disse i årene 2010, 2013, 2014 og 2015. 
Tabel 13. Inklusionsprocenter 2010, 2013, 2014 og 2015

\begin{tabular}{|l|l|l|l|l|}
\hline Kommune & 2010 & 2013 & 2014 & 2015 \\
\hline A & 94,2 & 94,4 & 95,1 & 97,7 \\
\hline B & 96,1 & 97,0 & 97,4 & 97,7 \\
\hline C & 89,7 & 91,4 & 92,3 & 92,5 \\
\hline D & 92,5 & 93,2 & 94,1 & 95,2 \\
\hline E & 92,0 & 94,3 & 95,6 & 96,5 \\
\hline F & 97,5 & 97,8 & 97,6 & 97,5 \\
\hline G & 94,9 & 95,9 & 96,4 & 96,8 \\
\hline H & 92,3 & 94,3 & 94,3 & 96,8 \\
\hline I & 91,8 & 96,3 & 96,0 & 95,8 \\
\hline J & 91,7 & 94,5 & 95,4 & 95,2 \\
\hline K & 89,5 & 91,3 & 92,2 & 93,7 \\
\hline L & 94,9 & 98,3 & 99,2 & 98,2 \\
\hline Gennemsnit & 93,1 & 94,9 & 95,5 & 96,0 \\
\hline
\end{tabular}

Kilde: Administrative oplysninger hentet i kommunerne senest januar 2015

Tabellen, hvor kommunernes bogstavangivelse rummer mulighed for at sammenkoble med kommuneportrætterne, giver et klart billede af, at inklusionen er øget. I de 12 kommuner lå gennemsnittet i 2010 2,9 procentpoint under målsætningen for 2015. I 2013 lå det 1,1 procentpoint fra målet, I 2014 var gennemsnittet 0,5 procentpoint fra målet. I 2015 er målet nået. Der er dog betydelige forskelle kommunerne imellem. Mens der i 2010 var to kommuner, der havde nået målet, gjaldt det i 2013 fire kommuner, i 2014 fem kommuner og i 2015 otte kommuner. 
Tabel 14. Ændring i inklusionsprocenter årene 2013, 2014 og 2015

\begin{tabular}{|l|l|l|l|}
\hline Kommune & 2013 & 2014 & 2015 \\
\hline A & $-0,2$ & $+0,6$ & $+2,6$ \\
\hline B & $+0,9$ & $+0,4$ & $+0,3$ \\
\hline C & $+1,7$ & $+0,9$ & $+0,2$ \\
\hline D & $+0,7$ & $+0,9$ & $+1,1$ \\
\hline E & $+2,3$ & $+1,4$ & $+0,9$ \\
\hline F & $+0,3$ & $-0,2$ & $-0,1$ \\
\hline G & $+1,0$ & $+0,5$ & $+0,4$ \\
\hline H & $+2,0$ & 0,0 & $+2,5$ \\
\hline I & $+4,5$ & $-0,3$ & $-0,2$ \\
\hline J & $+2,8$ & $+0,9$ & $-0,2$ \\
\hline K & $+1,8$ & $+0,8$ & $+1,5$ \\
\hline L & $+3,4$ & $+0,8$ & $-1,0$ \\
\hline
\end{tabular}

Kilde: Administrative oplysninger hentet i kommunerne senest januar 2015

Tabellen illustrerer hvor stor en ændring i procentpoint, der er sket i inklusionsprocenterne i de tolv kommuner over de tre år, undersøgelsen dækker. Hvis man ser på ændringerne, gælder, at maksimum i 2013 var 4,5 procentpoint, mens en enkelt kommune havde mindsket inklusionen med -0,2 procentpoint. I 2014 er den største positive ændring på 1,4 procentpoint, mens den største ændring i negativ retning er -0,3 procentpoint. I 2015 er den største positive ændring 2,6 procentpoint og det største fald -1,0 procentpoint. Otte kommuner har øget inklusionen, mens fire kommuner har mindsket den.

\section{Budgetforhold}

I dette afsnit gives en række oplysninger om de økonomiske forhold i de tolv kommuner. Afsnittet starter med budgetmæssige forhold, der siger noget om kommunernes prioriteringer af områder. Oplysninger om de budgetmæssige forhold er afgivet af de kommunale forvaltninger i forbindelse med de tre dataindsamlingsrunder. Det efterfølgende afsnit bringer en oversigt over regnskabsførte nettodriftsudgifter, hvor oplysningerne stammer fra Danmarks Statistik. 
Tabel 15. Samlet budget for elever med særlige behov 2013-2015

\begin{tabular}{|l|l|l|}
\hline ÆEndret budget & $\begin{array}{l}\text { 2013-2014 - Antal kommu- } \\
\text { ner }\end{array}$ & $\begin{array}{l}\text { 2014-2015 - Antal kom- } \\
\text { muner }\end{array}$ \\
\hline Større budget & 8 & 0 \\
\hline Samme budget & 0 & 1 \\
\hline Mindre budget & 3 & 0 \\
\hline $\begin{array}{l}\text { Kan ikke opgøres pga. bud- } \\
\text { getændring }\end{array}$ & 1 & 11 \\
\hline
\end{tabular}

Kilde: Administrative oplysninger hentet i kommunerne senest januar 2015

Allerede i 2014 viste det sig, at de 12 kommuner efterhånden havde en meget forskellig budgettering for indsatsen for elever med særlige behov, som gives i almenklasser. Nogle kommuner havde stadig budgetter for specialundervisning (over ni klokketimer om ugen), for supplerende undervisning og anden faglig støtte og for inklusionsfremmende initiativer. Tendensen gik imidlertid i retning af, at der er et samlet budget for de tre poster, og at det derefter er op til skolernes ledelser at udmønte det.

I 2015 er ændringen slået næsten fuldstændigt igennem. Syv kommuner har et budget for specialundervisning, tre kommuner har et budget for supplerende undervisning og anden faglig støtte, seks kommuner har et budget for inklusionsfremmende initiativer, og kun en kommune har budgetter for alle tre områder. Der er derfor kun en kommune, hvor man kan sammenligne 2014 og 2015, og her er der tale om samme beløb.

Det mest almindelige er nu, at skolerne har en basisbevilling tildelt efter forskellige kriterier i de forskellige kommuner, og det er derefter op til skoleledelsen at fordele midlerne til forskellige formål. Der eksisterer dog i flere kommuner forskellige former for centrale puljer, der kan udløses i særligt påkrævede tilfælde, især til mindre skoler. Det er derfor ikke længere muligt at sige noget sikkert om, i hvilken grad elever med særlige behov udløser ekstra ressourcer på skolerne, og hvilke principper der anvendes ved ressourceallokering.

Tabel 16. AEndringer i budget til kompetenceudvikling i inklusion 2013-2015

\begin{tabular}{|l|l|l|}
\hline ÆEndret budget & $2013-2014-$ Antal kommuner & $\begin{array}{l}\text { 2014-2015 - Antal kom- } \\
\text { muner }\end{array}$ \\
\hline Større budget & 4 & 2 \\
\hline Samme budget & 2 & 0 \\
\hline Mindre budget & 5 & 6 \\
\hline Kan ikke opgøres & 1 & 4 \\
\hline
\end{tabular}

Kilde: Administrative oplysninger hentet i kommunerne senest januar 2015 
Mens alle tolv kommuner i 2013 havde et separat budget for kompetenceudvikling med henblik på inklusion, var der i 2014 én kommune, der ikke kunne angive et separat budget for inklusion, da man opererede med et samlet beløb til al kompetenceudvikling. I 2015 er billedet det, at der nu er fire kommuner, hvor man ikke kan angive et beløb til kompetenceudvikling i inklusion, idet det $\mathrm{i}$ de tre af kommunerne indgår i generel kompetenceudvikling, bl.a. i forbindelse med skolereformen, og i en kommune er al kompetenceudvikling udlagt til de enkelte skolers ledelse. I 2014 var det største fald i budgetter på 65 pct., og det lå i en kommune, hvor der var oprettet to videnscentre, som kompetenceudviklede ved at indgå i skolernes praksis. I 2015 har to kommuner øget budgetterne for kompetenceudvikling med henblik på inklusion, da man har skønnet, der var et større behov. I den ene kommune er stigningen på 15 pct., i den anden er den på 45 pct. Seks kommuner har mindsket budgettet, og det hænger sammen med, at beløbene er konverteret til ansættelse af vejledere og konsulenter, der bistår med kompetenceudvikling i den daglige praksis.

Hvis man udregner budgettet for kompetenceudvikling i inklusion pr. elev, opnås et mere nuanceret billede. Budgettet til kompetenceudvikling i inklusion lå i 2013 mellem 105 kr. og 1.111 kr. med et gennemsnit på 381 kr. For 2014 ligger budgetterne mellem 119 kr. og 1.092 kr. med et gennemsnit på 481 kr. Det skal dog bemærkes, at en enkelt kommune lægger alle midler ud til skolerne, hvorfor det ikke med sikkerhed kan siges, hvilke formål de bruges til. I 2015 er antallet af kommuner, hvor forbruget til inklusion ikke kan angives specifikt, øget til fire. Gennemsnittet pr. elev i de resterende kommuner er 272 kr. pr. elev med en spændvidde fra 81 kr. til 702 kr. pr. elev. Følgende tabel, hvor kommunerne er anonyme, viser beløbene pr. elev for de tre år. 
Tabel 17. Budget pr. elev i kr. til kompetenceudvikling i inklusion i 2013, 2014 og 2015

\begin{tabular}{|l|l|l|}
\hline Budget pr. elev i kr. 2013 & Budget pr. elev i kr. 2014 & Budget pr. elev i kr. 2015 \\
\hline 284 & 224 & 207 \\
\hline 467 & 253 & 702 \\
\hline 360 & 357 & - \\
\hline 334 & 119 & 81 \\
\hline 105 & - & - \\
\hline 1111 & 1092 & 198 \\
\hline 386 & 386 & - \\
\hline 273 & 272 & 256 \\
\hline 579 & 372 & 288 \\
\hline 322 & 459 & 590 \\
\hline 200 & 864 & 111 \\
\hline 150 & 383 & - \\
\hline
\end{tabular}

Kilde: Administrative oplysninger hentet i kommunerne senest januar 2015

Det fremgår af tabellen, at der er meget varierende budgetter til kompetenceudvikling i de tolv kommuner, og at der i flere tilfælde også er en variation i den enkelte kommune over de tre år. Det højeste niveau overhovedet ligger på 1.111 kr. pr. elev, det laveste på 81 kr. pr. elev. I 2014 er der en kommune, hvor man ikke kan oplyse om budget, fordi alt er lagt ud til de enkelte skoler. I 2015 er antallet, hvor dette sker, forøget til tre.

Tabel 18. Ændringer i budget til PPR 2013-2015

\begin{tabular}{|l|l|l|}
\hline Ændret budget & 2013-2014 - Antal kommuner & $\begin{array}{l}\text { 2014-2015 - Antal kom- } \\
\text { muner }\end{array}$ \\
\hline Større budget & 3 & 3 \\
\hline Samme budget & 2 & 1 \\
\hline Mindre budget & 7 & 5 \\
\hline Kan ikke afgøres & 0 & 3 \\
\hline
\end{tabular}

Kilde: Administrative oplysninger hentet i kommunerne senest januar 2015

I 2014 udgjorde den største stigning i budget til PPR 15 pct., og den lå i en kommune, hvor man mest udtalt havde tildelt PPR nye roller i inklusionsprocessen. Næststørste stigning var på 1 pct. Det største fald var på 51 pct., og det var i en kommune, hvor man havde restruktureret PPR meget betydeligt. Næststørste fald var på 46 pct. i en kommune, hvor man også havde foretaget en større omorganisering af PPR. Når man sammenligner budgetter til PPR for årene 2014 og 2015, er der også forskydninger. Tre har fået flere ressourcer, en har samme budget, og fem har lavere budgetter. Der er imidlertid - 
med en enkelt undtagelse som følge af omstruktureringer - tale om meget marginale forskydninger.

Hvis man udregner budget til PPR pr. elev lå de i 2013 på et gennemsnit på 2.119 kr. med et maksimum på 3.234 kr. og et minimum på 929 kr. I 2014 var gennemsnittet 1.968 kr., maksimum 3.359 kr., minimum 929 kr. I 2015 er gennemsnittet 2.145 kr., maksimum 3.442 kr., minimum $1.492 \mathrm{kr}$.

Tabel 19. Ændringer i samlede budgetter til folkeskolen pr. elev 2014-2015

\begin{tabular}{|l|l|l|}
\hline Ændret budget pr. elev & 2013-2014 - Antal kommuner & $\begin{array}{l}\text { 2014-2015 - Antal kom- } \\
\text { muner }\end{array}$ \\
\hline Større budget & 5 & 6 \\
\hline Samme budget & 1 & 1 \\
\hline Mindre budget & 6 & 5 \\
\hline
\end{tabular}

Kilde: Administrative oplysninger hentet i kommunerne senest januar 2015

Mens der i 2014 var fem kommuner, der havde et større samlet budget for folkeskolen end året før, en kommune, der havde samme budget, og seks kommuner, der havde et lavere budget, er situationen i 2015 den, at seks kommuner har et højere budget, en har samme budget, og fem har et lavere budget. Fra 2013 til 2014 faldt budgetterne med 4,93 pct., mens de fra 2014 til 2015 steg 4,87 pct. Alt i alt betyder dette, at der fra 2013 til 2015 er en gennemsnitlig nedgang i det samlede budget på 0,30 pct., mens elevtallet i de tolv kommuner i samme tidsrum er faldet 0,27 pct., hvorved der er sket en marginal ændring på 0,02 pct.

Undervisningsministeriet har til brug for denne rapport beregnet udviklingen i budgetterede nettodriftsudgifter til folkeskolen for perioden 2012 til 2015. Frem til og med skoleåret 2013/2014 er beregningerne baseret på det seneste eksakt opgjorte elevtal, mens elevtallene for 2014 er delvis og for 2015 fuldt ud prognosebaserede. Ved denne fremgangsmåde udgør tallene for 2012, 2013, 2014 og 2015 henholdsvis 69.289, 69.596, 69.522 og 72.054. Ændringen i budgetterede nettodriftsudgifter udgør for 2012-2013, 2013-2014 og 2014-2015 henholdsvis $+0,4$ pct., $-0,1$ pct. og $+3,6$ pct. Samlet ændring fra 2012 til 2015 udgør $+4,0$ pct. Udviklingen i de samlede budgettal viser stort set uændret udgiftsniveau fra 2012 til 2014 og derefter en betydelig stigning fra 2014 til 2015 svarende til, at folkeskolereformen først er fuldt implementeret i 2015.

\section{Regnskabsførte nettodriftsudgifter (fra Danmarks Statistik)}

Mens budgetterne siger noget om kommunernes prioriteringer, giver de regnskabsførte nettodriftsudgifter et mere sikkert billede af, hvordan pengene bliver brugt. I de følgen- 
de tabeller vil der blive fokuseret på udgifterne pr. elev i de 12 kommuner. Man skal i den forbindelse være opmærksom på, at udgifterne pr. elev er påvirket af demografiske forhold, herunder først og fremmest socioøkonomiske forhold og skolestruktur. Hvad det første angår, vil en lav gennemsnitlig socioøkonomisk baggrund betyde, at der er behov for flere ressourcer pr. elev for at opnå samme kvalitet. Hvad det andet angår, vil en kommune med mange små skoler have sværere ved at optimere klassestørrelsen og dermed opnå en økonomisk rationel drift. Socioøkonomisk baggrund er angivet som et indeks i kommuneportrætterne, hvor det også er sat i relation til udgifterne pr. elev. De regnskabsførte nettodriftsudgifter er beregnet på bagrund af data fra Danmarks Statistik. Alle data er fra Danmarks Statistik, statistikbanken.dk, tabel REGK31 (udgifter) og tabel UDDAKT22 (elevtal). Udgifterne omfatter de regnskabsførte nettodriftsudgifter inkl. statsrefusioner og ekskl. tjenestemandspensioner for følgende funktioner i det kommunale budget- og regnskabssystem: 3.22.01. Folkeskoler, 3.22.07. Specialundervisning i regionale tilbud, 3.22.08. Kommunale specialskoler og fra regnskab 2014 tillige den nyoprettede funktion 3.22.09. Efter- og videreuddannelse i folkeskolen. Elevtallene omfatter elever i almindelige folkeskoler, inkl. specialklasser, elever i specialskoler herunder regionale tilbud, samt elever i dagbehandlingstilbud og på anbringelsessteder. Elevtallene er omregnet fra skoleår (september det pågældende år) til kalenderår, således at 7/12 af det afsluttende skoleår og 5/12 af det påbegyndte skoleår indgår i kalenderårets elevtal. I elevtal for "Hele landet" indgår elever på Christiansø og elever med uoplyst kommune. De samlede elevtal for de pågældende år afviger marginalt fra Undervisningsministeriets elevtal. 
Tabel 20. Regnskabsførte nettodriftsudgifter pr. elev (2016-prisniveau)

\begin{tabular}{|l|l|l|l|}
\hline Kommune/årstal & 2012 & 2013 & 2014 \\
\hline A & 69.332 & 66.615 & 68.646 \\
\hline B & 68.799 & 67.123 & 70.671 \\
\hline C & 85.573 & 84.997 & 87.887 \\
\hline D & 67.252 & 66.673 & 71.601 \\
\hline E & 69.250 & 69.929 & 73.390 \\
\hline F & 63.505 & 61.965 & 70.222 \\
\hline G & 64.893 & 60.644 & 62.701 \\
\hline H & 81.049 & 78.558 & 83.315 \\
\hline I & 74.525 & 71.326 & 77.061 \\
\hline J & 72.500 & 67.255 & 69.222 \\
\hline K & 78.089 & 76.630 & 76.987 \\
\hline L & 62.947 & 59.852 & 68.519 \\
\hline Alle 12 kommuner & 69.932 & 67.359 & 70.936 \\
\hline Hele landet & 69.249 & 67.687 & 71.498 \\
\hline
\end{tabular}

Kilde: Danmarks Statistik

Tabel 21. Endring i regnskabsførte nettodriftsudgifter pr. elev

\begin{tabular}{|l|l|l|l|}
\hline $\begin{array}{l}\text { Kommune/ændring i } \\
\text { pct. }\end{array}$ & $2012-2013$ & $2013-2014$ & $2012-2014$ \\
\hline A & $-3,9$ & $+3,0$ & $-1,0$ \\
\hline B & $-2,4$ & $+5,3$ & $+2,7$ \\
\hline C & $-0,7$ & $+3,4$ & $+2,7$ \\
\hline D & $-0,9$ & $+7,4$ & $+6,5$ \\
\hline E & $+1,0$ & $+4,9$ & $+6,0$ \\
\hline F & $-2,4$ & $+13,3$ & $+10,6$ \\
\hline G & $-6,5$ & $+3,4$ & $-3,4$ \\
\hline H & $-3,1$ & $+5,9$ & $+2,7$ \\
\hline I & $-4,3$ & $+8,0$ & $-3,4$ \\
\hline J & $-7,2$ & $+2,9$ & 4,5 \\
\hline K & $-1,9$ & $+0,5$ & $-1,4$ \\
\hline L & $-4,9$ & $+14,5$ & $+8,9$ \\
\hline Alle 12 kommuner & $-3,7$ & $+5,3$ & $+1,4$ \\
\hline Hele landet & $-2,3$ & $+5,6$ & $+3,2$ \\
\hline
\end{tabular}

Kilde: Danmarks Statistik

De to tabeller peger på, at de samlede regnskabsførte udgifter falder fra 2012 til 2013, hvilket i høj grad må antages at hænge sammen med overenskomstkonflikten i april 
2013. Undervisningsministeriet skønner, at det samlede regnskabstal for 2013 er reduceret med mere end 1 mia. kr. som følge af konflikten. Fra 2013 til 2014 er udgiftsniveauet forøget, så det overstiger niveauet for 2012, hvad der formentlig hænger sammen med implementeringen af folkeskolereformen fra august 2014.

Hvis man stiller ændringer i regnskabsførte nettodriftsudgifter over for ændringer i inklusionsprocenten i de 12 kommuner, fås billedet vist i følgende tabel.

Tabel 22. Ændringer i regnskabsførte nettodriftsudgifter pr. elev i pct. og i inklusionsprocenter

\begin{tabular}{|l|l|l|}
\hline Kommune & $\begin{array}{l}\text { Ændring i nettodriftsudgif- } \\
\text { ter } \\
2012-2014\end{array}$ & $\begin{array}{l}\text { Ændring i inklusionspro- } \\
\text { cent } \\
2012-2015\end{array}$ \\
\hline A & $-1,0$ & 3,0 \\
\hline B & $-2,7$ & 1,6 \\
\hline C & $+2,7$ & 2,8 \\
\hline D & $+6,5$ & 2,7 \\
\hline E & $+6,0$ & 4,6 \\
\hline F & $+10,6$ & 0,0 \\
\hline G & $-3,4$ & 1,9 \\
\hline H & $+2,7$ & 4,5 \\
\hline I & $+3,4$ & 4,0 \\
\hline J & $-4,5$ & 3,5 \\
\hline K & $-1,4$ & 4,1 \\
\hline L & $+8,8$ & 2,2 \\
\hline
\end{tabular}

Kilde: Danmarks Statistik og administrative oplysninger indsamlet i kommunerne senest 2015

Tabellen viser, at der ikke kan findes entydige sammenhænge mellem ændringer i nettodriftsudgifter pr. elev og ændring i inklusionsprocent. Således er der i kommunen med den største stigning i udgiftsniveauet ikke sket nogen ændring i inklusionsprocenten, mens der i kommunen med den største negative ændring er tale om en betydelig stigning i inklusionsprocenten. I de syv kommuner med positiv udvikling i nettodriftsudgifter er den gennemsnitlige stigning i inklusion 2,97 procentpoint, mens den i de fem kommuner med negativ udvikling er 2,82 procentpoint. Man må derfor konstatere, at der er så mange faktorer, der spiller ind på kommunernes evne til at inkludere, at de overskygger indflydelsen fra nettodriftsudgifterne pr. elev. Blandt disse faktorer kan nævnes, at kommunerne ligger over eller under den udgift, der kan forventes i forhold til det socialøkonomiske indeks, og den inklusionsprocent kommunen havde før 2012 - 
igen set i forhold til socialøkonomisk indeks, og at kommunen forud for 2012 har investeret i kompetenceudvikling, fx brug af LP-modellen, uddannelse af et vejlederkorps eller etablering af samarbejde med specialklasser og specialskoler. Kommuneportrætterne illustrerer hvor stor forskellighed, der er kommunerne imellem, og sammenhænge vil blive søgt afdækket i de kvantitative analyser af relationerne mellem fokuspunkter og inklusionsindikatorer i del 2 samt i de kvalitative analyser i slutningen af del 1.

\section{Opsummering om skoleforvaltninger og PPR}

\section{Skoleforvaltninger}

I 2015 arbejder kommunerne fortsat med inklusion, og som gennemsnit har de nået målet om en inklusionsprocent på 96. Kommunerne har etableret målsætninger, der er udarbejdet strategier, som er i gang med at blive implementeret. Der har været tale om en ganske krævende udviklingsproces, hvor inklusion er gået fra et overordnet ideal til gradvist at blive en del af praksis.

De kommuner, der har været tidligst i gang, har også iværksat forudgående kompetenceudviklingsprogrammer for medarbejderne, før inklusionen er sat i gang rent organisatorisk. I de kommuner, der er gået i gang senere, er kompetenceudvikling og organisatoriske ændringer nærmest gået hånd i hånd. Der er ingen kommuner, som ikke har søgt at give personalet et kompetenceløft, og der har været afsat betydelige økonomiske ressourcer hertil. Der er også uddannet en lang række vejledere, som skal støtte lærere og pædagoger.

Det gælder for alle kommuner, at man har ladet ressourcer følge med over i den almene undervisning. Nogle steder har man ligefrem relativt set - i forhold til de øvrige budgetter i kommunen - tilført ressourcer til inklusionsprocessen. Der er fra 2012 til 2014 sket en øgning af nettodriftsudgifterne pr. elev på gennemsnitligt 1,4 pct., men med betydelig variation fra kommune til kommune.

I ti ud af de tolv kommuner er der etableret økonomiske incitamenter for inklusion, og der er hen over undersøgelsesperioden også gennemført en decentralisering af ansvaret for brugen af skolernes ressourcer, således at det i 2015 i alle kommuner er skoleledernes ansvar at udmønte midler til supplerende undervisning og anden faglig støtte, inklusionsfremmende initiativer og specialundervisning.

Der er fra 2013 til 2015 sket en reduktion i antallet af specialklasser fra 282 til 195 og en reduktion i antallet af specialskoler fra 19 til 15. Hvis man ser på elevtallet, er der i perioden sket en reduktion på 17,6 pct. i specialklasser og 15,4 pct. i specialskoler. Der har i de 12 kommuner været et generelt fald i elevtallet på 0,27 pct. fra 2013 til 2015. 
Alt i alt gælder for skoleforvaltningerne, at alle tolv kommuner har taget inklusionsopgaven op, og at man på forskellig måde har ydet en væsentlig indsats for at skabe fællesskab og ejerskab til inklusion fra forvaltningsniveau. Der er iværksat processer for at få skoleledere, skolebestyrelser, lærere og forældre med. Man har afholdt informationsmøder for alle forældre, og man har søgt en mere aktiv profilering af kommunens inklusionsstrategier i skriftlige materialer og på hjemmesider. I 2014 har der dog været en væsentlig "konkurrence" fra arbejdet med at implementere skolereformen, så inklusion står ikke længere som den mest centrale dagsorden.

\section{PPR}

PPR har spillet en væsentlig rolle i inklusionsbestræbelserne, og man har mange steder erkendt, at der er et klart behov for anderledes kompetencer i bemandingen end de traditionelt psykologiske. PPR har generelt også gennemgået en stor udvikling. Fra 2013 til 2015 er der endvidere en klar tendens til, at kommunerne arbejder på at udbygge det tværfaglige samarbejde på tværs af forvaltninger med henblik på at kunne støtte en tidlig indsats.

Visitationsprocesserne har fået mindre betydning ved overgangen til, at skolerne i høj grad selv skal finansiere specialtilbud. I 2015 er det et fælles træk for flere af PPRenhederne, at de arbejder på at etablere en hel fast struktur for, hvornår en elev kan indstilles til visitation. Dette sker for at sikre, at der arbejdes tilstrækkeligt med eleven i almenmiljøet.

I 2013 gjaldt, at PPR's placering som en central eller decentral enhed tæt på praksis rummede både fordele og ulemper. I 2015 er der i alle tilfælde sket en decentralisering enten til skoler eller til distrikter. Hvor sidstnævnte er sket, er også socialrådgivere og andet personale med støttefunktioner blevet flyttet ud. 


\section{Kvantitative resultater fra interview med skolechefer og PPR-ledere i de 12 kommuner}

\section{Skolechefer}

Skolecheferne er blevet stillet en række spørgsmål, hvor det har været muligt at foretage en kvantificering, og disse spørgsmål har dækket følgende områder: Inklusionsfremmende styringsmodeller, supplerende undervisning og anden faglig støtte, inklusionsindsatser (der forstås meget bredt som samtlige ekstraundervisningsressourcer, som skolerne tildeler klasserne, grupper af klasser eller enkelte elever udover, hvad der svarer til en lærer pr. klasse med udgangspunkt i skolens sædvanlige niveau for klassestørrelse), kompetenceopbygning, opbakning til inklusion og trivsel.

Resultaterne er opgjort i tabeller i Appendiks 1. I det følgende kommenteres resultaterne samlet.

\section{Inklusionsfremmende styringsmodeller}

Samtlige kommuner var i foråret 2013 i gang med at arbejde med inklusion. En enkelt kommune startede allerede i 2003, idet man i forlængelse af debatter om rummelighed skiftede fra et individfokus på vanskeligheder til at anvende en relationel synsvinkel. Flere kommuner kom i gang i forbindelse med introduktionen af LP-modellen i Danmark i 2007, og tankerne om inklusion har derfor ikke været fremmede, da lovgivningen om specialundervisning blev ændret fra august 2012. Det var således kun tre kommuner, der ikke inden 2012 havde etableret skriftlige målsætninger for inklusion. Målsætningerne var i de fleste kommuner også konkretiseret i praktiske tiltag.

Som følge af målsætningerne har alle kommuner arbejdet med tilpasning af kapaciteten på deres specialskoler, og man har først og fremmest søgt at undgå, at nye elever segregeres, men initiativer i forbindelse med hjemtagelse af elever i forbindelse med revisitation er også forekommet. Det samme har i endnu højere grad gjort sig gældende for specialklasser, og der er to tilfælde, hvor kommuner konsekvent har nedlagt specialklassetilbud. Dette er ikke sket, uden at der er overført ressourcer sammen med eleverne, men det er naturligvis blevet diskuteret, om der er fulgt ressourcer nok med.

Der er forskellige tilgange til, hvorvidt økonomiaftalen er styrende for forventningerne. I 2013 var der fire kommuner, hvor man ikke ville lade sig påvirke af et bestemt måltal, men i stedet ville se på de individuelle behov og muligheder, man fandt mest rimelige. I 2015 forholder man sig alle steder til økonomiaftalen, om end en enkelt kommune stadig ikke vil sigte efter et måltal, men blot har et ønske om at bevæge sig den 
rigtige vej. To kommuner har sat 98 pct. som måltal for inklusion i dagtilbuddene, idet det vil skabe mindre pres på at få et specialtilbud, når børnene skal starte i skolen.

Ni kommuner havde i 2013 etableret økonomiske incitamenter for inklusion, og i 2014 var det ti kommuner, der havde økonomiske incitamenter. I 2015 erkendes det i de sidste to kommuner, at incitamenter kan komme på tale. Fra PPR's side lyder der dog enkelte bekymringer for, at pengene kan blive mere bestemmende for processen end de faglige hensyn. De økonomiske incitamenter virker først og fremmest ved, at skolerne ikke segregerer eleverne til specialskoler og specialklasser, men forsøger at etablere nogle relevante undervisningsrammer og tilbud tilpasset eleven med særlige behov inden for egne rammer.

\section{Supplerende undervisning og anden faglig støtte}

Der var i 2013 to kommuner, der havde en kommunal plan for supplerende undervisning og anden faglig støtte til enkeltelever, mens de ti andre kommuner lod det være op til skolernes ledelser - støttet af lokal ekspertise og i de fleste tilfælde PPR - at administrere den supplerende undervisning. I 2014 havde alle 12 kommuner valgt, at det er den enkelte skoleleder, der har ansvaret, idet der dog er en forventning om, at skolelederne modtager vejledning fra PPR og kommunens konsulenter. En enkelt kommune har i 2015 indskrevet nogle forslag i deres politik, og skolechefen har dialogrunder med skolernes ledere.

\section{Inklusionsindsatser}

I 2013 havde halvdelen af kommunerne en kommunal plan for inklusionsindsatser, mens den anden halvdel overlod det til skolerne at afgøre, hvorledes midler til inklusionsindsatser anvendtes. I 2014 var tendensen klart, at ansvaret blev lagt ud til skolelederne, og der var kun to kommuner, der havde en overordnet kommunal plan. I den ene gik det på, at der lægges rammer for brug af tolærerordninger og holddannelse, i den anden blev der lagt vægt på, at man gerne ville prioritere indskolingen og have bragt Reading Recovery ind i almenundervisningen. I øvrigt nævnes i en kommune, at man forventer, at der er et samarbejde med PPR-lederen, og i en anden lægges vægt på, at skolelederne opretter studiegrupper, der ser på den seneste forskning om inklusion.

\section{Kompetenceudvikling og opbakning til inklusion}

Samtlige kommuner havde i 2013 etableret kompetenceudviklingsprogrammer, om end af meget forskellig karakter. I så godt som alle kommuner har man anvendt traditionelle former for kompetenceudvikling som pædagogiske dage og kurser for personalet, men i 
et flertal af kommuner har der også fundet andre former for kompetenceudvikling sted. Her kan nævnes gensidig supervision og besøg hos andre lærere. Brug af videooptagelser begynder også at vinde indpas, især inspireret af Marte Meo. Alle kommuner har også allerede inden inklusionsprocesserne gjort brug af ressourcepersoner på skolerne i form af lærere og pædagoger fra specialcenteret/kompetencecenteret, AKT-vejledere og læsevejledere. Der er også uddannet ressourcepersoner inden for inklusion. Ud over skolernes egne ressourcepersoner anvender kommunerne - med forskelligt held - personale fra specialskoler og specialklasser som rådgivere og vejledere. Som det allerede er nævnt, har der også været en betydelig anvendelse af pædagogiske modeller, først og fremmest LP-modellen.

Opbakning til inklusion har ikke kunnet kvantificeres ud fra skolechefernes svar, idet der for kommunerne er tale om en blanding af forskellige initiativer gående fra det, der sker ved kompetenceopbygning af personale, over medieomtale og møder med skolebestyrelser og forældre, men det gælder, at opbakningen i meget høj grad skabes af de enkelte skolers ledelse, og at det ikke har været en nem proces.

I 2014 har der i samtlige kommuner været fortsat fokus på kompetenceudvikling, og hvis der ikke tidligere var iværksat kompetenceudvikling for alle lærere, skete det $\mathrm{i}$ 2014, og i 2015 har flere kommuner fortsat en bred satsning på hele det pædagogiske personale. Der har i alle kommuner været fokus på at uddanne nøglepersoner, der i øvrigt kaldes mange forskellige ting, fra inklusionsagenter til inklusionsvejledere. I flere tilfælde har man givet AKT-lærere en opkvalificering enten ved skræddersyede kurser eller ved at give dem PD-moduler i specialpædagogik. Et gennemgående tema i alle tolv kommuner er dog, at det er vanskeligt for vejledere, ressourcepersoner og PPRmedarbejdere at videregive deres viden til det pædagogiske personale. Derfor har flere kommuner valgt at arbejde med, hvordan man vejleder voksne. Flere skolechefer nævner, at nogle lærere ikke ønsker vejledere ind i deres undervisning, men foretrækker at samarbejde med deres kolleger, helst gennem tolærerordninger.

Et andet, gennemgående træk er, at man har sat betydelige ressourcer af til kompetenceudvikling i inklusion, fx har en kommune sat $2.000 \mathrm{kr}$. ekstra af pr. medarbejder, mens andre har en større pulje fordelt over tre til fire år til støtte af inklusion.

I forhold til i 2013, hvor skolecheferne pegede på, at det ikke havde været en nem proces at få skabt opbakning til inklusion, var situationen i 2014 forværret betydeligt. Der oplevedes at være en betydelig modstand fra lærerside, der nogle steder nærmede sig decideret illoyalitet, hvor man udnyttede forældre og medier i en kamp mod inklusion. Baggrunden var konflikten i foråret 2013 og ændringer af lærernes arbejdstidsregler, der fulgte af L409. Man forventede også, at der ville gå lang tid, før modstanden var væk. I 2015 viser det sig, at der stadig er modstand på grund af L409, der yderligere 
suppleres af frustrationer i forbindelse med implementering af skolereformen samt $\mathrm{i}$ en del tilfælde afmagt, når lærere står med udfordringer i klassen, som er vanskelige at håndtere. Hvad forældregruppen angår, har skolebestyrelser og skoleledere gjort et stort arbejde for at skabe opbakning, der er i flere kommuner afholdt kurser for forældre og skolebestyrelser, og skolecheferne oplever i 2015, at der generelt er en god opbakning til inklusion især hos forældre til elever, der er blevet fastholdt i den almindelige undervisning eller er kommet tilbage fra specialskoler og specialklasser.

\section{Trivsel}

Graden af opbakning og succesen i gennemførelsen af inklusion må forventes at forplante sig til graden af trivsel.

Når skolecheferne i 2013 blev spurgt om trivsel, mente seks skolechefer, at de inkluderede elevers forældre syntes, at deres børn trivedes godt i det inkluderende skolemiljø. Tre svarede, at trivslen var nogenlunde, og ingen fandt den dårlig. Der var dog tre skolechefer, som erkendte, at de ikke vidste, hvordan trivslen var, da de enten havde været meget kort tid i forvaltningen, eller de følte, at de var for langt fra praksis. Fire skolechefer mente, at der blandt de øvrige forældre var en oplevelse af god trivsel for deres børn, mens syv vurderede den til at være nogenlunde. Kun en enkelt skolechef følte sig ikke i stand til at besvare spørgsmålet. Det generelle billede på skolechefniveau var dermed, at det var de almindelige elevers forældre, der havde den mindst positive oplevelse.

I 2014 havde skolecheferne overordnet set en opfattelse af, at forældre oplevede en bedre trivsel blandt deres børn end i 2013. For de inkluderede elevers forældres vedkommende vurderede syv skolechefer, at trivslen var god, og fem vurderede den til at være nogenlunde. For forældrene til elever uden særlige behov vurderede ni skolechefer trivslen som værende god og tre som nogenlunde. I 2015 er opfattelsen blandt skolecheferne stadig ganske positiv. Især har man den opfattelse, at forældre til de inkluderede elever har en positiv opfattelse af deres børns trivsel.

Hvad klager til forvaltningen angik, var der i 2013 fire kommuner, der ikke havde modtaget klager. Syv havde modtaget under tre klager, og blot en enkelt kommune havde modtaget mere end fem klager. I 2014 var der stadig fire skolechefer, der ikke havde oplevet klager til forvaltningen, men kun i to kommuner havde der været mere end fem klager. Tre af kommunerne havde ikke haft sager med forældreklager til klagenævnet, men kun tre af kommunerne havde haft mere end fem klager. I 2015 er billedet det samme, når det gælder klager til forvaltningen.

I forhold til klager til Klagenævnet for specialundervisning var der i 2013 tre kommuner, hvor der ikke havde været klager, fem, hvor der havde været under tre, en, hvor 
der havde været mellem tre og fem og tre med mere end fem klager. I 2014 var der seks kommuner uden klager, fire med under tre klager og to med mere end fem klager. I 2015 er billedet forrykket lidt i positiv retning, idet der nu kun er en kommune med mere end fem klager.

\section{PPR-ledere}

PPR-lederne er også blevet stillet en række spørgsmål, hvor det har været muligt at foretage en kvantificering, og disse spørgsmål har dækket: PPR's virksomhed, lederens uddannelse, lederens tilfredshed med inklusionsprocessen, visitations- og henvisningsmønstre og lederens oplevelse af elevtrivsel.

Resultaterne er opgjort samlet for alle 12 kommuner af hensyn til fortroligheden. Også disse resultater præsenteres talmæssigt som en række tabeller i Bilag 1. I det følgende kommenteres resultaterne samlet.

\section{PPR's virksomhed}

Overordnet kan det konstateres, at i 2013 havde PPR's forskellige ydelsestyper forskellig tyngde i de enkelte PPR-kontorer. Generelt gælder, at hvor man er organiseret i en familieforvaltning, vil det kun være en del af PPR's serviceydelser, der er orienteret mod skolen. I gennemsnit var det i 2013 omkring 60 pct. af PPR's virksomhed, der var skoleorienteret, og det rummede en variation fra 40 pct. til 80 pct. PPR's mest centrale kerneydelse var frem til august 2012 at foretage udredninger af elever. Disse fyldte i 2013 kun omkring en fjerdedel af arbejdstiden med en variation fra 7 pct. til 60 pct. Dette afspejlede dels forskelle i strategiske satsninger i kommunerne og på PPR, dels en vis træghed i psykologgruppen, der i en del tilfælde stadig så udredninger som den væsentligste professionelle identitet. Det gjaldt både for en del af de ældre psykologer med lang erfaring og for mange af de helt unge psykologer, som er uddannet på de traditionelle universiteter og ikke har en lærer- eller pædagogbaggrund. Danmarks Pædagogiske Universitets psykologuddannelse dimitterede de sidste kandidater, som havde lærer- eller pædagogbaggrund, i 2004, og nyrekruttering af psykologer til PPR, der ofte fungerer som første ansættelsessted i en psykologkarriere, sker derfor oftest direkte fra universiteternes psykologuddannelse, hvor pædagogisk psykologi fylder meget lidt, og de nyansattes kendskab til skolen udelukkende stammer fra deres egen skoletid.

Efter august 2012 skulle det, som før var PPR's sekundære ydelse, konsultativt arbejde, fylde mere, for at skolerne kunne levere supplerende undervisning og anden faglig støtte samt inklusionsindsatser til elever, der tidligere ville have fået mindre end 12 lektioners specialundervisning om ugen. Konsultativt arbejde blev i 2013 angivet til at 
omfatte ca. 30 pct. af PPR's virksomhed med et minimum på 10 pct. og et maksimum på 45 pct. Observation i klasser, der kan være et vigtigt instrument for god sparring med lærere, udgjorde knapt 10 pct. af PPR's arbejde, med en variation fra 3 pct. til ca. 20 pct. Forskellige indsatser af forebyggende karakter fyldte knapt en fjerdedel af PPR's virksomhed med en variation fra 4 pct. til hele 70 pct. Den store variation har baggrund i, at forebyggende opgaver kan defineres meget bredt og gå lige fra rådgivning af skolechef om inklusionsindsatser, der kan fx være tale om udpegning og uddannelse af inklusionsvejledere, over rådgivning af en skoleleder om brugen af tolærertimer og til samtale med en elev, der begynder at vise tegn på mistrivsel. Variationen hænger også sammen med, hvordan PPR's opgave er defineret. I 2015 er der stadig en meget stor variation i fordelingen af arbejdsopgaver i de tolv PPR-enheder. Det kan konstateres, at alle arbejder meget konsultativt. Flere af PPR-lederne nævner, at skolerne kan føle det udfordrende at arbejde med børn med særlige behov, der primært ligger hos det pædagogiske personale, mens dagtilbuddene er meget begejstrede for den konsultative bistand, da de oplever at have fået psykologerne meget tættere på.

Arbejdet med familier udgjorde i 2013 i gennemsnit 10 pct. af PPR's virksomhed med en variation fra 4 pct. til 23 pct., og det hænger naturligvis bl.a. sammen med, om PPR er organiseret i skoleforvaltningen eller i familieforvaltningen. I 2015 er tidlig indsats og fokus på hele familier et centralt udviklingspunkt i flere kommuner. To af kommunerne er ved at etablere familiehuse.

Det fremgik af interviews med PPR-lederne i 2013, at omkring halvdelen deltog i organisationsudvikling i kommunen, i udvikling af kommunens skoler og i kompetenceudvikling af skolens lærere. Om man deltog eller ikke deltog i sådanne aktiviteter, syntes at afhænge både af traditioner, af bemandingens kompetenceprofil og ikke mindst af lederens initiativ og samarbejde med skoleforvaltningen og skolelederne. I 2014 var organisationsudvikling i kommunerne blevet en større del af PPR's virksomhed, og det var nu ti af PPR-enhederne, som ydede denne service. I 2015 er antallet af PPR-enheder, der deltager i organisationsudvikling, faldet til de oprindelige otte, og dette skyldes primært omfattende kommunale omstruktureringer, hvor PPR slet ikke har været inde i billedet eller ligefrem har været en del af omstruktureringen.

I 2013 var der seks og i 2014 otte enheder, som arbejdede specifikt med skoleudvikling. I 2015 er der igen kun seks enheder, som arbejder med skoleudvikling. Reduktionen hænger sammen med implementeringen af skolereformen, da lederne oplever, at de enkelte skoler ikke har ressourcer eller overskud til at sætte nye tiltag i gang.

Der var i 2013 syv enheder, som varetog efteruddannelse af kommunens pædagogiske personale. Dette var steget til ni i 2014. Fem af PPR-enhederne har arbejdet med KL's pejlemærker for fremtidens PPR, og disse fem havde eller var ved at udarbejde 
ydelseskataloger, hvor der tilbydes målrettede kurser for det pædagogiske personale i kommunen. I 2015 er antallet reduceret til seks enheder. Dette forklarer lederne med, at L409 har gjort det meget vanskeligt at mødes med lærerne, samtidig med at skolereformen trækker mange ressourcer. Der opleves ikke at være overskud til nye tiltag.

På nær i en enkelt kommune var psykologerne i 2013 allokeret til bestemte skoler, og der var en vis variation i, om grupper af PPR's medarbejdere arbejdsmæssigt var samlet i distrikter, evt. sammen med socialrådgivere, eller om samlingspunktet var et centralt kontor, oftest placeret på rådhuset eller i en anden kommunal bygning, herunder rådhuse frigivet efter strukturreformen. I januar 2014 var PPR-medarbejderne i alle tolv kommuner allokeret til bestemte skoler eller bestemte distrikter. I flere af kommunerne arbejdedes der på en forbedring af det tværfaglige samarbejde, hvor sagsbehandlere var en del af distriktsteamet, således at man kunne sikre en mere helhedspræget tilgang til børn og unge samt deres forældre.

PPR-ledere berettede i 2013, at der var et stort ønske hos skolelederne om, at PPRmedarbejderne kunne yde en direkte støtte til lærerne til at etablere undervisningsmodeller for elever med forskellige særlige behov. Det erkendtes, at der var psykologer, som ikke magtede den ændrede rolle. Der sås en tydelig tendens i retning mod at ansætte færre psykologer og i stedet flere konsulenter med dels lærer- eller pædagogbaggrund, dels en pædagogisk overbygningsuddannelse på diplom-, master- eller kandidatniveau. Alle enheder havde været eller var i 2014 i gang med efteruddannelse af PPR's personale med henblik på at optimere det konsultative arbejde, og et andet gennemgående træk var, at der var fokus på, hvordan viden kunne gives videre. I 2015 går efteruddannelse ofte på at kunne give supervision og at lede møder. Flere PPR-ledere nævnte i 2014, at lærerne var blevet en mere sårbar gruppe at arbejde med efter konflikten, de nye arbejdstidsregler og usikkerhed omkring skolereformen. Det kom bl.a. til udtryk ved, at lærerne gerne ville have serveret færdige løsninger, hvor løsninger tidligere var baseret på gensidig refleksion. En PPR-leder mente, at PPR i det næste år ville få en væsentlig rolle i at skulle være organisatorisk understøttende frem for det direkte arbejde med børn og familier. Flere ledere nævnte også, at skolelederne var pressede på grund af de store ændringer og kommende forandringer. I 2015 viser det sig, at skoleledere og lærere er meget udfordrede af de mange, samtidige ændringer.

I 2013 var situationen således, at efterspørgslen efter ydelser havde en direkte indflydelse på normeringen i to kommuner. Der var dog ikke nogen tilfælde, hvor PPR var efterspørgselsstyret på den måde, at man var en selvstændig økonomisk enhed, der havde sine indtægter ved skolernes (og andres) køb af ydelser. I 2014 og 2015 var der ingen ændring, hvad angår normerings- eller efterspørgselsstyring. To af PPR-lederne gav dog allerede i 2014 udtryk for, at de gerne så, at PPR var efterspørgselsstyret, da de mente, at 
deres ressourcer ville blive brugt mere optimalt. I 2015 nævner yderligere to PPR-ledere, at de til dels er efterspørgselstyrede, da de arbejder på at få indført deres ydelseskataloger inspireret af KL's pejlemærker. Tre af kommunerne er dog gået væk fra at bruge ydelseskataloger, da medarbejderne forventningsafstemmer med de enkelte skoleledere, hvad de har brug for. De tre PPR-ledere nævner, at forandringerne på skolerne er så store, at skolernes behov varierer enormt, hvorfor det ikke giver mening at arbejde ud fra et ydelseskatalog.

\section{Lederens uddannelse og oplevelse af tilfredshed med PPR}

To tredjedele af PPR-lederne var i 2013 læreruddannede og havde en videreuddannelse som cand.pæd.psyk. En enkelt var cand.psych., og tre havde en anden baggrund, mens det indtil omkring 1990 var et krav, at en PPR-leder skulle have en læreruddannelse suppleret med en psykologuddannelse. Nogle skolechefer udtrykte i 2013, at de havde lettere ved at samarbejde med PPR, hvis lederen havde en forvaltningsbaggrund og dermed ikke identificerede sig med en enkelt af personalekategorierne. I 2014 var der seks PPR-ledere, der havde en uddannelse som cand.pæd.psyk., en var cand.psych., og tre havde en anden uddannelsesmæssig baggrund end psykolog. To stillinger var på interviewtidspunktet i januar under besættelse. I 2015 har syv PPR-ledere uddannelse om cand.pæd.psyk. og to som cand.psych. Tre har andre uddannelser end psykologi.

Ændringen af lovgivningen om specialundervisning i 2012 har som allerede nævnt betydet meget for PPR's arbejde og har krævet en stor omstilling. PPR-lederne sagde i to tredjedele af kommunerne i 2013, at brugerne oplevedes at være tilfredse eller meget tilfredse, mens der var usikkerhed om tilfredsheden i de sidste fire kommuner. Problemet syntes at være, at skolerne havde nogle forventninger om hurtig adgang til PPR's personale, ved at de hyppigt var på skolerne, og at man gerne ville have en mere didaktisk tilgang i PPR's rådgivning, som det aktuelle personale ikke var i stand til at levere. I 2014 var der en bedring i PPR-ledernes oplevelse af brugernes tilfredshed i forhold til 2013. Flere ledere nævnte, at synliggørelsen af deres ydelser var blevet mødt med positive tilkendegivelser fra det pædagogiske personale. Det oplevedes at have en positiv effekt, at PPR-medarbejderne var allokeret til enkelte skoler eller distrikter og dermed var mere synlige og tilgængelige. I 2015 oplever lederne en forskydning fra meget tilfreds til tilfreds, og at det primært skyldes, at brugerne i forvejen er meget pressede af L409 og skolereformen, samt at man ikke kan "komme af med" de elever, der giver vanskeligheder i dagligdagen. 


\section{Visitation}

I to kommuner havde man i 2013 etableret en visitationspraksis, hvor skolelederne ikke indgik direkte, hvad der dog ikke betød, at de slet ikke blev taget med på råd. I de øvrige kommuner indgik skolelederne enten meget eller særdeles meget. Der var i øvrigt en oplevelse af, at skolelederne inden inklusionsprocessen generelt havde for stor indflydelse på mulighederne for segregering, muligheder, der betød, at segregering havde en betydelig indflydelse på de fleste skolers økonomi. I 2014 var det sådan, at skolelederne indgik mere direkte i visitationsprocessen, hvad der også var et resultat af, at ansvaret for brugen af ressourcer og arten af indsatser over for elever med særlige behov lå hos skolelederen, og dette gælder også i 2015. To af PPR-lederne udtrykte en grad af betænkelighed over for dette; den ene var bekymret for, at de økonomiske incitamenter kunne betyde, at de prioriteredes højere end elevens tarv, den anden beskrev, at PPR til tider ikke mente, at der var arbejdet tilstrækkeligt omkring eleven, inden denne indstilledes til et andet tilbud. Samme reservationer gælder for de to i 2015. I 2015 udtrykker flere af PPR-lederne bekymring for de inkluderede elevers faglige udvikling og trivsel. De siger, at det kvantitative mål om 96 pct. nok er opfyldt, men hvordan står det til med de kvalitative mål?

PPR-lederne oplevede i 2013 for godt halvdelen af kommunernes vedkommende, at visitationsprocessen fungerede godt i forhold til tilbudsviften. I to kommuner mente lederne, at processen slet ikke fungerede. I den ene spillede PPR en ret perifer rolle i forhold til at vælge i tilbudsviften, i den anden ønskede en ret ny PPR-leder, at der blev lagt en ny strategi. I et flertal af kommunerne hang budgetansvar og visitation sammen. Kun i to kommuner var der ikke nogen sammenhæng, og det var i de samme to kommuner, at lederne mente, processen ikke fungerede. I to tredjedele af kommunerne indgik et samlet hensyn til befordring og fritidstilbud i de faglige hensyn i visitationen, mens det $\mathrm{i}$ den sidste tredjedel af kommunerne slet ikke indgik. Der var kun en enkelt kommune, hvor økonomiske hensyn til befordring og fritidstilbud ikke indgik samlet i visitationen. Generelt fandt to tredjedele af lederne, at de var tilfredse med visitationsprocessen, fem var endda meget tilfredse. En enkelt var utilfreds, og tre var meget utilfredse. Utilfredshed kom primært fra relativt nyansatte ledere, der gerne så en anden struktur, samt kommuner, hvor visitationen var delt mellem to forvaltningsenheder. Der var i 2014 et indtryk af, at visitationen fungerede bedre i forhold til tilbudsviften end i 2013. Det oplevedes, at budgetansvar og visitation hang godt sammen, hvad der igen var et resultat af, at skolelederne havde fået en nøglefunktion på begge områder. Hvad angik den samlede indflydelse, befordring og fritidstilbud havde på de faglige og økonomiske hensyn i visitationen, var der ikke sket ændringer over de tre år. PPR-ledernes generelle tilfredshed 
med visitationsprocessen var øget væsentligt fra 2013 til 2014, og den er i 2015 på samme niveau.

Der syntes endnu ikke i 2013 at være lagt væsentligt ændret vægt på revisitationsmønstret, idet man, som det nævnes i det følgende, først og fremmest arbejdede mod at begrænse nyhenvisninger til specialtilbud. En undtagelse var naturligvis de steder, hvor man helt havde nedlagt specialklasser. I 2014 var der fortsat ikke væsentligt ændret på revisitationsmønstret. En enkelt leder beskriver dog, at de arbejder på, at skolelederne på de lokale distriktsskoler skal deltage i revisitationen, således at der skabes mulighed for, at skolelederen kan vurdere, om et tilstrækkeligt undervisningsforløb kan etableres for den pågældende elev på den lokale almenskole. Heller ikke i 2015 er der ændret væsentligt på revisitationsmønsteret.

\section{AEndret henvisningsmønster}

PPR-lederne oplyste i 2013, at der kun i to kommuner ikke var sket en reduceret henvisning til specialskoler og specialklasser. I tre kommuner var der sket en lille reduktion, i tre andre nogen reduktion, i to megen reduktion og i én særdeles megen reduktion. Tilbageflytning af elever fra specialtilbud forekom ifølge PPR-lederne ikke i to kommuner. Fire kommuner havde en lille tilbageflytning, tre havde nogen tilbageflytning, en havde megen tilbageflytning, og to havde særdeles megen tilbageflytning. I 2014 var der sket en markant ændring i henvisningsmønsteret i de fleste kommuner, idet der først og fremmest henvistes færre til specialskoler. I nogle kommuner var det besluttet, at man slet ikke henviste til specialskoler mere. I 2015 er der et enkelt sted sket en fordobling af antallet af indstillinger, hvilket man mener skyldes, at PPR er blevet mere synlig end i de to foregående år. I de kommuner, hvor der er udarbejdet nye regler for indstilling til visitation, nævnes det af flere PPR-ledere, at det er vanskeligt at få skoleledere og lærere til at følge de nye retningslinjer, at der skal være arbejdet fyldestgørende omkring eleven med undervisningsdifferentiering, supplerende undervisning og anden støtte samt inklusionsforanstaltninger, før der kan foretages en indstilling.

\section{Trivsel}

I forhold til, hvordan forældre til inkluderede elever oplever deres børns trivsel, fandt otte PPR-ledere i 2013, at der var en nogenlunde trivsel, mens to mente, at den var god. Ingen PPR-ledere udtrykte, at den var særdeles god. En af lederne mente, at trivslen var dårlig, mens en relativt nyansat leder ikke så sig i stand til at svare på spørgsmålet. I 2014 fandt seks PPR-ledere, at der var god trivsel, mens tre fandt, at den var nogenlunde. To fandt den dårlig, og en så sig ikke i stand til at besvare spørgsmålet. Der var dermed 
tale om en markant bedring i forhold til 2013. I 2015 er vurderingen for ni af PPR-lederne gennemsnitligt bedre, men tre af lederne ser sig ikke i stand til at besvare spørgsmålet, da de har mindre direkte kontakt med eleverne og forældrene, end de havde tidligere.

Forældre til de øvrige elever i klasserne oplever ifølge PPR-lederne i 2013, at deres børn havde en god trivsel i fire kommuner, en nogenlunde trivsel i syv kommuner. Ingen fandt, at der var tale om en dårlig trivsel. En af lederne så sig ikke i stand til at svare på spørgsmålet. I 2014 mente PPR-lederne, at forældre til elever uden særlige behov oplevedes at have et lidt dårligere billede af deres børns trivsel end i 2013. Således mente kun to ledere, at den var god, mens otte ledere fandt den nogenlunde. En fandt den dårlig, mens en ikke var i stand til at svare. I 2015 er der nu fem PPR-ledere, der ikke er i stand til at svare på grund af den større distance til forældre og elever, for de øvrige syv er der tale om vurderinger, som er på stort set på samme niveau som i 2014.

\section{Klager til PPR}

I 2013 var der tre PPR-enheder, som ikke havde modtaget klager vedrørende inklusion fra forældre, fire, som havde fået 1-2 klager, fire, som havde fået 3-5 klager, og en, som havde fået mere end fem klager. I 2014 var antallet uden klager øget til seks, mens der var fire med 1-2 klager, en med 3-5 klager og en med mere end fem klager. Der var dermed sket en tydelig reduktion i antallet af klager i 2014. For 2015 gælder, at antallet af klager er øget. Fire enheder har ingen klager, en har 1-2 klager, seks har 3-5 klager, og en har mere end fem klager. Klagerne går typisk på, at forældre ønsker at få specialundervisning (mere end 12 timer om ugen) til deres børn, da de ikke er tilfredse med den supplerende undervisning eller faglige støtte, som skolen tilbyder, eller at de ønsker et andet specialundervisningstilbud end det, de har fået.

\section{Inklusionsindikatorer}

Ud over de kvalitative interview med skolechefer og PPR-chefer og de administrative baggrundsdata fra skoleforvaltningerne er der i forbindelse med undersøgelsen foretaget en dokumentanalyse af materialer fra kommunerne vedrørende inklusionsprocessen. Analysemetoden har, ud over de kvantitative data, været afsøgning af temaer, dvs. forhold, der går igen på tværs af kommuner. Det er lykkedes at identificere seks indikatorer for inklusionsarbejdet i kommunerne. De første fem er procesindikatorer, hvormed menes indikatorer for, hvordan og med hvilken kvalitet man har arbejdet med inklusionsprocessen. Den sidste er en resultatindikator, idet den fortæller, hvordan inklusionsprocenten faktisk er ændret i forhold til KREVI's opgørelse fra 2009/10 (KREVI, 2011). I undersøgelsens kvantitative analyser anvendes yderligere en indikator, nemlig kommuneres socialøkonomiske indeks. 
Det gælder om de første seks inklusionsindikatorer, at de skal betragtes som baseline-niveauer i den første statusrapport, som den anden og den sidste (nærværende) statusrapport drager sammenligninger med. I sidste del af rapporten vil de seks faktorer blive sammenholdt med udsagn fra skoleledere, skolebestyrelsesformænd og lærere, mens der er et for spinkelt datamateriale fra elever til, at der ud over i forhold til trivsel er mulighed for at foretage analyser i forhold til inklusionsindikatorer.

De seks indikatorer er:

- Startår for inklusionsprocessen

- Grad af fælles værdigrundlag på forvaltningsniveauet

- Grad af kompetenceudvikling

- Grad af økonomiske incitamenter

- Kvalitet af samarbejde mellem skoleforvaltning og PPR

- Endring i inklusionsprocenten fra 2010 til 2013.

Om startår for inklusionsprocessen gælder, at der er taget udgangspunkt i, hvornår man rent faktisk er gået i gang. Det er således ikke nok, at der har været debatteret rummelighed eller har været arbejdet med fx LP-modellen, og at man har defineret begrebet inklusion, som det illustreres i Bilag 1, tabel 1. Man skal rent faktisk have startet på kompetenceudvikling, ændring af procedurer omkring inklusion/segregering eller organisationsændring i specialiserede tilbud. Analyse af dette viser, at kommunerne fordeler sig som følger:

Tabel 23. Årstal for start på inklusionsprocessen

\begin{tabular}{|l|l|}
\hline Årstal for start på inklusionsprocessen & Antal kommuner \\
\hline 2011 & 7 \\
\hline 2012 & 3 \\
\hline 2013 & 2 \\
\hline
\end{tabular}

Kilde: Interview med skolechefer

Tabellen over årstal for start på inklusionsprocessen viser, at flertallet af kommuner er gået $\mathrm{i}$ gang året inden, lovændringen trådte i kraft. Det er også et gennemgående træk i disse kommuner, at man har studeret Deloitte-rapporten (2010) og faktisk var i gang med at etablere økonomiske incitamenter for inklusion. Tre kommuner kom i gang $\mathrm{i}$ året, hvor loven trådte i kraft, og to kommuner er først kommet rigtigt i gang i 2013. Det er i øvrigt karakteristisk for en del af kommunerne, at inklusionsprocessen har fundet sted parallelt med skolestrukturelle ændringer, herunder nedlæggelse af en række små skoler, og i øvrigt parallelt med, at der har skullet ske generelle besparelser. Der er naturligvis ikke sket en ændring af denne inklusionsindikator efter 2013. 
Vurderingen af graden af fælles værdigrundlag på forvaltningsniveau hviler på udsagn fra skolechefer og PPR-ledere samt dokumentanalyse. Der er her lagt vægt på, om der er enighed i skoleforvaltningen og i PPR, og i hvilken grad denne enighed er formidlet videre til skolernes ledelser, lærere, forældre og elever. Skolelederne, bestyrelsesformændene og lærernes kvantitative svar indgår ikke i vurderingen, men er udgangspunkt for en selvstændig behandling senere i rapporten.

Tabel 24. Graden af fælles værdigrundlag på forvaltningsniveau

\begin{tabular}{|l|l|l|l|l|}
\hline $\begin{array}{l}\text { Grad af fælles vær- } \\
\text { digrundlag på for- } \\
\text { valtningsniveau }\end{array}$ & $\begin{array}{l}\text { Antal kommuner } \\
2013\end{array}$ & $\begin{array}{l}\text { Antal kommuner } \\
2014\end{array}$ & $\begin{array}{l}\text { Antal kommuner } \\
2015\end{array}$ \\
\hline Høj & 8 & 7 & 9 \\
\hline Mellem & 1 & 4 & 3 \\
\hline Lav & 2 & 1 & 0 & \\
\hline
\end{tabular}

Kilde: Interview med skolechefer og PPR-ledere

Allerede i 2013 var der i hovedparten af kommunerne tale om en høj grad af fælles værdigrundlag. For de tre kommuner, hvor graden af fælles værdigrundlag vurderedes at være mellem eller lav, gjaldt, at der ikke helt var enighed om inklusionsstrategien mellem skolechef og PPR-leder, eller at man først lige var startet på at føre den ud i livet i slutningen af 2012 eller begyndelsen af 2013. Der var kun 11 kommuner i tabellen for 2013, da en enkelt kommune kun lige var startet, og det derfor ikke var muligt at vurdere graden af fælles værdigrundlag. I 2014 var der en kommune, der var rykket ned fra høj til mellem, da der var ved at ske en større omorganisering i forvaltningen. Der var en kommune, der var rykket fra lav til mellem, og der lå nu fire kommuner i denne kategori. Det var dog kendetegnende for kommunerne, at der på såvel forvaltnings- som PPRniveau arbejdedes ihærdigt med at videreudvikle og formidle målsætningerne for inklusionsprocessen. I de syv kommuner med højt fælles værdigrundlag, var implementeringsprocessen i fokus. I 2015 er der sket en markant positiv udvikling, idet der nu er ni kommuner med høj grad af fælles værdigrundlag, tre kommuner med mellemhøj grad af fælles værdigrundlag og dermed ingen kommuner i den lave kategori.

For kompetenceudvikling gælder, at kommunerne rubriceres på højt niveau, hvis der er taget fat på en markant kompetenceudvikling på alle niveauer - ledelse, specialister og medarbejdere - tidligt i processen. Ved mellemniveau forstås, at man er startet senere i processen, at indsatsen ikke har været markant, eller at kompetenceudviklingen ikke har dækket alle niveauer. Ved lavt niveau forstås, at man først er kommet sent i gang eller endnu ikke for alvor er startet. Rubriceringen er sket på baggrund af interview med skolechef og PPR-leder samt dokumentanalyse. 
Tabel 25. Kompetenceudviklingsniveau

\begin{tabular}{|l|l|ll|ll|}
\hline $\begin{array}{l}\text { Kompetenceudvik- } \\
\text { lings-niveau }\end{array}$ & $\begin{array}{l}\text { Antal kommuner } \\
2013\end{array}$ & $\begin{array}{l}\text { Antal kommuner } \\
2014\end{array}$ & $\begin{array}{l}\text { Antal kommuner } \\
2015\end{array}$ & \\
\hline Højt & 9 & 9 & 9 \\
\hline Mellem & 1 & 3 & 3 \\
\hline Lavt & 2 & 0 & 0 \\
\hline
\end{tabular}

Kilde: Interview med skolechefer

Det gjaldt i 2013, at der i ni af kommunerne havde været en markant indsats med kompetenceudvikling på alle niveauer, og at det var sket tidligt i processen. I en enkelt kommune var indsatsen vurderet som 'mellem' og igangsat inde i processen. For to kommuner gjaldt, at man i den ene var kommet ret sent i gang, og at man i den anden først for alvor var ved at komme i gang. I 2014 blev der fortsat fokuseret markant på kompetenceudvikling. De tre kommuner i mellemkategorien var alle i gang med at styrke og udvikle personalets kompetencer, og PPR var som tidligere nævnt også sat markant ind på området. I 2015 er niveauet det samme som for 2014.

Økonomiske incitamenter for inklusion er en parameter med en stor variation i type og omfang, og mange kommuner har prøvet sig frem med sådanne incitamenter siden 2007. Incitamenterne for de 12 kommuner i Dokumentationsprojektet er på baggrund af interview med skolecheferne placeret i tre mulige kategorier, høj, hvor der er en klar økonomisk konsekvens for skoler af at segregere/inkludere elever, mellem, hvor der er en mere beskeden konsekvens, ved at der i betydelig grad kan trækkes på en central pulje eller forsikringsordning, og lav, hvor der ikke er etableret et økonomisk incitamentssystem.

Tabel 26. Grad af økonomiske incitamenter for inklusion

\begin{tabular}{|l|l|ll|l|}
\hline $\begin{array}{l}\text { Grad af økonomisk } \\
\text { incitamentsstruktur }\end{array}$ & $\begin{array}{l}\text { Antal kommuner } \\
2013\end{array}$ & $\begin{array}{l}\text { Antal kommuner } \\
2014\end{array}$ & $\begin{array}{l}\text { Antal kommuner } \\
2015\end{array}$ \\
\hline Høj & 9 & 10 & 10 \\
\hline Mellem & 0 & 0 & 0 \\
\hline Lav & 3 & 2 & 2 \\
\hline
\end{tabular}

Kilde: Interview med skolechefer

To tredjedele af kommunerne havde i 2013, som det allerede er fremgået tidligere i rapporten, etableret forskellige former for ganske markante økonomiske incitamenter. Tre kommuner havde ikke etableret et økonomisk incitamentssystem, men en af kommunerne forventede, at det var undervejs. I 2014 var der ti kommuner, der anvendte økonomiske incitamenter, mens to kommuner bevidst afstod fra at gøre det. De to kommuner var 
i øvrigt stolte af, at det kunne lade sig gøre uden. I 2015 er situationen den, at der i den ene kommune begynder at være blandede politiske signaler om nødvendigheden af incitamenter, mens en nyansat skolechef i den anden kommune erkender, at der må tages fat på spørgsmålet.

Samarbejde mellem skoleforvaltning og PPR har en vis sammenhæng med, om der eksisterer et fælles værdigrundlag, men også andre faktorer spiller ind. Dels samarbejdsrelationen mellem skolechef og PPR-leder, dels den forvaltningsmæssige placering, hvor placering i en anden forvaltning eller på tværs af forvaltninger kan gøre samarbejdet udfordrende.

Tabel 27. Graden af kvalitet i samarbejdet på forvaltningsniveau

\begin{tabular}{|l|l|ll|ll|}
\hline $\begin{array}{l}\text { Kvalitet af samar- } \\
\text { bejdet }\end{array}$ & $\begin{array}{l}\text { Antal kommuner } \\
2013\end{array}$ & $\begin{array}{l}\text { Antal kommuner } \\
2014\end{array}$ & $\begin{array}{l}\text { Antal kommuner } \\
2015\end{array}$ & \\
\hline Høj & 7 & 8 & 8 \\
\hline Mellem & 2 & 3 & 4 & \\
\hline Lav & 3 & 1 & 0 & \\
\hline
\end{tabular}

Kilde: Interview med skolechefer og PPR-ledere

I 2013 vurderedes kvaliteten af samarbejdet i syv kommuner til at være høj, i to mellem og i tre lav. I øvrigt vurderedes det, at udskiftninger af ledere formodedes at fremme kvaliteten af samarbejdet over de kommende år. I 2014 var der sket en forbedring af kvaliteten af samarbejdet på forvaltningsniveauet. Det vurderedes, at udskiftningen af ledere, PPR's udarbejdelse af ydelseskataloger og deres aktive deltagelse i kommunens organisations- og kompetenceudvikling alle var faktorer, der havde påvirket kvaliteten af samarbejdet i en positiv retning. I 2015 er der sket en yderligere bedring, idet en kommune er rykket fra lav til mellemkategori.

Ændret inklusionsprocent kan siges at være en nøglefaktor i forhold til kommuneaftalen for 2013, hvis ordlyd er: Andelen af elever, der skal inkluderes i den almindelige undervisning, øges. Målet er således, at andelen af elever i almindelig undervisning i 2015 er forøget fra 94,4 pct. til 96,0 pct. af det samlede elevtal i folkeskolen. Ændringen skal naturligvis ses i forhold til, hvor langt man i 2010 lå fra kommuneaftalens mål.

Den nøjagtige inklusionsprocent fremgår af skoleportrætterne tidligere i denne rapport. Hvis man opdeler i intervaller, opnås følgende fordeling. 
Tabel 28. Fndret inklusionsprocent fra 2009/10 til 2013, 2009/2010 til 2014 og fra 2009/10 til 2015

\begin{tabular}{|l|l|l|l|}
\hline $\begin{array}{l}\text { Endret inklusions- } \\
\text { procent }\end{array}$ & $\begin{array}{l}\text { Antal kommuner } \\
2013\end{array}$ & $\begin{array}{l}\text { Antal kommuner } \\
2014\end{array}$ & $\begin{array}{l}\text { Antal kommuner } \\
2015\end{array}$ \\
\hline $\begin{array}{l}\text { Mindre end 1 pro- } \\
\text { centpoint }\end{array}$ & 4 & 3 & 1 \\
\hline $\begin{array}{l}\text { Fra 1 til 2 procentpo- } \\
\text { int }\end{array}$ & 4 & 3 & 2 \\
\hline $\begin{array}{l}\text { Mere end 2 procent- } \\
\text { point }\end{array}$ & 4 & 6 & 9 \\
\hline
\end{tabular}

Kilde: Administrative oplysninger fra kommunerne senest i januar 2015

Allerede i 2013 viste det sig, at alle kommuner havde øget inklusionsprocenten fra 2009/10 til 2013. I alt placerede fire kommuner sig i kategorien med op til 1 procentpoint, fire kommuner havde en stigning på mellem 1 og 2 procentpoint, og fire kommuner havde en stigning på mere end 2 procentpoint; den højeste var på hele 4,5 procentpoint. Den gennemsnitlige stigning udgør 1,8 pct. I 2014 var der sket en yderligere inklusion, således at der kun var tre kommuner, der havde en ændring på mindre end 1 procentpoint i forhold til 2019/10. Der var også kun tre kommuner, der havde fra 1 til 2 procentpoints ændring, mens halvdelen af kommunerne lå over 2 procentpoint. For 2015 gælder, at ni kommuner har ændret inklusionen mere end 2 procentpoint, to ligger fra 1 til 2 procentpoint, og kun en ligger med mindre end 1 procentpoint.

Den gennemsnitlige inklusionsprocent i de 12 kommuner var i 2009/10 på 93,1 pct. og var i 2013 steget til 94,9 pct., og fem af kommunerne lå nu over aftalens gennemsnit på 96 pct. for 2015. Den gennemsnitlige inklusionsprocent var i starten af 2014 på 95,5 pct., 0,5 procentpoint under målet for 2015. I 2015 er målet på 96 pct. nået. 


\section{Sammenfatning, Del 1, skolechefer, PPR og skoleforvaltninger}

De 12 kommuner, der er udvalgt til undersøgelsen, dækker et bredt spektrum af den variation, der findes i de 98 danske kommuner. Der er storbykommuner, forstadskommuner, omegnskommuner og landkommuner. Der er velstillede kommuner og kommuner med et relativt lavt socioøkonomisk niveau. Der er kommuner med en høj grad af satsning på offentlig service, herunder på skoleområdet, og der er kommuner, hvor der findes udfordringer $\mathrm{i}$ forhold til at tilbyde fx folkeskolens minimumstimetal. Der er kommuner, hvor man ikke har rørt nævneværdigt ved skolestrukturen, og kommuner, der har gennemført omfattende ændringer.

Mest interessant i nærværende sammenhæng er, at kommunerne i skoleåret 2009/10 havde en forskellig inklusionsgrad forstået som andelen af elever inkluderet i folkeskolens almindelige klasser. Nogle relativt få har haft en høj grad af inklusion, mens andre har ligget $\mathrm{i}$ bunden af landsgennemsnittet. De store forskelle taget i betragtning kan det heller ikke undre, at der er store forskelle i den måde, hvorpå man har grebet inklusionsprocessen an.

Nogle kommuner har været meget tidligt i gang, og det har typisk været med at ændre et individfokuseret fejlfindingssystem til et systemisk syn på de omstændigheder, der gør, at elever kommer i vanskeligheder i skolen. Især den såkaldte LP-model, samt kopimodeller, er slået stærkt igennem. En del kommuner har også arbejdet systematisk med den rummelighedstænkning, som allerede slog igennem omkring 2000. Selve arbejdet med at starte en inklusionsproces strækker sig fra 2011 for de tidligste kommuner, et år før lovændringen i august 2012, over 2012, hvor Regeringen og KL indgik aftale om kommunernes økonomi for 2013, og til 2013, hvor de sidste kommuner kom i gang for alvor.

I forhold til de kommuner, der er kommet sent i gang, berettede nogle skolechefer i 2013, at der i nogle kommuner, især landkommuner med mange små skoler, havde været en eksklusionskultur støttet af ønsket om specialiserede tilbud til elever med faglige og sociale vanskeligheder - og manglende overblik over økonomien. Eksklusion blev belønnet. Lærerne og deres klasser og skolelederne slap af med udfordrende elever, og tendensen blev støttet af en fejlfindingskultur hos PPR samt retskrav på den specialpædagogiske bistand. Det var karakteristisk, at ingen protesterede over den øgede segregering, og det var først efter undersøgelsen af folkeskolens specialundervisning (Deloitterapporten), at man fik øje på udgiftsniveauet.

I 2014 arbejdede kommunerne fortsat med inklusion, men var forskellige steder i omstillingen. Målsætningerne var etableret i alle kommuner, og mens de kommuner, der 
startede tidligst, var i gang med implementeringen, var de senest startende kommuner i færd med at færdiggøre arbejdet med strategierne. PPR var i meget høj grad kommet i spil med konsultativ virksomhed og tilbud om kompetenceudvikling til det pædagogiske personale og organisationsudvikling i kommunen. Det at arbejde konsultativt er fortsat i fokus på alle 12 PPR-kontorer. Det er tydeligt, at det at arbejde med inklusion har været og fortsat er en udviklingsproces, og alle kommuner bærer præg af, at inklusion er gået fra et overordnet ideal til at være en del af praksis. I 2015 har man fortsat udviklingen mod inklusion, men det parallelle arbejde med at implementere skolereformen har flyttet fokus noget.

De kommuner, der har været tidligst i gang, har også iværksat forudgående kompetenceudviklingsprogrammer for medarbejderne, før inklusionen er sat i gang rent organisatorisk. I de kommuner, der er gået i gang senere, er kompetenceudvikling og organisatoriske ændringer nærmest gået hånd i hånd. Der er ingen kommuner, der ikke har søgt at give personalet kompetenceløft, og der har været afsat betydelige økonomiske ressourcer hertil. I 2013 var der i gennemsnit budgetteret med $381 \mathrm{kr}$. pr elev, mens der i 2014 var afsat 481 kr. pr. elev og i 2015304 kr. pr. elev. Desuden er der i flere kommuner afsat ressourcer fra PPR og videnscentre til kompetenceudvikling, uden at disse beløb indgår i det egentlige budget for kompetenceudvikling i inklusion. Det almindelige billede er, at man har haft et relativt kortvarigt forløb for samtlige medarbejdere og derudover har uddannet et korps af vejledere, der går under mange betegnelser. De kommuner, der har været tidligst i gang, er kendetegnet ved at have et højt generelt ressourceforbrug og/eller en dynamisk ledelse, hvor PPR spillede en særlig rolle som facilitator, og som nævnt er PPR en aktiv medspiller eller forsøger på at blive det i alle kommuner. De kommuner, som er kommet relativt sent i gang, er generelt kendetegnet ved at være blandt kommunerne med de største økonomiske udfordringer. Her ses meget drastiske ændringer af skolestruktur med nedlæggelse og sammenlægning af skoler og i et enkelt tilfælde total nedlæggelse af samtlige specialklassetilbud, hvad der har skabt en betydelig modstand.

Selv hvor inklusionsprocessen har været omfattende, er den dog ledsaget af, at man har ladet ressourcer følge med over i den almene undervisning, og at man har sørget for en eller anden opkvalificering af personalet. Nogle steder har man ligefrem relativt set - i forhold til de øvrige budgetter i kommunen - tilført ressourcer til inklusionsprocessen. Det er i det hele taget et generelt billede, at økonomiske incitamenter sammen med lovændringens nydefinering af specialundervisning spiller en meget stor rolle for, at inklusionsprocessen er kommet så vidt, som det faktisk er tilfældet, fra 93,1 pct. i 2010 til 94,9 pct. i 2013, 95,5 pct. i 2014 og 96,0 pct. i 2015. Det er dermed lykkedes at vende 
den tendens til stigende eksklusion, der har været til stede fra midt i 1990'erne, og som for alvor tog fart fra 00'erne med en yderligere stærk vækst efter strukturreformen i 2007.

Den mekanisme, hvormed man lader ressourcerne følge over i almenundervisningen, giver imidlertid let anledning til uigennemskuelighed for personalet på den enkelte skole. Ressourcetildelingen sker med udgangspunkt i skolens elevtal og i de fleste tilfælde en ekstra pulje, som afspejler skoledistriktets socialøkonomiske baggrund, og den fordeles med midler til specialundervisning (på mere end ni timer pr. uge) på skolen, til betaling for elever i specialklasser uden for skolen og i specialskoler, til supplerende undervisning og anden faglig støtte (til enkeltelever) og inklusionsfremmende foranstaltninger, men herefter overlades det til skolelederne at kanalisere midlerne ud. Det er en krævende opgave at fordele disse ressourcer, og det kan let føre til, at nogen bliver forbigået, og enkelte PPR-ledere føler, at der let tages mere hensyn til økonomi end til faglige behov.

Hvad økonomi angår, skal det tages i betragtning, at flere kommuner gennem de senere år som følge af den økonomiske krise har været gennem generelle besparelser. Tre af de tolv kommuner havde et højere budget pr. elev i 2013 end i 2012, og ni kommuner havde et mindre budget. For perioden 2013 til 2015 har der kun været marginale ændringer i budgetterne pr. elev. I 2014 gjaldt, at fem kommuner havde et større budget end i 2013, en kommune havde samme budget, mens seks kommuner havde et mindre budget. Når man så på den del af budgettet, der gik til elever med særlige behov, herunder både specialundervisning, supplerende undervisning og anden faglig støtte samt inklusionsfremmende initiativer, var der dog tale om en øgning af budgettet fra 2013 til 2014 på 1,1 procentpoint. I 2015 har decentraliseringen af brug af alle midler til elever med særlige behov medført, at andelen kun kan opgøres for tre kommuners vedkommende, og i disse er der ingen forskydninger.

Mens budgettal siger noget om prioriteringer, giver nettodriftsudgifter et mere retvisende billede af ressourceforbruget. Det gælder her, at der som gennemsnit har været en øgning i udgifterne pr. elev på 1,4 pct. i faste priser fra 2012 til 2014, men med en betydelig variation kommunerne i mellem.

I forbindelse med de nye arbejdstidsregler for lærere fra august 2014 er der helt gennemgående blevet satset på, at man vil have tilstedeværelse, fuld eller delvis, og hensigten med dette er først og fremmest at øge mulighederne for et tæt teamsamarbejde, herunder sikre et godt samarbejde mellem lærere og pædagoger.

Hvis man i 2013 ikke decideret havde nedlagt specialtilbud, havde man næsten alle steder søgt at ændre segregeringstraditioner ved at undgå henvisning af de yngste elever til specialtilbud og i nogle tilfælde også søgt at hjemtage elever ved at lade ressourcer tilgå den almindelige klasse. Samme tendens sås også i 2014, hvor der ikke var ændret på 
antallet af specialskoler, men der var dog sket en reduktion i antallet af specialklasser på 15 pct. Ni af kommunerne havde reduceret antallet af specialklasseelever fra 2013 til 2014. Fra 2014 til 2015 er der sket en reduktion af antallet af specialskoler på fem, og der er sket en reduktion af specialklasser på 24 pct.

Fællesskab om og ejerskab til inklusion var allerede i 2013 - eller tidligere - søgt sikret på mange forskellige måder, og i de fleste kommuner var der ydet en stor indsats for at få skoleledere, skolebestyrelser, lærere og forældre med. Det var dog også klart, at jo længere væk man kom fra forvaltningerne, des sværere var det, og nogle lærere og forældre har været svære at få med på idéen, og der var også en del eksempler på forældreklager. Langt de fleste kommuner havde produceret informationsmateriale, der oplyste om idéerne og fordelene ved inklusion. I 2014 har flere kommuner afholdt informationsmøder for alle forældre, og man har søgt en mere aktiv profilering af kommunens inklusionsstrategier i skriftlige materialer og på hjemmesider. Der har i 2014 været en del tilfælde, hvor inklusion har fået en dårlig omtale i medier, dels på baggrund af indslag i TV, dels i de trykte medier på baggrund af opinionsmålinger, hvor såvel lærere som forældre udtrykker bekymring for inklusion, og i nogle tilfælde er lærerkredse og forældre gået sammen i en alliance mod inklusion. Det er et gennemgående indtryk hos skolechefer og PPR-ledere, at denne modstand først og fremmest har baggrund i konflikten om lærernes arbejdstid i foråret 2013, men at usikkerheden om skolereformen også spiller ind. I 2015 har der fortsat været en overvejende negativ omtale af inklusion i medierne. Skolechefer og PPR-ledere giver fortsat udtryk for, at lærerne generelt føler sig udfordret af inklusionsopgaven, men at dette nu ikke blot har afsmitning fra de nye arbejdstidsregler, men også har forbindelse med skolereformens krav.

Der har været bekymringer over, om forældre til elever uden særlige behov ville protestere og eventuelt sætte deres børn i frie skoler, en risiko, der ikke kan undervurderes i de kommuner, der netop har en høj procentandel i frie skoler. Der var i 2013 ikke væsentlige tegn på, at dette var tilfældet. I 2014 er der en lille variation i elevtallet i folkeskoler og frie skoler, men det er mest udslag af, at der er etableret en eller nedlagt en fri skole. I 2014 er der 85 færre elever i frie skoler, end der var i 2013, mens der samtidig er et fald på 704 elever i folkeskolerne. I 2015 er der et generelt fald i elevtallet, men der er en stigning på 5,6 pct. i antallet af elever på frie skoler, hvad der helt overvejende skyldes oprettelsen af én ny fri skole i én kommune.

PPR spiller en væsentlig rolle i inklusionsbestræbelserne, og flere skolechefer og PPR-ledere udtrykte i 2013, at der syntes at være et klart behov for anderledes kompetencer i bemandingen end de traditionelt psykologiske. Man efterspurgte på skolerne personer, der havde en didaktisk vinkel i deres rådgivning. De mest yderligtgående eksempler var fra nogle store skoler, der hellere vil købe deres servicer selv end betale for 
dem gennem PPR - PPR koster i gennemsnit ca. 2.000 kr. årligt pr. elev. Det så ud til, at en del psykologer stadig havde deres professionsideal i fejlfinding og udredninger. PPR har generelt fra 2013 til 2014 gennemgået en stor udvikling, hvor kommuner er blevet inspireret af KL's pejlemærker for fremtidens PPR og har udviklet ydelseskataloger målrettet brugerne af PPR. PPR er i en del tilfælde gået bort fra en videreudvikling af deres ydelseskataloger, dette forklarer lederne med, at PPR-medarbejderne i alle 12 kommuner nu er placeret på skolerne, hvorfor de har fået en mere direkte kontakt til de enkelte lærere, samtidig med at de beskriver, at der er så varierende behov, at det ikke giver mening at have et ydelseskatalog.

En anden udfordring i 2013 vedrørte PPR's forvaltningsmæssige placering, hvor en fundering $i$ andet end skoleforvaltningen syntes at give vanskeligheder, fordi der er et forskelligt syn på, hvad den optimale opgaveløsning er, ligesom det kan udfordre samarbejdet mellem skolechef og PPR. I 2014 ses imidlertid en klar tendens til, at kommunerne arbejder på at udbygge det tværfaglige samarbejde i forvaltningerne. Dette er fortsat i 2015. Der har, især i den sidste del af perioden 2013-2015, været en stor udskiftning af ledere i forvaltningerne, hvilket har medført store ændringer i forvaltningernes organisering, ligesom det har givet brud i kontinuiteten i arbejdsprocesserne.

Visitationsprocesserne har fået mindre betydning ved overgang til, at skoler i høj grad selv skal finansiere specialtilbud, og det gav i 2013 af og til anledning til, at PPR følte sig marginaliseret i processen. I 2014 var det fælles for flere af PPR-enhederne, at de arbejdede på at etablere en helt fast struktur for, hvornår en elev kan indstilles til visitation. Dette skete for at sikre, at der arbejdes tilstrækkeligt med eleven i almenmiljøet. Dette er fortsat i 2015.

Der er i forbindelse med undersøgelsens start i 2013 defineret seks inklusionsindikatorer: Startår for inklusionsprocessen. Grad af fælles værdigrundlag på forvaltningsniveauet. Grad af kompetenceudvikling. Grad af økonomiske incitamenter. Kvalitet af samarbejdet mellem skoleforvaltning og PPR. Ændring i inklusionsprocenten fra 2010 til 2013. Det gjaldt om disse, at de først og fremmest skulle tjene som baseline for de næste to undersøgelsesrunder.

I 2014 og igen i 2015 anvendes de samme inklusionsindikatorer, dog går inklusionsprocenten nu fra 2010 til 2015. Der kan naturligvis ikke være ændringer i forhold til startår for inklusionsprocessen. De fem indikatorer anvendes i forbindelse med analyse af data fra skolebestyrelsesformænd, skoleledere og lærere i den følgende del af 2015rapporten. 


\section{Del 2. Data fra skoleledere, skolebesty- relsesformænd, lærere, elever og for- ældre}

Af Siddhartha Baviskar og Christopher de Montgomery

\section{Kvantitative resultater fra spørgeskemaunders $\varnothing$ gelser og DCUM's trivselsmåling blandt elever}

I denne rapport har vi indtil videre belyst omstillingsprocessen til øget inklusion i folkeskolen pr. marts 2015 ud fra et kommunalt perspektiv. Dette har vi gjort ved (1) at give et bredt portræt af omstillingsprocessen til øget inklusion i de 12 kommuner i undersøgelsen og (2) at foretage kvantitative analyser fra interviews med skolechefer og PPR-ledere i de pågældende kommuner. I forlængelse af dette kommunale perspektiv er formålet med denne anden del af rapporten at undersøge omstillingsprocessen til øget inklusion pr. marts $2015 \mathrm{ud}$ fra henholdsvis skolelederne, lærerne, bestyrelsesformændene, eleverne og forældrenes perspektiv. Afsnittet er struktureret efter følgende fem fokuspunkter for arbejdet med øget inklusion i folkeskolen:

1. Inklusionsfremmende styringsmodeller

2. Kompetencer

3. Opbakning til inklusion

4. Fastholdelse af elevernes trivsel

5. Supplerende undervisning.

For hvert af de fem fokuspunkter vil vi i det følgende præsentere de væsentligste resultater fra spørgeskemaundersøgelserne blandt skolelederne, lærerne og bestyrelsesformændene på skolerne i de 12 kommuner. Hvad angår det fjerde fokuspunkt - fastholde af elevernes trivsel - inddrager vi desuden både resultaterne fra (1) trivselsmålingen blandt eleverne i 2. og 8. klasse og (2) undersøgelsen af forældrenes opfattelse af deres børns trivsel i skolen. 
Der er foretaget to typer af statistiske analyser ved hvert fokuspunkt. For det første analyserer vi de relevante spørgeskemasvar over tid, idet vi sammenholder besvarelserne fra denne tredje og sidste indsamlingsrunde i foråret 2015 med resultaterne fra første indsamlingsrunde gennemført på samme tidspunkt to år tidligere. Ved at sammenholde disse resultater med resultaterne fra den tilsvarende analyse i sidste rapport fra marts 2014 giver kapitlet et indblik i udviklingstendenserne i omstillingsprocessen over de tre år. Resultaterne fra alle tre indsamlingsrunder er præsenteret i tabelmaterialet i Appendiks.

For det andet analyserer vi sammenhængen mellem spørgeskemasvarene inden for ovenstående fem fokuspunkter og de syv inklusionsindikatorer, som blev opstillet ved projektets begyndelse i 2013. De syv inklusionsindikatorer er:

1. Startår for inklusionsprocessen

2. Grad af fælles værdigrundlag på forvaltningsniveauet

3. Grad af kompetenceudvikling

4. Grad af økonomiske incitamenter

5. Kvalitet af samarbejde mellem skoleforvaltning og PPR

6. Ændring i inklusionsprocenten fra 2010 til 2013

7. Kommunernes socioøkonomiske indeks.

Inklusionsindikatorerne er i del 1 blevet beskrevet i forhold til hver af de 12 kommuner, der indgår i undersøgelsen. Kommunernes socioøkonomiske indeks pr. marts 2015 fremgår dog af figur B3.5 i Bilag 3. Kommunernes inklusionsprocent pr. marts 2015 fremgår af tabel B.3.2.

For begge typer af statistiske analyser er det værd at bemærke, at vi som følge af det relativt lave antal besvarelser i hver gruppe finder relativt få statistisk signifikante resultater. Dette forhold er særligt udtalt for analyser vedrørende skolelederne $(n=83)$ og bestyrelsesformændene $(n=77)$, idet vi - i forhold til lærerne $(n=686)$ - har væsentligt færre besvarelser for disse to respondentgrupper.

\section{Datamaterialet}

Det datamateriale, der ligger til grund for analyserne i denne anden del af rapporten, bygger hovedsagligt på spørgeskemabesvarelser fra skoleledere, skolebestyrelsesformænd og lærere i de 12 kommuner. 
Tabel 29. Antal udsendte spørgeskemaer, antal besvarelser og svarprocenten for henholdsvis skoleledere, skolebestyrelsesformænd og lærere.

\begin{tabular}{|l|c|c|c|}
\hline & $\begin{array}{c}\text { Antal udsendte } \\
\text { spørgeskemaer }\end{array}$ & Antal besvarelser & Svarprocent \\
\hline Skoleledere & 124 & 83 & 67 pct. \\
\hline Skolebestyrelsesformænd & 120 & 77 & 64 pct. \\
\hline Lærere & 1.886 & 686 & 36 pct. \\
\hline
\end{tabular}

Regeringen og kommunerne har fastsat en målsætning om, at elevernes trivsel skal fastholdes i takt med omstillingen til øget inklusion. For at belyse denne målsætning har vi foruden de tre spørgeskemaundersøgelser til lærere, ledere og bestyrelsesformænd foretaget en måling af elevernes trivsel i 2. og 8. klasserne på skolerne i de 12 udvalgte kommuner. Målingen er gennemført ved hjælp af "Termometeret", som er et værktøj til måling af elevers trivsel, der er udviklet og drevet af Dansk Center for Undervisningsmiljø (DCUM).

Endelig har vi, som et supplement til trivselsmålingen blandt eleverne, spurgt forældrene til eleverne i 2. og 8. klasse, hvordan de opfatter deres børns trivsel i skolen.

\section{Analyseresultater for de fem fokuspunkter:}

\section{Fokuspunkt 1: Inklusionsfremmende styringsmodeller (tabel B2.1-B2.29 i Appen- diks)}

Vedrørende de inklusionsfremmende styringsmodeller på skolerne har vi overordnet set spurgt ind til tre forskellige forhold, nemlig (1) incitamenterne til øget inklusion på skolerne, (2) samarbejdet mellem skolerne og PPR og (3) skoleledernes rolle i visitationsprocessen.

\section{Incitamenter til øget inklusion}

Hvad angår det første forhold - incitamenter til øget inklusion - angiver tre ud af fire skoleledere (74 pct.), at skolen har et økonomisk incitament til inklusion af elever på skolen. I modsætning hertil var det blot 62 pct. af skolelederne, som i første indsamlingsrunde i 2013 svarede, at der eksisterede sådanne økonomiske incitamenter på skolen, mens det var 80 pct. i anden runde. Men ændringen fra runde 1 er hverken i denne eller i sidste runde signifikant. Det er dog vigtigt at være opmærksom på, at vi - trods den relativt høje svarprocent blandt skolelederne i de 12 kommuner - opererer med et lavt antal observationer i analysen, hvilket gør det svært at finde statistisk signifikante forskelle 
mellem de to runder. ${ }^{2}$ Andelen af skoleledere (74 pct.), som vurderer, at der findes et økonomisk incitament til inklusion på skolerne stemmer nogenlunde overens med analyserne på kommuneniveau. Således oplyste $10 \mathrm{ud}$ af 12 skolechefer (dvs. 83 pct.), at der i kommunerne er etableret økonomiske incitamenter til at inkludere flere elever i den almindelige undervisning, jf. rapportens del 1. Forskellen mellem vurderingen blandt skoleledere og skolechefer er dog større i denne runde, end den var i 2. runde, hvor 80 pct. af skolelederne mente, at skolen have økonomiske incitamenter til inklusion.

Foruden spørgsmålet om økonomiske incitamenter til inklusion har vi også spurgt skolelederne om, i hvilket omfang de enkelte lærere på skolen har et incitament til at inkludere elever med særlige undervisningsbehov i den almindelige klasseundervisning. Her vurderer blot 7 pct. af skolelederne, at lærerne "i høj grad" har et incitament til at inkludere elever med særlige undervisningsbehov i klassen. Ingen skoleledere vurderer, at lærerne i "meget høj grad" har incitament til at inkludere elever med særlige undervisningsbehov i klassen. I 1. og 2. runde var den samlede andel for de to svarkategorier hhv. 11 og 13 pct. Så udviklingen har, som det fremgår af tabel B2.2 i Appendiks, bevæget sig i negativ retning. Forskellen er dog ikke statistisk signifikant.

I modsætning hertil viser analyserne af lærernes egen vurdering af deres incitament til inklusion, at incitamentet med statistisk sikkerhed er steget fra 1. til 3. indsamlingsrunde. Således svarer knapt hver fjerde lærer (23 pct.) i 3. runde, at de "i meget høj grad" eller "i høj grad" har et incitament til at inkludere elever med særlige undervisningsbehov i klassen, mens det blot var 16 pct. af lærerne, som angav dette i 1. runde. Selvom der er en tendens til, at lærerne i højere grad end før mener, at de har incitament til at inkludere børn med særlige undervisningsbehov, så er andelen af lærere, der "i mindre grad" eller "slet ikke" mener, at de har incitament til at inkludere elever med særlige undervisningsbehov, dog stadig større, nemlig 33 pct. i runde 3. På en skala fra 1 til 5 , hvor 5 angiver en meget høj grad af incitamenter og 1 angiver slet ingen incitamenter, er den gennemsnitlige besvarelse i runde 3 2,13 for skolelederne og 2,8 for lærerne. Med andre ord vurderer begge grupper i gennemsnit, at lærernes incitamenter befinder sig et sted mellem "i mindre grad" og "i nogen grad".

\section{Samarbejde mellem skoler og PPR}

Ud over incitamenterne til inklusion, herunder de økonomiske incitamenter, har vi også spurgt skolelederne og lærerne om, hvordan de vurderer deres samarbejde med PPR. Parallelt til 1. og 2. runde angiver mere end 85 pct. af skolelederne, at ledelsen på skolen holder faste møder med PPR. Desuden mener skolelederne helt generelt, at samarbejdet

\footnotetext{
2 Det samme gør sig gældende for analyserne vedrørende skolebestyrelsesformændene.
} 
med PPR fungerer godt. Det positive samarbejde gør sig både gældende med hensyn til (A) rådgivning og vejledning, (B) udredning af elever og (C) supervision. Andelen af positive besvarelser er højere end i 1. runde og lavere end i 2. runde. Forskellene er dog ikke statistisk signifikante.

I modsætning til skolelederne er lærernes vurdering af samarbejdet med PPR generelt mere lunken. Hvor skolelederne på en femtrinsskala fra 1 til 5, hvor 5 er "meget godt", vurderer skoleledelserne i snit samarbejdet på de forskellige områder omkring 44,4, mens lærerne i snit vurderer det til mellem 2,7 og 3,1, altså lige omkring middel. I forhold til første runde er der heller ingen statistisk signifikante forskelle i lærernes besvarelser.

\section{Skoleledernes rolle i visitationsprocessen}

Det tredje forhold, som vi har undersøgt ved de inklusionsfremmende styringsmodeller, er i hvilket omfang, skolelederne er involveret i visitationsprocessen, når der skal træffes afgørelse om placeringen af en elev fra skolelederens egen skole. I lighed med de forrige to runder rapporterer knapt 60 pct. af skolelederne, at de enten "i meget høj grad" eller "i høj grad" er involveret i visitationsprocessen. Andelen er lidt mindre end i de tidligere runder. Andelen af skoleledere, der "slet ikke" er involverede i visitationsprocessen, er vokset til knap 20 pct., hvilket er en stigning på en tredjedel sammenlignet med runde 1. Selvom der generelt tegner sig et billede af, at skolelederne i høj grad deltager i visitationsprocessen, er der således også ganske mange skoleledere (i alt 43 pct.), som "slet ikke", "i mindre grad" eller "i nogen grad" er involveret i denne proces. Forskellene mellem runderne er ikke statistisk signifikante, og der er ikke grund til at tro, at omstillingen til øget inklusion har ændret ved dette.

\section{Sammenhængen mellem inklusionsfremmende styringsmodeller og de syv inklusi- onsindikatorer}

\section{Skoleledere}

Vi har analyseret sammenhængen mellem skoleledernes svar på spørgsmålene om inklusionsfremmende styringsmodeller og de syv inklusionsindikatorer (se tabellerne B2.8-21 i Bilag 2 for en udtømmende oversigt over analyseresultaterne). Blandt resultaterne kan det fremhæves, at vi finder en statistisk sikker sammenhæng mellem startåret for inklusionsprocessen i kommunen og skoleledernes vurdering af de økonomiske incitamenter til inklusion på skolen. Her finder vi en tendens til, at en større andel af skolelederne mener, at et sådant økonomisk incitament eksisterer, hvis inklusionsprocessen blev påbegyndt i 2011 eller 2012 sammenlignet med 2013. 
Herudover finder vi - som i 2. runde - en tendens til en negativ sammenhæng mellem graden af fælles værdigrundlag på forvaltningsniveau og andelen af skoleledere, som mener at have et økonomisk incitament til inklusion på skolen. Med andre ord, skoleledere i kommuner med mellemhøj grad af fælles værdigrundlag mener i højere grad end skoleledere i kommuner med en høj grad af fælles værdigrundlag, at skolen har økonomiske incitamenter til inklusion af elever. Ingen kommuner har i 3. runde en lav grad af fælles værdigrundlag. Samtidig er skolelederne i kommuner med en mellemhøj grad af fælles værdigrundlag også signifikant mere involverede i visitationsprocessen. Dette kunne tyde på en mere direkte arbejdsgang mellem PPR og skolelederen, hvis samarbejdet ikke fungerer på højere niveau. Dette understøttes af, at skoleledere i kommuner, hvor der er en høj grad af samarbejde mellem skoleforvaltning og PPR, i mindre grad har faste møder med PPR på skolen sammenlignet med kommuner, hvor samarbejdet mellem skoleforvaltning og PPR er mellemhøjt.

Samtidig siger skolelederne i kommuner med lavere socioøkonomisk indeks i højere grad end skoleledere i kommuner med højt socioøkonomisk indeks, at de har faste møder med PPR på skolen, og at skolelederen er involveret i visitationsprocessen. Forskellene mellem kommuner kan således også skyldes strukturelle forhold ved kommunen snarere end værdier og graden af samarbejde i forvaltningen.

\section{Lærere}

Vi har også analyseret sammenhængen mellem lærernes svar og de syv inklusionsindikatorer (se tabel B2.22). Analyseresultaterne viser blandt andet, at lærere i kommuner, hvor inklusionsprocenten har ændret sig med over 2 procentpoint, vurderer samarbejdet med PPR lavere ift. både rådgivning og udredning end i kommuner med en lavere stigning i inklusionsprocenten. Modsat resultaterne i runde 2 er sammenhængen mellem lærernes oplevelse af kvaliteten af samarbejdet med PPR og de øvrige inklusionsindikatorer dog ikke så klar.

I de kommuner, hvor skolechefen i forvaltningen vurderer, at der i høj grad er et økonomisk incitament til inklusion, vurderer lærerne deres incitament til inklusion højere end i kommuner, hvor forvaltningen vurderer incitamentet som mellemhøjt, men lavere end i kommuner, hvor forvaltningens vurdering er lav. Dette tyder på, at økonomiske incitamenter, som de ser ud fra forvaltningens perspektiv, ikke sætter sig igennem for lærerne på en ensartet måde. 


\section{Fokuspunkt 2: Kompetenceudvikling (tabel B2.30-B2.91 i Appendiks)}

I dette afsnit undersøger vi, hvordan skolerne arbejder med kompetenceudvikling i forbindelse med omstillingen til øget inklusion. Først undersøger vi de aktiviteter, som skolerne har haft i forbindelse med arbejdet med inklusion. Herefter undersøger vi de ressourcer, som er tilgængelige for skolens lærere og pædagoger i forhold til arbejdet med inklusion.

\section{Aktiviteter}

Der er sket et markant fald i forhold til skolernes prioritering af kompetenceudviklingsaktiviteter med henblik på arbejdet med inklusion. Hvor 72 pct. af skolelederne i runde 1 og 61 pct. af skolelederne i runde 2 svarede, at der på deres skole er blevet afholdt en pædagogisk dag om inklusion, er tallet kun en fjerdedel (25 pct.) i runde 3. Andelen af skoleledere, der har haft lærere på kursus, er faldet fra 78 pct. i runde 1 til 54 pct. i runde 3 , mens andelen af skoleledere, der har taget initiativ til at arbejde med bestemte pædagogiske modeller eller værktøjer, er faldet fra 84,5 pct. til 54 pct. På trods af det begrænsede analyseudvalg er alle tallene statistisk signifikante. Dette bratte fald er ganske iøjefaldende. Det er ikke utænkeligt, at folkeskolereformen, der blev sat i værk på skolerne i august 2014, kan have optaget skolernes opmærksomhed, og at inklusionsarbejdet i den forbindelse har fået en lavere prioritet.

Dette billede bekræftes af lærerne, der også er blevet spurgt om hvilke konkrete aktiviteter, som de i dette skoleår har deltaget i vedrørende arbejdet med inklusion. Andelen af lærere, der har deltaget i en pædagogisk dag om inklusion, er faldet fra 34 pct. i runde 1 til 15 pct. i runde 3 . Andelen af lærere, der har deltaget i kurser om inklusion, er faldet fra 28 pct. i runde 1 til 13 pct. i runde 3. Andelen af lærere, der har deltaget i kurser om bestemte pædagogiske modeller, er faldet fra 35 pct. i runde 1 til 15 pct. i runde 3. Og andelen af lærere, der har gjort brug af informationsmateriale om inklusion, er faldet fra 21 pct. i runde 1 til 12 pct. i runde 3. Samtidig er andelen, der ikke har deltaget i nogen af de nævnte aktiviteter, fordoblet fra 22 pct. i runde 1 til 44 pct. i runde 3. Alle forskellene er statistisk højsignifikante. Den eneste aktivitet, hvor andelen af lærere, der har deltaget i den, er vokset, er at gøre brug af en inklusionsvejleder. Her er andelen steget statistisk signifikant fra 10 til 16 pct. Dette svarer til en stigning fra en ud af ti til omkring en ud af 6. Det drejer sig således stadig om en ganske lille gruppe lærere.

Andelen af lærere, der har deltaget i aktiviteterne, var allerede i udgangspunktet overraskende lav. Fx var det overraskende, at under en tredjedel af lærerne har deltaget i en pædagogisk dag om inklusion sidste år, da næsten to tredjedele af skolelederne rapporterede, at de havde holdt en pædagogisk dag på skolen. Som nævnt i sidste års rap- 
port kan en mulig forklaring på diskrepansen imellem skoleledernes og lærernes besvarelser være, at skolelederne og lærerne har forskellige opfattelser af, hvorvidt en pædagogisk dag har omhandlet inklusion eller ej. Men det kan også handle om, at lærernes deltagelse i de afholdte aktiviteter har været lav, således at selvom der fx blev holdt en pædagogisk dag på skolen, så var det kun et mindretal af lærerne, der deltog.

Ud over at spørge ind til de konkrete aktiviteter vedrørende inklusion har vi desuden spurgt lærerne, i hvilken grad de er blevet tilbudt kompetenceudvikling i forhold til arbejdet med inklusion. Her ligner resultaterne i 3. runde mere resultaterne i de tidligere runder, selvom der alligevel er sket et signifikant fald. På en skala fra 1 (læreren er "slet ikke" blevet tilbudt kompetenceudvikling) til 5 (læreren er "I meget høj grad" blevet tilbudt kompetenceudvikling) er gennemsnitsbesvarelsen faldet fra 2,1 til 1,9. Faldet er dog kun signifikant ved et signifikansniveau på 10 pct. Andelen, der "slet ikke" er blevet tilbudt kompetenceudvikling, er vokset fra 37 pct. til 43 pct. Det generelle billede er således, at lærerne (stadig) kun i meget begrænset omfang oplever at være blevet tilbudt kompetenceudvikling i forhold til arbejdet med inklusion.

Ligesom med spørgsmålene omkring lærernes deltagelse i aktiviteter i forbindelse med inklusion synes resultaterne med hensyn til spørgsmålet omkring lærernes kompetenceudvikling heller ikke at være i fuld overensstemmelse med skoleledernes angivelse af afholdte aktiviteter i forbindelse med inklusion. En mulig forklaring på den lave andel af lærere, som er blevet tilbudt kompetenceudvikling i forhold til arbejdet med inklusion, kunne være, at lærerne allerede besidder de nødvendige kompetencer til at håndtere arbejdet med inklusion. Det tyder andre resultater fra undersøgelsen imidlertid ikke på er tilfældet. Således er andelen af lærere, der "i meget høj grad" eller "i høj grad" føler sig fagligt rustet til at håndtere udfordringerne forbundet med inklusion, kun omkring 11 pct. Resultaterne med hensyn til dette spørgsmål ligner i vidt omfang resultaterne fra 1. runde, men sammenlagt er der faktisk en signifikant stigning i lærernes gennemsnitlige besvarelse på dette spørgsmål. Hvor gennemsnittet før var 2,48 på en skala fra 1 til 5, hvor 5 betyder, at de i meget høj grad føler sig fagligt rustede, og 1 betyder, at de slet ikke føler sig rustede, er gennemsnittet nu 2,59. Der er således en fremgang, om end gennemsnittet stadig befinder sig mellem kategorierne "i mindre grad" og "i nogen grad".

\section{Ressourcer}

Mens formålet med det foregående afsnit har været at belyse de aktiviteter, som skolerne i skoleåret 2014/15 har gennemført i forbindelse med arbejdet med inklusion, fokuserer vi i dette afsnit på de ressourcer, som er tilgængelige for skolens lærere og pædagoger i forhold til arbejdet med inklusion. Til at belyse dette spørgsmål har vi bedt skolelederne 
om at angive, hvorvidt en række ressourcer er tilgængelige for skolens lærere og pædagoger. Her svarer skolelederne på langt de fleste skoler, at de mener, at der er en række ressourcer tilgængelige. Det gælder bl.a. muligheden for rådgivning fra PPR, samarbejde med medarbejdere fra skolens specialcenter/ressourcecenter samt bistand fra en AKTvejleder på skolen. Der er imidlertid også enkelte ressourcer, såsom tilknytning af en lærerassistent og mulighed for rådgivning fra et andet videnscenter, som i et mere begrænset omfang er tilgængelige på skolerne. I forhold til de to foregående år er der flere ressourcer, der ifølge skolelederne i signifikant mindre grad er tilgængelige. Det er tilfældet med tilgængeligheden af en AKT-vejleder på skolen (før 81 pct., nu 64 pct.), muligheden for at sparre med en medarbejder fra skolens specialcenter/ressourcecenter (før 85 pct., nu 53 pct.), muligheden for rådgivning fra PPR (før 98 pct., nu 74 pct.), muligheden for rådgivning fra et andet videnscenter (før 28 pct., nu 10 pct.) samt den åbne kategori "andet" (før 10 pct., nu 2 pct.). Hvor der i 2. runde var signifikant flere skoleledere, der tilkendegav, at lærere og pædagoger havde adgang til en inklusionsvejleder på skolen, sammenlignet med 1. runde, så er forskellen mellem 1. og 3. runde ikke signifikant, om end det stadig er tilfældet på næsten to ud af fem skoler i 3. runde og kun en ud af fire skoler i 1. runde.

Dette billede af et generelt fald i tilgængeligheden af diverse ressourcer går igen i lærernes besvarelser. Der er signifikant færre lærere, der oplever at have adgang til en inklusionsvejleder på skolen (før 91 pct., nu 31 pct.), en AKT-vejleder på skolen (før 65 pct., nu 53 pct.), rådgivning fra specialskole (før 7 pct., nu 3 pct.) og informationsmateriale (før 10 pct., nu 7 pct.). Hvor det i de tidligere runder var langt størstedelen, der oplevede at have adgang til en inklusionsvejleder og en AKT-vejleder på skolen, er det nu et mindretal. Der er til gengæld også signifikant flere lærere, der oplever at have adgang til en medarbejder fra skolens specialcenter/ressourcecenter (før 19 pct., nu 32 pct.) og til rådgivning fra PPR (før 22 pct., nu 27 pct.). Tallene er stadig lavere end skoleledernes vurdering, i særdeleshed adgangen til rådgivning fra PPR, som nærmest alle skoleledere i de forrige runder, og tre ud af fire skoleledere i denne runde, vurderer, at lærerne har adgang til. Dette kunne tyde på, at det ikke er tydeligt for lærerne, hvordan de kan få adgang til en PPR-rådgiver på trods af, at ressourcen egentlig er tilgængelig, eller at lærerne og skolelederne vurderer forskelligt, om rådgivningen fra PPR er en ressource i forhold til arbejdet med inklusion. 


\section{Sammenhængen mellem kompetenceudvikling og de syv inklusionsindikatorer}

\section{Skoleledere}

75 pct. af de skoleledere, der har besvaret spørgeskemaet, siger, at de på skolen har en skriftlig strategi eller målbeskrivelse for skolens arbejde med inklusion. Det er lidt flere end i begge de foregående runder, om end forskellen ikke er signifikant. Andelen fordeler sig relativt ligeligt mellem undergrupperne for inklusionsindikatorerne, uden nogen signifikante forskelle. Der er altså ikke nogen sammenhæng mellem andelen af skoler, der har en skriftlig strategi og (1) startår for inklusionsprocessen, (2) graden af fælles værdigrundlag, (3) graden af kompetenceudvikling, (4) graden af økonomiske incitamenter, (5) kvaliteten af samarbejde mellem skoleforvaltningen og PPR, (6) ændring i inklusionsprocenten eller (7) kommunernes socioøkonomiske indeks. I runde 2 var der signifikant flere skoler, der havde en skriftlig strategi i kommuner med en lav grad af $ø$ konomiske incitamenter. I denne runde er der ingen signifikant forskel mellem de to grupper, men gennemsnittet er denne gang højere i kommuner med en høj grad af økonomiske incitamenter (75 pct.) end i kommuner med en lav grad af økonomiske incitamenter (67 pct.).

I forhold til aktiviteter er der ingen signifikante forskelle i forhold til (1) startåret for inklusionsprocessen, (2) graden af fælles værdigrundlag, (3) graden af kompetenceudvikling, (4) graden af økonomiske incitamenter, (5) kvaliteten af samarbejdet mellem skoleforvaltningen og PPR og (7) kommunernes socioøkonomiske indeks. I forhold til (6) ændringen i inklusionsprocenten i kommunen viser sammenligningerne dog signifikante forskelle mellem kommunerne. I kommuner, hvor ændringen i inklusionsprocenten er mindre end 1 pct., er andelen af skoler, der har taget initiativer til at arbejde med bestemte pædagogiske værktøjer, signifikant lavere $(20$ pct. overfor 64 pct. for gruppen af kommuner med en ændring i inklusionsprocent på 1-2 pct.). Andelen af kommunernes skoler, der har haft lærere på relevante kurser i forhold til inklusion, er noget lavere, 40 pct. overfor 64 pct., men denne forskel er ikke statistisk signifikant. I kommunerne med ændring i inklusionsprocent under 1 er der signifikant flere skoler, der har taget andre initiativer end de oplistede ( 40 pct. mod 12 pct.).

I forhold til tilgængeligheden af de forskellige former for ressourcer så er der flere skoler i kommuner, der påbegyndte inklusionsprocessen i 2012, der har en inklusionsvejleder på skolen, end blandt de kommuner, der påbegyndte processen både før og efter. Der er til gengæld signifikant flere skoler i kommuner, der påbegyndte inklusionsprocessen i 2013, hvor lærerne har adgang til rådgivning fra en specialskole eller fra et andet videnscenter. Samtidig er der signifikant færre skoler i netop de kommuner, der begyndte inklusionsprocessen sent, hvor lærerne har adgang til en lærerassistent. Dette går igen, når der kigges på, hvorvidt lærerne anvender ressourcerne (ifølge skolelederne). Ande- 
len af lærere, der anvender en lærerassistent, er signifikant lavere i kommuner, der påbegyndte inklusionsprocessen i 2013. Her er gennemsnittet 1, hvilket betyder, at alle skolelederne i disse kommuner siger, at lærerne slet ikke anvender en lærerassistent, hvilket er logisk, da alle de samme lærere siger, at lærerne ikke har adgang til en lærerassistent. For skolerne, der påbegyndte inklusionsprocessen tidligere, ligger gennemsnittet mellem "i mindre grad" og "i nogen grad".

Resultaterne af sammenligningerne med de øvrige inklusionsindikatorer forekommer noget usystematiske. I de kommuner, hvor der er en høj grad af fælles værdigrundlag på forvaltningsniveauet, er der signifikant flere skoler, hvor lærerne har adgang til en AKT-vejleder, men signifikant færre, der har adgang til en inklusionsvejleder. I kommuner, hvor der er en høj grad af kompetenceudvikling, er der ingen signifikante forskelle i tilgængeligheden af de forskellige former for ressourcer, men lærerne anvender, ifølge skolelederne, i mindre grad rådgivning fra specialskole og bestemte analysemodeller, men i højere grad rådgivning fra PPR. Da antallet af kommuner med en lav eller mellemhøj grad af økonomiske incitamenter er så lille, og antallet af skoler i disse kommuner i tredje runde ligeledes er lille, er der ikke nogen robuste forskelle at finde mellem kommunerne med forskellige grader af økonomiske incitamenter. I kommuner, hvor kvaliteten af samarbejde mellem PPR og skoleforvaltningen er højt, er inklusionsvejledere mindre tilgængelige og mindre brugte på skolerne. Interessant nok er der ingen signifikant forskel i forhold til tilgængeligheden og anvendelsen af rådgivning fra PPR. Dette fund er parallelt med den tendens, der blev fundet i sidste runde.

I kommuner, hvor ændringen i inklusionsprocent er over to, er tilgængeligheden af både inklusionsvejledere på skolerne og lærerassistenter mindre. Endelig er tilgængeligheden af lærerassistenter også mindre på skoler i kommuner med et socioøkonomisk indeks på over 1,1. Dette fund er parallelt med analysen i sidste runde og peger på, at skoler, der kan tænkes at have et større behov for lærerassistenter, da andelen af udsatte børn og kommunens socioøkonomiske profil må formodes at hænge sammen, har mindre adgang til ordningen. Dette er måske ikke overraskende, da ordningen i sammenligning med de øvrige ressourcer må være relativt dyr, men det kan pege på en problematisk tendens.

\section{Lærere}

Parallelt med analyserne for skolelederne finder vi også med hensyn til lærerne en række interessante sammenhænge mellem spørgsmålene vedrørende kompetenceudvikling og de syv inklusionsindikatorer. Således finder vi, parallelt med analysen i runde 2, en tendens til, at en senere kommunal start på inklusionsprocessen hænger sammen med en lavere grad af anvendelse af både inklusions- og AKT-vejledere. Lærerne i kommuner, 
der har påbegyndt inklusionsprocessen i 2013, har, på trods af at andelen generelt er blevet halveret, stadig i signifikant højere grad deltaget i pædagogiske dage om inklusion, og ligesom i de øvrige runder benytter signifikant flere sig af LP-modellen. Samtlige grupper bruger dog LP-modellen mindre år for år, så hvis den trend fortsætter, så vil forskellen mellem kommuner gradvist forsvinde, da lærerne ikke holder fast i metoden i mere end et par år. Omvendt kunne det tænkes, at det generelle fald i anvendelsen af samtlige af de oplistede pædagogiske værktøjer hang sammen med folkeskolereformen, hvis implementering har givet lærerne et andet sæt af udfordringer. Det er ikke utænkeligt, at lærerne igen vil anvende de forskellige pædagogiske værktøjer, når reformens elementer ikke længere er nye for dem.

I kommuner, hvor graden af fælles værdigrundlag i skoleforvaltningen er høj, anvender lærerne i mindre grad inklusionsvejledere og i signifikant højere grad AKTvejledere. Dermed er lærernes svar parallelle med skoleledernes svar.

Imod forventning rapporterer signifikant færre lærere i kommuner, der ud fra skolechefernes oplysning har haft en høj grad af kompetenceudvikling, at de er blevet tilbudt kompetenceudvikling i forhold til arbejdet med inklusion. Der er også færre lærere på skolerne i disse kommuner, der har deltaget i en pædagogisk dag om inklusion og i kurser om forskellige pædagogiske modeller, og som anvender fx LP-modellen. Til gengæld anvender de i højere grad AKT-vejledere på skolen og oplever i højere grad at have adgang til inklusionsvejledere på skolen, og medarbejdere fra skolens specialcenter/ressourcecenter. Tendensen er altså, at lærerne på skolerne i kommuner med en høj grad af kompetenceudvikling i mindre grad deltager i kurser og særlige aktiviteter om inklusion, men i højere grad har adgang til sparring og støtte på skolerne.

Ligesom fra skoleledernes perspektiv er der heller ikke fra lærernes perspektiv nogen forskel på anvendelsen af PPR's rådgivning mellem kommunerne afhængigt af kvaliteten af samarbejde mellem skoleforvaltningerne og PPR. I de kommuner, der har en ændring i inklusionsprocenten på over 2 pct., rapporterer lærerne, at de i mindre grad anvender inklusionsvejledere på skolen, men i højere grad anvender vejledning fra PPR og andre videnscentre.

Endelig finder vi, at lærerne i kommuner med relativt højt ressourceforbrug pr. elev i større omfang er blevet tilbudt kompetenceudvikling i forhold til arbejdet med inklusion og i højere grad anvender bestemte analysemodeller, lærerassistenter og medarbejdere fra specialklasser. De har også i højere grad deltaget i kurser om inklusion og i pædagogiske dage. Til gengæld har de i mindre grad adgang til en AKT-vejleder på skolen og en medarbejder fra skolens specialcenter/ressourcecenter. Samlet set giver lærernes besvarelser altså et lidt anderledes billede end skoleledernes besvarelser. 


\section{Fokuspunkt 3: Opbakning til inklusion (tabel B2.92-B2.140 i Appendiks)}

I dette afsnit undersøger vi først, i hvor høj grad der er opbakning til målsætningerne om øget inklusion blandt skolelederne, lærerne og bestyrelsesformændene på skolerne. Herefter undersøger vi de samme personers kendskab til målsætningerne om øget inklusion.

\section{Opbakning til inklusion}

Ligesom i de øvrige runder er der generelt langt større opbakning blandt skolelederne end blandt lærerne til inklusionsmålsætningen om at øge andelen af elever med særlige behov i den almindelige undervisning fra 94,4 pct. til 96,0 pct. Mens to ud af tre skoleledere (66 pct.) erklærer sig enten "enig" eller "meget enig" i inklusionsmålsætningen, er det blot 15 pct. af lærerne, som er "enig" eller "meget enig" i den samme målsætning. Tilsvarende er andelen af skoleledere, der er uenige i målsætningen om at øge andelen af elever i den almindelige undervisning, kun lige knapt 10 pct., mens hele 65 pct. af lærerne erklærer sig decideret "uenig" eller "meget uenig" i målsætningen. I denne forbindelse er det værd at bemærke, at lærernes gennemsnitlige opbakning til inklusion med statistisk sikkerhed faldt fra 1. til 2. runde, men at faldet mellem 1. og 3. runde er mindre og kun signifikant ved et signifikansniveau på 10 pct.

Foruden skolelederne og lærernes egen opbakning til målsætningen om øget inklusion har vi desuden bedt skolelederne om at vurdere opbakningen til øget inklusion blandt (A) skolens lærere og pædagoger, (B) forældre til børn med særlige behov og (C) forældre til børn uden særlige behov. For alle tre grupper vurderer over halvdelen af skolelederne, at der kun "i nogen grad", "i mindre grad" eller "slet ikke" er opbakning til øget inklusion, 65 pct., 53 pct. og 87 pct. respektive. Der er således væsentligt flere skoleledere, som vurderer, at der "i høj grad" eller "i meget høj grad" er opbakning blandt forældrene til børn med særlige behov (47 pct.) end blandt forældrene til børn uden særlige behov (13 pct.). Skoleledernes vurdering af skolens lærere og pædagogers opbakning er noget højere end lærernes besvarelse af, om de er enige i målsætningen, med gennemsnitlige besvarelser på 3,26 over for 2,12 på en femtrinsskala, hvor 5 er "meget enig" i målsætningen. Forskellen kan rumme et element af, at skolelederne overvurderer lærernes opbakning, men den kan også være funderet i, at lærerne, på trods af at de ikke er enige i målsætningen, alligevel bakker op om den i det daglige arbejde. Da der ikke med statistisk sikkerhed er forskel på skoleledernes besvarelser i de tre indsamlingsrunder, kan analysen ikke spore nogen udvikling i skoleledernes vurdering af opbakningen bland de tre grupper.

Parallelt med skolelederne har vi bedt skolebestyrelsesformændene om at vurdere opbakningen til øget inklusion fra de samme tre grupper. Generelt stemmer bestyrelses- 
formændenes vurderinger ganske godt overens med skoleledernes. Bestyrelsesformændene vurderer, at 60 pct., 56 pct. og 80 pct. "i nogen grad", "i mindre grad" eller "slet ikke" bakker op om øget inklusion blandt henholdsvis skolens lærere og pædagoger, forældre til børn med særlige behov og forældre til børn uden særlige behov. Heller ikke bestyrelsesformændenes besvarelser har ændret sig signifikant imellem runderne.

Lærernes vurdering af opbakningen gentager billedet af, at forældrene kun i begrænset omfang bakker op om målsætningen, mens ledelsen i vid udstrækning bakker op om den. Lærernes vurdering af forældrenes opbakning er blevet en anelse mere positiv mellem 1. og 3 . runde.

\section{Kendskab til inklusion}

I forlængelse af undersøgelsen af opbakningen til øget inklusion har vi også undersøgt (1) skoleledernes vurdering af lærernes kendskab til inklusionsmålsætningen og (2) bestyrelsesformændenes vurdering af forældrenes kendskab til inklusionsmålsætningen. Ligesom i de øvrige runder vurderer langt størstedelen af skolelederne (85 pct.), at lærerne "i meget høj grad", "i høj grad" eller "i nogen grad" har kendskab til inklusionsmålsætningen (mod 90 pct. i 1. runde). Hvad angår bestyrelsesformændene vurderer over halvdelen (54 pct.), at forældrene "i nogen grad" har kendskab til målsætningen om øget inklusion. Gennemsnittet er vokset statistisk signifikant fra 2,65 på en femtrinsskala i runde 1 til 3,05 i runde 3 (hvilket vil sige lige over midterkategorien "i nogen grad").

\section{Sammenhængen mellem opbakning til inklusion og de syv inklusionsindikatorer}

\section{Skoleledere og bestyrelsesformænd}

Med hensyn til skolelederne viser analyserne bl.a., at lederne både finder strategien i forhold til (1) samarbejdet mellem PPR og skolen og (2) tilrettelæggelsen af inkluderende læringsmiljøer mindre hensigtsmæssig, når graden af fælles værdigrundlag på forvaltningsniveau er høj, og når kvaliteten af samarbejdet mellem skoleforvaltning og PPR ligger på et højt niveau. Derudover oplever skoler i kommuner, der har et lavere socioøkonomisk indeks, i højere grad, at der er en strategi for øget inklusion og tilrettelæggelse af inkluderende læringsmiljøer. Hermed tyder det ifølge skolelederne på, at der er en sammenhæng mellem kommunernes socioøkonomiske forhold og tilstedeværelsen af strategier for inklusion, således at de socioøkonomisk bedst stillede kommuner i højere grad har udviklet strategier for inklusion.

Også bestyrelsesformændenes besvarelser peger på, at der er en forskel mellem de bedre bemidlede kommuner og de mindre bemidlede. Således vurderer bestyrelsesfor- 
mændene opbakningen til inklusion blandt forældrene i de socioøkonomisk mindre godt stillede kommuner lavere end i de bedre bemidlede kommuner.

\section{Lærere}

Hvad angår lærerne finder vi på baggrund af sammenhængsanalyserne ikke mange klare tendenser mellem deres opbakning til inklusion og de syv inklusionsindikatorer. Dog viser analyserne som i sidste runde, at forældrenes kendskab til målsætningen om øget inklusion ifølge lærerne er lavere i de socialøkonomisk dårligst stillede kommuner.

\section{Fokuspunkt 4: Fastholdelse af elevernes trivsel (tabel B2.141-B2.156 i Appendiks)}

Som bekendt er en af målsætningerne hos regeringen og kommunerne, at elevernes trivsel skal fastholdes i takt med omstillingen til øget inklusion. I denne forbindelse undersøger vi i dette afsnit, (1) hvilke trivselsmæssige indsatser skolerne har foretaget, og (2) i hvilket omfang bestyrelsesformændene er tilfredse med skolernes arbejde med elevernes trivsel, samt (3) i hvilket omfang eleverne i 2. og 8. klasse trives i skolen. Til at undersøge 2.- og 8.-klasse-elevernes trivsel inddrager vi både resultaterne fra trivselsmålingen blandt eleverne i 2. og 8. klasse og undersøgelsen af forældrenes opfattelse af deres børns trivsel i skolen.

\section{Trivselsmæssige indsatser på skolerne}

Skolelederne har angivet, hvorvidt skolen har foretaget en række indsatser eller aktiviteter i forbindelse med omstillingen til øget inklusion. I forhold til de forrige runder er tendensen, at skolen har iværksat færre initiativer rettet mod elevernes trivsel end tidligere. Hvor langt de fleste skoler afholdt klassemøder om elevernes trivsel i 1. og 2. runde (over 80 pct.), er tallet faldet til 57 pct. Hvor næsten alle skoler fastsatte klasseregler og/eller skoleregler for elevernes opførsel og samvær i 1. og 2. runde (mellem 84 og 93 pct.), er andelen i 3. runde 59 pct. Hvor ca. to ud af tre skoler i 1. og 2. runde havde venskabsordninger mellem forskellige klasser på skolen, er andelen kun lidt over to ud af fem i 3. runde. Og hvor omkring to ud af tre skoler holdt en trivselsdag for eleverne i foregående runder, er andelen i denne runde én ud af tre. Flere af aktiviteterne foregår stadig på flere end halvdelen af skolerne, men faldet er betragteligt, særligt med det in mente at der ingen signifikante forskelle var mellem skoleledernes besvarelser i 1 . og 2 . runde. 


\section{Skolebestyrelsens tilfredshed med skolens arbejde med elevernes trivsel}

I forlængelse af skoleledernes angivelse af indsatser og aktiviteter for elevernes trivsel har vi desuden spurgt bestyrelsesformændene, hvor tilfredse de alt i alt er med skolens arbejde med elevernes trivsel. Lidt færre bestyrelsesformænd erklærer sig i 3. runde "tilfreds" eller "meget tilfreds" med skolens arbejde med elevernes trivsel, men andelen er stadig lige knapt fire ud af fem. Der er således stadig stor opbakning fra skolebestyrelserne til den måde, som skolerne arbejder med elevernes trivsel på.

\section{Elevernes trivsel på skolerne}

Foruden skoleledernes trivselsindsatser og bestyrelsesformændenes holdning til skolens arbejde med elevernes trivsel har vi for det tredje spurgt direkte ind til, hvordan eleverne i 2. og 8. klasse trives på skolen. Af besvarelserne fremgår det, at langt de fleste elever i 2. klasse er glade for at gå i skole i almindelighed (72 pct.) og for deres klasse i særdeleshed (76 pct.). Herudover angiver mere end syv ud af 10 elever (72 pct.), at de har "mange" venner i klassen, ligesom mere end tre ud af fire elever (76 pct.) mener, at de "for det meste" har nogen at lege med i frikvartererne. Eleverne i 2. klasse er desuden generelt meget glade for deres lærere. Således angiver 81 pct. af eleverne, at de er glade for "alle eller de fleste" af deres lærere. Ud fra de fleste spørgsmål tegner der sig således, ligesom i de foregående runder, et billede af, at eleverne i 2. klasse generelt trives godt i skolen. Dog er gennemsnitsbesvarelsen på spørgsmålet om, hvorvidt eleverne er glade for deres klasse, faldet en anelse (omend signifikant) fra 1,80 til 1,74 (på en skala fra 0 til 2, hvor 2 er "ja").

Ligesom i de foregående runder mener over halvdelen af eleverne, at de kun "nogle gange" er gode ved hinanden i klassen (56 pct.). Derudover angiver knapt en fjerdedel (23 pct.) af eleverne, at de kun "nogle gange" har nogen at lege med i frikvartererne. Mens disse andele er stabile på tværs af runderne, så er andelene af elever, der svarer, at de blot har det "nogenlunde" for tiden eller decideret "dårligt", 30 pct., hvilket er signifikant flere end i de foregående runder.

Sammenligner vi med 8.-klasse-elevernes besvarelser genfinder vi den trend, der blev identificeret i forrige rapport, nemlig at eleverne i 8 . klasse generelt er mere glade for at gå i skole (78 pct.) og mere glade for deres klasse (85) end eleverne i 2. klasse. 8.klasse-eleverne behandler i højere grad hinanden godt i klassen (84 pct.). Tilsvarende har hele 95 pct. af eleverne i 8. klasse også "altid" eller "for det meste" nogen at være sammen med i frikvartererne. Omvendt er der dog lidt færre elever i 8. end i 2. klasse, som er glade for "alle" eller "de fleste" af deres lærere (70 pct. imod 81 pct. af 2.-klasseeleverne). Disse forskelle kan dog skyldes, at eleverne i anden klasse blev spurgt på en tretrinsskala ("ja"/"ja, altid", "nogle gange", "nej"/"nej, aldrig"), mens eleverne i 8. klas- 
se blev spurgt på en femtrinsskala ("ja, altid", "ja, for det meste", "nogle gange", "nej, ikke så tit", "nej, aldrig").

Generelt har 8. klassernes trivselsniveau ikke ændret sig det store siden runde 1, om end deres gennemsnit på spørgsmålet, om de er glade for at gå i skole, er faldet en anelse (men signifikant), fra 3,99 til 3,93 (på en femtrinsskala fra 1 til 5, hvor 5 er "ja, altid"). Omvendt er 8.-klasse-elevernes fravær også faldet fra 1. til 3. runde.

Som et supplement til trivselsmålingen blandt eleverne i 2. og 8. klasse har vi desuden undersøgt, hvordan elevernes forældre opfatter deres børns trivsel. Her viser analyserne helt generelt, at forældrene og elevernes svar på trivselsspørgsmålene i høj grad ligner hinanden. Forældrenes opfattelse af børnenes trivsel har ikke ændret sig nævneværdigt fra 1. til 3. runde.

\section{Sammenhængen mellem fastholdelse af elevernes trivsel og de syv inklusionsindi- katorer}

\section{Skolelederne}

Generelt finder vi kun få statistisk signifikante resultater med hensyn til sammenhængen mellem inklusionsindikatorerne og skoleledernes svar på, hvilke trivselsmæssige indsatser skolerne har foretaget. Dog viser analyserne, at der afholdes mere systematisk undervisning i sociale kompetencer på skoler i kommuner, der påbegyndte inklusionsprocessen i 2013, som har en høj kvalitet i samarbejdet mellem skoleforvaltningen og PPR, som har en høj grad af fælles værdigrundlag på forvaltningsniveauet, og som har en høj værdi på det socioøkonomiske indeks. I forhold til samarbejde med en trivselskonsulent er der en tendens til, at skolerne i kommuner med en lavere kvalitet i samarbejdet med PPR og kommuner med en lavere grad af fælles værdier på forvaltningsniveauet $\mathrm{i}$ højere grad samarbejder med en trivselskonsulent. Tallet svarer til fundet fra sidste runde, men er fortsat ganske lavt, kun omkring 13 pct. for begge grupper af kommuner.

\section{Lærerne}

Lærernes vurdering af, hvordan eleverne trives socialt, er blevet en anelse bedre mellem 1. og 3. runde (fra at 88 pct. trives godt til 90 pct.). Der er nogen variation i, hvilke kommuner denne forbedring drejer sig om. Andelen af elever, der ikke trives godt, er mindre i kommuner, der påbegyndte inklusionsprocessen i 2012, hvor det fælles værdigrundlag er højt, hvor graden af kompetenceudvikling er høj, hvor ændringen i inklusionsprocenten er lille, og hvor det socioøkonomiske indeks er lavt.

I forhold til elevernes faglige trivsel er der ingen signifikant forskel mellem runderne, men andelen, der trives dårligt, er mindre i kommuner, der påbegyndte inklusi- 
onsprocessen tidligere, som har en høj grad af fælles værdigrundlag, som har en høj grad af kompetenceudvikling, og som har et lavere socioøkonomisk indeks.

\section{Elever og forældre}

På grund af den relativt lave svarprocent, i særdeleshed for nogle kommuners vedkommende, er der ikke basis for at foretage en analyse af sammenhængen mellem de syv inklusionsindikatorer og henholdsvis eleverne og forældrenes angivelse af elevernes trivsel.

\section{Fokuspunkt 5: Supplerende undervisning (tabel B2.157-B2.162 i Appendiks)}

Ifølge folkeskolelovens § 3a skal børn, der har brug for støtte, og som ikke alene kan understøttes ved brug af undervisningsdifferentiering og holddannelse, tilbydes supplerende undervisning eller anden faglig støtte i henhold til § 5, stk. 5, hvor det hedder: "Der gives i fornødent omfang supplerende undervisning eller anden faglig støtte til elever, der har skiftet skole, eller som har været uden undervisning i længere tid. Der skal i fornødent omfang gives supplerende undervisning eller anden faglig støtte til elever, som af anden grund har behov for støtte".

I dette femte og sidste afsnit belyser vi en række forhold ved den supplerende undervisning på skolerne. Til dette formål undersøger vi først, hvordan skolerne tilrettelægger den supplerende undervisning. Herefter ser vi på, hvor mange elever der modtager supplerende undervisning i dette skoleår. Endelig undersøger vi, hvor mange elever som i dette skoleår er blevet inkluderet frem for at blive henvist til segregerede foranstaltninger.

\section{Tilrettelæggelsen af den supplerende undervisning}

Hvad angår tilrettelæggelsen af den supplerende undervisning viser besvarelserne fra skolelederne, at en tredjedel (34 pct.) af den supplerende undervisning i snit er tilrettelagt som tolærertimer. Herudover tilrettelægges 12 pct. af den supplerende undervisning med lærerassistenter, og en tredjedel (29 pct.) er tilrettelagt som et ressourcecenter uden for den almindelige undervisning. En fjerdedel (25 pct.) af den supplerende undervisning er i snit tilrettelagt på anden måde. I forhold til 1. runde er forskellene ikke statistisk signifikante, men hvor ressourcecentrets andel i runde 2 var signifikant lavere, er andelen nu tilbage omkring de 30 pct. Der er relativt få besvarelser på spørgsmålene, $46 \mathrm{i}$ runde 1 og 45 i runde 3 , hvorfor små forskelle, om end reelle, ikke vil fremstå som signifikante. 


\section{Antal modtagere af supplerende undervisning}

I forlængelse af spørgsmålet om, hvordan den supplerende undervisning tilrettelægges, har vi også spurgt skolelederne om, hvor mange der modtager supplerende undervisning. Her rapporterede skolelederne i runde 1, at der i gennemsnit var 23 elever, som modtog supplerende undervisning i skoleåret 2012/13 og 24 elever i skoleåret 2013/2014. I skoleåret 2014/2015 - denne runde - er tallet 25. Den gennemsnitlige afstand til gennemsnittet er dog steget i runde 3 (fra 22 elever til 32 elever), hvilket indikerer, at der særligt er nogle skoler med flere elever, der modtager supplerende undervisning i skoleåret 2014/2015. Der er altså stadig en stor spredning i antallet af elever på skolerne, der modtager supplerende undervisning, hvor nogle skoler slet ikke har nogen elever, og andre har rigtig mange elever.

Skolelederne er endvidere blevet spurgt om antallet af elever, som i sidste skoleår fik specialundervisning i tilknytning til den almindelige undervisning, men som i dette skoleår i stedet får supplerende undervisning. Denne andel er faldet til ca. det halve fra 15 pct. i runde 1 , til 8 pct. i runde 3.

\section{Antal inkluderede elever}

Endelig har vi bedt skolelederne om at angive, hvor mange elever der i dette skoleår er blevet inkluderet ved $i k k e$ at blive henvist til segregerede foranstaltninger. Her vurderer over halvdelen af skolelederne (59 pct.), at skolen har inkluderet imellem en og fem elever i dette skoleår. Derudover angiver 31 pct. af lederne, at mere end fem elever er blevet inkluderet frem for at blive henvist til segregerede foranstaltninger. Blot 10 pct. af skolelederne har svaret, at der ikke er blevet inkluderet nogen elever i dette skoleår, hvilket er dobbelt så mange som året før, men stadig lidt lavere end i runde 1. Ingen af forskellene er dog signifikante. Det er væsentligt her at påpege, at det er skoleledernes egne vurderinger, der ligger til grund for tallene. Det er interessant at bemærke, at skolelederne oplever, at de inkluderer væsentlige flere elever end de 0,6 og 0,5 pct., som ifølge kommunernes oplysninger, jfr. Tabel 13, er blevet inkluderet fra årene 2013 til 2014 og fra 2014 til 2015. 0,5 pct. svarer til en inkluderet elev ekstra pr. 200 elever.

\section{Sammenhængen mellem supplerende undervisning og de syv inklusionsindikatorer}

På baggrund af analyserne finder vi generelt ikke nogen sammenhænge mellem skolelederne eller lærernes besvarelser vedrørende den supplerende undervisning og de syv inklusionsindikatorer. 


\section{Sammenfatning af kvantitative svar fra: Skoleledere, skolebestyrel- sesformænd, lærere, elever og forældre}

I det følgende opsummeres de væsentligste resultater fra analyserne i rapportens del 2. Sammenfatningen bør læses med øje for, at analyserne beskriver tendenser til sammenhænge snarere end robuste sammenhænge og årsag-virkningsforhold.

Andelen af skoleledere, som vurderer, at der findes økonomiske incitamenter til inklusion på skolerne er høj og stemmer ligesom i sidste runde overens med analyserne på kommuneniveau. Ligesom i 1. og 2. runde vurderer kun en meget lille andel af skolelederne, at lærerne har et incitament til at inkludere elever med særlige undervisningsbehov i klassen. Der er mærkbart flere lærere, der mener, at de har et incitament til inklusion, men selv om andelen i tillæg dertil også er steget fra 1. runde, er det stadig kun en lille gruppe, der mener det.

Skolelederne mener generelt, at samarbejdet med PPR fungerer godt, og besvarelserne har ikke ændret sig signifikant mellem 1. og 3. runde. Lærerne deler dog ikke denne positive opfattelse og vurderer samarbejdet lidt under middel, hvilket ikke er signifikant forskelligt fra runde 1.

Der er sket et markant fald i forhold til skoleledernes arbejde med at ruste deres lærere til at håndtere arbejdet og udfordringerne i forbindelse med inklusion. Kun et mindretal af skolelederne angiver, at der i dette skoleår er afholdt en pædagogisk dag om inklusion, og kun omkring halvdelen har haft en eller flere lærere på relevante kurser. Dette billede bekræftes af lærerne, hvor antallet af lærere, der har deltaget i kompetenceudviklingsaktiviteter er faldet signifikant siden 1. runde. Over halvdelen af lærerne føler sig ikke fagligt rustet til at håndtere de udfordringer, der er forbundet med inklusion, om end andelen af lærere, der føler sig rustede, er vokset en anelse mellem 1. og 3. runde.

Også i tilgængeligheden af diverse ressourcer for lærerne i deres arbejde med inklusion sporer analysen et signifikant fald, både set fra skoleledernes perspektiv og fra lærernes. Det er stadig flertallet af skolelederne, der tilkendegiver, at en række ressourcer til inklusion er tilgængelige bl.a. muligheden for rådgivning fra PPR, samarbejde med skolens specialcenter/ressourcecenter samt bistand fra AKT-vejlederen på skolen. Men andelen er faldet markant. Denne tendens bekræftes af lærerne, der også generelt svarer mere negativt i forhold til tilgængeligheden af de forskellige ressourcer. Hvor det i tidligere runder var størstedelen af lærerne, der havde adgang til en inklusionsvejleder på skolen, er tallet under en tredjedel i denne runde.

Ligesom i 1. runde er der generelt langt større opbakning blandt skolelederne end blandt lærerne til inklusionsmålsætningen om at øge andelen af elever med særlige be- 
hov i den almindelige undervisning fra 94,4 pct. til 96,0 pct. Lærernes gennemsnitlige opbakning til inklusion er dog ikke faldet signifikant siden 1. runde.

Som i de tidligere runder vurderer størstedelen af skolelederne, at der er lav opbakning til øget inklusion blandt skolens lærere og pædagoger, forældre til børn med særlige behov og forældre til børn uden særlige behov. Af de to forældregrupper er opbakningen dog markant højere blandt forældre til børn med særlige behov.

Langt størstedelen af skolelederne vurderer, at lærerne har kendskab til inklusionsmålsætningen. Forældrenes kendskab til inklusionsmålsætningen er efter bestyrelsesformændenes vurdering markant lavere, men er steget siden 1 . runde.

Lidt over halvdelen af skolerne har afholdt en række aktiviteter og igangsat tiltag rettet mod fastholdelse af elevernes trivsel, hvilket er noget færre end i tidligere runder. Fra forældrenes øverste repræsentanter (bestyrelsesformændene) synes der dog fortsat at være stor opbakning til den måde, som skolerne arbejder med elevernes trivsel på. Generelt tyder analyserne på, at forældrene og elevernes svar på trivselsspørgsmålene i høj grad ligner hinanden. I elevernes egen vurdering trives eleverne i 2 . klasse generelt godt i skolen, og eleverne i 8 . klasse trives endda endnu bedre. Generelt ligner elevernes besvarelser hinanden på tværs af spørgsmålene i 1. og 3. runde, om end der er sket en stigning i antallet af 2.-klasse-elever, der blot har det nogenlunde eller dårligt for tiden, og et lille fald i andelen af 8.-klasse-elever, der er glade for at gå i skole.

Hvad angår tilrettelæggelsen af den supplerende undervisning, viser besvarelserne fra skolelederne, at en tredjedel (34 pct.) af den supplerende undervisning er tilrettelagt som tolærertimer. Herudover tilrettelægges 12 pct. af den supplerende undervisning med lærerassistenter. Andelene er ikke signifikant forskellige fra 1. runde.

Der er i gennemsnit 23 elever på hver skole, som modtager supplerende undervisning i skoleåret 2014/15. Da den gennemsnitlige skolestørrelse i de 12 kommuner i 2014 var 428 elever, svarer det i gennemsnit til 5,4 pct. af eleverne på hver skole. I 2011 - det sidste målepunkt før lovændringen i 2012 - var gennemsnittet nationalt på 6,6 pct. Antallet har ikke ændret sig signifikant siden 1 . runde, men spredningen er vokset med en gennemsnitlig afstand til gennemsnittet på 32 elever. Gennemsnittet dækker således over en stor spredning mellem skolerne med hensyn til antallet af elever, der modtager supplerende undervisning. Lidt under en tredjedel af skolelederne vurderer, at mere end fem elever er blevet inkluderet frem for at blive henvist til segregerede foranstaltninger, mens lidt færre end to tredjedele sætter antallet til mellem en og fem. 


\section{Sammenhængen mellem inklusionsindikatorerne og de fem fokuspunkter}

Det er svært at sammenfatte analysens fund i en sammenhængende fortolkning. Generelt finder vi kun få statistisk signifikante sammenhænge mellem inklusionsindikatorerne og besvarelserne i forhold til de fem fokuspunkter. Mens nogle resultater kan synes meningsfulde, er mange af dem vanskelige at fortolke. I det følgende opsummeres de resultater, der synes mest meningsfulde.

Vi finder en tendens til, at en større andel af skolelederne mener, at et økonomisk incitament til inklusion på skolen eksisterer, jo tidligere kommunen er startet på inklusionsprocessen. Derudover er inklusionsvejledere mere tilgængelige på skoler, der begyndte inklusionsprocessen tidligt. Blandt lærerne i kommuner, der påbegyndte inklusionsprocessen senere, er andelen, der anvender inklusions- og AKT-vejledere på skolen mindre. Dette peger på, at skolerne i de kommuner, der kom tidligere i gang, på nogle områder er kommet længere i arbejdet.

Vi finder en tendens til, at skolelederne er mere involverede $\mathrm{i}$ visitationsprocessen $\mathrm{i}$ forbindelse med afgørelsen om placering af en elev, når der på forvaltningsniveau er en lav grad af fælles værdigrundlag. Derudover rapporterer skolelederne i højere grad, at der er faste møder med PPR på skolen, når samarbejdet mellem skoleforvaltningen og PPR fungerer mindre godt. Dette kunne tyde på en mere direkte arbejdsgang mellem PPR og skolelederen, hvis samarbejdet ikke fungerer på højere niveau.

Det kan måske overraske, at vi har fundet en tendens til, at lærere i kommuner med en høj grad af kompetenceudvikling i mindre grad angiver at være blevet tilbudt kompetenceudvikling, og i mindre grad angiver at have været på kurser og deltaget $\mathrm{i}$ inklusionsdage på skolen. Til gengæld anvender lærerne i kommuner med en høj grad af kompetenceudvikling i højere grad forskellige pædagogiske modeller, AKT-vejledere på skolen og sparring med medarbejdere fra skolens specialcenter. Med andre ord får lærerne mere sparring og støtte på skolerne.

I forhold til kommunernes strategier finder vi, at når graden af fælles værdier er høj på forvaltningsniveauet, og kvaliteten af samarbejdet mellem skoleforvaltningen og PPR er høj, så oplever skolelederne i mindre grad, at kommunens strategier er hensigtsmæssige i forhold til både samarbejdet mellem PPR og skole og tilrettelæggelsen af inkluderende læringsmiljøer. Dette kunne måske indikere, at skolelederne ikke føler sig repræsenterede i udformningen af strategierne.

Der er flere forskelle mellem kommuner, der har et højt socioøkonomisk indeks (altså større udgiftsbehov), og kommuner med et lavere socioøkonomisk indeks. I kommuner med et stort udgiftsbehov oplever skolelederne i mindre grad, at der foreligger strategier i kommunen i forhold til arbejdet med inklusion. 
Bestyrelsesformændene i kommuner med et lavere udgiftsbehov oplever i større grad, at forældrene bakker op om målet om øget inklusion, mens lærerne i højere grad vurderer, at forældrene ikke har kendskab til målsætningen. Derudover holdes der færre faste møder med PPR på skolerne i kommuner med en høj socioøkonomisk indeksværdi.

Endelig synes elevernes sociale trivsel ifølge lærerne at være højest i kommuner, der startede inklusionsprocessen tidligt, der har en høj grad af fælles værdigrundlag, der har en høj grad af kompetenceudvikling, der kun har en lille ændring i inklusionsprocenten, og hvis værdi på det socioøkonomiske indeks er lille. Altså er elevernes trivsel størst i de kommuner, der enten oplever de mindste forandringer eller er bedre rustede til at tage sig af forandringerne. 


\section{Afsluttende analyser}

Af Siddhartha Baviskar, Camilla Brørup Dyssegaard, Niels Egelund og Christopher de Montgomery

Dette kapitel indeholder sammenfatningen af en analyse af indsatser og faktorer med betydning for en succesfuld inklusion i forhold til de mål, der er aftalt mellem regeringen og KL. Disse mål er, at:

- andelen af elever, der skal inkluderes i den almindelige undervisning øges

- andelen af elever, der får 2 eller derunder i læsning, retstavning og matematisk problemløsning i 9. klasses afgangsprøve, skal være reduceret i 2015 og reduceres yderligere frem mod 2018

- elevernes trivsel fastholdes i takt med omstillingen til øget inklusion

- bedre resultater fra national præstationsprofil i dansk og matematik

- overgang til ungdomsuddannelse.

Først er der foretaget en undersøgelse af udviklingen i kommunerne i forhold til inklusionsmålsætningerne og en række forklarende variable samt sammenhængen mellem disse variable med henblik på at identificere indsatser og faktorer af særlig betydning for en succesfuld inklusion.

Endelig er det undersøgt, hvad der kendetegner de skoler, hvor der er henholdsvis størst og mindst forskel på lederes og læreres holdninger til inklusion, samt de skoler, hvor både ledere og lærere ligger relativt højest og lavest med hensyn til holdninger til inklusion.

Det har krævet et meget stort antal analyser, som i øvrigt er vanskeliggjort ved det relativt lave antal respondenter, og endelig gør de lave svarprocenter fra især lærerne undersøgelserne mindre sikre. Definition af variable og dokumentation for resultaterne såvel som statistiske analyser af signifikans findes i det særskilte Appendiks til denne rapport i form af tekst, tabeller og figurer.

Sammenfattende gælder, at det lader sig gøre med rimelig sikkerhed at identificere de sammenhænge, der præsenteres i punktform nedenfor. 


\section{Inklusionsmålsætningerne}

I det følgende analyseres inklusionsmålsætningerne i forhold til en række forklarende variable. Analyserne er gennemført af Siddhartha Baviskar og Christopher de Montgomery.

\section{Inklusionsprocent}

I forhold til at opnå en høj inklusionsprocent er der sammenhæng med følgende (figurerne B3.33-B3.49 i Appendiks):

- En høj grad af fælles værdigrundlag på forvaltningsniveauet

- En høj grad af økonomiske incitamenter for inklusion

- At lærerne føler sig fagligt rustet til at håndtere inklusionsudfordringer

- At lærerne bakker op om inklusionsmålsætningen

- At forældrene bakker op om inklusionsmålsætningen (skolebestyrelsesformænds vurdering)

- At skolebestyrelsesformænd ytrer tilfredshed med skolens arbejde med elevernes trivsel.

Alt i alt er der tale om forhold, der virker særdeles logiske, og som genfindes i de kvalitative resultater.

\section{Lavere antal med karakteren 2 eller derunder}

I forhold til at reducere andelen af elever, der får 2 eller derunder som samlet gennemsnit i læsning, retskrivning og matematisk problemløsning i 9. klasses afgangsprøve er der sammenhæng mellem følgende (figurerne B3.50-B3.67 i Appendiks):

- En lav inklusionsprocent

- Lærere har høj vurdering af deres samarbejde med PPR

- Lærere har høj vurdering af omfanget af tilgængelige ressourcer til inklusion

- Forældre(par) udtrykker utilfredshed over elever, der er fastholdt $i$ almenundervisningen eller er ført tilbage fra specialklasser eller specialskoler

- Kommunernes udgifter per elev er høje.

Det skal her bemærkes, at der også her synes at være tale om sammenhænge, der kan virke naturlige. En øget inklusionsprocent vil med høj sandsynlighed medvirke til, at andelen af elever med relativt svage faglige kompetencer også øges, og det må sænke karakterniveauet, herunder foranledige, et flere elever får karakteren 2 eller derunder. 
Det virker ligeledes naturligt, at et godt samarbejde mellem lærere og PPR vil kunne øge nogle elevers udbytte af undervisningen. Hvis lærerne mener, at der i højt omfang er tilgængelige ressourcer til inklusion, er det naturligt, at det faglige niveau hæves. Hvis forældre udtrykker utilfredshed over inkluderede elever, kan dette føre til, at inklusionen sænkes, og dermed vil karakterniveauet som nævnt ovenfor formentlig stige. Et højt udgiftsniveau pr. elev bør alt andet lige medvirke til, at det faglige niveau øges. Relationerne har ikke kunnet afprøves i det kvalitative materiale.

\section{Bedret national præstationsprofil}

I forhold til et samlet godt resultat i den nationale præstationsprofil ved de nationale test i dansk (sprogforståelse, afkodning og tekstforståelse) ses følgende sammenhænge (figurerne B3.68-B3.85 i Appendiks):

- Høj grad af kompetenceudvikling i forhold til inklusion

- Stort antal aktiviteter, lærerne har deltaget i i forbindelse med arbejdet med inklusion

- Høj vurdering hos lærere af graden af kompetenceudvikling, de er blevet tilbudt

- Høj vurdering hos skolelederne af antal tilgængelige ressourcer for lærere/pædagoger i forhold til inklusion.

At høj grad af kompetenceudvikling, deltagelse i aktiviteter og positiv vurdering af disse i forhold til inklusion har sammenhæng med bedre resultater i de nationale test, er ny og interessant viden. Det er endvidere interessant, at hvor skolelederne vurderer, at der er mange tilgængelige ressourcer for lærere og pædagoger i forhold til inklusion, der øges testresultaterne.

\section{Overgang til ungdomsuddannelse}

I forhold til at opnå en høj procentdel, der er fortsat til en ungdomsuddannelse, er der følgende sammenhænge (figurerne B3.86-B3.102 i Appendiks):

- Lærerne føler sig fagligt rustet til at håndtere inklusionsudfordringer

- Lærerne bakker op om inklusionsmålsætningen

- Forældrene bakker op om inklusionsmålsætningen (skolebestyrelsesformænds vurdering)

- Skolebestyrelsesformænd er tilfredse med skolens arbejde med elevernes trivsel. 
I forhold til de afdækkede sammenhænge er det interessant, at de elever, der har afsluttet 9. klasse i 2012, 2013 og 2014, kun har haft kortvarigt direkte udbytte af de initiativer, skolerne har sat i værk efter inklusionsprocessens start i skoleåret 2012/13. Det må derfor antages, at der er nogle underliggende sammenhænge mellem lærere, forældre og skolernes generelle aktiviteter og lærerne, forældrene og skolernes arbejde med inklusion. Disse generelle aktiviteter må så formodes at have indflydelse på hvor mange af skolernes elever, der umiddelbart går videre i en ungdomsuddannelse.

\section{Trivsel}

I forhold til at minimere den procentdel af elever, som lærerne mener ikke trives fagligt eller socialt, er der sammenhænge med (figurerne B3.103-B3.120 i Appendiks):

- Lærerne føler sig fagligt rustet til at håndtere inklusionsudfordringer

- Lærerne bakker op om inklusionsmålsætningen

- Forældrene bakker op om inklusionsmålsætningen (skolebestyrelsesformænds vurdering)

- Skolebestyrelsesformænd er tilfredse med skolens arbejde med elevernes trivsel.

Det fremgår her, at der er tale om nøjagtigt de samme sammenhænge, som gjaldt for overgang til ungdomsuddannelse. Dette styrker antagelsen om, at der er nogle underliggende sammenhænge mellem lærere, forældre og skolernes generelle aktiviteter og lærerne, forældrene og skolernes arbejde med inklusion - generelle aktiviteter, som formodes at have indflydelse på, at der er få af skolernes elever, der ikke trives fagligt og socialt.

\section{Forskelle og ligheder mellem skoleledere og læreres holdning til in- klusion}

Analyserne af spørgeskemasvar fra henholdsvis skoleledere og lærere har afsløret, at der er meget store forskelle mellem de to gruppers svar. I det følgende vil dette blive belyst kvalitativt og kvantitativt.

\section{Kvalitativ afdækning af forskelle mellem leder- og lærersvar}

For at få afdækket baggrunden for forskellene kvalitativt er der i 2015 stillet fire ekstra spørgsmål til skoleledere og PPR-ledere. De kvalitative analyser er gennemført af Camil- 
la Brørup Dyssegaard og Niels Egelund. Spørgsmålene dækker: Strategiske mål for inklusion, kompetenceudvikling, læreres oplevelse af egne kompetencer og brug af inklusionsvejleder.

\section{Strategiske mål}

Det første spørgsmål har lydt: Hvad vurderer du er grunden til "gabet" mellem de strategiske mål for inklusion, herunder skoleledernes mål og lærernes overtagelse af målet $i$ sporgeskemaanalysen $i 2013$ og 2014 (fx siger henholdsvis 79,3 pct. og 74,5 pct. af lederne, at de bakker op om inklusion, mens andelene for lærerne er 18,7 pct. og 12,9 pct.)?

I svarene fra skolechefer og PPR indgår to overordnede temaer, dels at der ved inklusion er tale om en top-down-beslutning, hvor der på lærerniveauet ikke er en tydelig forståelse af, hvad formålet og målsætningen for inklusion er, dels at der er tale om en betydelig frustration blandt lærerne.

Hvad top-down-beslutning angår, ligger der en lovgivning om inklusion, besluttet af et meget stort flertal på Christiansborg. På kommunalt niveau er der også i alle kommuner truffet beslutninger om inklusion. Selv om det er gjort meget forskelligt, lige fra at man har besluttet sig for at nedlægge næsten samtlige specialtilbud, til at man ikke har villet lægge sig fast på et måltal, men bare har det som en hensigt. På skolerne har skolelederne skullet forholde sig loyalt til kommunens mål og har haft ansvaret for at implementere en målsætning for inklusion på deres skoler. Dette afspejles i ledernes overvejende positive svar. Det ses tydeligt, ud fra lærernes helt overvejende negative svar, at det ikke i særlig høj grad er lykkedes for skolelederne at få det pædagogiske personale til at føle et fælles ansvar for eller have kendskab til, hvad skolens målsætning for inklusion reelt er. Skolelederne har ikke entydigt fået anlagt en ledelsesform, som tydeligt og velbegrundet forklarer deres visioner om inklusion samtidig med, at lærerne har fået lejlighed til at udtrykke deres egne holdninger til inklusion - bottom-up. På denne måde er der ikke opnået et fælles ansvar for og forståelse af inklusion på de enkelte skoler. Målene for inklusion bliver udtydelige, jo længere ned i systemet man kommer. En skolechef udtrykker det således: "Skolelederne erlængere i processen, personalet mangler at acceptere beslutningen og siger, at de allerede har inkluderet".

Lærernes frustration består i, at det i det daglige arbejde er dem, der står med udfordringerne med eleverne undervisningen og føler usikkerheden. Der er tydelige holdningsmæssige barrierer hos lærerne, der også er påvirket af negativ debat i medierne. Hertil kommer frustration over lockouten i 2013, de efterfølgende nye arbejdstidsregler og implementeringen af skolereformen i 2014. En skolechef siger: "Lærerne er konservative, modvillige og $i$ arbejdskamp. Der mangler kompetencer til de opgaver, samfundet Har defineret for dem". En anden siger: "Lærerne har ikke det overskud, der skal til, de slikker sår, og der er 
samtidig stillet sporgsmål ved deres professionalisme".

\section{Kompetenceudvikling}

Næste spørgsmål til skolechefer og PPR-ledere var: Hvad vurderer du er grunden til "gabet" mellem skoleledernes oplysninger om kompetenceudvikling og lærernes oplysninger om det samme i spørgeskemaanalysen i 2013 og 2014 (fx svarer henholdsvis 72,4 pct. og 61,2 pct. af lederne, at de har afholdt pædagogisk dag om inklusion, mens kun 33,6 pct. og 31,7 pct. af lærerne siger, at de har deltaget i en pædagogisk dag om inklusion)?

Her dækker svarene to temaer: indhold og kvalitet samt ønsker om yderligere kvalificering.

Med hensyn til indhold og kvalitet i kompetenceudvikling svarer de adspurgte, at de kurser, der har været givet, i høj grad har været teoretisk orienterede. Som en PPRleder udtaler: "Der har været for meget "Kloge Åge" og for lidt praksisanvisninger, og nogle lærere har oplevet, at oplægsholdere taler ned til dem ". Noget af efteruddannelsen har været af så generel karakter, at "lærerne måske ikke har registreret, at det drejede sig om inklusion", som en skolechef udtrykker det. Flere af de interviewede påpeger også, at kursusudbuddet ikke har været finafstemt mellem bund og top, dvs. ikke var rettet mod, hvad lærerne selv mener, de har brug for. Et eksempel er: "Der skal være fokus på, hvad der får inklusion til at lykkes i praksis - det er det samme problem, vi har set i forhold til undervisningsdifferentiering, der også har været noget, vi har talt meget om, men ikke har fået til at fungere $i$ praksis".

Det andet tema er, at der tilsyneladende er åbenlys efterspørgsel efter kompetenceudvikling i form af traditionelle kurser. Som en skolechef udtrykker det: "Lærerne mangler en forståelse af, hvad kompetenceudvikling er. De vil have kurser, vi vil have aktionslæring, så lærerne bliver aktivt involverede i at udvikle deres praksis". I forhold til de tidligere nævnte udfordringer i praksis gælder også, at uanset hvor meget kompetenceudvikling man har fået, er det svært at arbejde inkluderende, og der vil løbende være situationer, hvor man skal finde løsninger, man ikke synes, at man har. En PPRleder udtrykker det således: "Lærerne forveksler kvalificering med kompetencer. Inklusion er svær. Selv når der er effekt, går det galt en gang imellem."

\section{Oplevelse af egne kompetencer}

Skolechefer og PPR-ledere er blevet spurgt: Hvad vurderer du er grunden til, at kun 9,3 pct. og 10,1 pct. af lærerne i 2013 og 2014 giver udtryk for, at de er rustede til at varetage inklusionsopgaven? Der kan her identificeres tre temaer: afmagt, teamsamarbejde og tolærerordning. 
Det første tema, afmagt, har en høj grad af sammenhæng med det tidligere nævnte spørgsmål om kompetenceudvikling. En skolechef siger: "Ideologien er måske på plads, men håndteringen er der ikke. Larerne kommer metodisk til kort, de mangler konkrete redskaber, en metodekasse". Det nævnes også, at lærerne ikke er gode nok til at differentiere eller lede et læringsmiljø, og at de derved ofte står i situationer, hvor de føler sig utilstrækkelige.

Det andet tema, teamsamarbejde, rummer det, at lærerne ikke formår at skabe et reelt teamsamarbejde. En skolechef siger: "Lærerne føler sig fortabte og modvillige, når de opdager, at det er den enkelte lærers ansvar at få inklusionen til at lykkes, og ikke ser det som et fxlles ansvar for hele teamet". En PPR-leder siger: "Når lærere udtrykker, at de ikke er klædt på til inklusionsopgaven, er det en måde at lægge ansvaret fra sig på, frem for at trække på de ressourcer, der er i teamet. Der skal opleves fællesskab". Én kommune har uddannet teamfacilitatorer, som skal hjælpe med at fremme forståelsen af, at det at inkludere elever er et fælles ansvar for teamet.

Det tredje tema, tolærerordning, går på, at lærerne føler, de allerede er udfordret nok af mange "inklusionsbørn" i klassen, og er nervøse for, om de kan slå til, hvorfor de ønsker en ekstra lærer til stede. Det går på tværs af svarene fra skolechefer og PPRledere, at tolærerordning er et generelt svar på, hvad der skal til for at klare vanskelige situationer.

\section{Brug af inklusionsvejleder}

Det sidste ekstra spørgsmål til skolechefer og PPR-ledere er: I analysen af spørgeskemadata fra 2013 og 2014 viser det sig, at kun henholdsvis 10,4 pct. og 12,5 pct. af lærerne siger, at de har gjort brug af inklusionsvejleder, hvordan vurderer du det resultat? Svarene på dette spørgsmål placerer sig under to temaer: kulturkløft og kvalitet.

Det første tema, kulturkløft, dækker, at det for mange lærere kræver en kulturændring at acceptere, at der er nogen, der er specialister. Dette gælder både for den lærer, der søger hjælp/støtte, og for ressourcelæreren, som skal agere specialist over for en kollega. Der har været en kultur med at spørge de nærmeste kolleger til råds. Man har været vant til, at man kunne aflevere et problem, og sådan er det ikke længere.

Det andet tema, kvalitet, går på vejlederens faglige og personlige kompetencer. En skolechef erkender, at det ikke altid er de dygtigste lærere, man har sendt på uddannelse til at blive inklusionsvejledere, nogle af dem har været de lærere, der trængte mest til en opgradering, og det er naturligvis vanskeligt for disse at opnå tilstrækkelig legitimitet blandt kollegerne. I et par kommuner har man også været nødsaget til at sende inklusionsvejledere på kurser i voksenvejledning, for at de kunne udfylde deres roller. En PPRleder siger: "Det er en vanskelig rolle at være kollega, der kan "sælge" kompetencer". En skolechef siger: "Om man søger vejledning, afhænger af, om man synes, at man kan bruge personen". 
I øvrigt mærker man tydeligt, at det er på AKT-området, der er størst brug for vejledning.

\section{Kvantitativ afdækning af forskelle mellem leder- og lærersvar}

De kvantitative analyser er gennemført af Siddhartha Baviskar og Christopher de Montgomery. Der er to spørgsmål, der søges besvaret:

1. Hvilke faktorer kendetegner skoler med relativt høj forskel mellem skolelederne og lærernes holdning til inklusion?

2. Hvilke faktorer kendetegner skoler, hvor både skoleledere og lærere støtter inklusionsmålsætningen?

Udgangspunktet for at besvare det første spørgsmål er hypotesen, at gabet mellem skolelederes og læreres holdning til inklusionsmålsætningen og mangel på samme kan forklares ved at se på graden af forskelle mellem de to grupper i forhold til en række faktorer, som forskningslitteraturen tyder på er centrale i inklusionsprocessen.

Disse faktorer er eksempelvis samarbejde med PPR, økonomiske incitamenter til inklusion, kompetenceudviklingsaktiviteter og forældrenes støtte til inklusionsmålet (Dyssegaard et al. 2013; Danmarks Evalueringsinstitut 2011; Kommunernes Landsforening 2011; Sløk 2011). Fx spiller PPR en nøglerolle i processen målrettet en reduktion i antallet af elever, som bliver visiteret til specialskoler eller specialklasser, og den rolle er under udvikling fra en med fokus på udredning til en anden med større vægt på vejledning og rådgivning af skolens pædagogiske personale i forhold til integrationen af elever med særlige undervisningsbehov som del af en almindelig klasse. Skoleledere og læreres vurderinger af PPR's rolle i at fremme inklusion kan afvige fra hinanden, og størrelsen af den forskel kan delvis forklare, om lederne og lærernes holdninger til inklusionsmålsætningen er meget forskellige. Udover disse faktorer inkluderes i analysen som kontrolvariable en række andre faktorer, der kunne tænkes at påvirke sammenhængen mellem disse inklusionsrelaterede processer og holdninger til inklusion, $\mathrm{fx}$ antal elever per pædagogisk personale og andel elever i specialklasser.

\section{Data}

For at besvare de to spørgsmål vedrørende skolelederne og lærernes holdninger til inklusionsmålsætningen har vi anvendt data fra spørgeskemaundersøgelserne blandt skoleledere og lærere - i alt 106 skoleobservationer. I analysen indgik der besvarelser fra 37 
skoler fra runde 1 (2012/2013), 28 skoler fra runde 2 (2013/2014) og 41 skoler fra runde 3 (2014/2015).

Analysen af forskelle mellem de skoler, som indgår i denne analyse, og dem, der ikke indgår, tyder på en vis underrepræsentation af mere ressourcestærke elever. Men denne forskel er ikke stor nok til at være statistisk signifikant. Det betyder, at resultaterne af analysen måske er mindre retvisende for skoler med mere ressourcestærke elever.

Tabeller i Appendiks giver en oversigt over, hvordan vi har målt de forskellige faktorer, som indgår i analysen. De viser blandt andet, hvordan vi har målt forskellen og enighed mellem skoleledere og lærere vedrørende inklusionsmålsætningen (de afhængige variable i analysen) samt de indikatorer, der er brugt til at forklare dem (de uafhængige variable) fx vurdering af samarbejdet med PPR og ressourcer, som er tilgængelige for lærerne i deres arbejde med inklusion.

\section{Resultaterne}

Resultaterne fra regressionsanalysen præsenteres i tabel B3.1 i Appendiks.

Samlet set peger analysen på, at fem faktorer har betydning for forskelle og enighed mellem skoleledere og læreres syn på inklusionsmålsætningen i samme skole. Skoler, hvor lærerne bakker mindre op omkring inklusionsmålsætningen end lederne, er kendetegnet ved følgende to forhold:

- Lærerne oplever i mindre grad end lederne, at de har et incitament til at inkludere elever med særlige behov

- Lærerne oplever i mindre grad end lederne, at forældrene bakker op om inklusionsmålsætningen.

Følgende tre forhold kendetegner skoler, hvor både skoleledere og lærere støtter inklusionsmålsætningen:

- Både skoleledere og lærere oplever, at der er et godt samarbejde med PPR i forhold til rådgivning og vejledning, udredning af elever og supervision

- Både skoleledere og lærere oplever, at der er god adgang til inklusionsrelaterede ressourcer, fx inklusionsvejleder og AKT-vejleder

- Der er gode, konkrete muligheder for lærerne til at opbygge deres kompetencer $\mathrm{i}$ at fremme inklusion.

Disse resultater bekræfter således kvantitativt nogle af resultaterne fra den kvalitative forskning om inklusion i Danmark. 


\section{Hvad har haft betydning for inklusionsprocessen fra 2013 til 2015?}

Indsamlingen af kvalitative data i 2013 og 2014 har tjent som grundlag for i 2015 at kunne vurdere, hvad der har haft betydning for inklusionsprocessen i de tolv kommuner. Der er derudover i 2015 stillet nogle ekstra spørgsmål til skolechefer og PPR-ledere, hvor de skulle reflektere over forhold, der har haft henholdsvis fremmende og hindrende indflydelse på omstillingen til inklusion. Analyserne er gennemført af Camilla Brørup Dyssegaard og Niels Egelund.

\section{Inklusionsfremmende tematikker:}

I det følgende nævnes og karakteriseres fem tematikker, der er fundet at have inklusionsfremmende virkning.

\section{Fælles værdigrundlag}

Gennemgang af den internationale forskning viser, at etableringen af et fælles værdigrundlag forstået på den måde, at der er klare målsætninger for, hvad man ønsker at opnå, er af helt afgørende betydning for at skabe inklusion (Dyssegaard m.fl., 2013).

Vedtagelse af inklusionsloven i 2012 og kommuneaftalen i 2013 har sat de overordnede værdier og rammer for inklusion. En skolechef siger: "Kommunalpolitikken, som det kan ses i mange udvalgsrapporter, viser, at vi vil inklusion". Alle tolv kommuner i undersøgelsen har arbejdet med at etablere et fælles værdigrundlag for inklusion, først og fremmest på det politiske niveau og på forvaltningsniveauet. Som en skolechef siger: "Vi tog en beslutning om, at vi ville den bevxgelse, og den gav god mening". Ud over skoleforvaltningen er PPR en vigtig part i processen, og det gælder her, at PPR i nogle kommuner er placeret i et andet forvaltningsområde, med de udfordringer det kan give med hensyn til inddragelse i processen og ejerskab til processen.

Det har været målet at skabe et fælles værdigrundlag, der rækker fra det politiske niveau og forvaltningsniveauet ud til de enkelte skoler og institutioners bestyrelser, ledelser, lærere og pædagoger. Nogle kommuner har startet processen tidligt, mens andre først er kommet i gang i 2013, og da det naturligt er en proces, der tager tid, er det også forskelligt, hvor langt man er nået i 2015. Dertil kommer, at man i forskellige kommuner har haft forskellige udfordringer i forhold til at få værdigrundlaget etableret på skolerne, dels i måden processen er grebet an på, dels i skolestrukturelle forhold og endelig i forbindelse med ændringer i forvaltningsstrukturer og bemanding. I flere kommuner bærer processen præg af, at der har været en for stærk top-down-styring, og at man ikke har formået at få medarbejderne forpligtede på at overtage værdigrundlaget. En interviewet 
siger: "En meget stor udfordring har været, at halvdelen af skolelederne ikke fär rejst de rigtige mindsets, der kan motivere lærerne". Manglende forpligtelse ses tydeligt i de meget betydelige forskelle på kvantitative besvarelser fra henholdsvis skolebestyrelsesformænd, skoleledere og lærere. I den kvalitative undersøgelse er der søgt svar på disse forskelle, og det viser sig her, at det især er tre forhold, der gør sig gældende: lærernes følelse af afmægtighed, manglende gennemskuelighed $i$ ressourcetildeling og PPR's funktion - forhold, som dækkes i de temaer, der nævnes i det følgende.

\section{Strategier}

For at føre det fælles værdigrundlag ud i livet må der vedtages et sæt af strategier, som bygger på den fælles målsætning for inklusion. Der er strategier, der har været fælles for alle tolv kommuner. Her kan nævnes kompetenceudvikling af det pædagogiske personale, fokus på en øgning af konsultativt arbejde i PPR og en målrettet indsats for at fastholde så mange elever i almentilbud så længe som muligt. Der er strategier, som er valgt $\mathrm{i}$ et stort flertal af kommuner, fx økonomiske incitamenter, og som nu er under overvejelse i de resterende kommuner.

Der er også strategier, der er meget forskellige fra kommune til kommune. En række kommuner har satset på reflekterende lærerteam - og har i øvrigt også arbejdet med det som led i LP-modellen. Der er kommuner, der som strategi har haft den tilgang, at specialtilbuddene i kommunen skulle reduceres drastisk. En skolechef siger om kommunens strategi: "Alle børn har krav på at være en del af fxllesskabet og profitere af det; fællesskabet er styrken. Derfor skal så få som overhovedet muligt gå uden for almentilbuddet". Det har naturligvis kvantitativt været særdeles effektivt, men har givet modstand, og kvaliteten betvivles også i mange tilfælde. Der er kommuner, som nedlægger specialtilbuddene "nedefra", så der ikke længere optages elever i børnehaveklassen/1. kl., hvorved en specialklasse eller specialskole på 9-10 år vil være afviklet. Der er kommuner, der har satset stærkt på tidlig indsats, og der er kommuner, som har samlet specialtilbud på almenskoler, hvad der kan give positive synergieffekter, idet speciallærere og almenlærere blandes.

Strategierne kompetenceudvikling, PPR's konsultative funktion, økonomiske incitamenter og tidlig indsats er tematikker, der behandles særskilt nedenfor.

\section{$\varnothing$ konomiske incitamenter}

Princippet om, at en skole får et beløb, hver gang der inkluderes en elev, har vist sig at være særdeles effektivt, og det står i fuldstændig kontrast til tidligere praksis, hvor en skole ikke blev belastet økonomisk af at ekskludere en elev, ud over måske at miste den 
betaling pr. elev, de fleste kommuner tildeler grundressourcer til. Besvarelserne i de kvalitative data peger på, at strategien økonomiske incitamenter sammen med det fælles værdigrundlag har været de stærkeste inklusionsskabende faktorer.

De økonomiske fordele opnås ved at undlade at ekskludere de elever, der er i skolens distrikt, altså at undgå udgifter, idet skolen forlods har fået alle de ressourcer, der skal anvendes til supplerende undervisning, inklusionsfremmende initiativer og specialundervisning. For den almindelige lærer eller pædagog kan det imidlertid være svært at gennemskue, hvad ressourcerne bliver brugt på. Risikoen for, at lærere og pædagoger synes, de ikke får de ressourcer, der skal til for at inkludere, vil være betydelig.

Ved den afsluttende dataindsamling er der spurgt til netop det forhold, at lærere ikke synes, at der følger ressourcer med. Undersøgelsesrunderne, også den sidste, kan dokumentere, at der er overført ressourcer til inklusion af elever både i forbindelse med incitamenterne, men også ved at der er rammesat midler til skolernes inklusion. Der er imidlertid sket det i mange kommuner, at der har været generelle nedskæringer, nogle steder endda meget massive nedskæringer. Det kan illustreres med følgende citater fra en skolechef: "Vi er nok ved at løbe fra det, vi har lovet - det virker som om, at man giver $180.000 \mathrm{kr}$. med den ene hånd og tager $260.000 \mathrm{kr}$. med den anden". "En positiv faktor har været den politiske dimension, man ønskede inklusion, og det drejede sig om frllesskabet, men oven $i$ det skal der spares nogen penge. Jeg taler lige ud af posen, der blev reduceret med først $5 \%$ så $10 \%$ på det specialiserede område".

\section{PPR's ændrede funktion}

PPR er naturligvis en central spiller i inklusionsprocessen. Mens PPR historisk set har haft sin primære rolle $i$ at vurdere elever og indstille til specialpædagogiske foranstaltninger, er rollen gradvist ændret i de senere år. I alle tolv kommuner er der arbejdet på, at PPR's konsultative virksomhed skulle øges, således at den individualiserede virksomhed med udarbejdelse af pædagogisk-psykologiske vurderinger er reduceret. PPR's arbejde med at øge den konsultative praksis er grebet forskelligt an i kommunerne, men der er dog også fællestræk.

Samtlige kommuner har ladet sig inspirere af KL's "Pejlemærker for fremtidens PPR". Dette har resulteret i, at flere PPR-enheder har arbejdet med at tydeliggøre deres funktion. En del af PPR-kontorerne har endvidere udarbejdet et ydelseskatalog målrettet skolerne, hvor bl.a. procedurer for visitation er beskrevet, kursusmuligheder, supervision. PPR-lederne giver udtryk for en blandet modtagelse af disse ydelseskataloger på skolerne. Enkelte kommuner er gået bort fra at færdiggøre ydelseskataloget. Dette begrunder de med, at de enkelte skolers behov varierer meget, hvorfor flere PPR-kontorer har valgt at forventningsafstemme opgaverne på skolen med den enkelte skoleleder. Et 
andet problem, som nævnes af PPR-lederne er, at skolelederne ikke altid formår at udbrede kendskabet til aftalerne indgået med PPR videre til det pædagogiske personale. Et tredje forhold er, at de retningslinjer, der er lagt for visitation, ikke nødvendigvis følges af skolelederne. En PPR-leder udtaler, at det er svært at komme i kontakt med skolelederne: "Jeg har en forhåbning om, at nu hvor vi har fået en distriktsopdeling, at skolelederne og områdelederen (PPR-medarbejder) kan få et formaliseret samarbejde og derigennem opnå en større forventningsafstemning".

Der er flere PPR-ledere, som beskriver, at det fortsat kan være svært for skolerne at acceptere den store vægtning af det konsultative arbejde. I en enkelt kommune mener skolechefen, at PPR er for restriktiv over for at udarbejde pædagogisk-psykologiske vurderinger, og der synes stadig at være skoleledere og lærere, som foretrækker den gamle funktion som enheden, der kan sortere elever væk eller skaffe ressourcer. En PPR-leder siger også: "En udfordring i forhold til den konsultative tilgang er, at når vi afviser at lave en pædagogisk-psykologisk vurdering, føler lærerne, at vi ikke tror, at der er et problem, hoad der er en vanskelig situation. Til gengæld kan daginstitutionerne ikke fä armene ned, de bruger ydelseskataloget meget, og vi kan se, at det virker".

Et gennemgående træk i kommunerne er, at PPR-medarbejderne er blevet flyttet ud i distrikter og har deres kontorer på skolerne. Dette vurderer både skolechefer og PPR-ledere som positivt i forhold til at opnå forventningsafstemning mellem PPR og den enkelte skole, at have direkte adgang til en psykolog, få nedbragt ventetiden og udbygget det tværfaglige samarbejde. I mange kommuner har decentraliseringen også betydet, at der er etableret distriktsteam, hvor bl.a. socialrådgivere indgår. De menige PPRmedarbejdere er imidlertid ikke altid glade for ændringen, idet de føler, at de mangler faglig sparring.

Undersøgelsens data peger på, at den konsultative tilgang faktisk har været værdifuld i inklusionsprocessen, men at det kræver, at PPR har medarbejdere med de didaktiske kompetencer, der efterspørges af lærerne, og at man på skolerne ønsker at modtage den viden, medarbejderne er i besiddelse af. Hvad sidstnævnte angår, anvender flere kommuner betydelige midler på at efteruddanne PPR-medarbejderne i supervision, observationer og mødeledelse, hvilket alle er centrale elementer i en konsultativ praksis.

\section{Teamsamarbejde}

Undersøgelsen peger i retning af, at teamsamarbejde er af afgørende betydning for inklusionsprocesserne. Det drejer sig både om samarbejde i skolernes ledelser og i lærerteam, blandt PPR-medarbejdere og det tværprofessionelle teamsamarbejde. Teamsamarbejde har været en af de strategier, en del kommuner har anvendt, herunder har introduceret tidligt, bl.a. i forbindelse med LP-modellen. 
Arbejdet med at etablere velfungerende lærerteam har til formål, at inklusion af elever ikke længere skal ses som den enkelte lærers ansvar. Det er teamet, som har ansvaret for opgaven med at inkludere. Det vigtige er, at både undervisningspraksis og teamets kultur og samarbejde giver teammedlemmerne mulighed for at reflektere over og udvikle egen professionel praksis. I én kommune kommer skolechefen helt ud til de enkelte lærerteam for at deltage i og understøtte udviklingen.

Det er centralt i flere af kommunerne, at medarbejderne i PPR har en professionel sparring. Som eksempel kan gives en kommune, hvor PPR-medarbejderne arbejder ud fra en specifik analysemetode i fællesskab. Ingen sager kan henvises til visitation, uden at psykologerne har drøftet sagen på det fælles ugentlige møde. Et andet eksempel er en kommune, hvor der en gang om ugen er faglig sparring, hvor medarbejderne drøfter inklusionsudfordringer, enkeltsager, supervisionsforløb m.m. En PPR-leder udtrykker det således: "Vi italesætter tingene som processer og er nysgerrige, hoad der er med til at mindske fokus på den enkelte skoles, klasses, lærers, pædagogs og elevs vanskeligheder".

Et andet tværgående tema omkring teamsamarbejde er, at kommunerne i stor udstrækning er ved at udbygge det tværprofessionelle teamsamarbejde. Dette ses $\mathrm{fx} i$ kommuner, hvor der er en distriktsopdeling, hvor psykologer, konsulenter, talepædagoger og socialrådgivere er placeret sammen, letter og intensiverer sagsbehandlingen. Dette er også med til at understøtte en tidlig indsats omkring udsatte elever. En PPR-leder udtaler: "Vi behøver at have en langt højere grad af fokus på det tværfaglige. Det er et nødvendigt onde, og det er ikke rimeligt, at enkeltsager skal over flere afdelinger i forvaltningen". Fælles for de 12 kommuner er, at det tværfaglige samarbejde skal sikre både en tidlig indsats omkring børnene, og at overgange mellem dagtilbud og skole og mellem skole og ungdomsuddannelse foregår på en måde, hvor der er sammenhæng. I den forbindelse har flere kommuner etableret familiehuse. En PPR-leder siger: "Tanken med det nye familiehus er, at der skal foregå forebyggelsesaktiviteter. Det væsentlige er, at familierne oplever et andet fora at mødes på end forvaltningen, så der sikres et trygt samarbejde mellem familien og rådgivere". Der er to eksempler på kommuner, der sågar har etableret tilbud til forældre umiddelbart før og efter børns fødsel.

\section{Inklusionshæmmende tematikker}

Det har i analyserne af de kvalitative data vis sig, at der kan identificeres seks tematikker, der har udpræget hæmmende virkning på omstillingen til inklusion. 


\section{For mange ændringer på én gang}

I perioden fra 2013 til 2015 er der sket mange ændringer. Først implementeringen af inklusionsloven, så lov 409 om lærernes tjenestetid og så til sidst implementeringen af skolereformen. På tværs af alle 12 kommuner opleves de mange ændringer som en meget stor hindring for at få inklusionen til at lykkes. Det fortælles, at der op til implementeringen af inklusionsloven var en ganske positiv tilgang til at ville arbejde med inklusion. Fra omkring 2000 har man diskuteret rummelighed, man har arbejdet med forskellige modeller, der sætter elevernes kontekst i centrum, og man har fra 2011 deltaget i kurser om inklusion, bl.a. arrangeret af Danmarks Lærerforening. L409 og skolereformen har betydet, at den positive tilgang i høj grad er forsvundet. En PPR-leder siger: "Før kunne vi skubbe til lærernes grænser og udfordre dem. Det kan vi ikke længere".

Et andet gennemgående tema i kommunerne er, at skolechefer og PPR-ledere mener, at skolereformen opleves som et positivt islæt til at fremme inklusion, den er ambitiøs, men opfattes også som meget teoretisk, forstået på den måde at idéerne og initiativerne ikke er koblet sammen med virkeligheden. Der er simpelthen for mange ting på én gang og ind imellem dårlig ledelse på skolerne. En PPR-leder siger: "Lærere bakkes ikke nok op af deres skoleledere. Der er behov for nogle tydelige ledelsesmandater. Det kan godt være, at der er kommet en reform og har varet en konflikt, men lærerne mangler retning $i$ deres arbej$d e^{\prime \prime}$.

L409 giver flere udfordringer. En af dem, der nævnes, er, at der mangler både lærerarbejdspladser og grupperum til møder. I de to foregående runder af dataindsamlingen viste det sig, at der kunne være ventetid på at få aftaler med PPR. Nu beretter flere PPR-ledere, at lærernes nye arbejdstidsregler betyder, at det er vanskeligt for psykologerne at aftale tid til møder med lærere.

Af yderligere ændringer er, at flere kommuner har gennemført meget omfattende nedlæggelser af specialtilbud, som har givet fundamentalt anderledes vilkår for personalet, for eleverne og forældrene, og dette ud over de øvrige ændringer har givet anledning til spændinger og frustrationer, der i sig selv har påvirket den praktiske og daglige implementering af inklusion.

\section{Frontpersonalets afmægtighed}

Over alle tre dataindsamlinger har det vist sig, at det store flertal af lærerne ikke har et mindset, der er positivt over for inklusion. Såvel skolechefer som PPR-ledere udtrykker, at selv hvor lærere og pædagoger har en grundlæggende positiv indstilling til, at så mange elever som overhovedet muligt bør undervises i almenklasser, føler de sig ofte magtesløse, når de står midt i arbejdet, fordi de ikke oplever at have de redskaber, der skal til for at løse opgaven at undervise elever med særlige behov. Mange lærere føler, at 
de allerede inden inklusionsloven havde mange vanskelige elever i deres klasser, elever, de ofte benævner som "inklusionselever", og at de føler sig udfordrede i forhold til klasserumsledelse og undervisningsdifferentiering. En skolechef udtrykker det således: "Jeg kan være bekymret for, om der er de nødvendige kompetencer $i$ det daglige. Har de metodekassen"? Det udtrykkes på tværs af flere af kommunerne, at det i forhold til det konsultative arbejde er vanskeligt at skabe en kultur, hvor de pædagogiske medarbejdere arbejder systematisk og dokumenterende omkring det enkelte barn. En PPR-leder udtrykker det således: "Dialogmøder opleves af nogen som der, hvor man giver PPR en opgave, ikke som der, hvor man diskuterer en problemstilling". Der hersker stadig ønsker om at få segregeret børn med særlige behov, da lærerne giver udtryk for, at det er svært at arbejde med børnene i klassekonteksten. Der er også en udbredt opfattelse af, at det er synd for børnene at være inkluderede, da de ville have det meget bedre i et specialtilbud.

Det går også på tværs af kommunerne, at mange lærere har oparbejdet en modstand mod inklusion, da de føler, at de nu skal undervise elever, som tidligere ville have gået i specialtilbud. Der er også et urealistisk billede af, hvad målsætningen om 96 \% inklusion indebærer. En konsulent har udtrykt sig således: "Lærerne ser inklusion som lange rækker af hvide busser med vanartede børn, de nu skal have ind i deres klasser - selv om der $i$ praksis kun er tale om et barn i hver tredje klasse". En PPR-leder siger: "Skolens oplevelse stemmer slet ikke overens med virkeligheden".

Så godt som alle skoler i de 12 kommuner har fået uddannet inklusionsvejledere. I den kvantitative undersøgelse oplyser kun ca. en tiendedel af lærerne, at de anvender inklusionsvejledere. Blandt skolechefer og PPR-ledere opleves det som et tegn på, at nogle lærere har en modstand mod at bruge inklusionsvejledere, og i stedet bruger man andre lærere. En anden hindring kan være, at inklusionsvejlederen ikke opleves at have den legitimitet, der er nødvendig for at optræde i rollen som vejleder. Nogle steder har man ligefrem måttet opgradere vejlederne med et voksenvejledermodul. Et sted fortæller en skolechef, at nogle af de lærere, der er blevet uddannet til at være inklusionsvejledere, er lærere, der generelt var udfordrede i deres job og ikke havde tilstrækkelige kompetencer og legitimitet.

Ud over skolernes inklusionsvejledere er der i princippet i alle kommuner mulighed for at trække på vejledning fra nuværende eller tidligere specialklasser og specialskoler. Det er dog - med enkelte undtagelser - tilbud, der benyttes meget lidt, eller det er tilbud, man ikke mener at kunne bruge på grund af den forskel, der er mellem at undervise i et specialtilbud med syv elever og to voksne i klassen og en almenklasse med 28 elever og én voksen. Når dette er tilfældet, bestyrker det lærerne i opfattelsen af, at elever med særlige behov hører til i et specialtilbud, hvor undervisningen har så anderledes og bedre vilkår. 


\section{Negativ medieomtale}

Der har fra starten af 2013 været en meget omfattende, negativ mediedækning af inklusion. Landsdækkende TV har kørt reportager, der har givet indtryk af, at inklusionen er en katastrofe, og der er blevet bragt interview med fortvivlede forældre og lærere. Dette er fulgt op i såvel landsdækkende aviser som i lokale medier.

Det fortælles på tværs af kommunerne, at det har været med til at forme et negativt mindset hos lærere i forhold til inklusion. En skolechef udtrykker det således: "Skolers oplevelse af, at der er 4-6 inkluderede børn $i$ hver klasse, stemmer slet ikke med virkeligheden. Vi har brug for en modhistorie - det stopper ikke, selv om vi viser tallene. Vi skal fortælle de gode historier. Der er ingen forståelse af, hoorfor inklusion er en god idé".

Forældrene har også været påvirket af den negative medieomtale, og det er især de ressourcestærke forældre, der er blevet påvirket negativt, og også her beklages det fra skolechefer og PPR-ledere, at de gode historier enten ikke er blevet fortalt eller ikke er slået igennem i debatten.

\section{Elever med udadreagerende adfærd udfordrer meget}

Man beretter i næsten alle kommuner om, at elever med udadreagerende adfærd er en stor udfordring. Der synes at være en øget forekomst af sådanne elever, og der ses en tendens til, at disse elever bliver forbundet med inklusion. En PPR-leder udtrykker det således: "Børn, der giver problemer, er ikke nødvendigvis børn, der er inkluderede. Lærerne mangler redskaber til udadreagerende elever. For at inklusion kan lykkes, er det nok væsentligt, at der skabes tilbud på skolerne, der kan aflaste både disse elever, men også lærerne i løbet af en dag". En anden PPR-leder efterlyser også tilstedeværelse af "pusterum" - et fysisk sted, hvor eleven kan gå hen og få en pause - der uden ventetid kan fungere som aflastning.

\section{Andringer i forvaltningsstruktur og bemanding}

Det er et karakteristisk træk, at der i flere af de 12 kommuner er sket ændringer i forvaltningsstrukturen og bemandingen over de knap to år, Dokumentationsprojektet har løbet.

I seks af kommunerne er forvaltningsstrukturen ændret, typisk ved at man har reduceret ledelseslaget gennem sammenlægning af afdelinger eller enheder. For PPR gælder, at der i fire kommuner er sket ændringer, typisk ved at man er flyttet fra en forvaltning til en anden.

Skoleforvaltningerne har i fem af kommunerne ændret bemandingen på ledelsesniveau, mens PPR i seks kommuner har fået nye chefer. 
Det viser sig, ikke overraskende, at ændringer i forvaltningsstruktur og bemanding giver anledning til, at der er perioder - i værste fald på mere end et halvt år - hvor mange processer, herunder inklusionen, er på standby, mens organisationen finder "sine ben". 


\section{Konklusion}

Af Siddhartha Baviskar, Camilla Brorup Dyssegaard, Niels Egelund og Christopher de Montgomery

Regeringen har i foråret 2012 med bred tilslutning i Folketinget gennemført en ændring af folkeskoleloven, der afgrænser specialundervisning til at være undervisning i specialskoler og specialklasser samt undervisning i den almindelige folkeskole, hvor eleven får støtte i mindst ni ugentlige timer (12 ugentlige lektioner a $45 \mathrm{~min}$ ). Lovændringen giver kommunerne mulighed for større fleksibilitet i forbindelse med at tilrettelægge en inkluderende undervisning.

Regeringen og Kommunernes Landsforening har i "Aftale om kommunernes økonomi for 2013 (ØA13)" aftalt konkrete målsætninger for en succesfuld omstilling til inklusion. Målsætningerne omfatter andelen af elever, der inkluderes i den almindelige undervisning, det faglige niveau og elevernes trivsel.

Regeringen og kommunerne blev enige om følgende målsætninger:

- Andelen af elever, der skal inkluderes i den almindelige undervisning øges. Målet er således, at andelen af elever $i$ almindelig undervisning i 2015 er forøget fra 94,4 pct. til 96,0 pct. af det samlede elevtal i folkeskolen.

- Andelen af elever, der fär 2 eller derunder i læsning, retstavning og matematisk problemløsning $i$ 9. klasses afgangsprøve, skal være reduceret $i 2015 \mathrm{og}$ reduceres yderligere frem $\bmod 2018$.

- Elevernes trivsel fastholdes i takt med omstillingen til øget inklusion.

Denne rapports afsluttende, tværgående analyse af 12 kommuners omstilling til øget inklusion, det såkaldte Dokumentationsprojekt, som har løbet over årene 2013-2015, har til formål at se på, om målene er nået og videre at sammenholde de forskellige kommuners inklusionsindsats med målopfyldelsen nævnt i de tre punkter ovenfor. I vurderingen af målopfyldelsen indgår også resultater fra de nationale test og overgangsfrekvenser til ungdomsuddannelse. Den afsluttende, tværgående analyse har endvidere til formål at bidrage med viden om hvilke pædagogiske og styringsmæssige tilgange, som har den største effekt i forhold til målopfyldelse. Endelig skal den afsluttende analyses resultater ses i lyset af effektiv anvendelse af ressourcer. 


\section{Målopfyldelse}

Hvad angår inkludering i den almindelige undervisning er målet om en gennemsnitlig inklusionsprocent på 96 pct. nået for de tolv kommuner i undersøgelsen. Hvor andelen i 2010 var 93,1 pct., er den i 2015 på 96,0 pct. Der er en betydelig variation kommunerne imellem, om end den er blevet mindre over undersøgelsesperioden. I 2010 var de højeste og laveste andele henholdsvis 97,5 pct. og 89,5 pct. I 2015 er højeste og laveste andele på 98,2 pct. og 92,5 pct.

Vedrørende andelen af elever, der får 2 eller derunder i læsning og retstavning i 9. klasses afgangsprøve, ligger ti af de tolv kommuner i skoleårene 2012/2013 og 2013/2014 under 5 pct. Procentdelen med karakterer under 2 i dansk er vokset mellem 1. og 3. runde i alle kommuner undtagen én, hvor den er uændret. Når det gælder matematisk problemløsning, har udviklingen været mindre ensartet. Her er andelen faldet $\mathrm{i}$ otte kommuner, mens den er steget i tre kommuner. Samlet set er der tre kommuner, som ligger under 5 pct. over de tre skoleår. Den kommune, der har den højeste procentvise andel af elever, som får under 2 i matematisk problemløsning, ligger tæt på 12 pct. i alle tre skoleår. Det skal dog bemærkes, at inklusionsprocessen, der startede i efteråret 2012, kun i relativt beskeden grad kan have påvirket afgangsprøvekaraktererne i 2014, da det udelukkende vil være elever, der er inkluderet på 8. og 9. klassetrin, der kan have gået til afgangsprøve i 2014.

For resultaterne fra de nationale test gælder, at der er syv kommuner, der i perioden fra skoleåret 2012/2013 til 2013/2014 har opnået forbedrede resultater i dansk, sprogforståelse, mens fire kommuner har opnået forringede resultater. I dansk, afkodning, har syv kommuner opnået bedrede resultater, og fem kommuner har opnået forringede resultater. Ved dansk, tekstforståelse, er der seks kommuner med bedrede resultater og fem kommuner med forringede resultater. De klassetrin, der indgår i Dokumentationsprojektet, er ikke blevet testet $\mathrm{i}$ andre fag end dansk.

Data for overgangsfrekvenser til ungdomsuddannelse indsamlet $\mathrm{i}$ skoleåret 2014/2015 går tilbage til årgangen, der sluttede i folkeskolen i 2012, og kan derfor ikke kædes direkte sammen med inklusionsprocessen. Ser man tilbage på de tre foregående år, er der kun meget få bevægelser inden for de enkelte kommuner.

Trivselsmålinger blandt elever kan kun sammenlignes for seks af de tolv kommuner i perioden 2012/2013 til 2014/2015 på grund af manglende data. Trivselsniveauet er meget højt blandt eleverne, og der er ikke væsentlige ændringer i elevernes trivsel over de tre runder, og forældrenes svar følger stort set elevernes. 


\section{Pædagogiske og styringsmæssige tilgange}

Hvad angår pædagogiske og styringsmæssige tilgange er der defineret fem fokuspunkter, som undersøgelsen har skullet dække. Det er blevet undersøgt, hvilken indflydelse de fem fokuspunkter sammen med andre forhold har haft på opfyldelsen af målsætningerne.

De fem fokuspunkter, Dokumentationsprojektet har skullet dække, er:

- Inklusionsfremmende styringsmodeller

- Kompetencer

- Opbakning til inklusion

- Fastholdelse af elevernes trivsel

- Supplerende undervisning.

\section{Inklusionsfremmende styringsmodeller}

\section{$\varnothing$ konomiske incitamenter}

Der er i ti ud af de tolv kommuner etableret økonomiske incitamenter til inklusion. De økonomiske incitamenter virker med lidt forskellige takstsatser således, at skolerne forlods får tildelt økonomiske midler pr. elev, hvor beløb til supplerende undervisning og anden faglig støtte samt specialundervisning over ni timer om ugen er indregnet, og skolerne skal derefter betale et takstbeløb for hver elev, skolen henviser til en specialskole eller specialklasse. I enkelte kommuner er der dog en central pulje, skolen kan søge midler fra, og en sådan ordning er primært etableret for at sikre små skolers økonomiske grundlag.

Undersøgelsen har vist, at de økonomiske incitamenter til inklusion har været særdeles effektive til at fremme stigning $\mathrm{i}$ inklusionsprocenten på skolerne og $\mathrm{i}$ kommunerne. Der er dog samtidig en udfordring ved principperne om økonomiske incitamenter, idet udlægning af den totale økonomi til skolerne betyder, at princippet om, at "pengene følger eleverne", bliver mindre gennemskueligt, og især lærere og pædagoger, samt i en del tilfælde også forældre, føler ikke, at der er ekstra ressourcer. Problemet er accentueret af, at der i 2013 er seks kommuner og i 2014 fem kommuner, der har foretaget en generel reduktion af de samlede budgetter til folkeskolen. Når en skole får et reduceret budget, kan det let komme til at gå ud over antallet af støttetimer eller tolærertimer, og nogle skolechefer erkender, at man har givet med den ene hånd og taget med den anden. Nettodriftsudgifter pr. elev i faste priser er steget med gennemsnitligt 1,4 pct. fra 2012 til 
2014, men med en betydelig variation kommunerne imellem. Der er dog ingen entydig sammenhæng med inklusionsprocenten.

Alt i alt må det konstateres, at økonomiske incitamenter har været en af de stærkest motiverende faktorer for skolerne for ikke at udskille deres elever til segregerede foranstaltninger.

\section{Organisering af PPR}

I 2015 har samtlige tolv PPR-enheder gennemført ændringer i retning af, at de arbejder mere konsultativt. Der er også satset på efteruddannelse af PPR-medarbejdere, særligt i forhold til supervision. Der er også især inden for de seneste to år sket det, at PPR har fået en ny organisering, hvor man i flere kommuner har inddelt i distrikter, hvad der har medført, at medarbejderne er mere til stede på skolerne. Organiseringen i distrikter har også haft til formål at fremme det tværfaglige samarbejde og optimere sagsbehandlingen, så man hurtigere kan sætte ind over for børn med vanskeligheder, så det måske ikke når at blive til en "sag". Fokus er i meget høj grad på tidlig indsats og en samlet indsats over for familier.

Det kvantitative survey viser, at skolelederne vurderer samarbejdet med PPR som rigtig godt på samtlige indsatsområder: Rådgivning, vejledning, udredning af elever og supervision. Lærerne er dog lidt mere forbeholdne end skolelederne, men finder i øvrigt, at adgangen til rådgivning fra PPR er blevet lettere. I de kvalitative data nævnes også tydeligt, at det til tider kan være vanskeligt for lærerne at acceptere den konsultative arbejdsform. Lærerne kan opleve det frustrerende, at der ikke kan gives mere "præcise", konkrete råd i forhold til indsatser, der virker i undervisningen. Det er et andet centralt tema for PPR, at det over alle tre år nævnes, at der savnes medarbejdere fra PPR, som kan give en mere direkte, didaktisk vejledning til det pædagogiske personale.

I 2013 havde fem PPR-enheder ladet sig inspirere af KL's Pejlemærker og havde eller var ved at udarbejde ydelseskataloger, hvor de tilbød målrettede kurser for det pædagogiske personale i kommunen. I 2014 var antallet ni, men i 2015 er antallet, der arbejder med ydelseskataloger, reduceret til seks enheder. Dette forklarer lederne med, at L409 har gjort det meget vanskeligt at mødes med lærerne, samtidig med at skolereformen trækker mange ressourcer. Der opleves ikke at være overskud til nye tiltag. Endvidere beskriver PPR-lederne, at det ikke længere giver mening at arbejde med ydelseskataloger, da skolerne er i så massive forandringsprocesser, som skolereformen medfører. Ønsker til PPR varierer derfor meget fra skole til skole.

Det vurderes, at den konsultative indsats har haft en væsentlig, positiv virkning i forhold til at understøtte inklusion, da den medfører, at PPR-medarbejderne er fysisk til 
stede på skolerne, at udarbejdelsen af en pædagogisk-psykologisk vurdering ikke er den primære ydelse, som leveres, og at ventelister er væk.

\section{Visitationsprocessen}

For visitationsprocessen gælder generelt, som det fremgår af både de kvalitative og kvantitative analyser, at skoleledernes indflydelse er steget markant, hvad der er et resultat af, at ansvaret for brugen af ressourcer og arten af indsatser over for elever med særlige behov ligger hos skolelederen. En del PPR-ledere udtrykker en vis betænkelighed ved dette, da man kan være bekymret for, at økonomi prioriteres højere end elevernes pædagogiske behov, faglige udvikling og trivsel. Der er en forholdsvis høj grad af tilfredshed med tilbudsviften, fortrinsvis i de kommuner, hvor skole og PPR ligger i samme forvaltning, og der er også de fleste steder en samlet hensyntagen i forhold til befordring og fritidstilbud.

Revisitationsmønsteret i kommunerne er ikke væsentligt ændret, og man arbejder primært mod at begrænse nye henvisninger til specialtilbud. De kommuner, hvor man helt har nedlagt specialklasser, udgør naturligvis en undtagelse.

Undersøgelsens data tyder på, at visitationsprocessen har haft betydning for at øge inklusionsprocenten, men at det primært har en sammenhæng med den økonomiske incitamentsstruktur.

\section{Kompetencer}

\section{Kompetenceudvikling}

De kvalitative analyser har vist, at allerede i 2013 havde ni af kommunerne gjort en markant indsats med kompetenceudvikling på alle niveauer, og at det var sket tidligt i processen med at øge inklusionen. I en enkelt kommune var indsatsen inde i processen, og for to kommuner gjaldt, at man først kom i gang sent i 2013. De kvantitative data fra skolelederne viser, at andelen af skoler, der har holdt pædagogiske dage eller kurser, er faldet markant i 2014. Dette kan skyldes, at fokus har været et andet efter skolereformens ikrafttræden.

De kvantitative svar fra lærerne viser en stor modsætning til ledernes svar, som de kvantitative analyser ikke kan give forklaring på. Skolechefer og PPR-ledere er i 2015 blevet bedt om at forklare forholdet, og svarene dækker to temaer: indhold og kvalitet samt ønsker om yderligere kvalificering.

Med hensyn til indhold og kvalitet er der meget, som tyder på, at de kurser, der har været givet, i høj grad har været teoretisk orienterede. Der er også tegn på, at kursusudbuddet ikke har været finafstemt mellem top og bund, dvs. ikke er rettet mod, 
hvad lærerne selv mener, de har brug for. Det andet tema er, at der tilsyneladende er åbenlys efterspørgsel efter kompetenceudvikling i form af traditionelle kurser, og aktionslæring og supervision opleves ikke at være "rigtig" kompetenceudvikling.

Undersøgelsen peger alt $i$ alt på, at kompetenceudvikling har haft en vis indflydelse i forhold til at øge inklusionsprocenten, men at mange af de teoretisk orienterede kurser, der har været givet, ifølge skolechefer og PPR-ledere ikke har haft den ønskede transfereffekt i praksis, hvor aktionslæring skønnes at være mere effektiv, da lærerne er direkte involverede i processen.

\section{Brug af ressourcepersoner, pædagogiske metoder og PPR}

Alle tolv kommuner oplyser at have uddannet forskellige typer af ressourcepersoner til at fremme inklusionsprocessen. Skolelederne oplyser også i stort omfang, at der er forskellige former for ressourcer tilgængelige for lærerne, især AKT-vejledere, medarbejdere fra specialcenter/ressourcecenter, forskellige former for analysemodeller, fx LPmodellen, samt rådgivning fra PPR. Når lærerne er blevet stillet tilsvarende spørgsmål, er det især inklusionsvejleder, AKT-vejleder, medarbejder fra specialcenter/ressourcecenter og PPR, der omtales. Anvendelsen af specifikke pædagogiske modeller er faldende hen over perioden, især i 2014 - muligvis fordi de treårige implementeringsperioder er sluttet for mange af skolerne.

Hvis man spørger lærerne, i hvilken grad de anvender fx inklusionsvejledere, er resultatet påfaldende lavt i de første to undersøgelsesrunder, men dog med en signifikant stigning i sidste runde. Skolechefer og PPR-ledere er blevet bedt om at give en forklaring på det relativt lave niveau. Svarene placerer sig under to temaer: kulturkløft og kvalitet. Det første tema, kulturkløft, dækker, at det for mange lærere kræver en kulturændring at acceptere, at der er nogen, der er specialister, og at det også kan være vanskeligt at optræde i rollen som specialist. Det andet tema, kvalitet, går på vejlederens faglige og personlige kompetencer, der ikke altid er optimale.

Der er alt $\mathrm{i}$ alt klare tegn på, at ressourcepersoner er tilgængelige på de enkelte skoler og i kommunerne, men at det pædagogiske personale endnu ikke udnytter ressourcepersonerne optimalt, og at der derfor kun har været en beskeden virkning på inklusionsprocenten, men at der skønnes at være et stort uudnyttet potentiale.

\section{Opbakning til inklusion}

På politisk niveau har der været klar opbakning til inklusion i samtlige tolv kommuner, og der er udarbejdet overordnede målsætninger og strategier rettet mod skoler, lærere og forældre. I de fleste tilfælde er der også udarbejdet et omfattende skriftligt dokumen- 
tationsmateriale, særlige hjemmesider m.m., hvor man kan orientere sig, ligesom der har været afholdt informationsmøder for forældre og lærere, og sidstnævnte har også i meget stort omfang været tilbudt forskellige former for kompetenceudvikling. Skolebestyrelsesformændene har også i stort omfang taget ansvar for at give forældrene medejerskab.

Skolecheferne har i alle tre runder udtrykt stor opbakning til inklusion, PPRlederne bakker også op om inklusionsmålsætningen, men nogle er dog bekymrede for, om de tilbud, som de inkluderede elever får, er tilstrækkelige i forhold til at sikre deres fortsatte faglige og sociale udvikling. Hvad angår skolelederne, er der ganske betydelig opbakning, og den har været stort set uændret over de tre år. Til gengæld vurderer skolelederne, at lærerne kun i begrænset omfang bakker op om inklusion, og når lærerne selv svarer, angiver de endnu mindre opbakning. Skolechefer og PPR-ledere er blevet spurgt om dette, og hvad strategiske mål angår, falder svarene i to overordnede temaer: dels at der ved inklusion er tale om en top-down-beslutning, hvor der på lærerniveauet ikke er en tydelig forståelse af, hvad formålet og målsætningen for inklusion er, dels at der er tale om en betydelig frustration blandt lærerne, da de i det daglige arbejde står med udfordringerne med eleverne - og dertil kommer eftervirkningen af lockouten og arbejdet med at implementere skolereformen.

Såvel skolechefer som PPR-ledere i de tolv kommuner mener, at forældre generelt giver opbakning til inklusion, hvilket begrundes med, at der ikke har været en stigning i antallet af forældreklager, men der er samtidig en klar tendens til, at det er de inkluderede elevers forældre, som bakker mest op. Lærerne mener dog, at forældre kun i begrænset omfang bakker op om inklusion.

Alt i alt gælder, at opbakningen til inklusion er stor på det forvaltningsmæssige niveau, at den er lidt lavere på skolelederniveau og meget lavere på lærerniveau. Dette vurderes at have baggrund i, at der er tale om en top-down-beslutning, hvor der på lærerniveau samtidig er en betydelig frustration ved i det daglige at stå med problemerne oven i efterveerne af lockout og udfordringer med implementering af skolereformen.

\section{Fastholdelse af elevernes trivsel}

Der er indsamlet data fra elever ved hjælp af DCUM's trivselsbarometer. Af besvarelserne fremgår det, at langt de fleste elever i 2. klasse er glade for at gå i skole i almindelighed og for deres klasse i særdeleshed. Herudover angiver lagt de fleste elever også, at de har "mange" venner i klassen, og at de "for det meste" har nogen at lege med i frikvartererne. Eleverne i 2. klasse er desuden generelt meget glade for deres lærere. Set over de tre dataindsamlinger er gennemsnitsbesvarelsen på spørgsmålet om, hvorvidt eleverne er glade for deres klasse, faldet en anelse. 
Sammenligner vi med besvarelserne fra eleverne i 8 . klasse viser det sig, at disse elever generelt er mere glade for at gå i skole og mere glade for deres klasse end eleverne i 2. klasse. Eleverne i 8. klasse behandler også i højere grad hinanden godt i klassen. Tilsvarende har næsten alle eleverne i 8. klasse også "altid" eller "for det meste" nogen at være sammen med i frikvartererne. Omvendt er der dog lidt færre elever i 8. end i 2. klasse, som er glade for "alle" eller "de fleste" af deres lærere. Disse forskelle kan dog skyldes, at eleverne i anden klasse blev spurgt på en tretrinsskala, mens eleverne i 8. klasse blev spurgt på en femtrinsskala.

Generelt har 8. klassernes trivselsniveau ikke ændret sig det store siden runde 1, om end deres gennemsnit på spørgsmålet, om de er glade for at gå i skole, er faldet en anelse. Fraværet for eleverne i 8. klasse er faldet fra 1. til 3. runde.

Som et supplement til trivselsmålingen blandt eleverne i 2. og 8. klasse er det desuden undersøgt, hvordan elevernes forældre opfatter deres børns trivsel. Her viser analyserne helt generelt, at forældrene og elevernes svar på trivselsspørgsmålene i høj grad ligner hinanden. Forældrenes opfattelse af børnenes trivsel har ikke ændret sig nævneværdigt fra 1. til 3. runde.

Alt i alt må det konstateres, at der ikke er væsentlige ændringer i elevernes trivsel, og at forældrenes svar stort set ligner elevernes.

\section{Supplerende undervisning}

Der var i 2013 to kommuner, der havde en kommunal plan for supplerende undervisning og anden faglig støtte til enkeltelever, mens de ti andre kommuner lod det være op til skolernes ledelser - støttet af lokal ekspertise og i de fleste tilfælde PPR - at administrere den supplerende undervisning. I 2014 havde alle 12 kommuner valgt, at det er den enkelte skoleleder, der har ansvaret, idet der dog er en forventning om, at skolelederne modtager vejledning fra PPR og kommunens konsulenter.

Hvad angår tilrettelæggelsen af den supplerende undervisning, viser besvarelserne fra skolelederne, at det gennemsnitligt er en tredjedel af den supplerende undervisning, der er tilrettelagt som tolærertimer. Godt en tiendedel af den supplerende undervisning foregår med lærerassistenter, og en tredjedel anvendes i skolens ressourcecenter ved, at eleven tages ud af den almindelige undervisning. En fjerdedel af den supplerende undervisning er tilrettelagt på anden måde. Der er en vis variation over de tre undersøgelsesrunder, men de er ikke systematiske.

Der er stor spredning i antallet af elever på skolerne, der modtager supplerende undervisning, og der er dermed en meget forskellig praksis, også kommunerne imellem. Alt i alt må det konstateres, at den decentralisering af ansvar, der har fundet sted, sammen med ændringerne i reglerne for specialpædagogisk bistand har ført til, at praksis er 
blevet vidt forskellig, og at der ikke længere kan skabes et overblik over situationen for de elever, der har brug for mindre end ni timers ugentlig støtte.

\section{Fokuspunkter for arbejdet med inklusion og inklusionsindikatorer}

Der er i Dokumentationsprojektet forlods defineret syv inklusionsindikatorer: Startår for inklusionsprocessen, grad af fælles værdigrundlag på forvaltningsniveauet, grad af kompetenceudvikling, grad af økonomiske incitamenter, kvalitet af samarbejde mellem skoleforvaltning og PPR, ændring i inklusionsprocenten fra 2010 til 2013 og kommunens socioøkonomiske indeks.

I Dokumentationsprojektets afsluttende analyser er der set på sammenhænge mellem fokuspunkter og inklusionsindikatorer samt udviklingen over tid. Det gælder generelt, at der er relativt få sammenhænge, men de følgende er dog værd at bemærke:

Med hensyn til inklusionsfremmende styringsmodeller gælder, at i de kommuner, hvor inklusionsprocessen er startet tidligt, oplever skolelederne, at de har de største økonomiske incitamenter til inklusion. Der er også en sammenhæng mellem en tidlig start og tilgængeligheden og anvendelsen af inklusionsvejledere. Alt i alt gælder dermed meget naturligt, at jo tidligere man er startet, des længere er man kommet.

Hvis der er et lavt fælles værdigrundlag på forvaltningsniveauet, er skolelederne mere involverede i visitationsprocessen, ligesom de har et tættere samarbejde med PPR. I kommuner med en høj grad af kompetenceudvikling anvender lærerne i højere grad pædagogiske modeller, AKT-vejledere og sparring med medarbejdere fra skolens specialcenter.

I de kommuner, der har de største socialøkonomiske udfordringer, oplever skolelederne i mindre grad, at der foreligger strategier i kommunen i forhold til arbejdet med inklusion, og der holdes færre faste møder med PPR.

Skolebestyrelsesformændene i kommuner med de laveste socialøkonomiske udfordringer oplever i højere grad, at forældrene bakker op om målet om øget inklusion, og lærerne oplever også, at forældrene har kendskab til målsætningen.

Lærernes oplevelse af elevernes sociale trivsel er højest i kommuner, der startede inklusionsprocessen tidligt, har et højt fælles værdigrundlag, en høj grad af kompetenceudvikling og en lille ændring af inklusionsprocenten.

Der er foretaget undersøgelser af elevtrivsel med DCUM's trivselsbarometer. Det kan her konstateres, at der er en meget høj grad af trivsel hos eleverne, at de er glade for at gå i skole, at de er glade for deres kammerater og for deres lærere.

Set over tid må det konstateres, at der ikke er væsentlige ændringer i eleverne trivsel, og at forældrenes svar stort set ligner elevernes. Det må med hensyn til supplerende 
undervisning og anden faglig støtte konstateres, at den decentralisering af ansvar for ressourceforbrug og organisering, der har fundet sted, sammen med ændringerne i reglerne for specialpædagogisk bistand har ført til, at praksis er blevet vidt forskellig, og at der ikke længere kan skabes et overblik over situationen for de elever, der har brug for mindre end ni timers ugentlig støtte.

\section{Målsætninger}

Når man ser på andelen af elever, der får karakteren 2 eller derunder som samlet gennemsnit i læsning, retskrivning og matematisk problemløsning i 9. klasses afgangsprøve, ses en række statistiske sammenhænge i datamaterialet. Således forekommer en reduktion i andelen af elever med 2 eller derunder først og fremmest i kommuner med: En lav inklusionsprocent, et godt samarbejde mellem lærere og PPR, tilgængelighed af ressourcer til inklusion for lærere, forældre som udtrykker utilfredshed over inkluderede elever og høje udgifter pr. elev.

I forhold til et samlet godt resultat i den nationale præstationsprofil ved de nationale test i dansk (sprogforståelse, afkodning og tekstforståelse) ses sammenhænge i retning af, at gode resultater er forbundet med: En høj grad af kompetenceudvikling i forhold til inklusion, lærerne har deltaget i et stort antal aktiviteter i arbejdet med inklusion, lærerne har en positiv vurdering af kompetenceudviklingen og en høj grad af tilgængelige ressourcer.

I forhold til at opnå en høj procentdel, der er fortsat til en ungdomsuddannelse, er der følgende sammenhænge: At lærerne føler sig fagligt rustede til at håndtere inklusionsudfordringer, at lærerne bakker op om inklusionsmålsætningen, at forældrene bakker op om inklusionsmålsætningen, og at skolebestyrelsesformanden er tilfreds med skolens arbejde med elevernes trivsel.

I forhold til de afdækkede sammenhænge skal det bemærkes, at de elever, der har afsluttet 9. klasse i 2012, 2013 og 2014, vil have haft et relativt kortvarigt direkte udbytte af de initiativer, skolerne har sat i værk efter inklusionsprocessens start i skoleåret 2012/13. Det må derfor antages, at der er nogle underliggende sammenhænge mellem læreres, forældres og skolers generelle aktiviteter og lærernes, forældrenes og skolernes arbejde med inklusion. Disse generelle aktiviteter må så formodes at have indflydelse på hvor mange af skolernes elever, der umiddelbart går videre i en ungdomsuddannelse.

I forhold til at minimere procentdelen af elever, som lærerne ikke mener trives fagligt eller socialt, er der sammenhænge med: Lærerne føler sig fagligt rustede til at håndtere inklusionsudfordringer, lærerne bakker op om inklusionsmålsætningen, forældrene 
bakker op om inklusionsmålsætningen, samt at skolebestyrelsesformanden er tilfreds med skolens arbejde med elevernes trivsel.

Det fremgår her, at der er tale om nøjagtigt de samme sammenhænge, som der gjaldt for overgang til ungdomsuddannelse. Dette styrker antagelsen om, at der er nogle underliggende sammenhænge mellem læreres, forældres og skolernes generelle aktitivteter og lærernes, forældrenes og skolernes arbejde med inklusion - generelle aktiviteter, som formodes at have indflydelse på, at der er få af skolernes elever, der ikke trives fagligt og socialt.

\section{Forskelle mellem skolelederes og læreres svar}

I de kvantitative data har der over alle tre runder været iøjnefaldende forskelle mellem skoleledernes og lærernes svar på spørgsmål om overtagelse af de strategiske mål for inklusion, på graden og nytten af kompetenceudvikling samt oplevelse af tilstrækkelige kompetencer og på brug af inklusionsvejleder.

Skolechefer og PPR-ledere er blevet spurgt om dette, og hvad strategiske mål angår, falder svarene $\mathrm{i}$ to overordnede temaer: dels at der ved inklusion er tale om en topdown-beslutning, hvor der på lærerniveauet ikke er en tydelig forståelse af, hvad formålet og målsætningen for inklusion er, dels at der er tale om en betydelig frustration blandt lærerne, da de i det daglige arbejde står med udfordringerne med eleverne - og dertil kommer eftervirkningen af lockouten og arbejdet med at implementere skolereformen.

Hvad angår kompetenceudvikling dækker svarene to temaer: indhold og kvalitet samt ønsker om yderligere kvalificering. De kurser, lærerne har været på, har i meget høj grad været holdningsbearbejdende, mens lærerne efterspørger metoder eller teknikker, de kan bruge i det daglige. Der synes også at være tale om et snævert syn på, hvad kompetenceudvikling kan være. Det, som efterspørges, er i høj grad kurser, mens man nogle steder hellere har villet give aktionslæring. Endelig vil man sjældent opleve at have fået nok kompetenceudvikling, når man står med udfordringerne i den daglige undervisning.

For oplevelse af egne kompetencer er der tre temaer: afmagt, teamsamarbejde og tolærerordning. Afmagt dækker over, at lærerne synes, de mangler en "metodekasse", har vanskeligt ved at undervisningsdifferentiere og lede et undervisningsmiljø. Teamsamarbejde rummer det forhold, at en del lærere ikke formår at skabe et reelt teamsamarbejde. Tolærerordning dækker, at lærere er nervøse for ikke at slå til, og at de derfor ønsker "flere hænder". 
Ved brug af inklusionsvejleder er der to temaer: kulturkløft og vejlederkompetencer. Det kræver ifølge skolecheferne og PPR-lederne for mange lærere en kulturændring både i forhold til at få vejledere til at acceptere, at de har en ekspertrolle, og at få almenlærere til at gøre brug af de enkelte vejledere.

Der er også foretaget en kvantitativ analyse af forskelle mellem skoleleder- og lærersvar. Her peger analysen på, at fem faktorer har betydning for forskelle og ligheder mellem skoleledere og læreres syn på inklusionsmålsætning i samme skole. De skoler, hvor lærerne giver mindre opbakning til inklusionsmålsætningen end lederne, er kendetegnet ved følgende to forhold: Lærerne oplever i mindre grad end lederne, at de har et incitament til at inkludere elever med særlige undervisningsbehov, og lærerne oplever i mindre grad end lederne, at forældrene bakker op om inklusionsmålsætningen. Derimod kendetegner følgende tre forhold de skoler, hvor både skoleledere og lærere støtter inklusionsmålsætningen: Både skoleledere og lærere oplever, at der et godt samarbejde med PPR i forhold til rådgivning og vejledning, udredning af elever og supervision; både skoleledere og lærere oplever, at der er god adgang til inklusionsrelaterede ressourcer, fx inklusionsvejleder og AKT-vejleder, og lærerne oplever, at der er gode muligheder til at opbygge deres kompetencer $\mathrm{i}$ at fremme inklusion.

\section{Faktorer der fremmer og hæmmer inklusion}

De afsluttende kvalitative interview med skolechefer og PPR-ledere har givet mulighed for at foretage overordnede analyser, som identificerer inklusionsfremmende og inklusionshæmmende faktorer. Disse opstilles i punktform nedenfor, dels som en faktor, dels med en beskrivelse af hvad der ligger bag.

\begin{tabular}{|l|l|}
\hline Inklusionsfremmende faktorer & Beskrivelse \\
\hline Tilstedeværelse af fælles værdigrundlag & $\begin{array}{l}\text { Der skal være en fælles forståelse fra det } \\
\text { politiske niveau til det forvaltningsmæssi- } \\
\text { ge, skoleledelsesmæssige og praktiske ni- } \\
\text { veau }\end{array}$ \\
\hline Etablering af strategier for gennemførelse & $\begin{array}{l}\text { Når målsætningerne er etableret, er det } \\
\text { væsentligt, at det besluttes, hvordan der } \\
\text { kan arbejdes med processen }\end{array}$ \\
\hline Økonomiske incitamenter & $\begin{array}{l}\text { Det skal være således, at det er økonomisk } \\
\text { attraktivt for de enkelte skoler at undlade } \\
\text { at ekskludere elever }\end{array}$ \\
\hline
\end{tabular}




\begin{tabular}{|l|l|}
\hline PPR's ændrede funktion & $\begin{array}{l}\text { Tilgængelig PPR med gode muligheder for } \\
\text { at opnå rådgivning og supervision på de } \\
\text { enkelte skoler }\end{array}$ \\
\hline Teamsamarbejde & $\begin{array}{l}\text { Lærere, der har en forståelse af, hvad deres } \\
\text { teamsamarbejde kan bruges til, og er op- } \\
\text { mærksomme på den ressource, der er i } \\
\text { team }\end{array}$ \\
\hline
\end{tabular}

\begin{tabular}{|l|l|}
\hline Inklusionshæmmende faktorer & Beskrivelse \\
\hline For mange ændringer på én gang & $\begin{array}{l}\text { Omstilling til øget inklusion samtidig med } \\
\text { store ændringer som L409 og skolereform } \\
\text { gør det vanskeligt at bevare det overskud, } \\
\text { der skal til for at arbejde med ændrings- } \\
\text { processer }\end{array}$ \\
\hline Frontpersonalets afmægtighed & $\begin{array}{l}\text { Lærerne følte allerede inden inklusionen, } \\
\text { at de havde mange udfordrende elever, og } \\
\text { de føler ikke, at de har fået en tilstrækelig } \\
\text { viden om, hvilke metoder de kan bruge i } \\
\text { hverdagen med inkluderede elever }\end{array}$ \\
\hline Negativ medieomtale & $\begin{array}{l}\text { Det er svært for både skoleledere, persona- } \\
\text { le og forældre at se bort fra den negative } \\
\text { omtale, som inklusion har fået i medierne }\end{array}$ \\
\hline $\begin{array}{l}\text { Elever med udadreagerende adfærd ud- } \\
\text { fordrer }\end{array}$ & $\begin{array}{l}\text { Der mangler viden om og muligheder for, } \\
\text { at elever og lærere kan få aflastning, når } \\
\text { elever udviser udadreagerende adfærd i } \\
\text { klasserne }\end{array}$ \\
\hline $\begin{array}{l}\text { Endringer i forvaltningsstruktur og be- } \\
\text { manding }\end{array}$ & $\begin{array}{l}\text { Endringer i forvaltningsstruktur og be- } \\
\text { manding giver anledning til, at inklusion } \\
\text { og andre processer er på standby, mens } \\
\text { organisationen finder sit leje }\end{array}$ \\
\hline
\end{tabular}

\section{Alt i alt}

De tolv kommuner i undersøgelsen er lykkedes med som gennemsnit at nå inklusionsmålsætningen på 96 pct. i 2015, og det er vel at mærke sket inden for næsten samme beløbsramme pr. elev, hvad der peger på en effektiv anvendelse af ressourcer, som formentlig hænger sammen med decentralisering af ansvaret for brug af stort set samtlige 
ressourcer til den enkelte skole. Der er heller ikke sket væsentlige ændringer i andre elevers faglige udvikling og trivsel.

Det må konstateres, at økonomiske incitamenter har været en af de stærkest motiverende faktorer for skolerne for at mindske udskillelse af elever til segregerede foranstaltninger. Måderne, som kommunerne har grebet inklusionsprocessen an på, varierer overordentlig meget, og der er også store forskelle på, hvor langt de enkelte kommuner har ligget fra målet på 96 pct. og dermed de udfordringer, som kommunerne har stået overfor.

Alle PPR-enheder har ændret deres funktion, og det vurderes, at omstillingen i retning af at have en øget konsultativ funktion har haft en væsentlig, positiv virkning i forhold til at øge inklusionsprocenten. Ændringen har medført, at PPR-medarbejderne er fysisk til stede på skoler, således at PPR-medarbejderne er blevet mere tilgængelige i dagligdagen, og at udarbejdelsen af en pædagogisk-psykologisk vurdering ikke længere er den primære ydelse.

Undersøgelsens data tyder på, at kommunernes visitationsprocesser har haft betydning for at øge inklusionsprocenten, men at det primært har sammenhæng med den økonomiske incitamentsstruktur.

Meget peger i retning af, at kompetenceudvikling har haft en vis indflydelse i forhold til at øge inklusionsprocenten, men at mange af de teoretisk orienterede kurser, der har været givet, ikke har haft den ønskede transfereffekt i praksis.

Der er klare tegn på, at ressourcepersoner er tilgængelige på de enkelte skoler og i kommunerne, men at det pædagogiske personale endnu ikke udnytter ressourcepersonerne optimalt, og at der derfor kun har været en beskeden virkning på inklusionsprocenten, men at der skønnes at være et stort uudnyttet potentiale.

Opbakningen til inklusion er stor på det forvaltningsmæssige niveau, lidt lavere på skolelederniveau og meget lavere på lærerniveau. Dette vurderes at have baggrund i, at der er tale om en top-down-beslutning, hvor der på lærerniveau samtidig er en betydelig frustration ved i det daglige at stå med udfordringerne oven i efterveerne af lockout og med implementering af skolereformen.

Med hensyn til trivsel er niveauet meget højt blandt eleverne. Der er ikke væsentlige ændringer i elevernes trivsel over de tre runder, og forældrenes svar følger stort set elevernes.

Hvad angår supplerende undervisning, betyder den decentralisering af ansvar, der har fundet sted, sammen med ændringerne i reglerne for specialpædagogisk bistand, at praksis er blevet vidt forskellig, og at der ikke længere kan skabes et overblik over situationen for de elever, der har brug for mindre end ni timers ugentlig støtte. 
Samlende kan det siges, at undersøgelsen peger på, at økonomiske incitamenter i startfasen og en proces, som understøtter medejerskab på skolerne gennem etablering af inkluderende kulturer, strategier og praksis, der går fra ledelsen over personale til elever og forældre, tilgængelighed til PPR's medarbejdere, relevant kompetenceudvikling, rådighed over ressourcepersoner samt et teamsamarbejde er vigtige forudsætninger. 


\section{Referencer}

Baviskar, Siddhartha, Camilla Brørup Dyssegaard, Niels Egelund, Mette Lausten, Mikkel Lynggaard og Susan Tetler (2013): Kommunernes omstilling til øget inklusion pr. marts 2013. Institut for Uddannelse og Pædagogik, Aarhus universitet.

Baviskar, Siddhartha, Camilla Brørup Dyssegaard, Niels Egelund, Mette Lausten og Mikkel Lynggaard (2014): Kommunernes omstilling til øget inklusion pr. marts 2014. Institut for Uddannelse og Pædagogik, Aarhus universitet

Beuchert, Louise Voldby, og Anne Brink Nandrup (2014): The Danish National Tests-A Practical Guide. No. 2014-25.

Danmarks Evalueringsinstitut (2011): Indsatser for inklusion i folkeskolen.

Deloitte (2010): Specialundervisning i folkeskolen - veje til en bedre organisering og styring. KL, Undervisningsministeriet og Finansministeriet. Juli 2010.

Dyssegaard, Camilla Brørup, og Michael Søgaard Larsen (2013): Viden om inklusion. Dansk Clearinghouse for uddannelsesforskning, Institut for Uddannelse og Pædagogik, Aarhus Universitet.

Kommunernes Landsforening (2011): Mere inklusion med bedre styring: Vejledning til styring af specialundervisningsområdet mod mere inklusion.

KREVI (2011): Ekskluderende specialundervisning. Hvem fär det, og hoilke forskelle er der mellem kommunerne? Århus. November 2011.

Sløk, Camilla Karen Balle, Mathilde Hjerrild Carlsen og Niels Erik Hulgård Larsen (2011): Hvad skal barnet hedde? - Rapport om ledelse af inklusion. København: Copenhagen Business School og Professionshøjskolen UCC. 


